ORP-56296

Revision 0

\title{
Final Report - Glass Formulation Development and DM10 Melter Testing with ORP LAW Glasses, VSL-09R1510-2, Rev. 0, dated 6/12/09
}

Prepared for the U.S. Department of Energy

Assistant Secretary for Environmental Management

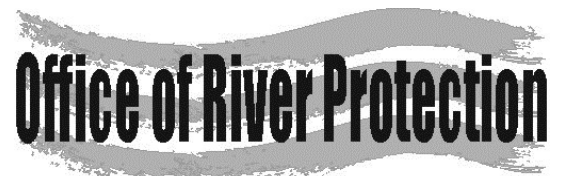

P.O. Box 450

Richland, Washington 99352 
ORP-56296

Revision 0

\section{Final Report - Glass Formulation Development and DM10 Melter Testing with ORP LAW Glasses, VSL-09R1510-2, Rev. 0, dated $6 / 12 / 09$}

\author{
A. A. Kruger \\ Department of Energy - Office of River Protection \\ I. L. Pegg \\ The Catholic University of America \\ K. S. Matlack \\ The Catholic University of America
}

\author{
I. Joseph \\ The Catholic University of America \\ I. S. Muller \\ The Catholic University of America \\ W. Gong \\ The Catholic University of America
}

Prepared for the U.S. Department of Energy

Assistant Secretary for Environmental Management

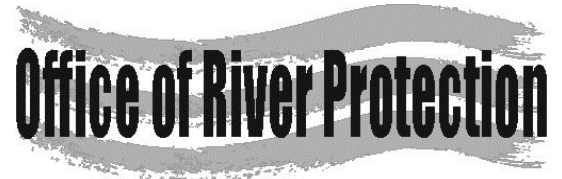

P.O. Box 450

Richland, Washington 99352

\section{APPROVED}

By Shauna Adams at 10:56 am, Nov 13, 2013 
ORP-56296

Revision 0

TRADEMARK DISCLAIMER

Reference herein to any specific commercial product, process, or service by tradename, trademark, manufacturer, or otherwise, does not necessarily constitute or imply its endorsement, recommendation, or favoring by the United States Government or any agency thereof or its contractors or subcontractors.

This report has been reproduced from the best available copy.

Printed in the United States of America 


\section{Final Report}

Glass Formulation Development and DM10 Melter Testing with ORP LAW Glasses

prepared by

Keith S. Matlack, Innocent Joseph, Weiliang Gong, Isabelle S. Muller, and Ian L. Pegg

Vitreous State Laboratory

The Catholic University of America

Washington, DC 20064

for

EnergySolutions

and

Department of Energy

Office of River Protection

April 2, 2009

Rev. 0; 6/12/09 
Document Title: Glass Formulation Development and DM10 Melter Testing with ORP LAW Glasses

Document Number

and Revision:

Issue Date:

Perfor ming Organization: Vitreous State Laboratory, The Catholic University of America

Test Plan:
LAW Glass Formulation Development and Testing, VSL-08T1510-1, Rev. 0

This report describes the results of testing specified by the above Test Plan. The work was performed in compliance with the quality assurance requirements specified in the Test Plan Results required by the Test Plan are reported. The test results and this report have been reviewed for correctness, technical adequacy, completeness, and accuracy.

I.L. Pegg:

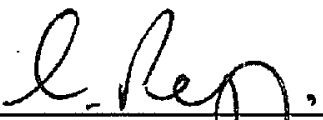

VSL Program Director/Principal Inyestigator

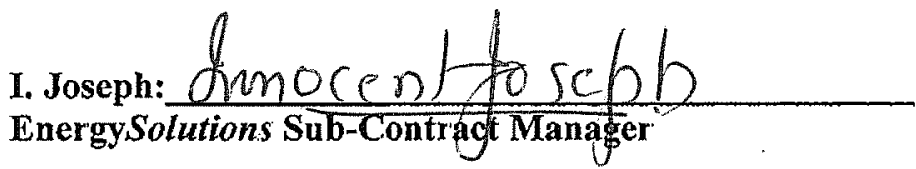

Date: $6 / 15 / 09$

Date: $6 / 15 / 09$ 
The Catholic University of America Vitreous State Laboratory
Glass Formulation Development and DM10 Melter Testing with ORP LAW Glasses Final Report, VSL-09R1510-2, Rev. 0

\section{TABLE OF CONTENTS}

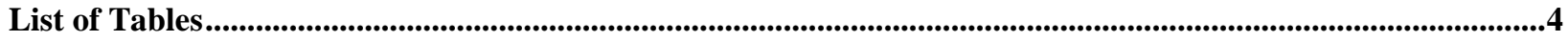

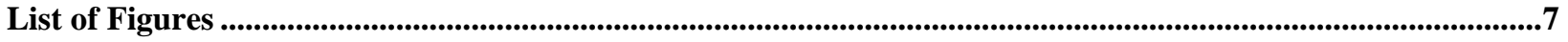

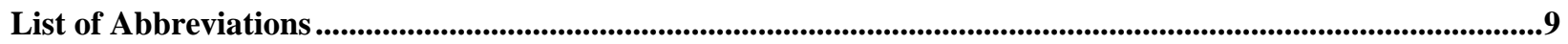

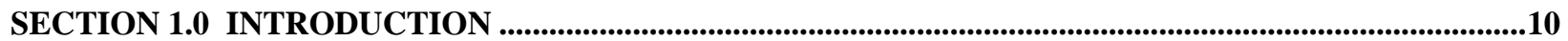

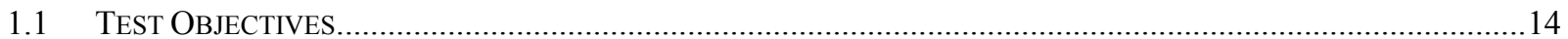

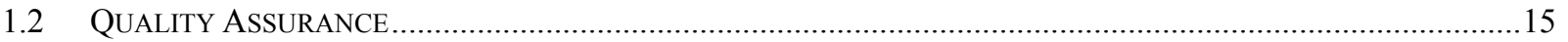

SECTION 2.0 WASTE SIMULANTS, GLASS FORMULATIONS AND FEED ANALYSIS ............................16

2.1 REgION A (ORPLA) WASTE SiMULANT AND GLASS FormULATION........................................................17

2.1.1 Region A (ORPLA) Waste Simulant for Tank AN-105 .........................................................................17

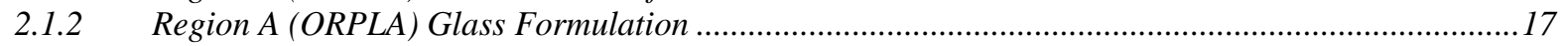

2.2 REGION D (ORPLD) WASTE SIMULANT AND GLASS FoRMULATION...........................................................

2.2.1 Region D (ORPLD) Waste Simulant for Tank AN-102 ...............................................................21

2.2.2 Region D (ORPLD) Glass Formulation.....................................................................................22

2.3 REGION F (ORPLF) WASTE SIMULANT AND GLASS FORMULATION ...........................................................22

2.3.1 Region F (ORPLF) Waste Simulant for Tank AZ-102 ..............................................................23

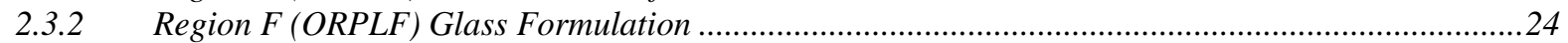

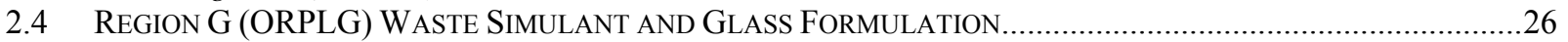

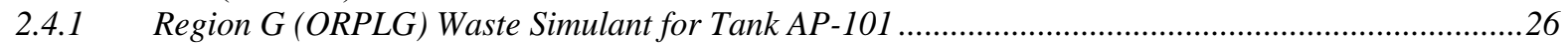

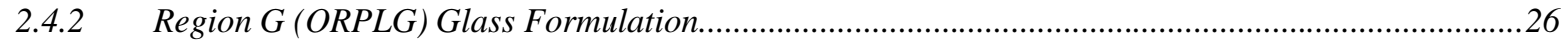

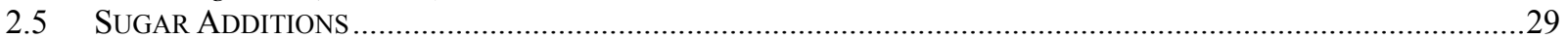

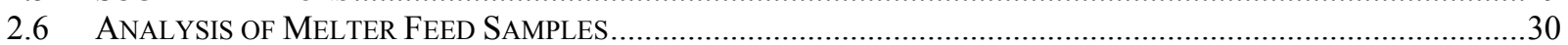

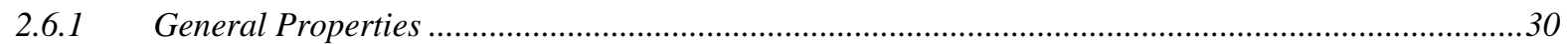

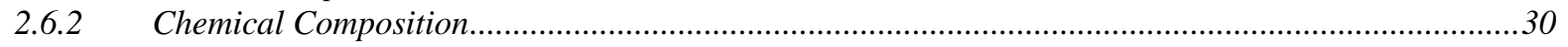

SECTION 3.0 DM10 TESTS ....................................................................................................................................32

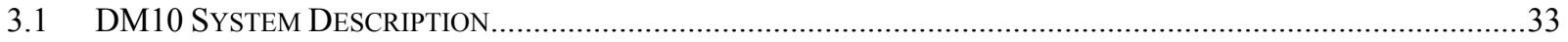

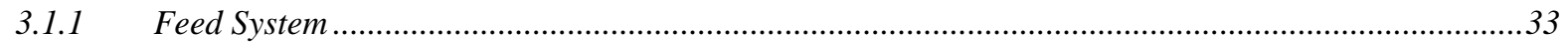

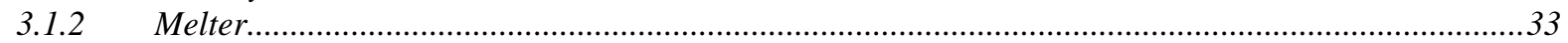

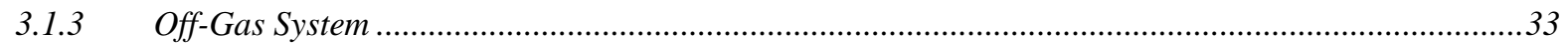

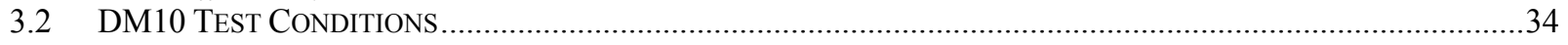

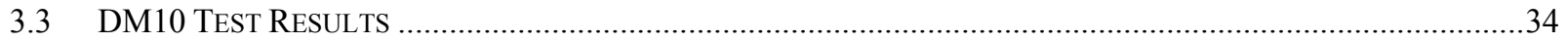

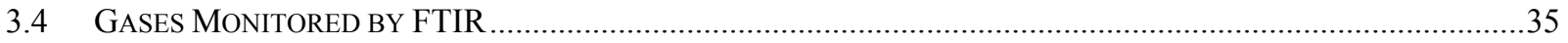

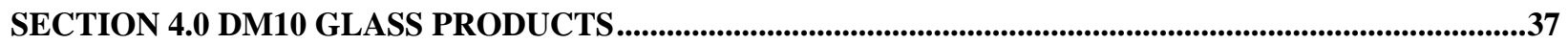

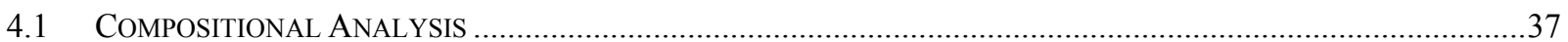

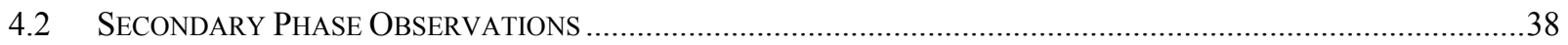

4.3 Comparison OF THE Properties of Crucible AND MElter GlaSSES ......................................................39

SECTION 5.0 SUMMARY AND CONCLUSIONS ...................................................................................................41

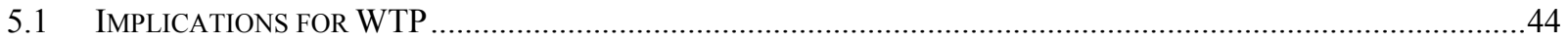

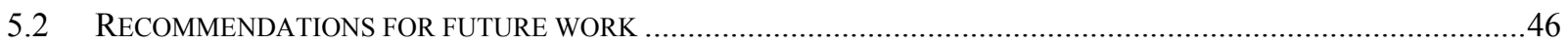

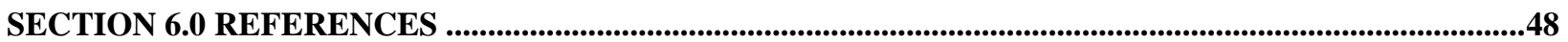




\section{List of Tables}

Table 1.1. Waste Compositions and Corresponding Target Concentrations in Glass.

Table 2.1. LAW Sub-Envelope A1 for AN-105 Waste Simulant Recipe at Nominal 8 Molar Sodium.

$\underline{\text { Page }}$

Table 2.2.

Target and Analyzed Compositions (wt \%) of Eight ORPLA Crucible Glasses.

Table 2.3. Descriptions of Eight As-Melted and Heat Treated ORPLA Crucible Glasses.

Table 2.4 . Measured Sulfate Solubility Limits in Eight ORPLA Glasses.

\section{$\mathrm{T}-1$}

$\mathrm{T}-2$

$\mathrm{T}-3$

$\mathrm{T}-5$

Table 2.5. Results of 7-day PCT (at $90^{\circ} \mathrm{C}$ ) and VHT (at $200^{\circ} \mathrm{C}$ for 24 Days) for Eight ORPLA Crucible Glasses.

T-6

Table 2.6.

Table 2.7. Viscosities and Electrical Conductivities of Three ORPLA Crucible Glasses

Table 2.9. Oxide Composition of AN-105 Simulant and ORPLA20 Glass Composition Used in Melter Tests (wt \%).

Table 2.10a. Glass Former Additives for 1 Liter of AN-105 Simulant (8 M Na) and Corresponding Melter Feed Properties.

Table 2.10b. $\mathrm{NaOH}$ and $\mathrm{Na}_{2} \mathrm{SO}_{4}$ Additions Required to Obtain $24 \mathrm{wt} \% \mathrm{Na}_{2} \mathrm{O}$ and Various $\mathrm{SO}_{3}$ Concentrations in the ORPLA20 Glass.

Table 2.11. LAW Sub-Envelope C2 (AN-102) Simulant Recipe at 8 Molar Sodium.

Table 2.16. Viscosities and Electrical Conductivities of Six ORPLD Crucible Glasses

Table 2.17. Results of K-3 Corrosion Testing for Four ORPLD Crucible Glasses.

Table 2.18. Summary of Test Results for Selected ORPLD Glass Formulation ORPLD6 and Comparison to ILAW Requirements.

$\mathrm{T}-17$

Table 2.19. Oxide Composition of AN-102 Simulant and ORPLD6 Glass Composition Used in Melter Tests (wt\%).

Table 2.20a. Glass Former Additives for 1 Liter of AN-102 Simulant (8 M Na) and Corresponding Melter Feed Properties.

Table 2.20b. $\mathrm{NaOH}$ and $\mathrm{Na}_{2} \mathrm{SO}_{4}$ Additions Required to Obtain $22 \mathrm{wt} \% \mathrm{Na}_{2} \mathrm{O}$ and Various $\mathrm{SO}_{3}$ Concentrations in the ORPLD6 Glass.

Table 2.21. LAW Sub-Envelope B2 (AZ-102) Waste Simulant Recipe at 5.5 Molar Sodium.

Table 2.22. Target and Analyzed Compositions (wt\%) of Fourteen ORPLF Crucible Glasses.

Table 2.23. Descriptions of Fourteen As-Melted and Heat Treated ORPLF Crucible Glasses.

Table 2.26 Fourteen ORPLF Crucible Glasses. 
Table 2.27. Results of K-3 Corrosion Testing for Ten ORPLF Crucible Glasses.

$\mathrm{T}-28$

Table 2.28. Summary of Test Results for Selected ORPLF Glass Formulation ORPLF7 and Comparison to ILAW Requirements.

Table 2.29. Oxide Composition of AZ-102 Simulant and ORPLF7 Glass Composition Used in Melter Tests (wt\%).

Table 2.30a. Glass Former Additives for 1 Liter of LAW AZ-102 Simulant (5.5 M Na) and Corresponding Melter Feed Properties.

Table 2.30b. $\mathrm{NaOH}$ and $\mathrm{Na}_{2} \mathrm{SO}_{4}$ Additions Required to Obtain $12 \mathrm{wt} \% \mathrm{Na}_{2} \mathrm{O}$ and Various $\mathrm{SO}_{3}$ Concentrations in the ORPLF7 Glass.

Table 2.31. LAW Sub-Envelope A2 (AP-101) Waste Simulant Recipe at 8.45 Molar Sodium.

Table 2.32. Target and Analyzed Compositions (wt\%) of Twelve ORPLG Crucible Glasses.

Table 2.33. Descriptions of Twelve As-Melted and Heat Treated ORPLG Crucible Glasses.

Table 2.34. Measured Sulfate Solubility Limits in Twelve ORPLG Crucible Glasses.

Table 2.35. Results of 7-day PCT (at $90^{\circ} \mathrm{C}$ ) and VHT (at $200^{\circ} \mathrm{C}$ for 24 Days) for Twelve ORPLG Crucible Glasses.

Table 2.36. Viscosities and Electrical Conductivities of Eleven ORPLG Crucible Glasses.

Table 2.37. Results of K-3 Corrosion Testing for Eight ORPLG Crucible Glasses.

Table 2.38. Summary of Test Results for Selected ORPLG Glass Formulation ORPLG9 and Comparison to ILAW Requirements.

Table 2.39. Oxide Composition of AP-101 Simulant and ORPLG9 Glass Composition Used in Melter Tests (wt\%).

Table 2.40a. Glass Former Additives for 1 Liter of AP-101 Simulant (8.45 M Na) and Corresponding Melter Feed Properties.

Table 2.40b. $\mathrm{NaOH}$ and $\mathrm{Na}_{2} \mathrm{SO}_{4}$ Additions Required to Obtain $21.0 \mathrm{wt} \% \mathrm{Na}_{2} \mathrm{O}$ and Various $\mathrm{SO}_{3}$ Concentrations in the ORPLG9 Glass.

Table 2.41. Characteristics of Melter Feed Samples During DM10 ORP LAW Tests.

Table 2.42. Target and XRF Analyzed Composition of Vitrified Melter Feed Samples (wt\%).

Table 3.1. Summary of Test A (Simulant: ORP S8AN105, Glass Formulation: ORPLA20) Conditions and Results.

$\mathrm{T}-30$

$\mathrm{T}-31$

$\mathrm{T}-31$

$\mathrm{T}-32$

$\mathrm{T}-33$

$\mathrm{T}-35$

$\mathrm{T}-36$

$\mathrm{T}-37$

$\mathrm{T}-38$

$\mathrm{T}-39$

$\mathrm{T}-40$

$\mathrm{T}-41$

$\mathrm{T}-42$

$\mathrm{T}-42$

$\mathrm{T}-43$

$\mathrm{T}-44$

$\mathrm{T}-47$

Table 3.2. Summary of Test D (Simulant: ORP S8AN102, Glass Formulation: ORPLD6) Conditions and Results.

$\mathrm{T}-48$

Table 3.3. $\quad$ Summary of Test F (Simulant: ORP S5AZ102, Glass Formulation: ORPLF7) Conditions and Results.

Table 3.4. Summary of Test G (Simulant: ORP S8AP101, Glass Formulation: ORPLG9) Conditions and Results.

Table 4.1. Listing of DM10 Glasses Discharged, Masses, Target Sulfur Contents and Analysis Performed.

Table 4.2. XRF Analyzed Compositions for DM10 Discharged Glass Samples (wt\%).

Table 4.3. Comparison of Discharged Glass XRF Analysis and Target Compositions (wt\%).

Table 4.4. $\quad \mathrm{XRF}$ and DCP Analyzed Compositions for Selected Discharged Glass Samples During DM10 ORP LAW Tests (wt\%).

Table 4.5. Listing of Dip Samples and Presence of Sulfate Layer During DM10 Melter Tests. 
Table 4.6. Results of PCT Leaching Procedure (ASTM C1285, 7-days at $90^{\circ} \mathrm{C}$, Stainless Steel Vessel; $\mathrm{S} / \mathrm{V}=2000 \mathrm{~m}^{-1}$ ) for Crucible Glass and Corresponding Melter Glass Samples from DM10 ORP LAW Tests.

Table 4.7. VHT Results (24 Day) for Crucible Glass and Corresponding Melter Glass Samples that Contain the Maximum Sulfur ConcentrationWithout Formation of Secondary Phases During DM10 ORP LAW Tests.

Table 5.1. Maximum Sodium and Sulfur Oxide Concentrations Achieved in Crucible and Melter Tests (wt $\%$ in Glass).

Table 5.2 Waste Loading Improvements in LAW Glass Formulations Developed for WTP and ORP. 


\section{List of Figures}

Figure 2.1. Sulfate solubility determined by remelting with excess $\mathrm{SO}_{3}$ for forty one new ORP LAW crucible glasses.

F-1

F-2

Figure 2.2.

VHT results for forty one new ORP LAW crucible glasses.

F-3

Figure 2.4.

Normalized PCT releases for forty one new ORP LAW crucible glasses.

K-3 corrosion results for thirty eight new ORP LAW crucible glasses and four previous formulations.

F-4

Figure 2.5

Figure 2.6.

Rheology of ORLPF feed at 5 Molar sodium; WTP upper bound is also shown. F-5 Results of $\mathrm{SO}_{2} / \mathrm{O}_{2}$ gas bubbling tests on the new ORP LAW glass ORPLG9 at the nominal $\mathrm{Cr}_{2} \mathrm{O}_{3}$ content of $0.5 \mathrm{wt} \%$ and at $1 \mathrm{wt} \% \mathrm{Cr}_{2} \mathrm{O}_{3}$ and the previous ORP Envelope A glasses LAWA161 and LAWA187 at $1150^{\circ} \mathrm{C}$.

F-6

Figure 3.1.a. Representative plot of glass pool temperatures during DM10 tests.

This plot is from the first test performed (Test A).

F-7

Figure 3.1.b. Representative plot of glass pool temperatures during DM10 tests.

This plot is from the last full test performed (Test G).

F-8

Figure 3.2.a. Representative plot of plenum temperatures during DM10 tests.

This plot is from the first test performed (Test A).

F-9

Figure 3.2.b. Representative plot of plenum temperatures during DM10 tests.

This plot is from the last full test performed (Test G).

F-10

F-11

F-12

F-13

F-14

F-15

F-16

F-17

F-18

Figure 4.1.d.

Figure 4.2.a.

Figure 4.2.b.

Figure 4.2.c.

Figure 4.2.d.

Figure 4.3.a.

Figure 4.3.b.

Figure 4.3.c.

Figure 4.3.d.

Figure 4.4.a.

Figure 4.4.b.

XRF analysis of sodium and silica in DM10 product glasses from Test D.

$\mathrm{XRF}$ analysis of sodium and silica in DM10 product glasses from Test F.

$\mathrm{XRF}$ analysis of sodium and silicon in DM10 product glasses from Test G.

XRF analysis of aluminum and calcium in DM10 product glasses from Test A.

XRF analysis of aluminum and calcium in DM10 product glasses from Test D.

XRF analysis of aluminum and calcium in DM10 product glasses from Test F.

F-19

F-20

F-21

XRF analysis of aluminum and calcium in DM10 product glasses from Test G. F-22

$\mathrm{XRF}$ analysis of zinc and zirconium in DM10 product glasses from Test A.

XRF analysis of zinc and zirconium in DM10 product glasses from Test D.

$\mathrm{F}-23$

F-24

$\mathrm{XRF}$ analysis of zinc and zirconium in DM10 product glasses from Test F.

$\mathrm{XRF}$ analysis of zinc and zirconium in DM10 product glasses from Test G.

$\mathrm{XRF}$ analysis of potassium and magnesium in DM10 product glasses from Test A.

$\mathrm{F}-25$

F-26

F-27

F-28

Test D.

Figure 4.4.c. XRF analysis of potassium and magnesium in DM10 product glasses from Test F. 
Figure 4.5.d. XRF analysis of chromium in DM10 product glasses from Test G. $\quad$ F-34

Figure 4.6.a. XRF analysis of tin in DM10 product glasses from Test A. $\quad$ F-35

Figure 4.6.b. XRF analysis of tin in DM10 product glasses from Test G. $\quad$ F-36

Figure 4.7.a. $\quad$ XRF analysis of vanadium in DM10 product glasses from Test D. $\quad$ F-37

Figure 4.7.b. $\quad$ XRF analysis of vanadium in DM10 product glasses from Test F. $\quad$ F-38

Figure 4.8.a. $\quad$ XRF analysis of chlorine in DM10 product glasses from Test A. $\quad$ F-39

Figure 4.8.b. $\quad$ XRF analysis of chlorine in DM10 product glasses from Test D. $\quad$ F-40

Figure 4.8.c. $\quad$ XRF analysis of chlorine in DM10 product glasses from Test G. $\quad$ F-41

Figure 4.9. Secondary sulfur phases on dip sample Z10-D-10C from the end of Test A4. F-42

Figure 4.10. Secondary sulfur phases on dip sample Z10-D-53A from the end of Test D3 F-43

Figure 4.11. Secondary sulfur phases on dip sample Z10-D-90E from the end of Test D2. F-44

Figure 4.12. Comparison of PCT results for ORP crucible and melter glasses.

Figure 4.13. Comparison of VHT coupons for glass formulation ORPLA20. $\quad$ F-46

Figure 4.14. Comparison of VHT coupons for glass formulation ORPLD6. $\quad$ F-47

Figure 4.15. Comparison of VHT coupons for glass formulation ORPLF7. $\quad$ F-48

Figure 4.16. Comparison of VHT coupons for glass formulation ORPLG9. F-49

Figure 4.17. ORP LAW melter glass densities: comparison of glass as-collected from the $\begin{array}{ll}\text { DM10 melter and after remelting. } & \text { F-50 }\end{array}$

Figure 5.1. Overview of $\mathrm{Na}_{2} \mathrm{O}$ and $\mathrm{SO}_{3}$ loadings for WTP and ORP glasses. F-51

Figure 5.2 Evolution of $\mathrm{Cr}_{2} \mathrm{O}_{3}$ content (XRF wt\%) in the glasses collected from DM-10 testing.

F-52 


\section{List of Abbreviations}

$\begin{array}{ll}\text { AA } & \text { Atomic Absorption Spectroscopy } \\ \text { ANL-LRM } & \text { Argonne National Laboratory - Low-Activity Waste Reference Material } \\ \text { CCC } & \text { Canister Centerline Cooling } \\ \text { CUA } & \text { Catholic University of America } \\ \text { DCP-AES } & \text { Direct Current Plasma - Atomic Emission Spectroscopy } \\ \text { DM } & \text { DuraMelter } \\ \text { DOE } & \text { Department of Energy } \\ \text { EDS } & \text { Energy Dispersive X-ray Spectroscopy } \\ \text { FTIR } & \text { Fourier Transform Infrared Spectroscopy } \\ \text { GFC } & \text { Glass Forming Chemical } \\ \text { HEPA } & \text { High-Efficiency Particulate Air Filter } \\ \text { HLW } & \text { High Level Waste } \\ \text { IC } & \text { Ion Chromatography } \\ \text { IHLW } & \text { Immobilized High Level Waste } \\ \text { ILAW } & \text { Immobilized Low Activity Waste } \\ \text { LAW } & \text { Low Activity Waste } \\ \text { M } & \text { Molarity } \\ \text { NQA } & \text { Nuclear Quality Assurance } \\ \text { ORP } & \text { Office of River Protection } \\ \text { PCT } & \text { Product Consistency Test } \\ \text { QA } & \text { Quality Assurance } \\ \text { QAPP } & \text { Quality Assurance Project Plan } \\ \text { QC } & \text { Quality Control } \\ \text { RPP } & \text { River Protection Project } \\ \text { SEM } & \text { Scanning Electron Microscope } \\ \text { SOP } & \text { Standard Operating Procedure } \\ \text { TFCOUP } & \text { Tank Farm Contractor Operation and Utilization Plan } \\ \text { VHT } & \text { Vapor Hydration Test } \\ \text { VSL } & \text { Vitreous State Laboratory } \\ \text { WTP } & \text { Hanford Tank Waste Treatment and Immobilization Plant } \\ \text { XRF } & \text { X-Ray Fluorescence Spectroscopy } \\ \end{array}$




\section{SECTION 1.0 INTRODUCTION}

About 50 million gallons of high-level mixed waste is currently stored in underground tanks at The United States Department of Energy's (DOE's) Hanford site in the State of Washington. The Hanford Tank Waste Treatment and Immobilization Plant (WTP) will provide DOE's Office of River Protection (ORP) with a means of treating this waste by vitrification for subsequent disposal. The tank waste will be separated into low- and high-activity waste fractions, which will then be vitrified respectively into Immobilized Low Activity Waste (ILAW) and Immobilized High Level Waste (IHLW) products. The ILAW product will be disposed in an engineered facility on the Hanford site while the IHLW product will be directed to the national deep geological disposal facility for high-level nuclear waste. The ILAW and IHLW products must meet a variety of requirements with respect to protection of the environment before they can be accepted for disposal.

The Office of River Protection is currently examining options to optimize the Low Activity Waste (LAW) Facility and LAW glass waste form. One option under evaluation is to enhance the waste processing rate of the vitrification plant currently under construction. It is likely that the capacity of the LAW vitrification plant can be increased incrementally by implementation of a variety of low-risk, high-probability changes, either separately or in combination. These changes include:

- Operating at the higher processing rates demonstrated at the LAW pilot melter

- Increasing the glass pool surface area within the existing external melter envelope

- Increasing plant availability

- Increasing the glass waste loading

- Operating the melter at a slightly higher temperature

The Vitreous State Laboratory (VSL) at The Catholic University of America (CUA) and EnergySolutions, Inc. have evaluated several of these potential incremental improvements for ORP in support of its evaluation of WTP LAW facility optimization [1]. Some of these incremental improvements have been tested at VSL including increasing the waste loading, increasing the processing temperature, and increasing the fraction of the sulfur in the feed that is partitioned to the off-gas stream (assuming that the present WTP recycle loop can be broken) [24]. These approaches successfully demonstrated increases in glass production rates and significant increases in sulfate incorporation and, therefore, waste loadings. This testing also demonstrated production rate increases and sulfur retention in the glass product at slightly higher than nominal glass processing temperatures. Subsequent tests demonstrated further enhancement of glass formulations for all of the LAW waste envelopes, increasing waste loading in the glass product and thereby reducing the amount of glass to be produced by the WTP for the same amount of waste processed [5,6]. The main objective of the next phase of testing [7] was to determine the applicability of these improvements over the expected range of sodium and sulfur 
concentrations for Hanford LAW. Five high waste loading glass formulations spanning the range of expected $\mathrm{Na}_{2} \mathrm{O}$ and $\mathrm{SO}_{3}$ concentrations in the Hanford LAW glasses were developed and subjected to melter testing. Glass formulation development and melter testing were designed such that the maximum achievable waste loadings could be determined.

For a large number of Hanford LAW streams, sulfur is the main component that limits waste loading in glass. However, for some LAW Envelope A streams with low sulfate contents, the alkali concentration becomes the waste loading limiting factor. In general, waste loading is limited by sulfur for wastes with a high sulfur-to-sodium ratio, while those with a low sulfur-tosodium ratio are limited by sodium (or more specifically, total alkali (sodium plus potassium)). Minimizing overall glass volume across the entire LAW inventory, which is clearly of economic benefit, therefore, entails addressing both the sulfur limitation and the alkali limitation, depending on the waste type.

While processing melter feeds with very high sulfate concentrations, a molten sulfate salt phase forms in the cold-cap region during processing. This phase may exist as transient droplets or be sufficiently extensive to produce a separate salt phase that becomes mechanically disengaged from the rest of the cold cap. Once formed, the salt phase is slow to dissolve into the underlying glass melt; consequently, the salt phase typically forms before the underlying glass melt is saturated with sulfate [8-11]. If the feed rate is sufficiently low (which is clearly undesirable), the equilibrium sulfate saturation concentration in the glass can be approached more closely before a separate salt phase forms. However, in general, as the feed rate is increased, for the same sulfate concentration in the feed, the salt phase appears progressively earlier. Thus, in practice, the formation of a sulfate phase is governed by both thermodynamic and kinetic factors and, therefore, the effects of both must be considered in order to avoid the formation of such phases during operations. The presence of the corrosive, low-melting, electrically conductive salt phase is undesirable from the perspectives of melter operation, melter lifetime, safety, and product quality. Accordingly, the WTP plans to control the composition of the LAW melter feed such that formation of a separate salt phase is avoided. Clearly, the control bounds that are imposed will determine the achievable waste loading limits and, therefore, will determine the waste processing rate for a given glass production rate (i.e., melter capacity).

For waste with low sulfur-to-sodium ratio, waste loading is instead limited by the total alkali content in the glass. At high alkali contents, glass leach resistance (PCT and VHT) decreases and the refractory corrosion rate in the glass melt increases. In addition, the melt viscosity may become too low and the electrical conductivity may become too high. Typically, however, the product leach resistance and the refractory corrosion properties are the first to be compromised as the alkali content in the glass is increased. Accordingly, the present work addresses LAW streams spanning a range of sulfur-to-sodium ratios with the objective of determining the maximum achievable waste loadings across this range, from sodium-limited to, sodium + potassium limited to, sulfur-limited formulations. As noted above, the broader intent is to develop a basis for estimation of the potential maximum waste loadings and corresponding glass volumes for the entire LAW inventory. 
Under a separate contract to support the WTP Project, the VSL is developing and testing glass formulations for WTP to provide data to meet the WTP contract requirements and to support system design activities [12-17]. That work is based upon small-scale batch melts ("crucible melts") using waste simulants. Selected formulations have also been tested in smallscale, continuously-fed, joule-heated melters (DM10 and DM100 systems) [10, 11, 18-27] and, ultimately, in the LAW Pilot Melter [28-39]. Such melter tests provide information on key process factors such as feed processing behavior, dynamic effects during processing, sulfate incorporation, processing rates, off-gas amounts and compositions, foaming control, etc., that cannot be reliably obtained from crucible melts. This sequential scale-up approach in the vitrification testing program ensures that maximum benefit is obtained from the more costly melter tests and that the most effective use is made of those resources.

Under the WTP support effort, VSL and EnergySolutions have developed and identified glass compositions for processing the Phase I LAW tank streams for the WTP. These compositions have been tested for processing and product quality requirements at various scales ranging from crucible melts of about $400 \mathrm{~g}$ up to the LAW Pilot Melter at processing rates in excess of $6600 \mathrm{~kg} /$ day $\left(2000 \mathrm{~kg} / \mathrm{m}^{2} /\right.$ day $)$. The testing included the nominal feed compositions and those with $\pm 15 \%$ variations in the waste simulants added to the melter feeds. The melter testing provided high confidence that the selected WTP compositions are unlikely to cause accumulation of a separate sulfate phase in the melter even at high feed processing rates. Feed processing characteristics and off-gas characteristics have been determined at various melter scales and data have been collected to support engineering and permitting requirements. Furthermore, statistically designed composition matrices were generated, and crucible melts of these glass compositions were prepared and characterized to qualify the glass composition region covering these LAW glass compositions selected for WTP waste processing [16, 17]. The selected WTP compositions have also been tested to ensure their compatibility with melter materials of construction. The glass formulation development and melter testing work for the selected WTP compositions have reached a level of maturity where the compositions can be used for waste processing at the WTP with relatively high confidence.

VSL/EnergySolutions have developed a LAW glass formulation correlation [40] that can be used to calculate glass compositions for waste processing, given the composition of an LAW stream. The correlation can be used to calculate compliant glass compositions for waste processing based on the ratios of sulfate to sodium $(\mathrm{S} / \mathrm{Na})$ and potassium to sodium $(\mathrm{K} / \mathrm{Na})$ in the LAW stream. The correlation uses a set of empirical relationships derived from the above array of test data to define waste loadings and the concentrations of glass former additives for a given LAW composition.

The glass formulation and melter testing work described in the Test Plan for this work [41] and presented in this Final Report expands this formulation approach to a wider range of LAW waste types, including those with high potassium concentration. Another objective is to assess the feasibility of formulating higher waste loading glasses without using $\mathrm{Fe}_{2} \mathrm{O}_{3}$ and $\mathrm{TiO}_{2}$ as glass former additives. Based on the results of the previous studies, the effect of $\mathrm{SnO}_{2}$ and $\mathrm{V}_{2} \mathrm{O}_{5}$ additions were further investigated to determine their utility in formulating higher waste loading LAW glasses. The results from these tests together with earlier work for ORP were 
evaluated to recommend the work scope necessary to modify and update the current WTP LAW glass formulation correlation algorithm.

The glass formulation and melter testing presented in this Final Report is aimed at identifying glass compositions that have the potential to accommodate higher waste loadings than does the present WTP baseline, for LAW compositions specified by ORP [42]. A summary of the glass formulations previously developed for the four waste compositions is specified in Table 1.1. The four WTP LAW compositions used as part of the basis for the LAW correlation, LAWE3, LAWE4H, LAWE7H, and LAWE10H, were used as the starting points for development of the new formulations. These compositions are based on the compositions of LAW tanks AP-101, AN-105, AN-102, and AZ-102, thus covering the range of sulfate to sodium and potassium to sodium ratios expected in Hanford LAW. This information will provide ORP with a basis for evaluation of the likely potential for future enhancements of the WTP over and above the present well-developed baseline. In this regard, this work is complementary to, and necessarily of a more exploratory nature than the work in support of the current WTP baseline. It should be noted, therefore, that to the extent that the present effort was successful, considerable further work would be required to bring the level of confidence in the new glass compositions to a similar level of maturity to that of the current WTP baseline.

Based on the crucible formulation logic described below, DM10 tests were performed on each of the four selected formulations. The melter tests described in this report utilized waste simulants prepared and blended with glass formers at VSL to produce the melter feed. Sufficient feed was prepared to produce over half a metric ton of glass. Reductant in the form of sugar was added to the feed at a stoichiometric ratio of 0.5 ( 1 mole sucrose per 16 moles NOx or 3 moles carbon per 4 moles NOx). The waste simulant was prepared without sulfur and a corresponding portion of the sodium such that the sulfur content could be adjusted to desired concentrations by the addition of various combinations of $\mathrm{NaOH}$ and $\mathrm{Na}_{2} \mathrm{SO}_{4}$. These tests were performed at $1150^{\circ} \mathrm{C}$ and with a nominal target glass production rate of $2,250-2,500 \mathrm{~kg} /\left(\mathrm{m}^{2} \cdot\right.$ day $)$. Each test segment was nominally 14 hours duration, which corresponds to three melter turnovers for the DM10 melter system that was employed. In each test sequence, composed of about 3 to 6 test segments, the sulfate content was progressively increased to the point at which a sulfate salt phase developed, indicating the limit of sulfate incorporation for that particular formulation. Quantitative measurements of glass production rates, melter operating conditions (temperatures, pressures, power, flows, etc.) and select gaseous emissions ( $\mathrm{NOx}, \mathrm{SO}_{2}, \mathrm{CO}$, and acid gases) were made for each test. Glass samples taken from the glass pool and the air-lift discharged glass were inspected throughout testing to determine the limit of feed $\mathrm{SO}_{3}$ concentration for operation of the melter without a separate sulfate phase.

The glass formulation development for this work followed a methodology developed by VSL/EnergySolutions during previous work. The methodology can be summarized as follows:

- Use existing glass formulation data and models to identify initial glass formulations for testing. The data used include ORP and WTP test data, data from other DOE programs, glass literature, geology, etc. 
- Characterize the first set of glasses and use the information to refine the glass formulation for the next test set (active glass formulation design approach).

- Characterize glass samples for properties that are likely to be most challenging.

- For promising glasses, complete full characterization.

- Determine sulfur loading and processing characteristics through melter tests.

The glass formulation development work relied heavily on previous work performed for ORP [2, 5-7] and relevant WTP LAW glass formulation work [12-17]. Existing propertycomposition models were used to guide glass formulation development. However, since the existing models are not expected to be reliable in the new composition regions that were explored in this work, glass science knowledge and experience and information about the effect of various additives on glass structure and properties were used as additional tools to guide glass formulation development.

\subsection{Test Objectives}

The principal objective of the work described in this Final Report is to extend the glass formulation methodology developed in the earlier work [2, 5-7, 40] by development of acceptable glass compositions for four LAW compositions specified by ORP [42] that cover the range of sulfate to sodium and potassium to sodium ratios expected in Hanford LAW. Per the ORP scope of work [42], the glass formulations were designed to exclude titanium and iron as glass former additives, while tin and vanadium as glass former additives were evaluated for beneficial effects in increasing waste loading in the glasses. This was accomplished through a combination of crucible-scale tests and tests on the DM10 melter system. The DM10 was used for several previous tests on LAW compositions $[2-7,10,11]$ to determine the maximum feed sulfur concentrations that can be processed without forming secondary sulfate phases on the surface of the melt pool. This melter is the most efficient melter platform for screening glass compositions over a wide range of sulfate concentrations and therefore was selected for the present tests. The current tests provide information on melter processing characteristics and off-gas data, including sulfur incorporation and partitioning. Other objectives of the work scope include study of the redox behavior of vanadium in LAW glasses, and measurement of the high temperature density, specific heat, and thermal conductivity of two LAW glasses, the results of which are reported separately.

The four waste types selected for testing, the starting glass compositions [43], and their respective target minimum waste loadings are given below:

- LAWE4H (based on LAW tank AN-105) with minimum waste loading of $27.18 \mathrm{wt} \%$.

- LAWE3 (based on LAW tank AP-101) with minimum waste loading of $25.41 \mathrm{wt} \%$.

- LAWE7H (based on LAW tank AN-102) with minimum waste loading of $16.22 \mathrm{wt} \%$.

- LAWE10H (based on LAW tank AZ-102) with minimum waste loading of $6.20 \mathrm{wt} \%$. 
The objectives are:

- Develop glass formulations that are compliant with processing and product quality requirements for the above four waste streams, that exceed the minimum waste loadings, without using titanium and iron as glass former additives. Evaluate the use of tin and vanadium as glass former additives to increase waste loading.

- Determine the effect of redox state on the behavior of vanadium in the glass.

- Determine the maximum feed sulfur concentrations that can be processed on the DM10 melter without the formation of secondary sulfate phases for each of the four LAW glass formulations.

- Measure the high temperature specific heat, density, and thermal conductivity of two LAW glasses.

- Develop the work scope needed to update and modify the LAW correlation algorithm [40] using the new data on high waste loading LAW glasses developed for ORP.

The effect of redox state on the behavior of vanadium in the glass as well as the measurements of the high temperature specific heat, density, and thermal conductivity of two LAW glasses have been reported separately [44].

\subsection{Quality Assurance}

This work was conducted under a quality assurance program compliant with 10 CFR 830 Subpart A, NQA-1 (2000), and DOE Order 414.1C. This program was supplemented by a Quality Assurance Project Plan for ORP work [45] that is conducted at VSL. Test and procedure requirements by which the testing activities were planned and controlled are defined in the Test Plan [41]. The program is supported by VSL standard operating procedures that were used for this work [46]. The requirements of DOE/RW-0333P are not applicable to this work. 


\section{SECTION 2.0 WASTE SIMULANTS, GLASS FORMULATIONS AND FEED ANALYSIS}

Glass formulation development and melter testing were conducted to identify compliant high waste loading glass formulations for Hanford LAW streams. The glass formulations covered a large portion of the expected range of $\mathrm{Na}_{2} \mathrm{O}$ and $\mathrm{SO}_{3}$ concentrations expected for LAW glasses. Based on the target $\mathrm{Na}_{2} \mathrm{O}$ and $\mathrm{SO}_{3}$ concentrations in the glasses, the glass formulation development was divided to focus on four LAW streams. The four waste types, their respective target sodium and sulfur loadings, and the starting glass compositions as given in the Test Plan [41], are:

- Region A: starting from LAW correlation glass composition LAWE4H [43] (based on LAW tank AN-105) with a minimum waste loading of $27.18 \mathrm{wt} \%$.

- Region D: starting from LAW correlation glass composition LAWE7H [43] (based on LAW tank AN-102) with minimum waste loading of $16.22 \mathrm{wt} \%$.

- Region F: starting from LAW correlation glass composition LAWE10H [43] (based on LAW tank AZ-102) with minimum waste loading of $6.20 \mathrm{wt} \%$.

- Region G: starting from LAW correlation glass composition LAWE3 [43] (based on LAW tank AP-101) with a minimum waste loading of $25.41 \mathrm{wt} \%$.

The waste simulant and glass formulations developed for each of the above composition regions are described in Sections 2.1 through 2.4. Other LAW composition regions with different sodium and sulfur concentrations have been studied previously [5-7].

The intent of the testing was, while targeting the above values, to determine the highest achievable $\mathrm{Na}_{2} \mathrm{O}$ and $\mathrm{SO}_{3}$ loadings for each of the waste streams. Thus, as the formulation work progressed and data from testing became available, the target $\mathrm{Na}_{2} \mathrm{O}$ and $\mathrm{SO}_{3}$ concentrations in the glass formulations were revised.

During the planning stages of this work, a total of 40 crucible melts were budgeted to develop glass formulations for all four regions. In order to satisfy budget constraints, more effort was focused on the measurement of glass properties that were judged to be most challenging for each set of glasses. Properties that were judged likely to be compliant with contract and processing requirements were either not measured, or measured only on select samples. The most economical and efficient way to make the best use of a limited number of crucible melts is to prepare and characterize them in very small sets using data from the previous sets to guide the design of the next set. In addition, it is most economical to limit initial characterization of the glasses to the properties that are likely to be the most challenging to meet; further 
characterization need then be done only on those samples that pass the initial tests. However, since VHT was the most challenging criterion to meet and the VHT test duration is 24 days, time constraints did not always allow the above approach. In many cases, schedule constraints demanded that a larger number of crucible melts be made together and measurements of different glass properties be done in parallel in order to complete the work in the scheduled amount of time.

\subsection{Region A (ORPLA) Waste Simulant and Glass Formulation}

Glass formulation development and testing for Region A (ORPLA) were based on the composition of LAW material from Hanford tank AN-105. Details of the waste simulant and glass formulation development and testing are given below.

\subsubsection{Region A (ORPLA) Waste Simulant for Tank AN-105}

A LAW Envelope A waste simulant based on the composition data for tank AN-105, as given in a WTP Test Specification [47], was used as the basis for Region A glass formulations. The base waste composition incorporates TFCOUP [48] data, actual waste analysis data, and WTP flow sheet information. The sodium concentration in the simulant includes a $2.5 \%$ increase to account for sodium additions in pretreatment $[13,49]$. The nominal concentration, expressed in terms of the sodium molarity, was determined on the basis of melter feed rheology tests on similar formulations $[50,51]$. The results of those tests led to the selection of 8.0 molar sodium as the nominal simulant concentration for the LAW AN-105 waste. This is the same concentration that was used in previous WTP melter tests for LAW AN-105 waste $[18,25,52]$.

The nominal simulant formulation is given in Table 2.1. The LAW AN-105 simulant is a solution of predominantly sodium, aluminum, nitrate, nitrite and hydroxide. Since the simulant was similar to those tested previously at the VSL, it was not necessary to prepare and perform screening tests on new laboratory samples. A single simulant batch of about 32 gallons was prepared at VSL for the DM10 melter tests. Glass forming chemicals and sugar as a reductant were added directly to the 55-gallon drum, while the requisite combinations of sodium hydroxide and sodium sulfate were added to adjust the sodium and sulfur contents in smaller feed sub-batches for each test segment.

\subsubsection{Region A (ORPLA) Glass Formulation}

Glass formulation development for Region A (ORPLA) was based on the composition of the LAW AN-105 waste stream. The objective was to develop a glass formulation that can accommodate a minimum waste loading of $27.18 \mathrm{wt} \%$. Since the $\mathrm{Na}_{2} \mathrm{O}$ concentration in the waste is $77.25 \mathrm{wt} \%$ with $0.59 \mathrm{wt} \% \mathrm{SO}_{3}$, high sulfate loading in the glass was not a primary objective in glass formulation development for this region. To meet the minimum waste loading requirement, the target $\mathrm{Na}_{2} \mathrm{O}$ and $\mathrm{SO}_{3}$ loadings in the ORPLA glasses were $21 \mathrm{wt} \%$ and 0.16 
$\mathrm{wt} \%$, respectively. Based on testing of a previous set of seventeen crucible melts with $\mathrm{Na}_{2} \mathrm{O}$ concentrations in the range of 23.5 to $25 \mathrm{wt} \%$ [7], the minimum $\mathrm{Na}_{2} \mathrm{O}$ concentration in the new formulations selected for testing was set at $24 \mathrm{wt} \%$. Eight new crucible melts were prepared and characterized in an effort to identify a new glass formulation that meets all of the processing and product quality requirements [53, 54]. The target and analyzed compositions of the crucible melts are given in Table 2.2. The glass sodium content was initially set at a concentration of 24 $\mathrm{wt} \% \mathrm{Na}_{2} \mathrm{O}$, as was effectively tested before in glass ORPLA15 [7]. In contrast to ORPLA15, the new glass formulations did not have iron oxide as a glass former additive, which was compensated by small increases in the amounts of aluminum, boron, and zinc additives. Five of the eight new formulations were formulated with $24 \mathrm{wt} \% \mathrm{Na}_{2} \mathrm{O}$, two with $25 \mathrm{wt} \% \mathrm{Na}_{2} \mathrm{O}$, and one with 26 wt $\% \mathrm{Na}_{2} \mathrm{O}$.

Tin was first considered as a potential glass former additive for Hanford LAW in work performed at VSL in 1999, while studying the effect of various group IV metals in the Periodic Table on LAW glasses [13]. Tin was observed to improve the LAW glass VHT performance but also to decrease sulfate solubility [55-57]. Since increasing sulfate solubility was the main focus of the glass development efforts at that time, less effort was directed at compositions containing tin. However, since recent projections show higher sodium additions in pretreatment at Hanford, there is increased interest in increasing sodium loadings in LAW glasses, which makes glass compositions with tin potentially more valuable. Titanium, zirconium, and tin have certain similarities in their electronic structure ( $\mathrm{d} 2 \mathrm{~s} 2$ for titanium and zirconium and $\mathrm{d} 10 \mathrm{~s} 2 \mathrm{p} 2$ for tin) which leads to some similarity in their properties. Zirconia is added primarily to improve the chemical durability of the glass, but it also tends to cause zircon crystallization if added in excess of about $5 \mathrm{wt} \%$. Similarly, titanium is a known effective nucleating agent [58]. Substituting tin oxide for titania presents the advantage of potentially improving leach resistance without increasing the tendency for crystallization. In the new formulations, tin and zirconium oxide concentrations together were kept above $8.75 \mathrm{wt} \%$ to maintain leach resistance, but their molar ratios were varied from $1 / 3: 2 / 3$ (ORPLA18) to $1 / 2: 1 / 2$ (ORPLA19). A similar strategy was used to develop two more $24 \mathrm{wt} \%-\mathrm{Na}_{2} \mathrm{O}$ formulations, but without magnesium oxide addition (ORPLA22 and ORPLA23). Since the most common source of magnesium, olivine, brings about $8 \mathrm{wt} \%$ iron oxide as fayalite $\left(\mathrm{Fe}_{2} \mathrm{SiO}_{4}\right)$ mixed with forsterite $\left(\mathrm{Mg}_{2} \mathrm{SiO}_{4}\right)$, iron oxide is present in glass formulations containing magnesium, even though iron oxide is not specifically added as a glass former. The removal of magnesium allows testing of glass compositions containing no iron oxide. In one of the $24 \mathrm{wt} \% \mathrm{Na}_{2} \mathrm{O}$ formulations (ORPLA20), the alumina content was decreased by $3 \mathrm{wt} \%$ with a corresponding increase in the silica content, which is predicted to decrease Vapor Hydration Test (VHT) alteration rate and increase sulfate solubility. This glass did have the highest sulfate solubility for Region A glasses and also showed acceptable performance on VHT.

The successful strategy with lower alumina in ORPLA20 was further tested at $25 \mathrm{wt} \%$ $\mathrm{Na}_{2} \mathrm{O}$ in ORPLA21. Glasses devoid of magnesium and iron were also tested at 25 and $26 \mathrm{wt} \%$ $\mathrm{Na}_{2} \mathrm{O}$. For these very high $\mathrm{Na}_{2} \mathrm{O}$ glasses, the properties of most concern are VHT alteration rate and K-3 refractory corrosion. In order to reduce K-3 refractory corrosion, $\mathrm{Cr}_{2} \mathrm{O}_{3}$ was added at a concentration of about $0.5 \mathrm{wt} \%$ in addition to maintaining $\mathrm{Al}_{2} \mathrm{O}_{3}, \mathrm{SiO}_{2}, \mathrm{SnO}_{2}$, and $\mathrm{ZrO}_{2}$ concentrations at high levels [7]. VHT alteration rates of these glasses were high, but remained 
The Catholic University of America Vitreous State Laboratory
Glass Formulation Development and DM10 Melter Testing with ORP LAW Glasses

Final Report, VSL-09R1510-2, Rev. 0

within the contractual limit. The four glasses with the highest sulfate solubilities were tested for their K-3 corrosion characteristics, and only ORPLA20 showed acceptable behavior.

Target and analyzed compositions of the ORPLA glasses are given in Table 2.2. Glass compositions were determined by X-ray Fluorescence Spectroscopy (XRF) on powdered glass samples, except for $\mathrm{B}_{2} \mathrm{O}_{3}$, which was measured by Direct Current Plasma - Atomic Emission Spectroscopy (DCP-AES) after acid dissolution. As is evident from the table, the target and analyzed compositions show good agreement. Testing of all formulations started with glass preparation and optical microscopic evaluation of the as-melted sample. Glass samples were heat treated for 20 hours at $950^{\circ} \mathrm{C}$ and then evaluated for secondary phases. Observations of the as-melted and heat treated glasses are given in Table 2.3. All of the as-melted glasses appeared clear with some containing small amounts $(<0.1 \mathrm{vol} \%)$ of chromium oxide crystals. Since these crystals are not detected after heat treatment, they can be attributed to incomplete dissolution of the chromium oxide additive. Some of the heat treated glasses showed spinel crystals. Since the glasses have high $\mathrm{ZrO}_{2}$ contents, Na-Zr-silicate crystals were present in most of them except for ORPLA20 with a high $\mathrm{ZrO}_{2}$ content of $6.0 \mathrm{wt} \%$ and ORPLA19 with the lowest $\mathrm{ZrO}_{2}$ content of $3.93 \mathrm{wt} \%$. Sn-containing crystals also were detected in these glasses, with the exception of ORPLA20, with a comparatively lower $\mathrm{SnO}_{2}$ concentration, combined with lower $\mathrm{Al}_{2} \mathrm{O}_{3}$ and higher $\mathrm{SiO}_{2}$ concentrations.

The sulfate solubilities of the ORPLA glass compositions were assessed by batch saturation tests. This is a crucible-scale screening test that is used to obtain an indication of the extent of sulfur incorporation that will be obtained under actual melter operating conditions, which is, of course, the measure that is of practical importance. The results of these screening tests are then used to guide the range of sulfur concentrations over which the melter tests are performed. The batch saturation tests were performed by remelting finely ground samples of the glasses with an excess of sulfate amounting to $4 \mathrm{wt} \% \mathrm{SO}_{3}$ if all of it were retained in the glass. The remelted glass samples are identified with an $\mathrm{S} 4$ at the end of the sample name. Results of sulfate batch saturation tests are given in Table 2.4 and Figure 2.1. The results identified as "after acid wash" are analyses of glass samples remelted with $4 \mathrm{wt} \% \mathrm{SO}_{3}$ after grinding and washing to remove any interstitial sulfate phases, to ensure that only the $\mathrm{SO}_{3}$ that is dissolved in the glass is measured. The sulfate retentions in the glasses ("after acid wash") varied from about $0.30 \mathrm{wt} \%$ $\mathrm{SO}_{3}$ for ORPLA18 to $0.41 \mathrm{wt} \% \mathrm{SO}_{3}$ for ORPLA25.

VHT and PCT results are summarized in Table 2.5 and illustrated in Figures 2.2 and 2.3. The results show that although none of the new formulation exceeded the VHT alteration rate requirement of $50 \mathrm{~g} / \mathrm{m}^{2} /$ day, three of these ORPLA glasses showed high alteration depths. This was not unexpected because the VHT requirement becomes more challenging as the alkali content of the glasses is increased, which is why all of the glasses were formulated with high concentrations of $\mathrm{SnO}_{2}$ and $\mathrm{ZrO}_{2}$ in order to counteract the effects of high alkali. As expected, VHT alteration rates increase with increases in $\mathrm{Na}_{2} \mathrm{O}$ content. Comparison of the VHT results of ORPLA20 and ORPLA18 shows that increases in $\mathrm{SiO}_{2}$ concentration with a corresponding decrease in the $\mathrm{Al}_{2} \mathrm{O}_{3}$ concentration, leads to a decrease in the VHT alteration rate. Removal of $\mathrm{MgO}$ and $\mathrm{Fe}_{2} \mathrm{O}_{3}$ from the glass composition combined with higher $\mathrm{SnO}_{2}$ concentration also seems to improve the VHT performance of these high alkali glasses. PCT releases for the glasses 
given in Table 2.5 and Figure 2.3 show that all of the glasses met the ILAW product quality requirement of normalized mass loss of less than $2 \mathrm{~g} / \mathrm{m}^{2}$ for $\mathrm{B}$, Na, and Si. For the eight ORPLA glasses that were studied, the PCT releases do not show any clearly discernable effect of glass composition.

The viscosities and electrical conductivities of three of the glasses at select temperatures are given in Table 2.6. Viscosities and electrical conductivities of the remaining glasses were not measured because they failed the K-3 corrosion criterion. All of the measured viscosities and electrical conductivity values are in the acceptable range for melt processing [53] at WTP. Note that the glasses were designed to have viscosities towards the high limit for acceptability in order to reduce refractory corrosion.

K-3 refractory corrosion is a significant concern, due to the high alkali content of the ORPLA glass formulations. The four glasses with the highest alkali contents and sulfate solubilities were tested for their K-3 corrosion characteristics. K-3 refractory corrosion test results for these glasses are given in Table 2.7 and Figure 2.4, where they are compared to the results for some of the previously tested ORP LAW glasses [7]. All but one of the glasses, ORPLA20, had unacceptable K-3 corrosion characteristics, which could impact melter life. Acceptability of the corrosion characteristics of a glass composition is somewhat subjective because a glass composition that shows slightly higher K-3 corrosion, but allows higher waste loading, may be a more economic choice than one with lower K-3 corrosion and lower waste loading. However, for WTP LAW glass formulation development, a neck corrosion of 0.035 inches on the 6-day K-3 coupon corrosion test at $1208^{\circ} \mathrm{C}$ has been used as an acceptance limit. For the current LAW glass formulation development work for ORP, since higher waste loading compositions are being explored, a slightly higher neck corrosion value of 0.040 inches has been used as a guide for acceptable corrosion characteristics.

With the exception of K-3 corrosion, all eight of the new ORPLA glass formulations met the processing and product quality requirements for melt processing at WTP. However, only one of the glasses, ORPLA20, met the K-3 corrosion criterion and was, therefore, selected for DM10 melter tests. The measured properties of the glass ORPLA20 are compared to the ILAW performance requirements $[53,54]$ in Table 2.8 . Density and glass transition temperature $\left(\mathrm{T}_{\mathrm{g}}\right)$ measurements and canister centerline cooling (CCC) heat treatments were not conducted on ORPLA20 samples because the glass is expected to be acceptable with respect to these properties. The only requirement for $\mathrm{T}_{\mathrm{g}}$ is that it be measured and reported. Even though density was not measured for the ORPLA20 crucible glass, the density was measured for a glass sample from the DM10 melter test and the value is within the acceptable limit. In addition, none of the measured densities of LAW glasses prepared for WTP or ORP exceeded or even approached the limit of $3.7 \mathrm{~g} / \mathrm{cc}$. Since the sample heat treated at $950^{\circ} \mathrm{C}$ for 20 hours showed only $0.3 \mathrm{vol} \%$ of crystals, CCC treatment is not expected to cause extensive crystallization. Although cooling of the glass discharged from the DM10 melter occurs faster than in a WTP LAW canister, examination of cooled ORPLA20 glass samples from the DM10 melter corroborated this expectation in that very few crystals were present in the discharge glass samples. 
The composition of the ORPLA20 glass used in melter tests is given in Table 2.9 along with the oxide contributions from the LAW AN-105 waste simulant and from the glass former additives. The simulant was prepared with no $\mathrm{SO}_{3}$ and the sulfur concentration was increased in steps during the melter tests by adding the appropriate amounts of $\mathrm{Na}_{2} \mathrm{SO}_{4}$ and $\mathrm{NaOH}$ to the feed. The melter feed was prepared at a $\mathrm{Na}_{2} \mathrm{O}$ concentration of $23.25 \mathrm{wt} \%$ (for zero sulfate) in order to accommodate $\mathrm{Na}_{2} \mathrm{SO}_{4}$ and $\mathrm{NaOH}$ additions, without increasing the $\mathrm{Na}_{2} \mathrm{O}$ concentration above $24.0 \mathrm{wt} \%$ while accommodating up to $0.96 \mathrm{wt} \% \mathrm{SO}_{3}$. The types and amounts of glass former additives used to prepare the melter feed along with the target feed properties are given in Table 2.10a. The glass former additives are the same as those planned for use at the WTP, with the exception of chromium and tin, which would be new additives. The amounts of $\mathrm{Na}_{2} \mathrm{SO}_{4}$ and $\mathrm{NaOH}$ added to the feed to obtain $24 \mathrm{wt} \% \mathrm{Na}_{2} \mathrm{O}$ and 0.20 to $0.90 \mathrm{wt} \% \mathrm{SO}_{3}$ are given in Table 2.10b.

\subsection{Region D (ORPLD) Waste Simulant and Glass Formulation}

Glass formulation development and testing for Region D (ORPLD) were based on the composition of LAW material from Hanford tank AN-102. Details of the waste simulant and glass formulation development and testing are given below.

\subsubsection{Region D (ORPLD) Waste Simulant for Tank AN-102}

A LAW Envelope C waste simulant based on the composition data for tank AN-102, as given in a WTP Test Specification [47], was used as the basis for ORPLD glass formulations. The base waste composition incorporates TFCOUP [48] data, actual waste analysis data, and WTP flow sheet information. The sodium concentration in the simulant includes a $17.65 \%$ increase to account for sodium additions in pretreatment $[13,49]$. The nominal concentration, expressed in terms of the sodium molarity, was estimated on the basis of melter feed rheology tests on similar formulations $[50,51]$. The concentration of the simulant used in melter tests was 8.0 molar sodium. This is higher than that used in previous WTP LAW melter tests [24, 27] because of the higher waste loading in the ORPLD glasses, but similar to previous ORP melter tests [7]. It is considered that any further increase in waste loading would still not justify increasing the simulant concentration beyond 8 Molar $\mathrm{Na}$ due to concerns related to sodium nitrate crystallization [51].

The nominal simulant formulation is given in Table 2.11. The LAW AN-102 simulant is a solution of predominantly sodium, nitrate, nitrite, and sulfate. Preparation of the waste simulant and melter feed were done in a manner similar to that for ORPLA simulant, which is described in Section 2.1.1. 


\subsubsection{Region D (ORPLD) Glass Formulation}

Glass formulation development for Region D (ORPLD) was based on the composition of the LAW AN-102 waste stream. The objective was to develop a glass formulation that can accommodate a minimum waste loading of $16.22 \mathrm{wt} \%$, as achieved in the LAW correlation glass LAWE7H [52]. Earlier studies with this waste composition for ORP resulted in the development of a high waste loading glass $\left(24.7 \mathrm{wt} \%\right.$ ) with a target $\mathrm{SO}_{3}$ loading of about $0.6 \mathrm{wt} \%$. Building on the previous results, six new crucible melts were prepared in an effort to identify a glass formulation that meets all processing and product quality requirements, but with higher waste loading. This is a challenging region for glass formulation because the alkali content is still relatively high, but the target $\mathrm{SO}_{3}$ loading is higher in Region $\mathrm{D}$ glasses than for Region $\mathrm{A}$, Region B, and Region $\mathrm{C}$ glasses [7]. The target and analyzed compositions of the new glasses are given in Table 2.12. To increase sulfate solubility, 1 to $3 \mathrm{wt} \%$ of $\mathrm{V}_{2} \mathrm{O}_{5}$ was added to all six of the new ORPLD glass formulations, and iron was removed as a glass former additive. Note, however, that about $0.3 \mathrm{wt} \%$ of $\mathrm{Fe}_{2} \mathrm{O}_{3}$ is still present in the final glass compositions because of contribution from olivine used as a magnesium source. The waste loading was increased in steps, from $25 \mathrm{wt} \%$, to 26 and $27 \mathrm{wt} \%$, leading to glasses containing 21,22 and $23 \mathrm{wt} \% \mathrm{Na}_{2} \mathrm{O}$, respectively. The zirconia concentration was increased from $3 \mathrm{wt} \%$ in ORPLD 4 to $4 \mathrm{wt} \%$ in the other five glasses, and tin oxide was added to ORPLD7, ORPLD8 and ORPLD9 to improve the performance on PCT, VHT, and K-3 refractory corrosion tests. In order to reduce K-3 refractory corrosion, $\mathrm{Cr}_{2} \mathrm{O}_{3}$ was added at a concentration of about $0.5 \mathrm{wt} \%$ to all of the glasses.

Target and analyzed compositions of the ORPLD glasses are given in Table 2.12. Testing and analysis of the glasses followed the same methods used for ORPLA glasses, which are described in Section 2.1.2. As is evident from the table, the target and analyzed compositions show good agreement. Glass samples were heat treated for 20 hours at $950^{\circ} \mathrm{C}$ and evaluated for secondary phases. Observations of the as-melted, and heat treated glasses are given in Table 2.13. All of the as-melted glasses appeared clear with small amounts $(0.1 \mathrm{vol} \%$ or less $)$ of crystals. The heat treated glasses also showed little crystallization ( $0.3 \mathrm{vol} \%$ or less on average).

The sulfate solubilities of the ORPLD glass compositions were assessed by batch saturation tests. The batch saturation tests are described in Section 2.1.2 and the results of the tests are given in Figure 2.1 and Table 2.14. The sulfate solubilities of the ORPLD glasses varied little in the series, from 0.86 to $0.95 \mathrm{wt} \%$ by batch saturation tests. VHT and PCT results are summarized in Table 2.15 and illustrated in Figures 2.2 and 2.3. All six of the glasses met the PCT release and VHT alteration rate limits. ORPLD9 with the highest $\mathrm{Na}_{2} \mathrm{O}$ content of 23 wt $\%$ and $\mathrm{V}_{2} \mathrm{O}_{5}$ content of $\sim 3 \mathrm{wt} \%$ showed the highest VHT alteration rate of $42 \mathrm{~g} / \mathrm{m}^{2} /$ day which is close to the limit of $50 \mathrm{~g} / \mathrm{m}^{2} /$ day. The viscosities and electrical conductivities of the six glasses at select temperatures are given in Table 2.16. The measured values are all within the acceptable processing ranges, but the viscosities are towards the lower end of the range which is a concern with respect to K-3 refractory corrosion. K-3 refractory corrosion test results for the four glasses with the highest waste loadings are given in Table 2.17 and Figure 2.4. Only ORPLD6 met the limit of $\leq 0.040$ inches of neck loss in the K-3 corrosion test. 
Of the six ORPLD glass formulations tested, only one, ORPLD6, met all processing and product quality requirements and was, therefore, selected for melter testing. Note that similar to Region A glasses, K-3 refractory corrosion was the most constraining glass property. The measured properties of the glass ORPLD6 are compared to the ILAW performance requirements $[53,54]$ in Table 2.18. Density and glass transition temperature measurements, and canister centerline cooling (CCC) heat treatments were not conducted on ORPLD6 crucible glass, but density was measured on the glass produced in the DM10 melter. Examination of cooled ORPLD6 glass samples from the melter showed little crystallization, indicating that the glass is unlikely to show substantial crystallization on CCC heat treatment.

The composition of the ORPLD6 glass used in melter tests is given in Table 2.19 along with the oxide contributions from the LAW AN-102 waste simulant and from the glass former additives. The simulant was procured with no $\mathrm{SO}_{3}$ and the sulfur concentration was increased in steps during the melter tests by adding the appropriate amounts of $\mathrm{Na}_{2} \mathrm{SO}_{4}$ and $\mathrm{NaOH}$ to the feed. The melter feed was procured at a $\mathrm{Na}_{2} \mathrm{O}$ concentration of $20.44 \mathrm{wt} \%$ in order to accommodate $\mathrm{Na}_{2} \mathrm{SO}_{4}$ (for $\mathrm{SO}_{3}$ up to $2 \mathrm{wt} \%$ ) and $\mathrm{NaOH}$ additions, without increasing the $\mathrm{Na}_{2} \mathrm{O}$ concentration above $22.0 \mathrm{wt} \%$. The types and amounts of glass former additives used to prepare the melter feed along with the target feed properties are given in Table 2.20a. The glass former additives are the same as those planned for use at the WTP, with the exception of chromium and vanadium, which would be new additives. The amounts of $\mathrm{Na}_{2} \mathrm{SO}_{4}$ and $\mathrm{NaOH}$ added to the feed to obtain $22.0 \mathrm{wt} \% \mathrm{Na}_{2} \mathrm{O}$ and 0.0 to $1.3 \mathrm{wt} \% \mathrm{SO}_{3}$ are given in Table $2.20 \mathrm{~b}$.

\subsection{Region F (ORPLF) Waste Simulant and Glass Formulation}

Glass formulation development and testing for Region F (ORPLF) were based on the composition of LAW material from Hanford tank AZ-102. Details of the waste simulant and glass formulation development and testing are given below.

\subsubsection{Region F (ORPLF) Waste Simulant for Tank AZ-102}

A LAW Envelope B waste simulant based on the composition data for tank AZ-102, as given in a WTP Test Specification [47], was used as the basis for Region F glass formulations. The base waste composition incorporates TFCOUP [48] data, actual waste analysis data, and WTP flow sheet information. The sodium concentration in the simulant includes a 5.33\% increase to account for sodium additions in pretreatment [13, 49]. The nominal concentration, expressed in terms of the sodium molarity, was estimated on the basis of melter feed rheology tests on similar formulations $[50,51]$. The concentration of the simulant used in melter tests was 5.5 Molar sodium. This is higher than that used in previous melter tests $[22,37]$ because of the higher waste loading in the ORPLF glasses. Laboratory testing for this feed simulant was performed at 5 Molar $\mathrm{Na}$, based on extrapolation of data from previously measured feed rheologies [7, 51]. Results from the feed rheology tests given in Figure 2.5, indicated that a slight increase in the concentration of the feed can be accommodated. Accordingly, the feed for the DM10 melter test was prepared at a concentration of 5.5 Molar Na. 
The nominal simulant formulation is given in Table 2.21. The LAW AZ-102 simulant is a solution of predominantly sodium, nitrate, and sulfate. Preparation of the waste simulant and melter feed were done in a manner similar to that for ORPLA simulant, which is described in Section 2.1.1.

\subsubsection{Region F (ORPLF) Glass Formulation}

Glass formulation development for Region F (ORPLF) was based on the composition of the LAW AZ-102 waste stream. Fourteen crucible melts were prepared in an effort to identify a glass formulation that meets all processing and product quality requirements. The target and analyzed compositions of the glasses are given in Table 2.22. Unlike ORPLA and ORPLD glasses, ORPLF glasses were designed at lower sodium concentrations since sulfate content is the highest for this waste. Addition of lithium and higher amounts of calcium were also used to increase sulfate solubility. Since these glass compositions contained fairly large concentrations of both $\mathrm{Na}_{2} \mathrm{O}(10-13 \mathrm{wt} \%)$ and $\mathrm{Li}_{2} \mathrm{O}(3.45-5 \mathrm{wt} \%)$ to increase waste loading, $\mathrm{K}-3$ refractory corrosion was a concern. Accordingly, in order to reduce $\mathrm{K}-3$ refractory corrosion, $\mathrm{Al}_{2} \mathrm{O}_{3}, \mathrm{SiO}_{2}$, and $\mathrm{ZrO}_{2}$ concentrations were maintained at high levels in all the glasses, and $\mathrm{Cr}_{2} \mathrm{O}_{3}$ was added at a concentration of about $0.5 \mathrm{wt} \%$ to all of the glasses. To improve $\mathrm{VHT}$ performance, $\mathrm{ZrO}_{2}$ was maintained at high concentrations $(>3.8 \mathrm{wt} \%)$ and $\mathrm{SnO}_{2}$ was also tested in six of the glasses [55-57]. Since the target $\mathrm{SO}_{3}$ loadings were higher in ORPLF glasses as compared to the ORPLA and ORPLD glasses, $\mathrm{V}_{2} \mathrm{O}_{5}$ was also added to all of the ORPLF glass formulations.

The first series of ORPLRF glasses were prepared with waste loadings in the range of 12 to $16 \mathrm{wt} \%$. The corresponding $\mathrm{Na}_{2} \mathrm{O}$ concentrations varied from 10 to $13 \mathrm{wt} \%$ with $\mathrm{Na}_{2} \mathrm{O}$ at $10 \mathrm{wt} \%$ in ORPLF1, $11 \mathrm{wt} \%$ in ORPLF2, $12 \mathrm{wt} \%$ in ORPLF3 and ORPLF4, and $13 \mathrm{wt} \%$ in ORPLF5 and ORPLF6. Note that with this increasing waste loading, target sulfate concentrations also increased from 1.6 to $2.1 \mathrm{wt} \% \mathrm{SO}_{3}$. In this series, the effect of increasing $\mathrm{V}_{2} \mathrm{O}_{5}$ concentration by about $1.25 \mathrm{wt} \%$ and decreasing the $\mathrm{Al}_{2} \mathrm{O}_{3}$ concentration by the same amount on sulfate solubility was also tested in two sets of glasses (ORPLF3 and ORPLF4, and ORPLF5 and ORPLF6). Results from the first series of ORPLF glasses showed that VHT alteration rate requirement can be met fairly easily, thus reducing the need for $\mathrm{SnO}_{2}$ addition, while $\mathrm{Li}_{2} \mathrm{O}$ and $\mathrm{V}_{2} \mathrm{O}_{5}$ concentrations needed to be increased to improve sulfate solubility.

In the following series of ORPLF melts, $\mathrm{Li}_{2} \mathrm{O}$ concentration was increased to $4.35 \mathrm{wt} \%$ in ORPLF7 and $5 \mathrm{wt} \%$ in ORPLF8, but maintained at $3.5 \mathrm{wt} \%$ in ORPLF9 to ORPLF13. Higher $\mathrm{Li}_{2} \mathrm{O}$ concentrations clearly increased the sulfate loading, although this also increased the corrosion of K-3 refractory by the glass melt. $\mathrm{V}_{2} \mathrm{O}_{5}$ concentrations were tested at $2.5 \mathrm{wt} \%$ or $2.75 \mathrm{wt} \%$. To completely eliminate iron from the glass composition, magnesium was also removed in ORPLF13 and ORPLF4 and the $\mathrm{CaO}$ concentration was increased. Phosphorous was also considered as a new additive for improved sulfate loading in ORPLF9, where $2 \mathrm{wt} \% \mathrm{P}_{2} \mathrm{O}_{5}$ was added with decreases in $\mathrm{Al}_{2} \mathrm{O}_{3}$ (less $1 \mathrm{wt} \%$ ), $\mathrm{B}_{2} \mathrm{O}_{3}$ (less $0.65 \mathrm{wt} \%$ ), and $\mathrm{SiO}_{2}($ less $0.32 \mathrm{wt} \%$ ). 
Target and analyzed compositions of the ORPLF glasses are given in Table 2.22. Testing and analysis of the glasses followed the same methods used for ORPLA glasses, which are described in Section 2.1.2. As is evident from the table, the target and analyzed compositions show good agreement. Glass samples were heat treated for 20 hours at $950^{\circ} \mathrm{C}$ and then evaluated for secondary phases. Observations of the as-melted and heat treated glasses are given in Table 2.23. All of the as-melted glasses appeared clear with very small amounts $(<0.2 \mathrm{vol} \%)$ of crystals. The heat treated glasses also showed little crystallization $(\leq 0.3 \mathrm{vol} \%)$.

The sulfate solubilities of the ORPLF glass compositions were assessed by batch saturation tests as described in Section 2.1.2. The results of the tests are given in Figure 2.1 and Table 2.24. The measured sulfate concentrations in the ORPLF glasses varied from 1.19 to $1.45 \mathrm{wt} \%$ after acid washing of the saturated glass and 1.39 to $1.86 \mathrm{wt} \%$ before the acid wash, with the highest sulfate concentrations in ORPLF7 (4.35 wt $\left.\% \mathrm{Li}_{2} \mathrm{O}\right)$ and ORPLF8 $\left(5 \mathrm{wt} \% \mathrm{Li}_{2} \mathrm{O}\right)$.

VHT and PCT results are summarized in Table 2.25 and illustrated in Figures 2.2 and 2.3. All of the glasses met the PCT release and VHT alteration rate limits. VHT alteration rate for glass ORPLF9 with $2 \mathrm{wt} \% \mathrm{P}_{2} \mathrm{O}_{5}$ addition was the highest among all fourteen glasses. The viscosities and electrical conductivities of eleven of the ORPLF glasses at select temperatures are given in Table 2.26. All of the viscosity and electrical conductivity values are in the acceptable range for processing, but, because of the $\mathrm{Li}_{2} \mathrm{O}$ addition, the viscosity values are towards the lower part of the acceptable range. Seven of the ORPLF glasses with some of the highest sulfate solubilities were tested for their K-3 corrosion characteristics. K-3 refractory corrosion test results for the glasses are given in Table 2.27 and Figure 2.4. The concern in this case is no longer the corrosion of the K-3 material at the neck (melt-air interface) and, in fact, all of the glasses passed the requirement of less than 0.04 inches neck loss. However, the presence of lithium in the glass melt combined with low viscosity leads to infiltration of the K-3 material at the grain boundaries [59] with fairly large penetration depth and formation of wide cracks within the test coupon. Large cracks were observed in K-3 coupons exposed to glass ORPLF8 and, to a much lesser extent, in K-3 coupons exposed to ORPLF4, ORPLF7, and ORPLF10. Two of these glasses, ORPLF7 and ORPLF10, were tested twice to confirm their K-3 corrosion characteristics before selection of a glass composition for DM10 melter tests. In one of the tests, the low viscosity led to molten glass splashing on the alumina refractory cover that holds the coupon and serves as the lid of the platinum crucible in which the test is conducted (with bubbling), which contaminated the melt with alumina and compromised the test.

Among the fourteen ORPLF glass formulations tested, the two highest sulfate solubilities were observed for glasses ORPLF7 and ORPLF8. However, these glasses also showed some cracking of the K-3 refractory coupons. After duplicate K-3 corrosion tests, ORPLF7 was selected for DM10 melter tests because it met all processing and product quality requirements and showed the highest sulfate solubility. The measured properties of glass ORPLF7 are compared to the ILAW performance requirements $[53,54]$ in Table 2.28. Density and glass transition temperature measurements and canister centerline cooling (CCC) heat treatments were not conducted on ORPLF7 crucible glass but the density was measured on a glass sample from DM10 melter testing. Examination of cooled ORPLF7 glass samples from the melter tests 
showed little crystallization, indicating that the glass is unlikely to show substantial crystallization on CCC heat treatment.

The composition of the ORPLF7 glass used in melter tests is given in Table 2.29 along with the oxide contributions from the LAW AZ-102 waste simulant and from the glass former additives. The simulant was procured with no $\mathrm{SO}_{3}$ and the sulfur concentration was increased in steps during the melter tests by adding the appropriate amounts of $\mathrm{Na}_{2} \mathrm{SO}_{4}$ and $\mathrm{NaOH}$ to the feed. The melter feed was prepared at a $\mathrm{Na}_{2} \mathrm{O}$ concentration of $10.45 \mathrm{wt} \%$ in order to accommodate $\mathrm{Na}_{2} \mathrm{SO}_{4}$ and $\mathrm{NaOH}$ additions without increasing the $\mathrm{Na}_{2} \mathrm{O}$ concentration above $12.00 \mathrm{wt} \%$. The types and amounts of glass former additives used to prepare the melter feed along with the target feed properties are given in Table 2.30a. The glass former additives are the same as those planned for use at the WTP, with the exception of chromium, and vanadium, which would be new additives. The amounts of $\mathrm{Na}_{2} \mathrm{SO}_{4}$ and $\mathrm{NaOH}$ added to the feed to obtain $12.00 \mathrm{wt} \% \mathrm{Na}_{2} \mathrm{O}$ and 0.0 to $1.7 \mathrm{wt} \% \mathrm{SO}_{3}$ are given in Table $2.30 \mathrm{~b}$.

\subsection{Region G (ORPLG) Waste Simulant and Glass Formulation}

Glass formulation development and testing for Region G (ORPLG) were based on the composition of LAW material from Hanford tank AP-101. Details of the waste simulant and glass formulation development and testing are given below.

\subsubsection{Region G (ORPLG) Waste Simulant for Tank AP-101}

A LAW Envelope A waste simulant based on the composition data for tank AP-101, as given in a WTP Test Specification [47], was used as the basis for ORPLG glass formulations. The base waste composition incorporates TFCOUP [48] data, actual waste analysis data, and WTP flow sheet information. The sodium concentration in the simulant includes a $2.5 \%$ increase to account for sodium additions in pretreatment $[13,49]$. The nominal concentration, expressed in terms of the sodium molarity, was estimated on the basis of melter feed rheology tests on similar formulations $[50,51]$. The concentration of the simulant used in DM10 melter tests was 8.45 Molar sodium.

The nominal simulant formulation is given in Table 2.31. The LAW AP-101 simulant is a solution of predominantly aluminum, sodium, potassium, nitrate, nitrite, carbonate, and sulfate. Preparation of the waste simulant and melter feed were done in a manner similar to that for ORPLA simulant, which is described in Section 2.1.1.

\subsubsection{Region G (ORPLG) Glass Formulation}

Glass formulation development for Region G (ORPLG) was based on the composition of the LAW AP-101 waste stream. The objective was to develop a glass formulation that can accommodate a minimum waste loading of $25.41 \mathrm{wt} \%$. The waste components that are important 
in formulating glasses for this waste are $\mathrm{Na}_{2} \mathrm{O}(71.67 \mathrm{wt} \%), \mathrm{K}_{2} \mathrm{O}(19.61 \mathrm{wt} \%)$, and $\mathrm{SO}_{3}$ (1.39 wt\%). The high alkali content of the waste from a combination of $\mathrm{Na}_{2} \mathrm{O}$ and $\mathrm{K}_{2} \mathrm{O}$ is the primary challenge in glass formulation. While sulfate loading in the glass is not very high, the effect of high alkali content from a combination of $\mathrm{Na}_{2} \mathrm{O}$ and $\mathrm{K}_{2} \mathrm{O}$ on sulfate solubility is not well understood. Target and analyzed compositions of the ORPLG glasses are given in Table 2.32. ORPLG glasses were initially formulated with progressively higher waste loadings. The waste loading increases were designed such that $\mathrm{Na}_{2} \mathrm{O}$ loadings in the glasses increased from $18.5 \mathrm{wt} \%$ to $21.5 \mathrm{wt} \%$ in steps of $0.5 \mathrm{wt} \%$ at lower $\mathrm{Na}_{2} \mathrm{O}$ concentrations and in steps of $0.25 \mathrm{wt} \%$ at the higher $\mathrm{Na}_{2} \mathrm{O}$ concentrations. All of the waste components increased with waste loading, with $\mathrm{K}_{2} \mathrm{O}$ increasing from $5.06 \mathrm{wt} \%$ to $5.88 \mathrm{wt} \%$ as the $\mathrm{Na}_{2} \mathrm{O}$ concentration increased from $18.5 \mathrm{wt} \%$ to $21.5 \mathrm{wt} \%$. The additive blend was kept similar to those selected for ORPLA20, keeping $\mathrm{ZrO}_{2}+\mathrm{SnO}_{2}$ between 8.5 and $9 \mathrm{wt} \%$ for all but one of the glasses, and silica above 40.5 $\mathrm{wt} \%$. $\mathrm{CaO}$ and $\mathrm{Al}_{2} \mathrm{O}_{3}$ concentrations were decreased in an attempt to improve the performance on VHT, especially in the presence of high $\mathrm{K}_{2} \mathrm{O}$ concentrations [60]. Since VHT was a property of prime concern, it was measured for all samples before the selection of samples for K-3 corrosion tests. In order to reduce K-3 refractory corrosion, $\mathrm{Cr}_{2} \mathrm{O}_{3}$ was kept at a concentration of $\sim 0.6 \mathrm{wt} \%$ in all of the glasses. The sulfate solubilities were generally higher in the glasses with higher waste loading but VHT alteration rates rose sharply as the $\mathrm{Na}_{2} \mathrm{O}$ concentration exceeded $20.5 \mathrm{wt} \%$. At the $20.5 \mathrm{wt} \% \mathrm{Na}_{2} \mathrm{O}$ concentration, the glass also contains $5.61 \mathrm{wt} \% \mathrm{~K}_{2} \mathrm{O} . \mathrm{Fe}_{2} \mathrm{O}_{3}$ was not used as a glass former additive in any of the glasses. In two of the glasses (ORPLG5 and ORPLG11) $\mathrm{MgO}$ also was removed as an additive so that $\mathrm{Fe}_{2} \mathrm{O}_{3}$ from the $\mathrm{MgO}$ source, olivine, could be avoided. In glass ORPLG12, $2 \mathrm{wt} \% \mathrm{P}_{2} \mathrm{O}_{5}$ was added with a corresponding decrease in the $\mathrm{ZrO}_{2}$ concentration, which led to much increased VHT alteration rate.

Target and analyzed compositions of the ORPLG glasses are given in Table 2.32. Testing and analysis of the glasses followed the same methods used for ORPLA glasses, which are described in Section 2.1.2. As is evident from the table, the target and analyzed compositions show good agreement. Glass samples were heat treated for 20 hours at $950^{\circ} \mathrm{C}$ and evaluated for secondary phases. Observations of the as-melted, and heat treated glasses are given in Table 2.33. All of the as-melted glasses appeared clear with small amounts $(0.2 \mathrm{vol} \%$ or less $)$ of crystals. The heat treated glasses also showed little crystallization $(0.3 \mathrm{vol} \%$ or less $)$.

The sulfate solubilities of the ORPLG glass compositions were assessed by batch saturation tests. The batch saturation tests are described in Section 2.1.2 and the results of the tests are given in Figure 2.1 and Table 2.34. The sulfate solubilities of the ORPLG glasses varied from 0.36 to $0.49 \mathrm{wt} \%$ by batch saturation tests and generally increased with increased waste loading. In addition to batch saturation tests, the sulfate solubility of the ORPLG9 glass composition was determined by gas bubbling. Two samples of ORPLG9, one with 0.59 wt $\%$ $\mathrm{Cr}_{2} \mathrm{O}_{3}$ and another with $1.0 \mathrm{wt} \% \mathrm{Cr}_{2} \mathrm{O}_{3}$, were used in the measurements. Results of these tests are given Figure 2.6 along with the results from some earlier tests on similar glasses developed for ORP. The sample with $0.59 \mathrm{wt} \% \mathrm{Cr}_{2} \mathrm{O}_{3}$ showed a sulfate solubility of $0.65 \mathrm{wt} \%$ and the sample with $1.0 \mathrm{wt} \% \mathrm{Cr}_{2} \mathrm{O}_{3}$ showed sulfate solubility of $0.55 \mathrm{wt} \%$. More interesting is the observation that the onset of a secondary sulfate layer occurred at an $\mathrm{SO}_{3}$ concentration of about $0.3 \mathrm{wt} \%$ in the sample with $0.59 \mathrm{wt} \% \mathrm{Cr}_{2} \mathrm{O}_{3}$, whereas it occurred at an $\mathrm{SO}_{3}$ concentration of less than 
$0.2 \mathrm{wt} \%$ in the sample with $1.0 \mathrm{wt} \% \mathrm{Cr}_{2} \mathrm{O}_{3}$. The implications of this observation are discussed later in Section 5.0.

VHT and PCT results are summarized in Table 2.35 and illustrated in Figures 2.2 and 2.3. All twelve glasses met the PCT release limit, but the VHT alteration rate limit was reached in ORPLG9 $\left(21 \mathrm{wt} \% \mathrm{Na}_{2} \mathrm{O}+5.75 \mathrm{wt} \% \mathrm{~K}_{2} \mathrm{O}\right)$ and exceeded in ORPLG10 (highest waste loading) and ORPLG12 (with added $\mathrm{P}_{2} \mathrm{O}_{5}$ ). The viscosities and electrical conductivities of eleven of the ORPLG glasses at select temperatures are given in Table 2.36. All of the viscosities and electrical conductivity values are in the acceptable range for processing. Similar to ORPLA glasses, the ORPLG glasses were designed to have viscosities towards the higher end of the acceptable range in order to reduce refractory corrosion. Eight ORPLG glasses with the higher waste loadings $(>27.2 \mathrm{wt} \%)$ were tested for their K-3 corrosion characteristics. K-3 refractory corrosion test results for these glasses are given in Table 2.37 and Figure 2.4. Only one of the glasses, ORPLG11 (highest waste loading) had clearly unacceptable K-3 corrosion characteristics with a neck loss of 0.06 inches. The depth of the reaction zone into the K-3 coupon is fairly high in these samples, especially ORPLG9. This has been observed before with low viscosity glasses and glasses containing $\mathrm{Li}_{2} \mathrm{O}$, but not in the ORPLG-type of glasses. It is likely that this could impact melter life but further detailed K-3 corrosion studies will be needed to determine the effect of very high alkali content from a combination of $\mathrm{Na}_{2} \mathrm{O}$ and $\mathrm{K}_{2} \mathrm{O}$ on $\mathrm{K}-3$ corrosion.

Of the twelve ORPLG glass formulations tested, ORPLG7 and ORPLG8 are formulations with high waste loading that also met all processing and product quality requirements. Those were, therefore, recommended by VSL/EnergySolutions for DM10 melter tests. However, ORP selected ORPLG9 for the melter tests in order to determine the processing characteristics of a glass formulation that is at the limit of the acceptable range for one or more properties. The selected glass, ORPLG9, has a VHT alteration rate of $41-50 \mathrm{~g} / \mathrm{m}^{2} /$ day as compared to the limit of $50 \mathrm{~g} / \mathrm{m}^{2} /$ day and showed a K-3 neck corrosion of 0.038 inches versus the limit of 0.040 inches. The measured properties of the glass ORPLG9 are compared to the ILAW performance requirements $[53,54]$ in Table 2.38. Density and glass transition temperature measurements and canister centerline cooling (CCC) heat treatments were not conducted on ORPLG9 crucible glass, but the density was measured on the melter glass and was found to be well below the limit of $3.7 \mathrm{~g} / \mathrm{cc}$. Examination of cooled ORPLG9 glass samples from the melter showed little crystallization, indicating that the glass is unlikely to show substantial crystallization on CCC heat treatment.

The composition of the ORPLG9 glass used in melter tests is given in Table 2.39 along with the oxide contributions from the LAW AP-101 waste simulant and from the glass former additives. The simulant was prepared with no $\mathrm{SO}_{3}$ and the sulfur concentration was increased in steps during the melter tests by adding the appropriate amounts of $\mathrm{Na}_{2} \mathrm{SO}_{4}$ and $\mathrm{NaOH}$ to the feed. The melter feed was prepared at a $\mathrm{Na}_{2} \mathrm{O}$ concentration of $20.21 \mathrm{wt} \%$ in order to accommodate $\mathrm{Na}_{2} \mathrm{SO}_{4}$ and $\mathrm{NaOH}$ additions, without increasing the $\mathrm{Na}_{2} \mathrm{O}$ concentration above $21.0 \mathrm{wt} \%$. The types and amounts of glass former additives used to prepare the melter feed along with the target feed properties are given in Table 2.40a. The glass former additives are the same as those planned for use at the WTP, with the exception of chromium and tin, which would be 
new additives. The amounts of $\mathrm{Na}_{2} \mathrm{SO}_{4}$ and $\mathrm{NaOH}$ added to the feed to obtain $21.0 \mathrm{wt} \% \mathrm{Na}_{2} \mathrm{O}$ and 0.0 to $0.3 \mathrm{wt} \% \mathrm{SO}_{3}$ are given in Table $2.40 \mathrm{~b}$.

\subsection{Sugar Additions}

With high nitrate feeds, the addition of reductants is necessary in order to control melt foaming. Sugar, which was used for this purpose at West Valley, has also been selected as the baseline reductant for the WTP. The amount of sugar required increases with the amount of nitrates present in the feed and decreases with the amount of waste organics present in the feed, which themselves act as reductants. Excessive additions of reductants can be deleterious, leading to over-reduction of the melt and formation of sulfides and molten metals. Consequently, the oxidants and reductants in the feed must be suitably balanced. The basis for achieving this balance was developed by VSL and EnergySolutions for the vitrification of high-sodium-nitrate feeds at Savannah River's M-Area and has been successfully applied to the processing of a wide variety of simulated WTP feeds over the past six years. In developing this approach, we elected to conservatively adopt the most reducing potential reaction as the basis for the definition of a "sugar" or stoichiometric ratio of 1.0 as a result of concerns for over-reducing the melt. Such a reaction, using sodium salts as an example, is:

$$
\mathrm{C}_{12} \mathrm{H}_{22} \mathrm{O}_{11}+8 \mathrm{NaNO}_{3}=8 \mathrm{CO}_{2}+4 \mathrm{CO}+4 \mathrm{~N}_{2}+11 \mathrm{H}_{2} \mathrm{O}+4 \mathrm{Na}_{2} \mathrm{O}
$$

Fundamentally, the basis that is selected is simply a convention, since the precise stoichiometry of the reactions involved is neither known nor constant under the conditions prevailing in the melter. However, with this convention, a sugar ratio of 1.0 corresponds to one mole of sucrose per eight moles of nitrate or, more generally, 1.5 moles of organic carbon per mole of nitrate. It is then expected that significantly less sugar than this will be required in practice. The empirically determined amount required to successfully control melt foaming without significantly reducing the glass melt was found to correspond to a ratio of 0.5 when any nitrites present were counted as nitrates (i.e., 0.75 moles of organic carbon per mole of nitrate + nitrite). This approach has been employed for all WTP melter testing. It is, however, expected that slight variations around the nominal value of 0.5 may be necessary to account for differences in the reducing power of waste organics in comparison to sugar, particularly for LAW streams that are high in organics.

As an example, the calculation of the amount of sugar needed for the present LAW AN-105 (Envelope A) feed to achieve a sugar ratio of 0.5 proceeds as follows:

- One liter of 8 Molar sodium simulant contains 1.857 moles of nitrite and 2.048 moles of nitrate, giving a total of 3.905 moles of NOx (see Table 2.1)

- The required total amount of organic carbon for a sugar ratio of 0.5 is $3.905 \times 0.75=2.929$ moles

- One liter of simulant contains 0.174 moles of organic carbon (see Table 2.1)

- Therefore, $2.929-0.174=2.755$ moles of organic carbon must be added. 
Since the molecular weight of sucrose is $342 \mathrm{~g}, 2.755 \times 342 / 12=78.5 \mathrm{~g}$ sugar must be added per liter of simulant, as shown in Table 2.10.a.

\subsection{Analysis of Melter Feed Samples}

\subsubsection{General Properties}

Feed samples from melter tests were analyzed to confirm physical properties and chemical composition. Samples were taken from residual composite melter feed, from individual test segments, and feed prior to adjusting the sulfur content. Sample names, sampling dates, measured properties and comparisons with feed analysis for similar waste streams $[2,3,6,22$, 24, 26, 61-63] are provided in Table 2.41. The average measured glass yield for the melter samples was less than $6 \%$ below the target values (on a mass per unit mass basis) validating the use of the target value for calculating glass production rates. This small low bias for glass yield and density is observed in most LAW feeds due perhaps to high estimates in the purity of the additives as well as water added during the transfer of feed [64]. An exception is the glass conversion ratio and water content measured for the Test A sample that is well below the target values. The difference in the glass conversion ratio calculated from the total feed processed (224.1 kg, see Table 3.1) and the total glass produced $(97.9 \mathrm{~kg}$, see Table 4.1$)$ is only $7 \%$, suggesting a sampling bias. In subsequent tests, more feed samples were taken during each test to better distinguish such sampling biases. In all but the AN-107 (Sub-Envelope C1) waste, the measured $\mathrm{pH}$ is higher in the samples from the current tests since much of the additional sodium is introduced to the feed as sodium hydroxide. Measured feed densities and feed solids content in the current tests are similar to those measured in previous tests with the same wastes except for AZ-102 (Sub-Envelope B2 waste), in which the samples from the current tests have higher solids content.

\subsubsection{Chemical Composition}

The chemical compositions of the feed samples were determined by first making a glass from the feed sample via crucible melt. The glass was subsequently crushed and analyzed directly by XRF. The boron and lithium oxide target values were used for normalizing the XRF data since their concentration was not determined by XRF. The XRF-analyzed compositions of the feed samples are provided in Table 2.42 . The results generally show good agreement with the target composition for the major components. Of the oxides with target concentrations of one percent or greater, the XRF values had deviations of less than $10 \%$ except for vanadium and tin, which had a high bias between 8 and 14.34 percent, zirconium which deviated in some samples due presumably to settling in the feed tank or sampling container, and calcium in the Test A feed. The deviations in tin and vanadium were also observed in the product glasses and may be attributable to a potential analytical bias for these elements using XRF [2, 6, 7, 64] (see Section 4.1). The surplus in calcium observed in the feed sample was not observed in the product glass and therefore is likely attributable to sampling deviations. 
A surplus of sodium was observed in the feed samples as well as the product glasses from Tests D1 - D4. Although the sodium surplus was less than ten relative percent, the absolute surplus of sodium was on the order of one weight percent oxide, which has the potential to degrade the chemical durability of the product glass. A source of feed contamination was identified and Test D4 was repeated with new chemicals as Test D5.

Volatile minor elements such as sulfur and chlorine are, as expected, below target due to loss during crucible melting. In samples taken prior to the addition of sulfur, small amounts of sulfur were measured in the feed as a contaminant and indicate a lower bound on the amount of sulfur in that feed since an indeterminate amount is volatilized during crucible melting. The amount of sulfur contamination in the feed was not taken into account in the amount of sodium sulfate added to the feed and therefore the actual amount in the feed may be slightly over the target concentration. The amount of sulfur in the feed, which is important for determining sulfur retention in the glass, is assumed to be the target concentration; the target is calculated, checked, and the corresponding amounts of chemicals are weighed out using calibrated balances. Titanium oxide was measured in the feed samples from one to three tenths of a weight percent, even though it was not included in the target composition. Similar observations were made in previous tests with LAW melter feeds [7, 10, 11, 17-19, 64] and is due to its presence as a contaminant in the glass forming additives, most notably kyanite [2]. Iodine was measured in the feed samples at around a tenth of a weight percent as a result of its presence as an impurity in the tin additive used. Common elements such as chromium, iron, and phosphorus, which are typical impurities in bulk chemicals, are over-represented when the constituent is a minor component. Higher measured concentrations for these common elements may also be attributable to uncertainties at these low concentrations. 


\section{SECTION 3.0 DM10 TESTS}

Melter tests were conducted on the DM10 with the LAW simulants from 10/15/08 to $10 / 23 / 08$ and $1 / 5 / 09$ to $1 / 16 / 09$ to determine the maximum sulfur concentration that can be processed without forming secondary phases for each of the four compositional regions. These tests produced almost half a metric ton of glass from about a metric ton of feed. Tables 3.1 - 3.4 provide summaries of the DM10 tests, including run times, the amount of sulfur in the feed, the amount of feed processed, the amount of feed sulfur retained in the glass product, observations of secondary phases, key processing parameters, and measured concentrations of gaseous species. The tests, listed in the order in which they were performed, were as follows:

- Test A: Four nominally 14-hour feeding segments with LAW ORP S8AN105 simulated wastes with a $\mathrm{Na}_{2} \mathrm{O}$ concentration of $24 \mathrm{wt} \%$ in the ORPLA20 target glass composition. Segments tested $\mathrm{SO}_{3}$ concentrations of $0.5,0.7,0.8$, and $0.9 \mathrm{wt} \%$ in the glass product (assuming total retention).

- Test D: Five nominally 14-hour feeding segments with LAW ORP S8AN102 simulated wastes with a $\mathrm{Na}_{2} \mathrm{O}$ concentration of $22 \mathrm{wt} \%$ in the ORPLD6 target glass composition. Segments tested $\mathrm{SO}_{3}$ concentrations of $0.9,1.1,1.2$, and $1.3 \mathrm{wt} \%$ in the glass product (assuming total retention). The sulfur concentration of $1.2 \mathrm{wt} \% \mathrm{SO}_{3}$ was tested a second time with a corrected sodium content.

- Test F: Six nominally 14-hour feeding segments with LAW ORP S5AZ102 simulated wastes with a $\mathrm{Na}_{2} \mathrm{O}$ concentration of $12 \mathrm{wt} \%$ in the ORPLF7 target glass composition. Segments tested $\mathrm{SO}_{3}$ concentrations of $0.8,1.2,1.4,1.5$ and $1.6 \mathrm{wt} \%$ in the glass product (assuming total retention). The sulfur concentration of $1.4 \mathrm{wt} \% \mathrm{SO}_{3}$ was tested a second time to add additional confidence to the results.

- Test G: Three nominally 14-hour feeding segments with LAW ORP S8AP101 simulated wastes with a $\mathrm{Na}_{2} \mathrm{O}$ concentration of $21 \mathrm{wt} \%$ in the ORPLG9 target glass composition. Segments tested $\mathrm{SO}_{3}$ concentrations of $0.2,0.4$, and $0.5 \mathrm{wt} \%$ in the glass product (assuming total retention).

The principal objective of these tests was to determine, for each feed, the maximum amount of sulfur that can be fed into the melter without forming secondary sulfate phases. The bubbling rate was adjusted to maintain target glass production rates between 2250 and $2500 \mathrm{~kg} / \mathrm{m}^{2} /$ day with a complete cold cap. Test segment durations of 12 to 17 hours were selected since, at the target glass production rate, this provided three melt pool turnovers $(24 \mathrm{~kg})$ for each sulfur concentration. Sugar was added to the feed at a stoichiometric carbon ratio of 0.5 for all of the melter tests. At the end of each test segment, dip samples were taken to detect the presence of a separate sulfur phase on the glass pool surface. The melt surface was considered free of a sulfate layer if no visible secondary sulfate phases were observed on any of the three dip 
samples. If a sulfate layer was detected on the melt surface, the glass pool was bubbled until the dip samples indicated that the sulfate layer had dissipated prior to commencing the subsequent test segment.

\subsection{DM10 System Description}

\subsubsection{Feed System}

The feed container is mounted on a load cell for weight monitoring and is stirred continuously except for periodic, momentary interruptions during which the weight is recorded. The material in the feed container is constantly recirculated, which provides additional mixing. The recirculation loop extends to the top of the melter where feed is diverted from the recirculation loop through a peristaltic pump into the melter through a Teflon-lined feed line and vertical water-cooled feed tube. A diverter valve permits direction of the feed stream either to the melter or to a sampling vessel.

\subsubsection{Melter}

The DM10 system used for this work is a ceramic refractory lined melter, which includes two Inconel 690 plate electrodes that are used for joule-heating of the glass pool and a bubbler for agitating the melt. Glass is discharged from the melter using an air-lift system. The melt pool has a surface area of $0.021 \mathrm{~m}^{2}$ and typically contains about $8 \mathrm{~kg}$ of glass. The plenum volume is 19.5 liters at the nominal glass level. Inconel 690 thermowells were custom fabricated and installed in the DM10 for the current tests since in previous tests, thermowells made from Inconel 601 experienced rapid corrosion in tests with high-alkali, high-sulfur feeds [5].

\subsubsection{Off-Gas System}

For operational simplicity, the DM10 is equipped with a dry off-gas treatment system involving gas filtration operations only. Exhaust gases leave the melter plenum through a film cooler device that minimizes the formation of solid deposits. The film cooler air has constant flow rate and its temperature is thermostatically controlled. The geometry of the transition line (between the melter and the first filtration device) conforms to the requirements of the 40-CFR-60 air sampling techniques. Immediately downstream of the transition line are cyclonic filters followed by conventional pre-filters and HEPA filters. The temperature of the cyclonic filters is maintained above $150^{\circ} \mathrm{C}$ while the HEPAs are held above $100^{\circ} \mathrm{C}$ to prevent moisture condensation. The entire train of gas filtration operations is duplicated and each train is used alternately. An induced draft fan completes the system. The sampling location for gaseous species monitored by FTIR is immediately downstream of the draft fan. 


\subsection{DM10 Test Conditions}

Target processing conditions, including bubbling rate adjusted to maintain a target production rate between 2250 and $2500 \mathrm{~kg} / \mathrm{m}^{2} /$ day, a melt pool temperature of $1150^{\circ} \mathrm{C}$, and a complete cold cap were achieved throughout the majority of the melter tests. Test segment average production rates ranged from 1950 to $2678 \mathrm{~kg} / \mathrm{m}^{2} /$ day. The target rate could not be reached in the last two segments of Test $\mathrm{G}$ due to foaming of the glass. Similar problems were observed in previous DM10 tests with LAW wastes which used tin and vanadium as additives at oxide concentrations greater than one and a half weight percent and relatively high melt viscosity [7]. Test segment average bubbling rates ranged from 1.8 to 4.1 liters per minute and were generally lower while processing the ORPLF7 (Test F) and ORPLG9 (Test G) glass formulations, the latter of which resulted from attempts to limit foaming.

The measured test segment average glass temperatures two inches from the melt pool floor were between $1151-1159^{\circ} \mathrm{C}$ for all test segments, thus indicating that the target glass temperature of $1150^{\circ} \mathrm{C}$ was achieved. Measured glass temperatures two inches higher in the glass pool were 4 to $40^{\circ} \mathrm{C}$ lower throughout testing due to the proximity to the glass surface. Average temperatures during test segment D3 were lower due to power being lost to the melter for about 2 hours (feeding was also discontinued during this period). Each test segment started with the melt pool at the nominal operating temperature of $1150^{\circ} \mathrm{C}$. Typical plots of DM10 melter temperatures are given in Figures 3.1.a and 3.1.b. The plots are for the first and the last complete tests (Tests A and G). As mentioned above, the data at 2" from the melter bottom are most representative of the bulk glass temperature; these data average very close to the target of $1150^{\circ} \mathrm{C}$ and vary little during feeding periods. The measurement 4 " from the bottom is closer to the melt surface and varies by about $80^{\circ} \mathrm{C}$ as the level of the glass changes. Variations in temperatures measured at both locations were observed during idling periods used to take glass dip samples and purge the melt surface of secondary sulfate phases. In keeping with previous DM10 tests, the electrode temperatures were lower than glass pool temperatures; however, the difference was about half the 50 to $100^{\circ} \mathrm{C}$ difference observed in the previous tests. The measured test segment average plenum temperatures were well below $600^{\circ} \mathrm{C}$, indicating that a complete cold cap covered the melt pool surface throughout the tests. Typical plots of DM10 plenum temperatures are given in Figures 3.2.a and 3.2.b for the first and last complete tests conducted. Higher plenum temperatures occurred at the beginning of testing and in between test segments while the melt pool was probed for secondary sulfate phases. Unlike plenum temperature measurements on larger melters, the exposed thermocouple often gave a lower temperature reading than the thermocouple in the thermowell due to variable amounts of feed coating the exposed thermocouple.

\subsection{DM10 Test Results}

Evaluation of glass pool samples provided an indication of the tolerance of the glass formulations to sulfur at nominal melter conditions. Depictions of the target and measured sulfur contents are provided in Figures 3.3.a - 3.3.d for each of the test series. During Test A with the 
ORPLA20 target glass composition, secondary sulfate phases were observed while processing feeds targeted at 0.8 and $0.9 \mathrm{wt} \% \mathrm{SO}_{3}$ but not at 0.5 and $0.7 \mathrm{wt}^{2} \% \mathrm{SO}_{3}$; thus the sulfur saturation occurs between 0.7 and $0.8 \mathrm{wt} \% \mathrm{SO}_{3}$.

The second test series conducted with ORPLD6 target glass composition show increases in the feed and glass sulfur concentrations to a feed sulfur concentration of $1.3 \mathrm{wt} \% \mathrm{SO}_{3}$ where a secondary sulfate phase was observed. A following test segment conducted with $\mathrm{SO}_{3}$ feed concentration of $1.2 \mathrm{wt} \%$ resulted in no secondary sulfate phases; however, subsequent analysis of the glass indicated the sodium concentration of the Test D product glasses was higher than targeted (see Section 4.2 and 4.4). Therefore, after conducting several other tests with the other glass compositions, this test was repeated using feed with the proper sodium concentration and $1.2 \mathrm{wt}_{0} \mathrm{SO}_{3}$; that test showed the presence of a secondary sulfate phase. The apparent contradiction of results indicates that this glass composition is near saturation at $1.2 \mathrm{wt} \% \mathrm{SO}_{3}$ and that subtle change in concentration or transitions in the glass pool can result in secondary sulfate phases.

Secondary sulfate phases were conspicuous after the first segment of Test $\mathrm{F}$ with feed containing $1.6 \mathrm{wt} \% \mathrm{SO}_{3}$ but not in subsequent segments. A trace amount of secondary sulfate was observed after processing $1.4 \mathrm{wt} \% \mathrm{SO}_{3}$; however, since no secondary phases were observed after subsequent tests processing 1.4 and $1.5 \mathrm{wt} \% \mathrm{SO}_{3}$, the trace amount of sulfate observed after the second test segment was probably transient. The tolerance of the ORPLF7 target glass composition is therefore between 1.5 and $1.6 \mathrm{wt} \% \mathrm{SO}_{3}$ in the feed.

The most extensive secondary phases were observed during Test $G$ with the ORPLG9 target glass composition. Secondary sulfate phases were observed at the end of each test segment, even as the sulfur content of the feed was reduced from 0.5 to $0.2 \mathrm{wt} \% \mathrm{SO}_{3}$, indicating that this glass formulation has little tolerance for sulfur. The potential reasons for the very low sulfate tolerance of the ORPLG9 feed are discussed in Section 4.3.

\subsection{Gases Monitored by FTIR}

Melter emissions were monitored in each test for a variety of gaseous components, most notably carbon monoxide, ammonia, sulfur dioxide and nitrogen species, by Fourier Transform Infra Red Spectroscopy (FTIR). The off-gas system temperature is maintained well above $100^{\circ} \mathrm{C}$ beyond the sampling port downstream of the HEPA filter in order to prevent analyte loss due to condensation prior to monitoring. Test segment average concentrations of $\mathrm{NO}, \mathrm{NO}_{2}, \mathrm{CO}$, and $\mathrm{NH}_{3}$ are provided in Tables 3.1-3.4; these analytes are those that were expected to be observed during the test, based on previous work. $\mathrm{No} \mathrm{SO}_{2}$ was detected in any of the tests and therefore none is reported in the tabular data. The FTIR detection limit for sulfur dioxide is relatively high ( 5 ppmv) and, therefore, measurable quantities are only observed with high sulfur containing feeds and in systems with minimal dilution of the melter exhaust by film cooler or process air. The most abundant nitrogen species monitored was NO, which is consistent with previous tests $[2-7,10,11,18-27,43]$ in which nitrates and nitrites were abundant in the feed. The measured

concentrations of most monitored components increase with increasing feed nitrogen oxide 
content and feed rates. Nitrogen oxide, carbon monoxide, and ammonia concentrations are significantly lower during Test F with the feed containing LAW AZ-102 simulant, as a result of the low nitrate and consequently lower organic content in the feed. 


\section{SECTION 4.0 DM10 GLASS PRODUCTS}

Almost half a metric ton of glass was produced in these tests. The glass was discharged from the melter periodically into square steel cans using an airlift system. The discharged product glass was sampled at the end of each test by removing sufficient glass from the top of the cans for total inorganic analysis. Care was exercised during sampling of each can to identify and segregate any potential secondary phases; however, no secondary phases were observed in the discharged glass. Product glass masses, discharge date, and analysis performed are listed in Table 4.1. Glass samples were also obtained by dipping a rod into the glass pool at the beginning and end of each test. These "dip samples" underwent visual examination to detect the presence of a separate sulfate phase on the glass pool surface.

\subsection{Compositional Analysis}

Glass discharge samples were crushed and analyzed directly by XRF. The target values for boron and lithium oxides, which are not determined by XRF, were used for normalizing the $\mathrm{XRF}$ data to $100 \mathrm{wt} \%$. The XRF-analyzed compositions of all discharged glass samples are provided in Tables 4.2. Results of XRF analysis of glass samples are compared with the target composition and results of DCP analysis of solutions generated by microwave aided acid dissolution in Tables 4.3 and 4.4, respectively. Samples were selected for this comparison from the end of tests with the highest sulfur concentrations without forming secondary phases on the melt pool surface, and from multiple test segments if the test segments for a given composition were not conducted consecutively. The majority of the XRF analysis results compare favorably to their corresponding target values and feed sample analysis (see Section 2.6.2). The concentrations of vanadium oxide were 10 to 13 relative percent above target concentrations. In all but one analysis (for tin), the concentrations of chromium, tin, and vanadium measured by the DCP method were closer to target values, suggesting that the XRF may have a high bias for these elements. Above target concentrations of vanadium were also measured in previous tests $[2,6,7$, 64]. Similar to the feed samples, zirconium oxide concentrations were up to fifteen relative percent below target concentrations, due presumably to chemical purity or settling of zircon crystals in the feed tank. Iron oxide concentrations were above the low target concentrations due to the ubiquity of the element in bulk chemicals. Elements not included in the target glass compositions, including iodine, manganese, nickel, lead, phosphorus, titanium, tin, and vanadium were observed in the product analysis as a result of corrosion of melter components, carry-over from previous tests, and trace contamination of additives.

The higher than target concentration of sodium observed in the feed samples from Test Segments D1-D4 (see Section 2.6.2) is also observed in the glass product. The surplus in these samples of about one and a third absolute percent is not present in glass samples from Test Segment D5 after a new batch of chemicals was used in feed formulation. Measured boron and 
lithium concentrations were within five percent of the target, validating the use of the target value for normalizing the XRF data. Agreement between the two analytical methods was excellent, except for low sodium values obtained from the DCP analysis, which is due in part to a low-bias for sodium [6, 64]; previous experience indicates that the XRF results are more reliable in this regard. Also silicon results are lower by the DCP method due perhaps to its incomplete dissolution during sample preparation.

Compositional trends of the major and select oxides during the tests are shown in Figures 4.1.a.-4.8.b. They illustrate the differences between the tested compositions and closeness to target over the course of the tests. These depictions also show the sampling and analytical variations attributable to the methods used; for example, potassium shows minimal variability whereas zirconium can vary by about half a weight percent in sequential glass discharges. Discontinuities are readily observed in the changes in sulfur, calcium, zirconium, magnesium, and potassium between the fourth and fifth segments for Tests D and F as a result of the latter segments being conducted after processing several other compositions during the intervening interval. The glass compositions were held constant during each testing sequence and therefore the most significant changes were observed during the first test segment. These changes for additives calcium, magnesium, vanadium, and tin as well as the waste components sodium, potassium, and chlorine are evident in the plotted data.

As intended, sodium spanned a range of twelve weight percent oxide, which was greater than for any other element. The plotted sodium data show a close approximation to target for four of the compositions with small deficiencies during Test A and a small excess of sodium during the first four segments of Test D, which was remedied in the fifth segment by using new batches of reagents. High analytical bias is shown for the additives vanadium and tin as well as deficiencies in aluminum and zirconium in some tests are observed in the plotted data. Chlorine loss during these tests was 15 to $30 \%$, which is less than the near-50\% loss of chlorine from the glass at target concentrations greater than 0.3 weight percent $[7,25,52]$ found in previous tests. This difference may be due to the higher concentration of sodium in the target glasses and possibly higher chlorine contamination of feed constituents. Complete sampling and analysis of melter exhaust commonly conducted on larger melters [2-6, 10, 11, 18-27, 61-63, 65] is required for a more accurate assessment of elemental volatility and mass balance calculations. Measured chromium oxide concentrations were about 0.25 weight percent above target concentrations during Tests A, D, and F, and about 0.3 weight percent above target during Test G. Surpluses of chromium in the feed were about 0.2 weight percent for feed samples from Tests $\mathrm{A}$ and $\mathrm{F}$, and 0.12 weight percent for feed samples from Tests $\mathrm{D}$ and $\mathrm{G}$. The difference between the feed and product glass concentration indicates that about 0.12 weight percent chromium oxide during Test $\mathrm{D}$ and 0.2 weight percent chromium oxide during Test $\mathrm{G}$ can be attributed to corrosion of melter brick and Inconel components.

\subsection{Secondary Phase Observations}

All discharged glass and glass "dip" samples taken directly from the melt pool were closely examined to document the presence or absence of secondary phases. Glass dip samples 
were obtained from three separate locations in the melt pool at the end of each test segment; these samples were collected to ascertain whether a secondary sulfate layer had formed on the surface of the glass melt in response to the feed sulfur concentration used for that test segment. Samples were also taken to ensure the melt surface was free of secondary phases prior to starting each test segment, as well as after bubbling intended to volatilize sulfur from a previously formed sulfur layer. Table 4.5 provides a listing of all of the dip samples and whether or not a separate salt phase was evident. Examples of secondary phases observed while processing three of the formulations are shown in Figures $4.9-4.11$. Notice the powdery yellow material adhering to the rod and interspersed throughout some of the glass, both of which are indicative of a sample taken from a melt pool with a sulfate layer on the surface. Some of the sulfur layers that formed on the glass pool surface were extensive. Several hours of melt pool bubbling, and in some instances water feeding, were required to rid the melt pool of secondary phases.

\subsection{Comparison of the Properties of Crucible and Melter Glasses}

Samples of DM10 discharge glasses and crucible melts for each waste composition were subjected to the PCT leaching procedure. When possible, samples were collected from melter test segments during which the highest sulfate concentrations that did not result in secondary sulfate phases were processed. The PCT releases of the melter glasses, along with those of crucible glasses with the same target compositions, are given in Table 4.6 and compared in Figure 4.12. PCT releases of all of the melter and crucible glasses are well below the WTP contract limit mass loss of $2.0 \mathrm{~g} / \mathrm{m}^{2}$ for $\mathrm{B}, \mathrm{Na}$ and $\mathrm{Si}$. The PCT results for melter and crucible glasses are similar, with the differences within expected variations based on round robin PCT testing of an Argonne National Laboratory-Low Activity Reference Material (ANL-LRM) glass sample [66].

VHT results for the melter and corresponding crucible glasses with the same target composition are given in Table 4.7. VHT alteration rates calculated by two different methods are given in Table 4.7. One method involves direct measurement of the alteration layer thickness, while the other involves measurement of the remaining glass. The VSL Standard Operating Procedure (SOP) for VHT measurement specifies that when the alteration layer thickness is greater than $100 \mu \mathrm{m}$, it should be determined based on the remaining glass. This is because when the alteration layer thickness is sufficiently large, measuring the dimensions of the remaining glass and subtracting it from the original sample dimensions gives a better estimate of the thickness of the altered layer. A direct measurement of the layer thickness can provide erroneous values because the altered layer may have expanded, thus giving a larger value than the actual thickness of the altered part of the glass sample, particularly for thick layers. The VHT alteration rates given in Section 2 are mostly based on the measurement of the remaining glass. The VHT alteration rates for the melter glass samples are all higher than those for the corresponding crucible melt samples. One of the reasons for the difference is the presence of bubbles and cracks in the melter glass samples, which are absent in the crucible glass samples. Excessive alteration around bubbles and cracks in melter glass samples as compared to the crucible glasses can be seen in Figures 4.13 to 4.16. Another potential reason is that the melter glasses prepared from slurry feeds are likely to contain more $\mathrm{OH}$ groups in the structure as compared to the crucible 
melts prepared from dry chemicals, which would also likely lead to higher VHT alteration rates. All but one of the samples showed VHT alteration rates that are less than the WTP contract limit of $50 \mathrm{~g} / \mathrm{m}^{2} /$ day. The exception is for the VHT coupon of the melter glass sample 10A-G-43B, with the ORPLG9 composition, which was almost completely altered. As is evident from Figure $4.16 \mathrm{~b}$, bubbles and cracks in this melter glass sample clearly increased the VHT alteration. The fact that the ORPLG9 melter glass sample failed the VHT alteration rate limit of $50 \mathrm{~g} / \mathrm{m}^{2} / \mathrm{day}$ is not surprising because the crucible melt sample of the ORPLG9 composition showed a VHT alteration rate in the range of $41-50 \mathrm{~g} / \mathrm{m}^{2} /$ day and the uncertainty associated with VHT measurements is about $\pm 31 \%[60]$.

The densities of both the as-discharged glass samples and remelted samples were also measured. Some of the discharge glass samples contained gas bubbles and therefore density measurements were made on the as-discharged and remelted samples in order to get an estimate of the amount of bubbles in the as-discharged glasses. The remelted glass samples were almost free of bubbles. The results of the measurements are given in Figure 4.17. As can be seen in the figure, ORPLG9 glass contained the most bubbles, with lesser amounts in ORPLA20 and ORPLD6, and the least in ORPLF7. The measured densities are all below the limit of $3.7 \mathrm{~g} / \mathrm{cc}$. The largest difference in density between the as-discharged and remelted melter glass samples was for the ORPLG9 composition, where the density of the remelted glass sample was about 5\% higher than that of the as-discharged sample. 
The Catholic University of America Vitreous State Laboratory
Glass Formulation Development and DM10 Melter Testing with ORP LAW Glasses

Final Report, VSL-09R1510-2, Rev. 0

\section{SECTION 5.0 SUMMARY AND CONCLUSIONS}

Several tests were conducted on the DM10 vitrification system to evaluate newly developed LAW glass formulations intended to maximize waste loading. Glass formulations for the melter tests were selected on the basis of a series of crucible melts that were prepared and characterized. Glasses were formulated for four different waste streams, maximizing sodium content at progressively higher target sulfur contents while meeting requirements for product quality (PCT and VHT), refractory corrosion characteristics, and processing properties. The results from this work, in combination with our previous work in this area, provides ORP with a broad basis of glass formulation and characterization data from which to assess the likely enhancements in LAW loadings that should be possible in the WTP LAW design with the current product quality and processability constraints. Such enhancements provide the potential for significant cost and schedule savings. Implications of the results from this work for the WTP and recommendations for future work are provided at the end of this section.

The GFC additives that have been used previously in the LAW glasses are $\mathrm{Al}_{2} \mathrm{O}_{3}, \mathrm{~B}_{2} \mathrm{O}_{3}$, $\mathrm{CaO}, \mathrm{Cr}_{2} \mathrm{O}_{3}, \mathrm{Fe}_{2} \mathrm{O}_{3}, \mathrm{Li}_{2} \mathrm{O}, \mathrm{MgO}, \mathrm{SiO}_{2}, \mathrm{SnO}_{2}, \mathrm{TiO}_{2}, \mathrm{~V}_{2} \mathrm{O}_{5}, \mathrm{ZnO}$ and $\mathrm{ZrO}_{2}$. For the present work, $\mathrm{Fe}_{2} \mathrm{O}_{3}$ and $\mathrm{TiO}_{2}$ were not used as glass former additives, instead focusing on $\mathrm{SnO}_{2}$ and $\mathrm{V}_{2} \mathrm{O}_{5}$ additions to improve waste loadings while maintaining acceptable glass properties. $\mathrm{ZnO}$ is added at concentrations in the range of 2 to $3 \mathrm{wt} \%$ mainly to reduce corrosion of $\mathrm{K}-3$ refractory by the glass. It is also beneficial in reducing corrosion of Inconel components. $\mathrm{MgO}$ and $\mathrm{Fe}_{2} \mathrm{O}_{3}$ were previously added to reduce K-3 corrosion and as an allowance for their presence as impurities in other GFCs. In the present work, $\mathrm{Fe}_{2} \mathrm{O}_{3}$ was not used as a glass former additive, and a number of glasses were formulated without either $\mathrm{Fe}_{2} \mathrm{O}_{3}$ or $\mathrm{MgO}$, so that $\mathrm{Fe}_{2} \mathrm{O}_{3}$ as an impurity from the $\mathrm{MgO}$ source, olivine, can also be avoided. From the test results, it is not clear whether removal of $\mathrm{Fe}_{2} \mathrm{O}_{3}$ and/or $\mathrm{MgO}$ adversely affected K-3 refractory corrosion, but refractory corrosion was a significant issue for the high-waste-loading, high-alkali formulations. In general, components such as $\mathrm{SiO}_{2}, \mathrm{SnO}_{2}$, and $\mathrm{ZrO}_{2}$ improve the chemical durability of the glass, including performance on the PCT and VHT. Of these, $\mathrm{ZrO}_{2}$ and $\mathrm{SnO}_{2}$ are the most effective in reducing VHT alteration rates. These components usually are also effective in reducing corrosion of both $\mathrm{K}-3$ and Inconel by the glass. Even though $\mathrm{Al}_{2} \mathrm{O}_{3}$, in general, tends to improve chemical durability, its substitution by other components such as $\mathrm{SiO}_{2}, \mathrm{SnO}_{2}$, and $\mathrm{ZrO}_{2}$ can be beneficial in reducing VHT alteration rates. Increases in $\mathrm{B}_{2} \mathrm{O}_{3}$ concentration can have variable effects on chemical durability and typically tend to reduce melt viscosity. $\mathrm{Li}_{2} \mathrm{O}, \mathrm{CaO}$, and $\mathrm{V}_{2} \mathrm{O}_{5}$ all are beneficial in increasing sulfate loading, with $\mathrm{Li}_{2} \mathrm{O}$ being the most effective. In general, as very high sodium glasses are formulated, the concentrations of components that reduce corrosion and improve chemical durability need to be increased. In addition, these components typically increase the viscosity of the glass melt. As relatively lower sodium and higher sulfate glasses are formulated, the concentrations of additives that increase sulfate solubility are increased. $\mathrm{Cr}_{2} \mathrm{O}_{3}$ is added solely to reduce corrosion of K-3 refractory by the glass. The addition of $\mathrm{Cr}_{2} \mathrm{O}_{3}$ has been quite successful in increasing the waste loading in high alkali LAW glasses, where K-3 refractory corrosion can limit waste loading. However, it also known that sulfate and chromate show synergistic behavior [67] and the presence of chromium can increase the tendency for secondary sulfate/chromate phase formation, which can potentially limit waste loading in LAW 
glasses that contain sulfur. We believe that this effect was observed in at least one of the glasses tested, ORPLG9, as discussed below. It should be noted that the effect of the addition of each of these components cannot be taken in isolation. Each has to be considered in combination with the other glass former additives, the overall composition of the glass, and relevant glass melt properties such as viscosity and glass redox state. For the current work, glass formulation development and testing were designed such that the maximum achievable waste loadings could be determined for four LAW streams specified by ORP. Details of the LAW glasses selected for the current set of melter tests for the four regions, ORPLA20, ORPLD6, ORPLF7, and ORPLG9, are summarized below.

ORPLA20: The glass formulation development for Region A was based on the composition of LAW from Hanford tank AN-105. The developed glass formulation, ORPLA20, has a target waste loading of $31.6 \mathrm{wt} \%$, with target $\mathrm{Na}_{2} \mathrm{O}$ and $\mathrm{SO}_{3}$ loadings of 24.0 and $0.7 \mathrm{wt} \%$, respectively. The waste loading for the previous ORP glass developed for this LAW stream, ORPLA15 [7], had the same $\mathrm{Na}_{2} \mathrm{O}$ and overall waste loadings, but a lower $\mathrm{SO}_{3}$ loading of $0.6 \mathrm{wt} \%$. In addition, ORPLA20 shows much improved performance on the VHT as compared to ORPLA15, which was achieved by the addition of $\mathrm{SnO}_{2}$ in place of $\mathrm{Fe}_{2} \mathrm{O}_{3}$, and substitution of part of the $\mathrm{Al}_{2} \mathrm{O}_{3}$ additive with $\mathrm{SiO}_{2}$. The waste loading of $31.6 \mathrm{wt} \%$ in ORPLA20 is higher than that in the corresponding WTP LAW correlation glass, LAWE4H [52] of $27.2 \mathrm{wt} \%$, and the WTP LAW baseline glass, LAWA44 [13] of $26.0 \mathrm{wt} \%$. The nominal composition of LAW from tank $\mathrm{AN}-105$ has a $\mathrm{SO}_{4} / \mathrm{Na}$ molar ratio of $3.0 \times 10^{-3}$, which equates to an $\mathrm{SO}_{3}$ concentration of $0.18 \mathrm{wt} \%$ at a $\mathrm{Na}_{2} \mathrm{O}$ loading of $24.0 \mathrm{wt} \%$. Glass ORPLA20, which can accommodate $0.7 \mathrm{wt} \%$ $\mathrm{SO}_{3}$ at $24.0 \mathrm{wt} \% \mathrm{Na}_{2} \mathrm{O}$ loading can, therefore, be used to treat LAW AN-105 type streams with $\mathrm{SO}_{4} / \mathrm{Na}$ ratios of up to $1.16 \times 10^{-2}$.

ORPLD6: The glass formulation development for Region D was based on the composition of LAW from Hanford tank AN-102. The developed glass formulation, ORPLD6, has a target waste loading of $25.9 \mathrm{wt} \%$, with target $\mathrm{Na}_{2} \mathrm{O}$ and $\mathrm{SO}_{3}$ loadings of 22.0 and $1.2 \mathrm{wt} \%$, respectively. The waste loading for the previous ORP glass developed for this LAW stream, ORPLD1 [7], had a target waste loading of $24.9 \mathrm{wt} \%$, with target $\mathrm{Na}_{2} \mathrm{O}$ and $\mathrm{SO}_{3}$ loadings of 21.0 and $1.1 \mathrm{wt} \%$, respectively. Compared to ORPLD1, ORPLD6 has slightly higher (but still safely below the limit) VHT alteration rate and shows higher K-3 refractory corrosion. The waste loading improvement was obtained through increases in the concentrations of $\mathrm{ZrO}_{2}$ and $\mathrm{V}_{2} \mathrm{O}_{5}$ and decreases in $\mathrm{B}_{2} \mathrm{O}_{3}$ and $\mathrm{Fe}_{2} \mathrm{O}_{3}$ in the glass. The waste loading of $25.9 \mathrm{wt} \%$ in ORPLD6 is substantially higher than that in the corresponding WTP LAW correlation glass, LAWE7H [52] of $16.2 \mathrm{wt} \%$, and the WTP LAW baseline glass, LAWC35 [13] of $14.0 \mathrm{wt} \%$. The nominal composition of LAW from tank $\mathrm{AN}-102$ has a $\mathrm{SO}_{4} / \mathrm{Na}$ molar ratio of $2.1 \times 10^{-2}$, which equates to an $\mathrm{SO}_{3}$ concentration of $1.01 \mathrm{wt} \%$ at a $\mathrm{Na}_{2} \mathrm{O}$ loading of $22.0 \mathrm{wt} \%$. Glass ORPLD6, which can accommodate $1.2 \mathrm{wt} \% \mathrm{SO}_{3}$ at $24.0 \mathrm{wt} \% \mathrm{Na}_{2} \mathrm{O}$ loading can, therefore, be used to treat $\mathrm{LAW}$ AN-102 type streams with $\mathrm{SO}_{4} / \mathrm{Na}$ ratios of up to $2.5 \times 10^{-2}$.

ORPLF7: The glass formulation development for Region $F$ was based on the composition of LAW from Hanford tank AZ-102. The developed glass formulation, ORPLF7, has a target waste loading of $14.3 \mathrm{wt} \%$, with target $\mathrm{Na}_{2} \mathrm{O}$ and $\mathrm{SO}_{3}$ loadings of 12.0 and $1.5 \mathrm{wt} \%$, respectively. The waste loading for the previous ORP glass developed for this LAW stream, LAWB99 [6], had a 
target waste loading of 11.9 wt $\%$, with target $\mathrm{Na}_{2} \mathrm{O}$ and $\mathrm{SO}_{3}$ loadings of 10.0 and $1.5 \mathrm{wt} \%$, respectively. Another comparable glass is ORPLE12 [7], which was formulated for waste from LAW tank AZ-101, which had $\mathrm{Na}_{2} \mathrm{O}$ and $\mathrm{SO}_{3}$ loadings of 16.0 and $1.5 \mathrm{wt} \%$, respectively. It is interesting to note that all three glasses (LAWB99, ORPLE12 and ORPLF7) had a maximum $\mathrm{SO}_{3}$ loading of $1.5 \mathrm{wt} \%$, even though the $\mathrm{Na}_{2} \mathrm{O}$ concentrations varied from 10.0 to $16.0 \mathrm{wt} \%$. Glasses OPRLE12 and ORPLF7 were formulated with $\sim 0.5 \mathrm{wt} \% \mathrm{Cr}_{2} \mathrm{O}_{3}$ to minimize refractory corrosion, whereas LAWB99 contained only about $0.1 \mathrm{wt} \% \mathrm{Cr}_{2} \mathrm{O}_{3}$ entirely from the waste. These results suggest that $1.5 \mathrm{wt} \% \mathrm{SO}_{3}$ may be a practical limit for sulfur loading in LAW glasses, but there is a possibility that removal of the chromium additive may increase it slightly. It should be noted that LAWB99 was an early ORP glass and improvements in glass formulations since then have increased the capacity for sulfate loading in LAW glasses. In addition, since the K-3 corrosion issue in these glasses is cracking rather than material loss at the neck, glass formulations without $\mathrm{Cr}_{2} \mathrm{O}_{3}$ addition should be feasible. The waste loading of $14.3 \mathrm{wt} \%$ in ORPLF7 is substantially higher than that in the corresponding WTP LAW correlation glass, LAWE10H [52] of $6.2 \mathrm{wt} \%$, and the WTP LAW baseline glass, LAWB96 [13] of $5.5 \mathrm{wt} \%$. The nominal composition of LAW from tank AZ-102 has a $\mathrm{SO}_{4} / \mathrm{Na}$ molar ratio of $6.24 \times 10^{-2}$, which equates to an $\mathrm{SO}_{3}$ concentration of $1.93 \mathrm{wt} \%$ at a $\mathrm{Na}_{2} \mathrm{O}$ loading of $12.0 \mathrm{wt} \%$. Glass ORPLF7, which can accommodate $1.5 \mathrm{wt} \% \mathrm{SO}_{3}$ at $12.0 \mathrm{wt} \% \mathrm{Na}_{2} \mathrm{O}$ loading can, therefore, be used to treat LAW AZ-102 type streams with $\mathrm{SO}_{4} / \mathrm{Na}$ ratios of only up to $4.85 \times 10^{-2}$. In addition, blending LAW AZ-102 with other lower sulfur waste streams should allow ORP to reduce the overall amount of LAW glass produced at Hanford.

ORPLG9: The glass formulation development for Region $\mathrm{G}$ was based on the composition of LAW from Hanford tank AP-101. In addition to $\mathrm{Na}_{2} \mathrm{O}$ and $\mathrm{SO}_{3}$, this waste has a high concentration of $\mathrm{K}_{2} \mathrm{O}$. The developed glass formulation, ORPLG9, has a target waste loading of $29.1 \mathrm{wt} \%$, with target $\mathrm{Na}_{2} \mathrm{O}, \mathrm{K}_{2} \mathrm{O}$ and $\mathrm{SO}_{3}$ loadings of $21.0,5.8$ and $0.2 \mathrm{wt} \%$, respectively. The waste loading of $29.1 \mathrm{wt} \%$ in ORPLG9 is higher than that in the corresponding WTP LAW correlation glass, LAWE3 [52] of $25.4 \mathrm{wt} \%$, and the WTP LAW baseline glass, LAWA126 [13] of $24.5 \mathrm{wt} \%$. Due to the high alkali content, the properties of concern in glass formulation were VHT alteration rate and K-3 refractory corrosion. To determine processing characteristics of glasses at the limit of acceptable VHT alteration and K-3 corrosion, ORP selected ORPLG9 for DM10 melter tests. In this glass, in order to minimize K-3 corrosion, $\mathrm{Cr}_{2} \mathrm{O}_{3}$ was kept at a concentration of $0.59 \mathrm{wt} \%$. The measured $\mathrm{SO}_{3}$ solubility in the crucible glass was $0.48 \mathrm{wt} \%$ by batch saturation tests and $0.65 \mathrm{wt} \%$ by bubbling. However, during DM10 melter tests, a secondary sulfate layer was found even at the lowest sulfate level of $0.2 \mathrm{wt} \%$. The $\mathrm{Cr}_{2} \mathrm{O}_{3}$ content in the melter glass was $\sim 1.0 \mathrm{wt} \%$ or higher (see Figure 5.2 ). These observations may be the result of corrosion of the K-3 refractory by the ORPLG9 glass increasing its $\mathrm{Cr}_{2} \mathrm{O}_{3}$ content, and the interaction of chromate with sulfate causing sulfate phase formation. To understand this behavior further, bubbling tests for sulfate solubility were conducted on ORPLG9 glass samples with $0.59 \mathrm{wt} \%$ and $1.0 \mathrm{wt} \% \mathrm{Cr}_{2} \mathrm{O}_{3}$, the results of which are given in Figure 2.6. The sample with $0.59 \mathrm{wt} \% \mathrm{Cr}_{2} \mathrm{O}_{3}$ showed $\mathrm{SO}_{3}$ solubility of $0.65 \mathrm{wt} \%$, whereas the sample with $1.0 \mathrm{wt} \% \mathrm{Cr}_{2} \mathrm{O}_{3}$ showed $\mathrm{SO}_{3}$ solubility of $0.55 \mathrm{wt} \%$. More interestingly, the onset of a separate sulfate layer occurred at an $\mathrm{SO}_{3}$ concentration of $0.31 \mathrm{wt} \%$ in the sample with $0.59 \mathrm{wt} \% \mathrm{Cr}_{2} \mathrm{O}_{3}$, and at $0.17 \mathrm{wt} \% \mathrm{SO}_{3}$ in the sample with $1.0 \mathrm{wt} \% \mathrm{Cr}_{2} \mathrm{O}_{3}$. From these results, the increase in $\mathrm{Cr}_{2} \mathrm{O}_{3}$ concentration clearly increases the tendency for separate salt phase formation in the ORPLG9 
glass formulation and this likely was the cause for the low sulfate tolerance of the ORPLG9 melter feed. The strategy of adding $\mathrm{Cr}_{2} \mathrm{O}_{3}$ to improve K-3 refractory corrosion characteristics of high-alkali LAW glasses has clearly been successful in high-sodium, low-sulfur compositions. However, this strategy has disadvantages when the sulfur concentration is higher because any improvement in alkali loading may be offset by decrease in the sulfur loading. In addition, the presence of high $\mathrm{K}_{2} \mathrm{O}$ concentration also may be a contributing factor in the formation of secondary sulfate phase. The behavior of glass systems that simultaneously contain high concentrations of $\mathrm{Na}_{2} \mathrm{O}, \mathrm{K}_{2} \mathrm{O}, \mathrm{SO}_{3}$, and $\mathrm{Cr}_{2} \mathrm{O}_{3}$ is complex and would benefit from further investigation. Further work is needed to develop new glass formulations that allow higher sulfate loading at the same waste loading, or glass formulations with a lower waste loading to treat the LAW AP-101 type waste streams.

At the very high $\mathrm{Na}_{2} \mathrm{O}$ loadings (23 wt\% or higher), VHT response becomes especially challenging due to the rapid increase of VHT alteration rate with increasing alkali content, the increased variability in VHT response at high alkali content, and increased VHT alteration rates due to cracking in melter glasses. K-3 refractory corrosion also becomes an issue at very high alkali concentrations. At the low sodium end, a glass formulation, ORPLF7, with $12 \mathrm{wt} \% \mathrm{Na}_{2} \mathrm{O}$ that can accommodate $1.5 \mathrm{wt} \% \mathrm{SO}_{3}$ was identified. This was the same $\mathrm{SO}_{3}$ loading limit that was observed in LAWB99 with $10 \mathrm{wt} \% \mathrm{Na}_{2} \mathrm{O}$ and in ORPLE12 with $16 \mathrm{wt} \% \mathrm{Na}_{2} \mathrm{O}$ at a nominal melter operating temperature of $1150^{\circ} \mathrm{C}$. Achieving significantly higher $\mathrm{SO}_{3}$ loadings in borosilicate glasses would appear to be unlikely without changing the processing conditions or the processing and/or product quality constraints (e.g., it is a simple matter to achieve higher $\mathrm{SO}_{3}$ loadings by increasing the contents of $\mathrm{Li}, \mathrm{Ca}, \mathrm{V}$, etc., but such glasses do not meet VHT and refractory corrosion requirements). Thus, the glasses identified during the current and previous work [7] serve to define the likely limits of possible $\mathrm{Na}_{2} \mathrm{O}$ and $\mathrm{SO}_{3}$ loadings in Hanford LAW glasses that are compliant with the current product quality and processing requirements. Further work is needed to identify a high waste loading glass composition to treat LAW AP-101 type waste streams that contains high concentration of $\mathrm{K}_{2} \mathrm{O}$ in addition to $\mathrm{Na}_{2} \mathrm{O}$ and $\mathrm{SO}_{3}$. It should be noted, however, that these glasses were tested only at the crucible and DM10 melter scales. Additional testing at larger scales is required to confirm the results from smaller scale testing and the results of such testing may result in refinement of these limits. It should also be noted that because of the bounding nature of the formulations (they are deliberately close to the limits of the requirements), practically viable operating points would fall at somewhat lower waste loadings since nominal glass compositions selected for waste processing need to accommodate process variations without adverse effects on processing or product quality. In addition, the corrosion rate of Inconel in these new glass compositions has not been tested. While experience suggests that the adjustments made to the glass compositions to reduce VHT alteration rate and K-3 corrosion, along with the higher viscosity, will also maintain acceptable Inconel corrosion rates, this needs to be confirmed through testing.

\subsection{Implications for WTP}

VSL and EnergySolutions have previously developed and tested a number of LAW glass formulations for ORP [4-7] and WTP [12-15]. The formulations that were developed to support 
the WTP baseline, as distinct from those developed for ORP that were directed towards enhancements to that baseline, were tested at the crucible scale and at various melter scales, including the one-third scale LAW Pilot Melter at EnergySolutions. As a result of the considerable testing completed with the WTP baseline formulations, there is high confidence that they can be used to process LAW at Hanford with little additional testing. The recommended glass compositions for LAW processing were selected such that they can tolerate process variations without adverse effects on processing or product quality. Based on these well-tested formulations, VSL developed a LAW glass formulation correlation that is currently being used by the WTP [40]. Compositions produced by this correlation fall along the dotted lines in Figure 5.1. The WTP baseline formulations were developed to comply with the requirements of the Bechtel contract with ORP [54]. Although these formulations are fully compliant, extensive further optimization with respect to waste loading could not be performed due to the schedule constraints imposed by the LAW Pilot Melter testing program defined by the WTP Project. As a result, while this extensive basis set of formulations provides a solid underpinning of the WTP baseline, there is also potential for improvement of waste loadings. Exploiting this potential has been the subject of the present and previous work for ORP.

LAW testing for ORP at VSL and EnergySolutions was aimed at optimizing the glass formulations and processing parameters in order to minimize the volume of glass produced and to shorten the plant operating schedule. An important objective was to determine the likely limits of LAW loading across the full range of expected LAW compositions. Since the major waste loading limiting constituents in Hanford LAW are sodium and sulfur, glass formulation development and testing were focused on maximizing the incorporation of these components in the glass. Target and measured $\mathrm{Na}_{2} \mathrm{O}$ and $\mathrm{SO}_{3}$ concentrations in current and previous ORP LAW glasses for the same LAW streams are given in Table 5.1. A more extensive compilation of the target sodium, potassium, sulfur, and overall waste loading achieved for the four glass compositions from the present work and previous glasses developed for ORP and WTP are given in Table 5.2. An overview of the $\mathrm{Na}_{2} \mathrm{O}$ and $\mathrm{SO}_{3}$ loadings for the WTP and ORP glasses is given in Figure 5.1. As is evident from Figure 5.1 and Table 5.2, these glasses represent considerable increases in waste loadings over the WTP baseline and therefore considerable potential for reductions in cost and schedule. The principal objective of the present work was to assess the likely limits to the extent of this improvement for four LAW streams specified by ORP. Results from the present work combined with previous work for ORP [5-7], show the potential for a 58\% increase in average $\mathrm{Na}_{2} \mathrm{O}$ loading in Hanford LAW glasses from the WTP baseline of approximately $13 \mathrm{wt} \%$ to about $20.6 \mathrm{wt} \%$. This increase in waste loading has the potential to reduce the amount of LAW glass produced at Hanford by about 230,000 MT depending on the amount of process sodium additions. Importantly, these enhancements should be directly applicable to the planned supplemental treatment facility, which is now anticipated to be a second LAW plant. Furthermore, since the approach adopted in the present work was to span likely extremes in the expected LAW compositions, the results would remain relevant if various LAW tank wastes are blended, since blending generally has the effect of affording yet further improvements in waste loadings. 


\subsection{Recommendations for Future work}

The glass formulation developed in this work for LAW AP-101, ORPLG9, has a target waste loading of $29.1 \mathrm{wt} \%$, with target $\mathrm{Na}_{2} \mathrm{O}$ and $\mathrm{K}_{2} \mathrm{O}$ loadings of 21.0 and $5.8 \mathrm{wt} \%$, respectively. However, the $\mathrm{SO}_{3}$ loading in this glass is only about $0.2 \mathrm{wt} \%$. The low sulfur tolerance of this glass formulation was partly a result of $\mathrm{Cr}_{2} \mathrm{O}_{3}$ addition to reduce $\mathrm{K}-3$ refractory corrosion, but the chromium introduced via refractory corrosion may also have been a contributing factor. Further work is needed to better understand this behavior and to develop new glass formulations that allow higher sulfate loading at the same waste loading, or glass formulations with a lower waste loading to treat the LAW AP-101 type waste streams.

In much of the earlier high-alkali LAW glass development work, VHT response was the most constraining property. However, as the database for VHT response for high-alkali LAW glasses has grown and the performance of the VHT model in the composition region has improved [60], there have been corresponding increases in waste loadings for high-alkali glasses with acceptable VHT response. As a result, the present work indicates that K-3 refractory corrosion is now at least as constraining as VHT response for high-alkali LAW glasses. Consequently, more data on this important property and models for K-3 corrosion would be useful.

As discussed before, the high sulfate LAW formulations (LAWB99, ORPLE12 and ORPLF7) all show sulfate loading of $1.5 \mathrm{wt} \%$, even though the sodium loadings vary from 10 to $16 \mathrm{wt} \%$. Two of the three glasses (ORPLE12 and ORPLF7) contain $\mathrm{Cr}_{2} \mathrm{O}_{3}$ as an additive. It would be useful to determine whether sulfate loading in these glasses can be improved if $\mathrm{Cr}_{2} \mathrm{O}_{3}$ is not used as an additive.

It is also worth noting that bubbles and cracks that are present in melter glass samples can have significant effects on the measured VHT response, with the result that the measured effects may not necessarily be related solely to the glass composition. This appears to be particularly important for high-alkali glasses with VHT response near the WTP contract limit. More meaningful (or at least more consistent) results would likely be obtained with samples that are remelted to remove the bubbles.

The LAW correlation was developed for the WTP by VSL/EnergySolutions to determine the types and amounts of glass forming chemicals (GFCs) to be used at the WTP for LAW processing under the current WTP baseline. This was possible only after the completion of much more extensive testing than has been done for the new ORP glasses and after a set of nominal Sub-Envelope formulations were refined. The data collected so far for the ORP higher waste loading glasses is not yet sufficiently extensive to support a revised LAW correlation algorithm, but does serve to define what ranges of enhanced waste loadings should be possible. However, once sufficient data are collected, a new LAW formulation correlation similar to the one currently being used by the WTP needs to be developed to support the implementation of these 
higher waste loading glass compositions at the WTP in order to realize the cost and schedule reductions. The steps needed to collect the data to support a new LAW correlation include:

- Define GFC additives to be used at the WTP.

- Refine LAW glass formulations using the specified GFC additives.

- Develop new high waste loading glass formulation for AP-101 type LAW with high concentrations of $\mathrm{Na}, \mathrm{K}$ and $\mathrm{S}$.

- Refine waste loading in LAW glasses to accommodate the effect of halides.

- Specify waste loading limits for LAW formulations to accommodate process variations.

- Perform scale-up testing (DM100 and/or DM1200).

Since the process for producing such a revised correlation would closely parallel the one used successfully to develop the current WTP baseline, there is high confidence in the success of this approach. 


\section{SECTION 6.0 REFERENCES}

[1] LAW Pilot Melter Decommissioning and Testing, Letter Subcontract \#DE-AC2703RV14539.

[2] "Glass Formulation Testing to Increase Sulfate Incorporation," K.S. Matlack, M. Chaudhuri, H. Gan, I.S. Muller, W. Gong, and I.L. Pegg, Final Report, VSL-04R4960-1, Rev. 0, Vitreous State Laboratory, The Catholic University of America, Washington, DC, $2 / 28 / 05$.

[3] "Small Scale Melter Testing with LAW Simulants to Assess the Impact of Higher Temperature Melter Operations," K.S. Matlack, W. Gong, and I.L. Pegg, Final Report, VSL-04R4980-1, Rev. 0, Vitreous State Laboratory, The Catholic University of America, Washington, DC, 2/13/04.

[4] "Glass Formulation Testing to Increase Sulfate Volatilization from Melter," K.S. Matlack, W. Gong, and I.L. Pegg, Final Report, VSL-04R4970-1, Rev. 0, Vitreous State Laboratory, The Catholic University of America, Washington, DC, 2/24/05.

[5] "LAW Envelope C Glass Formulation Testing to Increase Waste Loading," K.S. Matlack, W. Gong, I.S. Muller, I. Joseph, and I.L. Pegg, Final Report, VSL-05R5900-1, Rev. 0, Vitreous State Laboratory, The Catholic University of America, Washington, DC, $1 / 27 / 06$.

[6] "LAW Envelope A and B Glass Formulation Testing to Increase Waste Loading," K.S. Matlack, H. Gan, I.S. Muller, I. Joseph, and I.L. Pegg, Final Report, VSL-06R6900-1, Rev. 0, Vitreous State Laboratory, The Catholic University of America, Washington, DC, $3 / 23 / 06$.

[7] "Enhanced LAW Glass Formulation Testing," K.S. Matlack, I. Joseph, W. Gong, I.S. Muller, and I.L. Pegg, Final Report, VSL-07R1130-1, Rev. 0, Vitreous State Laboratory, The Catholic University of America, Washington, DC, 10/05/07.

[8] "Summary of Preliminary Results on Enhanced Sulfate Incorporation During Vitrification of LAW Feeds", I.L. Pegg, H. Gan, I.S. Muller, D.A. McKeown, and K.S. Matlack, VSL-00R3630-1, Vitreous State Laboratory, The Catholic University of America, Washington, DC, 4/5/00.

[9] "Sulfur Incorporation in Waste Glass Melts of Various Compositions," W.K. Kot, H. Gan, and I.L. Pegg, Ceramic Transactions, Vol. 107, pp. 441, Eds. G.T. Chandler and X. Feng, American Ceramic Society, 2000. 
[10] "Melter Tests with LAW Envelope B Simulants to Support Enhanced Sulfate Incorporation," K.S. Matlack, S.P. Morgan, and I.L. Pegg, Final Report, VSL-00R35011, Rev. 0, Vitreous State Laboratory, The Catholic University of America, Washington, D.C., $11 / 27 / 00$.

[11] "Melter Tests with LAW Envelope A and C Simulants to Support Enhanced Sulfate Incorporation," K.S. Matlack, S.P. Morgan, and I.L. Pegg, Final Report, VSL-01R35012, Rev. 0, Vitreous State Laboratory, The Catholic University of America, Washington, D.C., $1 / 26 / 01$.

[12] "Glass Formulation and Testing with TWRS LAW Simulants," I.S. Muller and I.L. Pegg, Final Report, Vitreous State Laboratory, The Catholic University of America, Washington, DC, 1/16/98.

[13] "Glass Formulation And Testing With RPP-WTP LAW Simulants," I.S. Muller, A.C. Buechele, and I.L. Pegg, Final Report, VSL-01R3560-2, Vitreous State Laboratory, The Catholic University of America, Washington, DC, 2/23/01.

[14] "Baseline LAW Glass Formulation Testing," I.S. Muller and I.L. Pegg, Final Report, VSL-03R3460-1, Rev. 0, Vitreous State Laboratory, The Catholic University of America, Washington, DC, 8/8/03.

[15] “Glass Formulations to Support Melter Testing”, I.S. Muller and I.L. Pegg, Final Report, VSL-03R3460-2, Rev. 0, Vitreous State Laboratory, The Catholic University of America, Washington, DC, 2/6/04.

[16] "Preparation and Testing of LAW Matrix Glasses to Support WTP Property-Composition Model Development," E. Rielley, I.S. Muller and I.L. Pegg, Final Report, VSL-04R44801, Rev. 0, Vitreous State Laboratory, The Catholic University of America, Washington, DC, $4 / 21 / 04$

[17] "ILAW PCT, VHT, Viscosity, and Electrical Conductivity Model Development," G.F. Piepel, S.K. Cooley, I.S. Muller, H. Gan, I. Joseph and I.L. Pegg, Final Report, VSL07R1230-1, Rev. 0, Vitreous State Laboratory, The Catholic University of America, Washington, DC, 6/28/07

[18] "Compositional Variation Tests on DuraMelter 100 with LAW Sub-Envelope A1 Feed (LAWA44 Glass) in Support of the LAW Pilot Melter," K.S. Matlack, W. Gong, and I.L. Pegg, Final Report, VSL-02R62N0-4, Rev. 0, Vitreous State Laboratory, The Catholic University of America, Washington, D.C., 6/18/02.

[19] "Compositional Variation Tests on DuraMelter 100 with LAW Sub-Envelope A2 Feed (LAWA88) Glass in Support of the LAW Pilot Melter," K. S. Matlack, W. Gong and I.L. Pegg, Final Report, VSL-02R62N0-3, Rev. 0, Vitreous State Laboratory, The Catholic University of America, Washington, D.C., 11/1/02. 
[20] "Compositional Variation Tests on DuraMelter 100 with LAW Sub-Envelope A3 Feed in Support of the LAW Pilot Melter," K.S. Matlack, W. Gong, and I.L. Pegg, Final Report, VSL-01R62N0-1, Rev. 1, Vitreous State Laboratory, The Catholic University of America, Washington, D.C., 7/15/02.

[21] "Compositional Variation Tests on DuraMelter 100 with LAW Sub-Envelope B1 Feed in Support of the LAW Pilot Melter," K.S. Matlack, W. Gong, and I.L. Pegg, Final Report, VSL-02R62N0-5, Rev. 0, Vitreous State Laboratory, The Catholic University of America, Washington, D.C., 5/8/03.

[22] "Compositional Variation Tests on DuraMelter 100 with LAW Sub-Envelope B2 Feed in Support of the LAW Pilot Melter," K.S. Matlack and I.L. Pegg, Final Report, VSL03R3410-2, Rev. 0, The Catholic University of America, Vitreous State Laboratory, Washington, D.C., 10/20/03.

[23] "Compositional Variation Tests on DuraMelter 100 with LAW Sub-Envelope C1 Feed (LAWC22 Glass) in Support of the LAW Pilot Melter," K.S. Matlack, W. Gong, and I.L. Pegg, Final Report, VSL-02R62N0-2, Rev. 1, Vitreous State Laboratory, The Catholic University of America, Washington, D.C., 9/23/02.

[24] "Compositional Variation Tests on DuraMelter 100 with LAW Sub-Envelope C2 Feed in Support of the LAW Pilot Melter," K.S. Matlack, W. Gong, R.A. Callow and I.L. Pegg, Final Report, VSL-04R4410-1, Rev. 0, Vitreous State Laboratory, The Catholic University of America, Washington, DC, 6/17/04.

[25] "DuraMelter 100 Sub-Envelope Changeover Testing Using LAW Sub-Envelope A1 and C1 Feeds in Support of the LAW Pilot Melter," K.S. Matlack, W. Gong, and I.L. Pegg, Final Report, VSL-02R62N0-6, Rev. 0, Vitreous State Laboratory, The Catholic University of America, Washington, D.C., 9/9/03.

[26] "DuraMelter 100 Sub-Envelope Changeover Testing Using LAW Sub-Envelope A2 and B1 Feeds in Support of the LAW Pilot Melter," K.S. Matlack, W. Gong, and I.L. Pegg, Final Report, VSL-03R3410-1, Rev. 0, Vitreous State Laboratory, The Catholic University of America, Washington, D.C., 8/22/03.

[27] "DuraMelter 100 Sub-Envelope Changeover Testing Using LAW Sub-Envelope A3 and C2 Feeds in Support of the LAW Pilot Melter," K.S. Matlack, W. Gong, and I.L. Pegg, Final Report, VSL-03R3410-3, Rev. 0, Vitreous State Laboratory, The Catholic University of America, Washington, D.C., 10/17/03.

[28] “RPP-WTP Pilot Melter Envelope B Throughput Test Results Report," TRR-PLT-57, Duratek, Inc., Columbia, MD, 10/13/00. 
[29] "RPP-WTP Pilot Melter Envelope A and C Throughput Test Results Report," TRR-PLT54, Duratek, Inc., Columbia, MD, 10/13/00.

[30] "RPP-WTP Pilot Melter Sub-Envelope A1 Variation Test Results Report," TRR-PLT071, Rev. 0, Duratek, Inc., Columbia, MD, 4/28/03.

[31] "RPP-WTP Pilot Melter Sub-Envelope C1-A1 Changeover Test Results Report," TRRPLT-035, Rev. 0, Duratek, Inc., Columbia, MD, 9/29/03.

[32] "RPP-WTP Pilot Melter Sub-Envelope A2 Variation Test Results Report," TRR-PLT070, Rev. 0, Duratek, Inc., Columbia, MD, 10/4/02.

[33] "RPP-WTP Pilot Melter Sub-Envelope A2-B1 Changeover Test Results Report," TRRPLT-078, Rev. 0, Duratek, Inc., Columbia, MD, 11/3/03.

[34] "RPP-WTP Pilot Melter Sub-Envelope A3 Variation Test Results Report," TRR-PLT060, Rev. 2, Duratek, Inc., Columbia, MD, 11/19/02.

[35] "RPP-WTP Pilot Melter Sub-Envelope C2-A3 Changeover Test Results Report," TRRPLT-079, Rev. 0, Duratek, Inc., Columbia, MD, 11/11/03.

[36] "RPP-WTP Pilot Melter Sub-Envelope B1 Variation Test Results Report," TRR-PLT074, Rev. 0, Duratek, Inc., Columbia, MD, 8/26/03.

[37] "RPP-WTP Pilot Melter Sub-Envelope B2 Variation Test Results Report," TRR-PLT073, Rev. 0, Duratek, Inc., Columbia, MD, 10/27/03.

[38] "RPP-WTP Pilot Melter Sub-Envelope C1 Variation Test Results Report," TRR-PLT069, Rev. 2, Duratek, Inc., Columbia, MD, 2/6/03.

[39] "RPP-WTP Pilot Melter Sub-Envelope C2 Variation Test Results Report," TRR-PLT072, Rev. 1, Duratek, Inc., Columbia, MD, 3/12/03.

[40] "Proposed Approach for Development of LAW Glass Formulation Correlation," I.S. Muller, G. Diener, I. Joseph, and I.L. Pegg, Final Report, VSL-04L4460-1, Rev. 2, Vitreous State Laboratory, The Catholic University of America, Washington, DC, 10/29/04.

[41] "LAW Glass Formulation Development and Testing," K.S. Matlack, I.S. Muller, I. Joseph, and I.L. Pegg, Test Plan, VSL-08T1510-1, Rev. 0, Vitreous State Laboratory, The Catholic University of America, Washington, DC, 6/06/08.

[42] "Test and Evaluate High Level Waste (HLW) Vitrification System Improvements," Contract \# DE-AC27-07RV14884 dated 9/28/07 and Amendment A001 dated 4/23/08. 
[43] "DuraMelter 100 Tests to Support LAW Glass Formulation Correlation Development," K.S. Matlack, I.S. Muller, W. Gong, and I.L. Pegg, Final Report, VSL-06R6480-1, Rev. 0, Vitreous State Laboratory, The Catholic University of America, Washington, DC, 2/27/06.

[44] "Crystal Settling, Redox, and High Temperature Properties of ORP HLW and LAW Glasses,” H. Gan, I. S. Muller, D. A. McKeown, M. Chaudhuri, Z. Feng, C. Viragh, C. Wang, R.Cecil, W.Zhao, W. K. Kot, I. Joseph, and I. L. Pegg, Final Report, VSL09R1510-1, Rev. A, Vitreous State Laboratory, The Catholic University of America, Washington, DC, 3/31/09.

[45] "Quality Assurance Project Plan for ORP Support Activities Conducted by VSL," Vitreous State Laboratory, VSL-QAPP-ORP, Rev. 0, Vitreous State Laboratory, The Catholic University of America, Washington, DC, 6/24/08.

[46] "Master List of Controlled VSL Manuals and Standard Operating Procedures in Use," QA-MLCP, Rev. 36, Vitreous State Laboratory, The Catholic University of America, Washington, DC, 2/19/09.

[47] "LAW Pilot Melter and DM-100 Sub-Envelope Changeover Testing," E.V. Morrey, WTP Test Specification, 24590-LAW-TSP-RT-02-012, Rev. 0.

[48] "Tank Farm Contractor Operation and Utilization Plan," R.A. Kirkbride, et al., CH2M Hill Hanford Group Inc., Richland, WA, HNF-SD-SP-012, Rev. 3, 10/2/01.

[49] “Basis of Design,” BNFL report, DB-W375-EG00001, Rev. 0, November 23, 1998.

[50] "Physical and Rheological Properties of Waste Simulants and Melter Feeds for RPPWTP LAW Vitrification," I.S. Muller, H. Gan, and I.L. Pegg, Final Report, VSL00R3520-1, Rev. 0, Vitreous State Laboratory, The Catholic University of America, Washington, DC, 1/16/01.

[51] “Characterization of Simulated WTP LAW Melter Feeds," H. Zhao, I.S. Muller, and I.L. Pegg, Final Report, VSL-04R4500-1, Rev. 0, Vitreous State Laboratory, The Catholic University of America, Washington, DC, 5/26/04.

[52] "Small Scale Melter Testing of LAW Salt Phase Separation," K.S. Matlack, I.S. Muller, W. Gong, and I.L. Pegg, VSL-07R7480-1, Rev. 0, Vitreous State Laboratory, The Catholic University of America, Washington, DC, 8/20/07.

[53] "Engineering Specification for Low Activity Waste Melters," K. Clark, 24590-LAW3PS-AE00-T0001, River Protection Project - Waste Treatment Plant, Richland, WA, 2003 
[54] U.S. Department of Energy, Office of River Protection, "Design, Construction, and Commissioning of the Hanford Tank Waste Treatment and Immobilization Plant," Contract Number: DE-AC27-01RV14136, 2001; and subsequent amendments

[55] "Composition Effects on the Vapor Hydration of Waste Glasses," A.C. Buechele, F. Lofaj, I.S. Muller, C.T. Mooers, and I.L. Pegg, Ceramic Transactions, Vol. 155, p. 289, (2004).

[56] "Vapor Hydration Testing of Tin-Containing Glasses", A. Buechele, C. T. Mooers, I.S. Muller, H. Gan and I.L. Pegg, 106th Annual Meeting of The American Ceramic Society, April 4, Indianapolis, 2004.

[57] "Tin as an Additive to Improve the VHT performance of High-Alkali Waste Glasses", A.C. Buechele, C.T. Mooers, I.S. Muller, H. Gan, and I.L. Pegg, Materials Science and Technologies 2006, Cincinnati, OH, Oct. 15-18, 2006.

[58] "Earliest Stages of Crystal Growth in a Silicate Glass Containing Titanium and Zirconium as Nucleating Elements" Ramos A., Gandais M. Journal of Crystal Growth, vol. 100, pp. 471-480 (1990).

[59] “Corrosion of K-3 Refractory and Metal Alloys in RPP-WTP LAW Glasses” H. Gan, X. Lu, I. Vidensky, C. Paul and I.L. Pegg, VSL-01R3540-1, Rev. 1, Vitreous State Laboratory, The Catholic University of America, Washington, DC, 03/16/01.

[60] "LAW Glass Testing and VHT Model Assessment" I.S. Muller, I. Joseph, F. PerezCardenas and I.L. Pegg, VSL-08R1410-1, Rev. 0, Vitreous State Laboratory, The Catholic University of America, Washington, DC, 09/18/08.

[61] "Integrated Off-Gas System Tests on the DM1200 Melter with RPP-WTP LAW SubEnvelope A1 Simulants," K.S. Matlack, W. Gong, T. Bardakci, N. D’Angelo, and I.L. Pegg, Final Report, VSL-02R8800-2, Rev. 0, Vitreous State Laboratory, The Catholic University of America, Washington, DC, 9/03/02.

[62] "Integrated Off-Gas System Tests on the DM1200 Melter with RPP-WTP LAW SubEnvelope C1 Simulants,” K.S. Matlack, W. Gong, T. Bardakci, D’Angelo, and I.L. Pegg, Final Report, VSL-02R8800-1, Rev. 0, Vitreous State Laboratory, The Catholic University of America, Washington, DC, 7/25/02.

[63] "Regulatory Off-Gas Emissions Testing on the DM1200 Melter System Using HLW and LAW Simulants," K.S. Matlack, W. Gong, T. Bardakci, N. D’Angelo, M. Brandys, W. Kot, and I.L. Pegg, Final Report, VSL-05R5830-1, Rev. 0, Vitreous State Laboratory, The Catholic University of America, Washington, DC, 10/31/05 
[64] "Review of Properties of Simulated Feeds Used for Melter Testing," K.S. Matlack, W. Gong, and I.L. Pegg, Final Report, VSL-06R6410-1, Rev. 0, Vitreous State Laboratory, The Catholic University of America, Washington, DC, Washington, D.C., 8/16/06.

[65] "Technetium/Cesium Volatility in DM100 Tests Using HLW AZ-102 and LAW SubEnvelope A1 Simulants," Final Report, K.S. Matlack, W.K. Kot, and I.L. Pegg, VSL04R4710-1, Rev. 0, Vitreous State Laboratory, The Catholic University of America, Washington, D.C., 9/28/04.

[66] "Round Robin Testing of a Reference Glass for Low-Activity Waste Forms," W.L. Ebert and S.F. Wolf, Department of Energy report ANL-99/22, Argonne National Laboratory, Argonne, IL, 1999.

[67] "High Level Waste Vitrification System Improvements," K.S. Matlack, H. Gan, W. Gong, I.L. Pegg, C.C. Chapman, and I. Joseph, VSL-07R1010-1, Rev. 0, Vitreous State Laboratory, The Catholic University of America, Washington, DC, 04/16/07. 
Table 1.1. Waste Compositions and Corresponding Target Concentrations in Glass.

\begin{tabular}{|c|c|c|c|}
\hline $\begin{array}{c}\text { Region } \\
\text { Designation }\end{array}$ & $\begin{array}{c}\text { Tank Waste/ } \\
\text { Sub-Envelope } \\
\text { Identification }\end{array}$ & $\begin{array}{c}\text { Based on Correlation } \\
\text { Formulation }\end{array}$ & $\begin{array}{c}\text { Target Minimum } \\
\text { Waste Loading, wt\% }\end{array}$ \\
\hline A & $\begin{array}{c}\text { AN-105/ } \\
\text { Sub-Envelope A1 }\end{array}$ & LAWE4H & 27.18 \\
\hline D & $\begin{array}{c}\text { AN-102/ } \\
\text { Sub-Envelope C2 }\end{array}$ & LAWE7H & 16.22 \\
\hline F & $\begin{array}{c}\text { AZ-101/ } \\
\text { Sub-Envelope B2 } \\
\text { AP-101/ } \\
\text { Sub-Envelope A2 }\end{array}$ & LAWE10H & 6.20 \\
\hline L & \multicolumn{2}{|c}{ LAWE3 } & 25.41 \\
\hline
\end{tabular}


Table 2.1. LAW Sub-Envelope A1 for AN-105 Waste Simulant Recipe at Nominal 8 Molar Sodium.

\begin{tabular}{|c|c|c|c|c|c|c|c|c|c|}
\hline \multirow{4}{*}{\begin{tabular}{|c}
$\begin{array}{c}\text { Envelope } \\
\text { Constituents }\end{array}$ \\
- \\
$\mathrm{Al}$
\end{tabular}} & \multicolumn{2}{|c|}{$\begin{array}{l}\text { Simulant for AN-105 } \\
\text { including pretreatment }\end{array}$} & \multirow{2}{*}{$\begin{array}{c}\text { Glass } \\
\text { Oxides } \\
\text { Loading }\end{array}$} & \multirow[t]{2}{*}{$\begin{array}{c}\text { AN-105 } \\
\text { Simulant as } \\
\text { Oxides (wt\%) }\end{array}$} & $\begin{array}{l}\text { Source in } \\
\text { Simulant }\end{array}$ & $\begin{array}{l}\text { Order for } \\
\text { Addition }\end{array}$ & $\begin{array}{l}\text { Formula } \\
\text { Weight }\end{array}$ & Assay* & $\begin{array}{c}\text { Target } \\
\text { Weight (g) }\end{array}$ \\
\hline & $\mathrm{mg} / \mathrm{L}$ & M & & & \multicolumn{5}{|c|}{ In $274 \mathrm{ml}$ water add following compounds in the order listed below } \\
\hline & \multirow{2}{*}{30554} & \multirow{2}{*}{1.132} & \multirow{2}{*}{$\mathrm{Al}_{2} \mathrm{O}_{3}$} & \multirow{2}{*}{17.99} & $\mathrm{Al}\left(\mathrm{NO}_{3}\right)_{3} .9 \mathrm{H}_{2} \mathrm{O}, 60 \%$ sol. & 1 & 375.14 & 0.61 & 422.01 \\
\hline & & & & & $\mathrm{Al}(\mathrm{OH})_{3}$ & 7 & 78.00 & 1.00 & 35.22 \\
\hline $\mathrm{B}$ & 79 & 0.007 & $\mathrm{~B}_{2} \mathrm{O}_{3}$ & 0.08 & $\mathrm{H}_{3} \mathrm{BO}_{3}$ & 2 & 61.83 & 0.99 & 0.45 \\
\hline $\mathrm{Cr}$ & 149 & 0.003 & $\mathrm{Cr}_{2} \mathrm{O}_{3}$ & 0.07 & $\mathrm{Na}_{2} \mathrm{CrO}_{4} \cdot 4 \mathrm{H}_{2} \mathrm{O}$ & 6 & 234.04 & 0.99 & 0.68 \\
\hline $\mathrm{Na}$ & 183920 & 8.000 & $\mathrm{Na}_{2} \mathrm{O}$ & 77.25 & $\mathrm{NaOH}, 50 \%$ sol. $\mathrm{d}=1.53$ & 4 & 40.00 & 0.50 & 463.20 \\
\hline $\mathrm{Si}$ & 157 & 0.006 & $\mathrm{SiO}_{2}$ & 0.10 & $\mathrm{SiO}_{2}$ & 3 & 60.09 & 0.99 & 0.34 \\
\hline $\mathrm{Cl}$ & 6996 & 0.065 & $\mathrm{Cl}$ & 2.18 & $\mathrm{NaCl}$ & 8 & 58.45 & 0.99 & 11.65 \\
\hline $\mathrm{F}$ & 35 & 0.048 & $\mathrm{~F}$ & 0.01 & $\mathrm{NaF}$ & 9 & 42.00 & 0.99 & 0.08 \\
\hline $\mathrm{SO}_{4}\left(\right.$ Nominal $^{\$}$ & 2274 & 0.024 & $\mathrm{SO}_{3}$ & 0.59 & $\mathrm{Na}_{2} \mathrm{SO}_{4}$ & 10 & 142.06 & 0.99 & $3.40^{\$}$ \\
\hline $\mathrm{NO}_{2}$ & 85428 & 1.857 & - & - & $\mathrm{NaNO}_{2}$ & 14 & 69.00 & 0.97 & 128.79 \\
\hline $\mathrm{NO}_{3}$ & 126988 & 2.048 & - & - & $\mathrm{NaNO}_{3}$ & - & 84.99 & 0.99 & 0.00 \\
\hline Acetate & 2251 & 0.038 & - & - & Sodium Acetate (C2) & 11 & 136.08 & 0.99 & 5.24 \\
\hline Formate & 2135 & 0.047 & - & - & Sodium Formate (C1) & 12 & 68.01 & 0.99 & 3.26 \\
\hline Glycolate & 1936 & 0.025 & - & - & Glycolic Acid (C2) & 13 & 76.05 & 0.71 & 2.73 \\
\hline- & - & - & SUM & 100.00 & Total simulant wt. & & & & 1358.73 \\
\hline
\end{tabular}

"-" Empty data field.

* Assay refers to the purity of the raw material as specified by the vendor.

${ }^{\$} \mathrm{SO}_{3}$ content varied during each run, as given in Table 2.10b. The value given here corresponds to the nominal. 
Table 2.2. Target and Analyzed Compositions (wt\%) of Eight ORPLA Crucible Glasses.

\begin{tabular}{|c|c|c|c|c|c|c|c|c|}
\hline GLASS & \multicolumn{2}{|c|}{ ORPLA18 } & \multicolumn{2}{c|}{ ORPLA19 } & \multicolumn{2}{c|}{ ORPLA20 } & \multicolumn{2}{c|}{ ORPLA21 } \\
\hline Oxides & Target & Analyzed & Target & Analyzed & Target & Analyzed & Target & Analyzed $^{*}$ \\
\hline $\mathrm{Al}_{2} \mathrm{O}_{3}$ & 9.70 & 9.41 & 9.70 & 9.22 & 6.70 & 6.40 & 6.91 & 6.75 \\
\hline $\mathrm{B}_{2} \mathrm{O}_{3}$ & 8.80 & 9.23 & 8.80 & 9.18 & 8.80 & 9.34 & 8.64 & 8.76 \\
\hline $\mathrm{CaO}$ & 3.34 & 3.50 & 3.34 & 3.50 & 3.34 & 3.54 & 3.28 & 3.48 \\
\hline $\mathrm{Cr}_{2} \mathrm{O}_{3}$ & 0.50 & 0.64 & 0.50 & 0.68 & 0.50 & 0.67 & 0.50 & 0.63 \\
\hline $\mathrm{Fe}_{2} \mathrm{O}_{3}$ & 0.30 & 0.32 & 0.30 & 0.34 & 0.30 & 0.33 & 0.29 & 0.32 \\
\hline $\mathrm{K}_{2} \mathrm{O}$ & 0.54 & 0.53 & 0.54 & 0.52 & 0.54 & 0.52 & 0.56 & 0.55 \\
\hline $\mathrm{MgO}$ & 0.93 & 0.83 & 0.93 & 0.83 & 0.93 & 0.81 & 0.91 & 0.94 \\
\hline $\mathrm{Na}_{2} \mathrm{O}$ & 24.00 & 23.58 & 24.00 & 23.35 & 24.00 & 23.36 & 25.00 & 24.33 \\
\hline $\mathrm{SiO}_{2}$ & 39.52 & 39.35 & 39.52 & 39.13 & 42.51 & 42.00 & 41.72 & 41.85 \\
\hline $\mathrm{SnO}_{2}$ & 2.76 & 3.12 & 4.83 & 5.64 & 2.76 & 3.43 & 2.71 & 2.91 \\
\hline $\mathrm{ZnO}^{2}$ & 2.76 & 2.84 & 2.76 & 2.92 & 2.76 & 2.95 & 2.71 & 2.83 \\
\hline $\mathrm{ZrO}_{2}$ & 6.00 & 5.80 & 3.93 & 3.94 & 6.00 & 6.05 & 5.88 & 5.62 \\
\hline $\mathrm{Cl}$ & 0.68 & 0.72 & 0.68 & 0.61 & 0.68 & 0.60 & 0.71 & 0.62 \\
\hline $\mathrm{SO}_{3}$ & 0.18 & 0.17 & 0.18 & 0.17 & 0.18 & 0.16 & 0.19 & 0.18 \\
\hline $\mathrm{SUM}^{*}$ & 100.0 & 100.0 & 100.0 & 100.0 & 100.0 & 100.2 & 100.0 & 99.8 \\
\hline
\end{tabular}

* Analyzed by X-ray fluorescence except for boron which was measured by DCP 
Table 2.2. Target and Analyzed Compositions (wt\%) of Eight ORPLA Crucible Glasses (continued).

\begin{tabular}{|c|c|c|c|c|c|c|c|c|}
\hline GLASS & \multicolumn{2}{|c|}{ ORPLA22 } & \multicolumn{2}{c|}{ ORPLA23 } & \multicolumn{2}{c|}{ ORPLA24 } & \multicolumn{2}{c|}{ ORPLA25 } \\
\hline Oxides & Target & Analyzed & Target & Analyzed & Target & Analyzed & Target & Analyzed $^{*}$ \\
\hline $\mathrm{Al}_{2} \mathrm{O}_{3}$ & 9.46 & 9.24 & 9.46 & 9.16 & 9.34 & 9.07 & 9.17 & 8.81 \\
\hline $\mathrm{B}_{2} \mathrm{O}_{3}$ & 8.80 & 9.30 & 8.80 & 9.49 & 8.55 & 9.14 & 8.39 & 8.13 \\
\hline $\mathrm{CaO}$ & 3.55 & 3.64 & 3.55 & 3.63 & 3.52 & 3.64 & 3.45 & 3.60 \\
\hline $\mathrm{Cr}_{2} \mathrm{O}_{3}$ & 0.50 & 0.63 & 0.50 & 0.63 & 0.50 & 0.61 & 0.49 & 0.61 \\
\hline $\mathrm{Fe}_{2} \mathrm{O}_{3}$ & 0.00 & 0.01 & 0.00 & 0.00 & 0.00 & 0.00 & 0.00 & 0.00 \\
\hline $\mathrm{K}_{2} \mathrm{O}$ & 0.54 & 0.51 & 0.54 & 0.51 & 0.56 & 0.53 & 0.58 & 0.51 \\
\hline $\mathrm{MgO}$ & 0.00 & 0.00 & 0.00 & 0.00 & 0.00 & 0.00 & 0.00 & 0.00 \\
\hline $\mathrm{Na}_{2} \mathrm{O}$ & 24.00 & 23.63 & 24.00 & 23.87 & 25.00 & 24.79 & 26.00 & 26.10 \\
\hline $\mathrm{SiO}_{2}$ & 40.29 & 40.72 & 40.29 & 39.79 & 39.70 & 39.58 & 39.10 & 38.85 \\
\hline $\mathrm{SnO}_{2}$ & 3.00 & 3.19 & 5.00 & 5.65 & 3.00 & 3.28 & 3.00 & 3.30 \\
\hline $\mathrm{ZnO}^{2}$ & 3.00 & 3.01 & 3.00 & 3.05 & 2.94 & 2.98 & 2.89 & 2.93 \\
\hline $\mathrm{ZrO}_{2}$ & 6.00 & 5.44 & 4.00 & 3.73 & 6.00 & 5.64 & 6.00 & 5.66 \\
\hline $\mathrm{Cl}$ & 0.68 & 0.62 & 0.68 & 0.64 & 0.71 & 0.74 & 0.73 & 0.72 \\
\hline $\mathrm{SO}_{3}$ & 0.18 & 0.17 & 0.18 & 0.17 & 0.19 & 0.17 & 0.20 & 0.18 \\
\hline $\mathrm{SUM}_{*}$ & 100.0 & 100.1 & 100.0 & 100.3 & 100.0 & 100.2 & 100.0 & 99.4 \\
\hline
\end{tabular}

* Analyzed by X-ray fluorescence except for boron which was measured by DCP 
Table 2.3. Descriptions of Eight As-Melted and Heat Treated ORPLA Crucible Glasses.

\begin{tabular}{|c|c|c|}
\hline Glass ID & As-melted glass & $\begin{array}{c}\text { Glass remelted at } 1200^{\circ} \mathrm{C} \text { for } 1 \text { hour, heat treated for } 20 \text { hours at } 950^{\circ} \mathrm{C} \text {, and } \\
\text { quenched. }\end{array}$ \\
\hline ORPLA18 & Clear glass. $<<0.1$ vol\% of small Cr oxide crystals & Clear glass. $<0.1$ vol\% Na-Zr silicate + Sn crystal + many submicron Au-Pt crystals \\
\hline ORPLA19 & Clear glass. $<<0.1$ vol\% of small Cr oxide crystals & Clear glass. $<<0.1$ vol\% Sn Oxide crystal + many submicron Au-Pt crystals \\
\hline ORPLA20 & Clear glass. $<<0.1$ vol\% of small Cr oxide crystals & Clear glass, showing many acicular submicron Au-Pt crystals \\
\hline ORPLA21 & Clear glass. $<<0.1$ vol\% of small Cr oxide crystals & $\sim 0.8$ vol\% large Na-Zr silicate + Sn crystal \\
\hline ORPLA22 & Clear glass. $<<0.1$ vol\% of small Cr oxide crystals & $\sim 0.2$ vol\% large $\mathrm{Na}-\mathrm{Zr}$ silicate + Sn crystal \\
\hline ORPLA23 & Clear glass. $<<0.1$ vol\% of small Cr oxide crystals & Mostly clear glass. $\sim 0.1$ vol\% large Na-Zr silicate + Sn crystal \\
\hline ORPLA24 & Clear glass $<0.1 \%$ tiny Cr oxide crystals & Mostly clear glass. $\sim 0.1$ vol\% Na-Zr silicate + Sn crystal \\
\hline ORPLA25 & Clear glass $<0.1 \%$ tiny Cr oxide crystals & Mostly clear glass. $\sim 0.1$ vol\% Na-Zr silicate + Sn crystal \\
\hline
\end{tabular}


Table 2.4. Measured Sulfate Solubility Limits in Eight ORPLA Glasses.

\begin{tabular}{|c|c|c|}
\hline \multirow{3}{*}{ Sample ID } & \multicolumn{2}{|c|}{$\mathrm{SO}_{3}$ Content (wt\%) } \\
\hline & \multicolumn{2}{|c|}{ Batch Saturation } \\
\hline & As-Melted & After Acid Wash \\
\hline ORPLA18S4 & 0.31 & 0.30 \\
\hline ORPLA19S4 & 0.33 & 0.32 \\
\hline ORPLA20S4 & 0.38 & 0.37 \\
\hline ORPLA21S4 & 0.40 & 0.37 \\
\hline ORPLA22S4 & 0.34 & 0.33 \\
\hline ORPLA23S4 & 0.35 & 0.36 \\
\hline ORPLA24S4 & 0.36 & 0.35 \\
\hline ORPLA25S4 & 0.42 & 0.41 \\
\hline
\end{tabular}


Table 2.5. Results of 7-day PCT (at $90^{\circ} \mathrm{C}$ ) and VHT (at $200^{\circ} \mathrm{C}$ for 24 Days) for Eight ORPLA Crucible Glasses.

\begin{tabular}{|c|c|c|c|c|c|c|c|c|}
\hline Glass ID & ORPLA18 & ORPLA19 & ORPLA20 & ORPLA21 & ORPLA22 & ORPLA23 & ORPLA24 & ORPLA25 \\
\hline \multicolumn{9}{|c|}{ 7-Day PCT, Stainless Steel Vessel; S/V=2000m ${ }^{-1} \quad(p p m)$} \\
\hline $\mathrm{B}$ & 30.34 & 36.03 & 39.61 & 51.06 & 28.77 & 24.86 & 32.10 & 44.00 \\
\hline $\mathrm{Na}$ & 206.20 & 247.50 & 261.40 & 350.60 & 224.70 & 210.40 & 274.30 & 375.80 \\
\hline $\mathrm{Si}$ & 67.09 & 81.98 & 91.43 & 106.50 & 66.71 & 70.49 & 72.94 & 85.02 \\
\hline \multicolumn{9}{|c|}{ Normalized Concentrations (g/L) } \\
\hline $\mathrm{B}$ & 1.11 & 1.32 & 1.45 & 1.90 & 1.05 & 0.91 & 1.21 & 1.69 \\
\hline $\mathrm{Na}$ & 1.16 & 1.39 & 1.47 & 1.89 & 1.26 & 1.18 & 1.48 & 1.95 \\
\hline $\mathrm{Si}$ & 0.36 & 0.44 & 0.46 & 0.55 & 0.35 & 0.37 & 0.39 & 0.47 \\
\hline $\mathrm{pH}$ & 11.67 & 11.75 & 11.77 & 11.95 & 11.74 & 11.67 & 11.7 & 11.93 \\
\hline \multicolumn{9}{|c|}{ 7-Day PCT Normalized Mass Loss $\left(\mathrm{g} / \mathrm{m}^{2}\right)$} \\
\hline B & 0.56 & 0.66 & 0.72 & 0.95 & 0.53 & 0.45 & 0.60 & 0.84 \\
\hline $\mathrm{Na}$ & 0.58 & 0.70 & 0.73 & 0.95 & 0.63 & 0.59 & 0.74 & 0.97 \\
\hline $\mathrm{Si}$ & 0.18 & 0.22 & 0.23 & 0.27 & 0.18 & 0.19 & 0.20 & 0.23 \\
\hline \multicolumn{9}{|c|}{ 7-Day PCT Normalized Loss Rate (g/m²/d) } \\
\hline $\mathrm{B}$ & 0.08 & 0.09 & 0.10 & 0.14 & 0.08 & 0.06 & 0.09 & 0.12 \\
\hline $\mathrm{Na}$ & 0.08 & 0.10 & 0.10 & 0.14 & 0.09 & 0.08 & 0.11 & 0.14 \\
\hline $\mathrm{Si}$ & 0.03 & 0.03 & 0.03 & 0.04 & 0.03 & 0.03 & 0.03 & 0.03 \\
\hline \multicolumn{9}{|c|}{ VHT Alteration $\left(24\right.$ days at $\left.200^{\circ} \mathrm{C}\right)$} \\
\hline Alteration Depth $(\mu \mathrm{m})$ & 324 & 202 & 65 & 387 & 24 & 109 & 113 & 381 \\
\hline Alteration Rate (g/m²/day)* & 36 & 22 & 7 & 43 & 3 & 12 & 12 & 42 \\
\hline
\end{tabular}

* Alteration rates calculated using estimated density of 2.65 g/cc 
Table 2.6. Viscosities and Electrical Conductivities of Three ORPLA Crucible Glasses.

\begin{tabular}{|c|c|c|c|}
\hline \multirow{2}{*}{ Glass ID } & ORPLA18 & ORPLA19 & ORPLA20 \\
\hline \multicolumn{4}{|c|}{ Viscosity (poise) } \\
\hline $900^{\circ} \mathrm{C}$ & 2576 & 2454 & 2379 \\
\hline $950^{\circ} \mathrm{C}$ & 961 & 916 & 872 \\
\hline $1000^{\circ} \mathrm{C}$ & 414 & 393 & 372 \\
\hline $1050^{\circ} \mathrm{C}$ & 200 & 189 & 179 \\
\hline $1100^{\circ} \mathrm{C}$ & 106 & 100 & 95 \\
\hline $1150^{\circ} \mathrm{C}$ & 60 & 57 & 54 \\
\hline $1200^{\circ} \mathrm{C}$ & 37 & 34 & 33 \\
\hline $1250^{\circ} \mathrm{C}$ & 23 & 22 & 21 \\
\hline & $\mathbf{E l e c t r i c a l ~ C o n d u c t i v i t y ~ ( S / c m ) ~}$ \\
\hline $900^{\circ} \mathrm{C}$ & 0.305 & 0.288 & 0.209 \\
\hline $950^{\circ} \mathrm{C}$ & 0.372 & 0.351 & 0.286 \\
\hline $1000^{\circ} \mathrm{C}$ & 0.447 & 0.422 & 0.373 \\
\hline $1050^{\circ} \mathrm{C}$ & 0.530 & 0.500 & 0.469 \\
\hline $1100^{\circ} \mathrm{C}$ & 0.621 & 0.585 & 0.572 \\
\hline $1150^{\circ} \mathrm{C}$ & 0.719 & 0.677 & 0.681 \\
\hline $1200^{\circ} \mathrm{C}$ & 0.824 & 0.776 & 0.794 \\
\hline $1250^{\circ} \mathrm{C}$ & 0.936 & 0.881 & 0.911 \\
\hline
\end{tabular}

Table 2.7. Results of K-3 Corrosion Testing for Four ORPLA Crucible Glasses.

\begin{tabular}{|c|c|c|c|}
\hline Glass ID & $\begin{array}{c}\text { Neck loss } \\
\text { (inches) }\end{array}$ & $\begin{array}{c}\text { Depth of altered } \\
\text { zone (inches) }\end{array}$ & $\begin{array}{c}\text { Half-down loss } \\
\text { (inches) }\end{array}$ \\
\hline ORPLA20 & 0.033 & 0.027 & 0.000 \\
\hline ORPLA21 & 0.061 & 0.021 & $\begin{array}{c}\text { Coupon expanded - } \\
\text { no measurable loss }\end{array}$ \\
\hline ORPLA24 & 0.064 & 0.021 & 0.000 \\
\hline ORPLA25 & 0.089 & 0.023 & 0.000 \\
\hline
\end{tabular}


Table 2.8. Summary of Test Results for Selected ORPLA Glass Formulation ORPLA20 and Comparison to ILAW Requirements.

\begin{tabular}{|c|c|c|}
\hline Test & Requirement [53, 54] & $\begin{array}{l}\text { Test Result for } \\
\text { ORPLA20 }\end{array}$ \\
\hline Density of glass & $<3.7 \mathrm{~g} / \mathrm{cc}$ & $2.59 \mathrm{~g} / \mathrm{Cc}^{*}$ \\
\hline Crystalline Phase & Phase identification & $\begin{array}{c}\text { Clear homogeneous glass } \\
\text { after heat treatment at } 950^{\circ} \mathrm{C} \text { for } 20 \\
\text { hours }\end{array}$ \\
\hline Liquidus & $<950^{\circ} \mathrm{C}$ & $<950^{\circ} \mathrm{C}$ \\
\hline Centerline Canister Cooling & Phase identification & Not measured \\
\hline PCT B $\left(\mathrm{g} / \mathrm{m}^{2}\right)$ & $<2.0 \mathrm{~g} / \mathrm{m}^{2}$ & $0.72 \mathrm{~g} / \mathrm{m}^{2}$ \\
\hline PCT Na $\left(g / m^{2}\right)$ & $<2.0 \mathrm{~g} / \mathrm{m}^{2}$ & $0.73 \mathrm{~g} / \mathrm{m}^{2}$ \\
\hline PCT Si $\left(\mathrm{g} / \mathrm{m}^{2}\right)$ & $<2.0 \mathrm{~g} / \mathrm{m}^{2}$ & $0.23 \mathrm{~g} / \mathrm{m}^{2}$ \\
\hline VHT at $200^{\circ} \mathrm{C}\left(\mathrm{g} / \mathrm{m}^{2} /\right.$ day $)$ & $<50 \mathrm{~g} / \mathrm{m}^{2} /$ day & $7 \mathrm{~g} / \mathrm{m}^{2} /$ day \\
\hline Viscosity (poise) at $1100^{\circ} \mathrm{C}$ & 10 to $150 \mathrm{P}$ & $95 \mathrm{P}$ \\
\hline Conductivity $(\mathrm{S} / \mathrm{cm})$ at $1100^{\circ} \mathrm{C}$ & 0.2 to $0.7 \mathrm{~S} / \mathrm{cm}$ & $0.572 \mathrm{~S} / \mathrm{cm}$ \\
\hline $\mathrm{T}_{\mathrm{G}}\left({ }^{\circ} \mathrm{C}\right)$ & Report for modeling & Not measured \\
\hline
\end{tabular}

* Density measured for melter glass Y10-G-146C of the ORPLA20 composition 
Table 2.9. Oxide Composition of AN-105 Simulant and ORPLA20 Glass Composition Used in Melter Tests (wt\%).

\begin{tabular}{|c|c|c|c|}
\hline Component & $\begin{array}{c}\text { AN-105 waste } \\
\text { contribution }\end{array}$ & $\begin{array}{c}\text { Glass former } \\
\text { additives }\end{array}$ & $\begin{array}{c}\text { ORPLA20 } \\
\text { (for AN-105) }\end{array}$ \\
\hline Loading & $31.4 \%$ & $68.4 \%$ & - \\
\hline $\mathrm{Al}_{2} \mathrm{O}_{3}$ & 5.55 & 1.10 & 6.65 \\
\hline $\mathrm{B}_{2} \mathrm{O}_{3}$ & 0.02 & 8.72 & 8.74 \\
\hline $\mathrm{CaO}$ & - & 3.32 & 3.32 \\
\hline $\mathrm{Cr}_{2} \mathrm{O}_{3}$ & 0.02 & 0.48 & 0.50 \\
\hline $\mathrm{Fe}_{2} \mathrm{O}_{3}$ & - & 0.19 & 0.19 \\
\hline $\mathrm{K}_{2} \mathrm{O}$ & 0.53 & - & 0.53 \\
\hline $\mathrm{MgO}$ & - & 0.93 & 0.92 \\
\hline $\mathrm{Na}_{2} \mathrm{O}^{(\mathrm{a})}$ & $23.25+0.55^{(1)}+0.20^{(2)}$ & - & 24.00 \\
\hline $\mathrm{SiO}_{2}$ & 0.03 & 42.3 & 42.33 \\
\hline $\mathrm{SnO}_{2}$ & - & 2.74 & 2.74 \\
\hline $\mathrm{ZnO}$ & - & 2.74 & 2.74 \\
\hline $\mathrm{ZrO}_{2}$ & - & 5.96 & 5.96 \\
\hline $\mathrm{Cl}$ & 0.67 & - & 0.67 \\
\hline $\mathrm{F}$ & 0.000 & - & 0.00 \\
\hline $\mathrm{P}_{2} \mathrm{O}_{5}$ & 0.000 & - & 0.00 \\
\hline $\mathrm{SO}_{3}^{(b)}$ & $0.70^{(1)}$ & - & 0.70 \\
\hline SUM & 31.5 & 68.5 & 100.0 \\
\hline
\end{tabular}

(a) Simulant was ordered at a concentration of $23.41 \mathrm{wt} \% \mathrm{Na}_{2} \mathrm{O}$ and modified before each melter test with (1) $\mathrm{Na}_{2} \mathrm{SO}_{4}$ and (2) $\mathrm{NaOH}$ additions to obtain $24 \mathrm{wt} \% \mathrm{Na}_{2} \mathrm{O}$ in the glass.

(b) Concentration of $\mathrm{SO}_{3}$ was increased in steps during the melter tests from $0.1 \mathrm{wt} \% \mathrm{SO}_{3}$ in the glass up to $0.7 \mathrm{wt} \%$.

- Empty data field 
Table 2.10a. Glass Former Additives for 1 Liter of AN-105 Simulant (8 M Na) and Corresponding Melter Feed Properties.

\begin{tabular}{|c|c|}
\hline Additives Source & Feed ORPLA20 \\
\hline Additives in Glass (wt\%) & 68.6 \\
\hline Kyanite $\left(\mathrm{Al}_{2} \mathrm{SiO}_{5}\right) 325$ Mesh (Kyanite Mining) (g) & 18.51 \\
\hline $\mathrm{H}_{3} \mathrm{BO}_{3}$ (US Borax - Technical Granular) (g) & 160.46 \\
\hline Wollanstonite NYAD 325 Mesh (NYCO Minerals) (g) & 72.57 \\
\hline $\mathrm{Cr}_{2} \mathrm{O}_{3}$ oxide & $5.06^{(1)}$ \\
\hline Olivine $\left(\mathrm{Mg}_{2} \mathrm{SiO}_{4}\right) 325 \mathrm{Mesh}(\# 180$ Unimin) (g) & 20.13 \\
\hline $\mathrm{SiO}_{2}$ (Sil-co-Sil 75 US Silica) (g) & 354.47 \\
\hline $\mathrm{SnO}_{2}$ - Stannous Oxide - Mason color ${ }^{(2)}$ & 28.57 \\
\hline ZnO (KADOX - 920 Zinc Corp. of America) (g) & 28.37 \\
\hline Zircon $\mathrm{ZrSiO}_{4}$ (Flour) Mesh 325 (AM. Mineral) (g) & 92.64 \\
\hline $\mathrm{Na}_{2} \mathrm{SO}_{4}$ & Variable - Table 2.10b \\
\hline Addition of Sucrose as Reductant (g) & 78.5 \\
\hline Simulant Weight for 1 liter (g) & 1359 \\
\hline Sum of Additives (g) & 962 \\
\hline Sum of Complete Batch (g) & 2218 \\
\hline Target Final Volume (l) & 1.38 \\
\hline Estimated Density (g/ml) & 1.61 \\
\hline Target Glass Produced (g) & 1033 \\
\hline Target Weight \% Additives in Slurry & 39 \\
\hline Target Glass Yield (g/kg of Feed) & 466 \\
\hline Target Glass Yield (g/l of Feed) & 750 \\
\hline Target Total Solids (g/l of Feed) & 969 \\
\hline Target Additives (g/l of Feed) & 624 \\
\hline
\end{tabular}

Table 2.10b. $\mathrm{NaOH}$ and $\mathrm{Na}_{2} \mathrm{SO}_{4}$ Additions Required to Obtain 24 wt\% $\mathrm{Na}_{2} \mathrm{O}$ and Various $\mathrm{SO}_{3}$ Concentrations in the ORPLA20 Glass.

\begin{tabular}{|c|c|c|}
\hline $\begin{array}{c}\text { Final } \\
\mathrm{SO}_{3}(\mathrm{wt} \%)\end{array}$ & $\begin{array}{c}\text { NaOH needed } \\
\text { per kg of feed } \\
\text { (grams) }\end{array}$ & $\begin{array}{c}\mathrm{Na}_{2} \mathrm{SO}_{4} \text { needed } \\
\text { per kg of feed } \\
\text { (grams) }\end{array}$ \\
\hline 0.2 & 7.13 & 1.69 \\
\hline 0.3 & 6.19 & 2.53 \\
\hline 0.4 & 5.25 & 3.37 \\
\hline 0.5 & 4.31 & 4.22 \\
\hline 0.6 & 3.38 & 5.06 \\
\hline 0.7 & 2.44 & 5.90 \\
\hline 0.8 & 1.50 & 6.75 \\
\hline 0.9 & 0.56 & 7.59 \\
\hline
\end{tabular}


Table 2.11. LAW Sub-Envelope C2 (AN-102) Simulant Recipe at 8 Molar Sodium.

\begin{tabular}{|c|c|c|c|c|c|c|c|c|c|}
\hline $\begin{array}{c}\text { Envelope } \\
\text { Constituents }\end{array}$ & \multicolumn{2}{|c|}{$\begin{array}{c}\text { Simulant AN-102 } \\
\text { Including Pretreatment }\end{array}$} & $\begin{array}{l}\text { Glass } \\
\text { Oxides }\end{array}$ & $\begin{array}{c}\text { AN-102 } \\
\text { Simulant as } \\
\text { Oxides (wt\%) }\end{array}$ & Source in Simulant & $\begin{array}{l}\text { Order for } \\
\text { Addition }\end{array}$ & $\begin{array}{l}\text { Formula } \\
\text { Weight }\end{array}$ & Assay* & $\begin{array}{c}\text { Target } \\
\text { Weight (g) }\end{array}$ \\
\hline- & $\mathrm{mg} / \mathrm{L}$ & Molarity & Loading & - & In $430 \mathrm{ml}$ water add follo & pounds in th & rder listed & low & \\
\hline $\mathrm{Al}$ & 9922 & 0.368 & $\mathrm{Al}_{2} \mathrm{O}_{3}$ & 6.44 & $\mathrm{Al}\left(\mathrm{NO}_{3}\right)_{3} .9 \mathrm{H}_{2} \mathrm{O}, 60 \%$ sol. & 1 & 375.14 & 0.61 & 227.31 \\
\hline $\mathrm{B}$ & 30 & 0.003 & $\mathrm{~B}_{2} \mathrm{O}_{3}$ & 0.03 & H3ВO3 & 5 & 61.83 & 0.99 & 0.17 \\
\hline $\mathrm{Ca}$ & 396 & 0.010 & $\mathrm{CaO}$ & 0.19 & $\mathrm{Ca}\left(\mathrm{NO}_{3}\right)_{2} * 4 \mathrm{H}_{2} \mathrm{O}$ & 2 & 236.16 & 0.99 & 2.33 \\
\hline $\mathrm{Cr}$ & 174 & 0.003 & $\mathrm{Cr}_{2} \mathrm{O}_{3}$ & 0.09 & $\mathrm{Na}_{2} \mathrm{CrO}_{4} * 4 \mathrm{H}_{2} \mathrm{O}$ & 8 & 234.04 & 0.99 & 0.79 \\
\hline $\mathrm{K}$ & 1604 & 0.041 & $\mathrm{~K}_{2} \mathrm{O}$ & 0.66 & $\mathrm{KOH}$ & 7 & 56.10 & 0.91 & 2.53 \\
\hline $\mathrm{Na}$ & 183920 & 8.000 & $\mathrm{Na}_{2} \mathrm{O}$ & 85.22 & $\mathrm{NaOH}, 50 \%$ sol. $\mathrm{D}=1.53$ & 6 & 40.00 & 0.50 & 160.33 \\
\hline $\mathrm{Ni}$ & 337 & 0.006 & $\mathrm{NiO}$ & 0.15 & $\mathrm{Ni}\left(\mathrm{NO}_{3}\right)_{2} * 6 \mathrm{H}_{2} \mathrm{O}$ & 4 & 290.81 & 1.00 & 1.70 \\
\hline $\mathrm{Pb}$ & 150 & 0.001 & $\mathrm{PbO}$ & 0.06 & $\mathrm{PbO}$ & 9 & 223.20 & 1.00 & 0.16 \\
\hline $\mathrm{Si}$ & 73 & 0.003 & $\mathrm{SiO}_{2}$ & 0.05 & $\mathrm{SiO}_{2}$ & 10 & 60.09 & 0.99 & 0.16 \\
\hline $\mathrm{Cl}$ & 3904 & 0.110 & $\mathrm{Cl}$ & 1.34 & $\mathrm{NaCl}$ & 11 & 58.45 & 0.99 & 6.50 \\
\hline $\mathrm{F}$ & 2025 & 0.107 & $\mathrm{~F}$ & 0.70 & $\mathrm{NaF}$ & 12 & 42.00 & 0.99 & 4.52 \\
\hline $\mathrm{PO}_{4}$ & 4508 & 0.047 & $\mathrm{P}_{2} \mathrm{O}_{5}$ & 1.16 & $\mathrm{Na}_{3} \mathrm{PO}_{4} \cdot 12 \mathrm{H}_{2} \mathrm{O}$ & 13 & 380.12 & 0.99 & 17.94 \\
\hline $\mathrm{SO}_{4}(\text { Nominal })^{\$}$ & 13648 & 0.142 & $\mathrm{SO}_{3}$ & 3.91 & $\mathrm{Na}_{2} \mathrm{SO}_{4}$ & 14 & 142.06 & 0.99 & $20.39^{\$}$ \\
\hline $\mathrm{NO}_{2}$ & 169129 & 1.503 & $\mathrm{NO}_{2}$ & - & $\mathrm{NaNO}_{2}$ & 20 & 69.00 & 1.00 & 104.21 \\
\hline $\mathrm{NO}_{3}$ & 178997 & 2.887 & $\mathrm{NO}_{3}$ & - & $\mathrm{NaNO}_{3}$ & 21 & 84.99 & 0.99 & 149.84 \\
\hline $\mathrm{CO}_{3}$ & 44356 & 0.739 & $\mathrm{CO}_{3}$ & - & $\mathrm{Na}_{2} \mathrm{CO}_{3}$ & 22 & 105.99 & 1.00 & 78.34 \\
\hline $\mathrm{NH}_{3}$ & 123 & 0.007 & $\mathrm{NH}_{3}$ & - & $\mathrm{NH}_{4} \mathrm{NO}_{3}$ & 19 & 80.04 & 1.00 & 0.58 \\
\hline Org.Carbon & 23569 & 1.964 & - & - & - & - & - & - & - \\
\hline Formate & 26113 & 0.580 & - & - & Sodium Formate (C1) & 15 & 68.01 & 0.99 & 39.85 \\
\hline Oxalate & 1501 & 0.017 & - & - & Sodium Oxalate (C2) & 16 & 134.00 & 0.99 & 2.31 \\
\hline Glycolate & 34273 & 0.451 & - & - & Glycolic Acid (C2) & 17 & 76.05 & 0.71 & 48.34 \\
\hline Citric Acid & 14362 & 0.075 & - & - & Citric Acid (C6) & 18 & 192.12 & 0.99 & 14.51 \\
\hline- & - & - & SUM & 100.000 & Total Simulant Weight & & & & 1312.83 \\
\hline
\end{tabular}

- Empty data field.

* Assay refers to the purity of the raw material as specified by the vendor.

${ }^{\$} \mathrm{SO}_{3}$ content varied during each run, as given in Table 2.20b. The value given here corresponds to the nominal. 
Table 2.12. Target and Analyzed Compositions (wt\%) of Six ORPLD Crucible Glasses.

\begin{tabular}{|c|c|c|c|c|c|c|c|c|c|c|c|c|}
\hline \multirow{2}{*}{$\begin{array}{c}\text { GLASS } \\
\text { Oxides }\end{array}$} & \multicolumn{2}{|c|}{ ORPLD4 } & \multicolumn{2}{|c|}{ ORPLD5 } & \multicolumn{2}{|c|}{ ORPLD6 } & \multicolumn{2}{|c|}{ ORPLD7 } & \multicolumn{2}{|c|}{ ORPLD8 } & \multicolumn{2}{|c|}{ ORPLD9 } \\
\hline & Target & Analyzed* & Target & Analyzed* & Target & Analyzed ${ }^{*}$ & Target & Analyzed $^{*}$ & Target & Analyzed* & Target & Analyzed ${ }^{*}$ \\
\hline $\mathrm{Al}_{2} \mathrm{O}_{3}$ & 10.18 & 9.92 & 10.18 & 9.87 & 10.12 & 9.81 & 10.08 & 9.86 & 10.03 & 9.84 & 8.57 & 8.41 \\
\hline $\mathrm{B}_{2} \mathrm{O}_{3}$ & 12.07 & 12.86 & 10.03 & 10.62 & 9.87 & 10.32 & 9.87 & 10.10 & 9.50 & 10.05 & 9.50 & 10.10 \\
\hline $\mathrm{CaO}$ & 8.03 & 8.14 & 8.03 & 8.11 & 7.91 & 8.08 & 7.91 & 8.01 & 7.35 & 7.71 & 7.35 & 7.22 \\
\hline $\mathrm{Cr}_{2} \mathrm{O}_{3}$ & 0.50 & 0.69 & 0.50 & 0.69 & 0.50 & 0.70 & 0.50 & 0.70 & 0.50 & 0.65 & 0.50 & 0.60 \\
\hline $\mathrm{Fe}_{2} \mathrm{O}_{3}$ & 0.30 & 0.37 & 0.30 & 0.36 & 0.30 & 0.35 & 0.30 & 0.35 & 0.29 & 0.32 & 0.29 & 0.29 \\
\hline $\mathrm{K}_{2} \mathrm{O}$ & 0.16 & 0.17 & 0.16 & 0.17 & 0.17 & 0.17 & 0.17 & 0.18 & 0.18 & 0.18 & 0.18 & 0.17 \\
\hline $\mathrm{MgO}$ & 1.00 & 0.89 & 1.00 & 0.92 & 0.99 & 0.85 & 0.99 & 0.88 & 0.97 & 0.85 & 0.97 & 0.99 \\
\hline $\mathrm{Na}_{2} \mathrm{O}$ & 21.00 & 20.30 & 21.00 & 20.65 & 22.00 & 21.48 & 22.00 & 21.49 & 23.00 & 22.04 & 23.00 & 23.71 \\
\hline $\mathrm{NiO}$ & 0.04 & 0.04 & 0.04 & 0.04 & 0.04 & 0.04 & 0.04 & 0.05 & 0.04 & 0.04 & 0.04 & 0.04 \\
\hline $\mathrm{PbO}$ & 0.01 & 0.01 & 0.01 & 0.02 & 0.01 & 0.02 & 0.01 & 0.02 & 0.02 & 0.03 & 0.02 & 0.02 \\
\hline $\mathrm{SiO}_{2}$ & 37.92 & 38.38 & 37.92 & 37.77 & 37.33 & 37.34 & 37.33 & 37.45 & 36.74 & 37.06 & 36.74 & 36.69 \\
\hline $\mathrm{SnO}_{2}$ & 0.00 & 0.00 & 0.00 & 0.00 & 0.00 & 0.00 & 1.00 & 1.18 & 1.00 & 1.12 & 1.00 & 1.14 \\
\hline $\mathrm{V}_{2} \mathrm{O}_{5}$ & 1.00 & 1.24 & 2.00 & 2.49 & 1.97 & 2.50 & 1.00 & 1.29 & 1.46 & 1.59 & 2.92 & 2.96 \\
\hline $\mathrm{ZnO}$ & 3.01 & 3.17 & 3.01 & 3.21 & 2.97 & 3.22 & 2.97 & 3.16 & 2.99 & 3.07 & 2.99 & 2.82 \\
\hline $\mathrm{ZrO}_{2}$ & 3.01 & 3.00 & 4.05 & 4.04 & 3.99 & 3.91 & 3.99 & 3.81 & 4.02 & 3.88 & 4.02 & 3.60 \\
\hline $\mathrm{Cl}$ & 0.33 & 0.33 & 0.33 & 0.31 & 0.35 & 0.32 & 0.35 & 0.32 & 0.36 & 0.36 & 0.36 & 0.35 \\
\hline $\mathrm{F}$ & 0.17 & NA & 0.17 & NA & 0.18 & NA & 0.18 & NA & 0.19 & NA & 0.19 & NA \\
\hline $\mathrm{P}_{2} \mathrm{O}_{5}$ & 0.29 & 0.31 & 0.29 & 0.31 & 0.30 & 0.32 & 0.30 & 0.35 & 0.31 & 0.36 & 0.31 & 0.33 \\
\hline $\mathrm{SO}_{3}$ & 0.96 & 0.85 & 0.96 & 0.83 & 1.01 & 0.82 & 1.01 & 0.87 & 1.06 & 1.21 & 1.06 & 0.99 \\
\hline SUM & 100.0 & 100.8 & 100.0 & 100.6 & 100.0 & 100.4 & 100.0 & 100.2 & 100.0 & 100.5 & 100.0 & 100.6 \\
\hline
\end{tabular}

* - Analyzed by X-ray fluorescence except for boron which was measured by DCP NA - Not analyzed (SUM includes target fluorine value) 
Table 2.13. Descriptions of Six As-Melted and Heat Treated ORPLD Crucible Glasses.

\begin{tabular}{|c|l|c|}
\hline Glass ID & As-melted glass & $\begin{array}{c}\text { Glass remelted at 1200 }{ }^{\circ} \text { C for 1 hour, } \\
\text { heat treated for 20 hours at 950 }{ }^{\circ} \text { and quenched. }\end{array}$ \\
\hline ORPLD4 & Mostly clear glass. $\sim 0.1$ vol\% of small Cr+Zn crystals & Clear glass \\
\hline ORPLD5 & Mostly clear glass. $\sim 0.1$ vol\% of small Cr+Zn crystals & Mostly clear glass $\sim 0.3$ vol\% Large sodalite (Na,Ca,Al silicate with S \&Cr) \\
\hline ORPLD6 & Mostly clear glass. $<0.1$ vol\% of small Cr+Zn crystals & Mostly clear glass $\sim 0.3$ vol\% Large sodalite (Na,Ca,Al silicate with S \&Cr) \\
\hline ORPLD7 & Mostly clear glass. $<0.1$ vol\% of small Cr+Zn crystals & Mostly clear glass $~ 0.2$ vol\% Large sodalite (Na,Ca,Al silicate with S \&Cr) \\
\hline ORPLD8 & Mostly clear glass. $<0.1$ vol\% of small Cr+Zn crystals & Mostly clear glass $~ 0.3$ vol\% Large sodalite (Na,Ca,Al silicate with S \&Cr) \\
\hline ORPLD9 & Mostly clear glass. < 0.1 vol\% of small Cr+Zn crystals & Clear glass + submicron Au-Pt crystals \\
\hline
\end{tabular}


Table 2.14. Measured Sulfate Solubility Limits in Six ORPLD Crucible Glasses.

\begin{tabular}{|c|c|c|}
\hline \multirow{2}{*}{ Sample ID } & \multicolumn{2}{|c|}{ SO $_{3}$ Content (wt \%) } \\
\cline { 2 - 3 } & \multicolumn{2}{|c|}{ Batch Saturation } \\
\cline { 2 - 3 } & As-Melted & After Acid Wash \\
\hline ORPLD4S4 & 1.08 & 0.94 \\
\hline ORPLD5S4 & 1.03 & 0.86 \\
\hline ORPLD6S4 & 1.11 & 0.89 \\
\hline ORPLD7S4 & 1.07 & 0.87 \\
\hline ORPLD8S4 & 1.13 & 0.88 \\
\hline ORPLD9S4 & 1.14 & 0.95 \\
\hline
\end{tabular}


Table 2.15. Results of 7-day PCT (at $90^{\circ} \mathrm{C}$ ) and VHT (at $200^{\circ} \mathrm{C}$ for 24 Days) for Six ORPLD Crucible Glasses.

\begin{tabular}{|c|c|c|c|c|c|c|}
\hline Glass ID & ORPLD4 & ORPLD5 & ORPLD6 & ORPLD7 & ORPLD8 & ORPLD9 \\
\hline \multicolumn{7}{|c|}{ 7-Day PCT, Stainless Steel Vessel; S/V=2000m ${ }^{-1}$ (ppm) } \\
\hline $\mathrm{B}$ & 43.46 & 31.38 & 34.64 & 35.36 & 40.64 & 44.62 \\
\hline $\mathrm{Na}$ & 205.90 & 195.90 & 219.60 & 228.70 & 268.80 & 287.10 \\
\hline Si & 56.04 & 56.39 & 63.40 & 63.13 & 69.30 & 76.22 \\
\hline \multicolumn{7}{|l|}{ Normalized Concentrations (g/L) } \\
\hline $\mathrm{B}$ & 1.16 & 1.01 & 1.13 & 1.15 & 1.38 & 1.51 \\
\hline $\mathrm{Na}$ & 1.32 & 1.26 & 1.35 & 1.40 & 1.58 & 1.68 \\
\hline Si & 0.32 & 0.32 & 0.36 & 0.36 & 0.40 & 0.44 \\
\hline $\mathrm{pH}$ & 11.46 & 11.58 & 11.67 & 11.71 & 11.77 & 11.78 \\
\hline \multicolumn{7}{|c|}{ 7-Day PCT Normalized Mass Loss $\left(\mathrm{g} / \mathrm{m}^{2}\right)$} \\
\hline B & 0.58 & 0.50 & 0.56 & 0.58 & 0.69 & 0.76 \\
\hline $\mathrm{Na}$ & 0.66 & 0.63 & 0.67 & 0.70 & 0.79 & 0.84 \\
\hline Si & 0.16 & 0.16 & 0.18 & 0.18 & 0.20 & 0.22 \\
\hline \multicolumn{7}{|c|}{ 7-Day PCT Normalized Loss Rate (g/m²/d) } \\
\hline $\mathrm{B}$ & 0.08 & 0.07 & 0.08 & 0.08 & 0.10 & 0.11 \\
\hline $\mathrm{Na}$ & 0.09 & 0.09 & 0.10 & 0.10 & 0.11 & 0.12 \\
\hline $\mathrm{Si}$ & 0.02 & 0.02 & 0.03 & 0.03 & 0.03 & 0.03 \\
\hline \multicolumn{7}{|c|}{ VHT Alteration (24 days at $200^{\circ} \mathrm{C}$ ) } \\
\hline Alteration Depth $(\mu \mathrm{m})$ & 122 & 131 & 164 & 134 & 116 & 377 \\
\hline Alteration Rate (g/m²/day)* & 13 & 14 & 18 & 15 & 13 & 42 \\
\hline
\end{tabular}

* Alteration rates calculated using estimated density of $2.65 \mathrm{~g} / \mathrm{cc}$ 
Table 2.16. Viscosities and Electrical Conductivities of Six ORPLD Crucible Glasses.

\begin{tabular}{|c|c|c|c|c|c|c|}
\hline Glass ID & ORPLD4 & ORPLD5 & ORPLD6 & ORPLD7 & ORPLD8 & ORPLD9 \\
\hline Viscosity (poise) & & & & & & \\
\hline $900^{\circ} \mathrm{C}$ & 662 & 952 & 691 & 881 & 794 & 549 \\
\hline $950^{\circ} \mathrm{C}$ & 282 & 393 & 302 & 366 & 330 & 242 \\
\hline $1000^{\circ} \mathrm{C}$ & 138 & 187 & 149 & 172 & 156 & 119 \\
\hline $1050^{\circ} \mathrm{C}$ & 75 & 99 & 81 & 90 & 82 & 65 \\
\hline $1100^{\circ} \mathrm{C}$ & 44 & 57 & 48 & 51 & 47 & 38 \\
\hline $1150^{\circ} \mathrm{C}$ & 28 & 36 & 30 & 31 & 29 & 23 \\
\hline $1200^{\circ} \mathrm{C}$ & 19 & 23 & 20 & 20 & 19 & 15 \\
\hline $1250^{\circ} \mathrm{C}$ & 13 & 16 & 14 & 13 & 13 & 10 \\
\hline Electrical & & & & & & \\
\hline Conductivity (S/cm) & & & & & 0.191 & 0.188 \\
\hline $900^{\circ} \mathrm{C}$ & 0.155 & 0.164 & 0.189 & 0.171 & 0.191 \\
\hline $950^{\circ} \mathrm{C}$ & 0.196 & 0.207 & 0.232 & 0.209 & 0.240 & 0.248 \\
\hline $1000^{\circ} \mathrm{C}$ & 0.242 & 0.255 & 0.280 & 0.252 & 0.295 & 0.314 \\
\hline $1050^{\circ} \mathrm{C}$ & 0.295 & 0.310 & 0.334 & 0.300 & 0.354 & 0.386 \\
\hline $1100^{\circ} \mathrm{C}$ & 0.354 & 0.371 & 0.392 & 0.351 & 0.418 & 0.462 \\
\hline $1150^{\circ} \mathrm{C}$ & 0.420 & 0.439 & 0.456 & 0.407 & 0.487 & 0.542 \\
\hline $1200^{\circ} \mathrm{C}$ & 0.493 & 0.514 & 0.524 & 0.466 & 0.559 & 0.625 \\
\hline $1250^{\circ} \mathrm{C}$ & 0.571 & 0.595 & 0.597 & 0.530 & 0.635 & 0.710 \\
\hline
\end{tabular}

Table 2.17. Results of K-3 Corrosion Testing for Four ORPLD Crucible Glasses.

\begin{tabular}{|c|c|c|c|}
\hline Glass ID & $\begin{array}{c}\text { Neck loss } \\
\text { (inches) }\end{array}$ & $\begin{array}{c}\text { Depth of altered } \\
\text { zone (inches) }\end{array}$ & $\begin{array}{c}\text { Half-down loss } \\
\text { (inches) }\end{array}$ \\
\hline ORPLD6 & 0.040 & 0.028 & $\begin{array}{c}\text { Coupon expanded - } \\
\text { no measurable loss }\end{array}$ \\
\hline ORPLD7 & 0.047 & 0.026 & $\begin{array}{c}\text { Coupon expanded - } \\
\text { no measurable loss }\end{array}$ \\
\hline ORPLD8 & 0.066 & 0.028 & 0.001 \\
\hline ORPLD9 & 0.063 & 0.028 & 0.001 \\
\hline
\end{tabular}


The Catholic University of America Vitreous State Laboratory
Glass Formulation Development and DM10 Melter Testing with ORP LAW Glasses

Final Report, VSL-09R1510-2, Rev. 0

Table 2.18. Summary of Test Results for Selected ORPLD Glass Formulation ORPLD6 and Comparison to ILAW Requirements.

\begin{tabular}{|c|c|c|}
\hline Test & Requirement [53, 54] & $\begin{array}{c}\text { Test Result for } \\
\text { ORPLD }\end{array}$ \\
\hline Density of glass & $<3.7 \mathrm{~g} / \mathrm{cc}$ & $2.57 \mathrm{~g} / \mathrm{cc}$ \\
\hline Crystalline Phase & Phase identification & $\begin{array}{c}\text { Clear homogeneous glass } \\
\text { with not more than } 0.2 \text { vol\% crystals on average } \\
\text { after heat treatment at } 950^{\circ} \mathrm{C} \text { for } 20 \text { hours }\end{array}$ \\
\hline Liquidus & $<950^{\circ} \mathrm{C}$ & $<950^{\circ} \mathrm{C}$ \\
\hline Centerline Canister Cooling & Phase identification & $0.56 \mathrm{~g} / \mathrm{m}^{2}$ \\
\hline PCT B $\left(\mathrm{g} / \mathrm{m}^{2}\right)$ & $<2.0 \mathrm{~g} / \mathrm{m}^{2}$ & $0.67 \mathrm{~g} / \mathrm{m}^{2}$ \\
\hline PCT Na $\left(\mathrm{g} / \mathrm{m}^{2}\right)$ & $<2.0 \mathrm{~g} / \mathrm{m}^{2}$ & $0.18 \mathrm{~g} / \mathrm{m}^{2}$ \\
\hline PCT Si $\left(\mathrm{g} / \mathrm{m}^{2}\right)$ & $<2.0 \mathrm{~g} / \mathrm{m}^{2}$ & $18 \mathrm{~g} / \mathrm{m}^{2} / \mathrm{day}$ \\
\hline VHT at $200^{\circ} \mathrm{C}\left(\mathrm{g} / \mathrm{m}^{2} / \mathrm{day}\right)$ & $<50 \mathrm{~g} / \mathrm{m}^{2} / \mathrm{day}$ & $48 \mathrm{P}$ \\
\hline Viscosity (poise) at $1100^{\circ} \mathrm{C}$ & 10 to $150 \mathrm{P}$ & $0.392 \mathrm{~S} / \mathrm{cm}^{2}$ \\
\hline Conductivity $(\mathrm{S} / \mathrm{cm})$ at $1100^{\circ} \mathrm{C}$ & 0.2 to $0.7 \mathrm{~S} / \mathrm{cm}$ & Not measured \\
\hline $\mathrm{T}_{\mathrm{G}}\left({ }^{\circ} \mathrm{C}\right)$ & Report for modeling & \\
\hline
\end{tabular}

"Density measured for melter glass 10A-G-53C of the ORPLD6 composition 
Table 2.19. Oxide Composition of AN-102 Simulant and ORPLD6 Glass Composition Used in Melter Tests (wt\%).

\begin{tabular}{|c|c|c|c|}
\hline Component & AN-102 waste contribution & $\begin{array}{c}\text { Glass former } \\
\text { additives }\end{array}$ & $\begin{array}{c}\text { ORPLD6 } \\
\text { (for AN-102) }\end{array}$ \\
\hline Loading & $25.89 \%$ & $74.11 \%$ & - \\
\hline $\mathrm{Al}_{2} \mathrm{O}_{3}$ & 1.55 & 8.56 & 10.09 \\
\hline $\mathrm{B}_{2} \mathrm{O}_{3}$ & 0.01 & 9.85 & 9.85 \\
\hline $\mathrm{CaO}$ & 0.05 & 7.86 & 7.89 \\
\hline $\mathrm{Cr}_{2} \mathrm{O}_{3}$ & 0.02 & 0.48 & 0.50 \\
\hline $\mathrm{Fe}_{2} \mathrm{O}_{3}$ & - & 0.28 & 0.28 \\
\hline $\mathrm{K}_{2} \mathrm{O}$ & 0.17 & - & 0.17 \\
\hline $\mathrm{MgO}$ & - & 1.00 & 1.00 \\
\hline $\mathrm{Na}_{2} \mathrm{O}^{(\mathrm{a})}$ & $20.44+0.93^{(1)}+0.63^{(2)}$ & - & 22.00 \\
\hline $\mathrm{NiO}$ & 0.04 & - & 0.04 \\
\hline $\mathrm{PbO}$ & 0.01 & - & 0.01 \\
\hline $\mathrm{SiO}_{2}$ & 0.01 & 37.26 & 37.24 \\
\hline $\mathrm{V}_{2} \mathrm{O}_{5}$ & - & 1.96 & 1.96 \\
\hline $\mathrm{ZnO}$ & - & 2.96 & 2.96 \\
\hline $\mathrm{ZrO}_{2}$ & - & 3.99 & 3.98 \\
\hline $\mathrm{Cl}$ & 0.35 & - & 0.35 \\
\hline $\mathrm{F}$ & 0.18 & - & 0.18 \\
\hline $\mathrm{P}_{2} \mathrm{O}_{5}$ & 0.30 & - & 0.30 \\
\hline $\mathrm{SO}_{3}{ }^{(\mathrm{b})}$ & $1.20^{(1)}$ & - & 1.20 \\
\hline SUM & 25.9 & 74.1 & 100.0 \\
\hline
\end{tabular}

(a) Simulant was ordered at a concentration of $19.37 \mathrm{wt} \% \mathrm{Na}_{2} \mathrm{O}$ and modified before each melter test with (1) $\mathrm{Na}_{2} \mathrm{SO}_{4}$ and (2) $\mathrm{NaOH}$ additions to obtain $21.0 \mathrm{wt} \% \mathrm{Na}_{2} \mathrm{O}$ in the glass.

(b) Concentration of $\mathrm{SO}_{3}$ was increased in steps during the melter tests from $0.7 \mathrm{wt} \% \mathrm{SO}_{3}$ in the glass up to $1.3 \mathrm{wt} \%$.

- Empty data field 
Table 2.20a. Glass Former Additives for 1 Liter of AN-102 Simulant (8 M Na) and Corresponding Melter Feed Properties.

\begin{tabular}{|c|c|}
\hline Additives Source & Feed ORPLD6 \\
\hline Additives in Glass (wt\%) & 74.1 \\
\hline Kyanite $\left(\mathrm{Al}_{2} \mathrm{SiO}_{5}\right) 325$ Mesh (Kyanite Mining) (g) & 166.51 \\
\hline $\mathrm{H}_{3} \mathrm{BO}_{3}$ (US Borax - Technical Granular) (g) & 197.69 \\
\hline Wollanstonite NYAD 325 Mesh (NYCO Minerals) (g) & 187.03 \\
\hline $\mathrm{Cr}_{2} \mathrm{O}_{3}$ oxide & 5.49 \\
\hline $\mathrm{Fe}_{2} \mathrm{O}_{3}$ (Prince Manufacturing) (g) & 0 \\
\hline Olivine $\left(\mathrm{Mg}_{2} \mathrm{SiO}_{4}\right) 325 \mathrm{Mesh}(\# 180$ Unimin) (g) & 20.49 \\
\hline $\mathrm{SiO}_{2}$ (Sil-co-Sil 75 US Silica) (g) & 223.78 \\
\hline $\mathrm{V}_{2} \mathrm{O}_{5}-$ Pulva Ground - Stratcor & 22.15 \\
\hline ZnO (KADOX - 920 Zinc Corp. of America) (g) & 33.47 \\
\hline Zircon $\mathrm{ZrSiO}_{4}$ (Flour) Mesh 325 (AM. Mineral) (g) & 67.55 \\
\hline $\mathrm{Na}_{2} \mathrm{SO}_{4}$ & Variable - Table 2.20b \\
\hline Addition of Sucrose as Reductant (g) & 37.86 \\
\hline Simulant Weight for 1 liter (g) & 1313 \\
\hline Sum of Additives (g) & 962 \\
\hline Sum of Complete Batch (g) & 2275 \\
\hline Target Final Volume (l) & 1.34 \\
\hline Estimated Density (g/ml) & 1.70 \\
\hline Target Glass Produced (g) & 1127 \\
\hline Target Weight \% Additives in Slurry & 42 \\
\hline Target Glass Yield (g/kg of Feed) & 495 \\
\hline Target Glass Yield (g/l of Feed) & 842 \\
\hline Target Total Solids (g/l of Feed) & 1068 \\
\hline Target Additives (g/l of Feed) & 719 \\
\hline
\end{tabular}

Table 2.20b. $\mathrm{NaOH}$ and $\mathrm{Na}_{2} \mathrm{SO}_{4}$ Additions Required to Obtain $22 \mathrm{wt} \% \mathrm{Na}_{2} \mathrm{O}$ and Various $\mathrm{SO}_{3}$ Concentrations in the ORPLD6 Glass.

\begin{tabular}{|c|c|c|}
\hline $\begin{array}{c}\text { Final } \\
\mathrm{SO}_{3}(\mathrm{wt} \%)\end{array}$ & $\begin{array}{c}\mathrm{NaOH} \text { needed } \\
\text { per kg of feed } \\
\text { (grams) }\end{array}$ & $\begin{array}{c}\mathrm{Na}_{2} \mathrm{SO}_{4} \text { needed } \\
\text { per kg of feed } \\
\text { (grams) }\end{array}$ \\
\hline 0.0 & 20.20 & - \\
\hline 0.7 & 13.16 & 6.33 \\
\hline 0.8 & 12.16 & 7.23 \\
\hline 0.9 & 11.15 & 8.14 \\
\hline 1.0 & 10.15 & 9.04 \\
\hline 1.1 & 9.14 & 9.95 \\
\hline 1.2 & 8.14 & 10.85 \\
\hline 1.3 & 7.13 & 11.76 \\
\hline
\end{tabular}


Table 2.21. LAW Sub-Envelope B2 (AZ-102) Waste Simulant Recipe at 5.5 Molar Sodium.

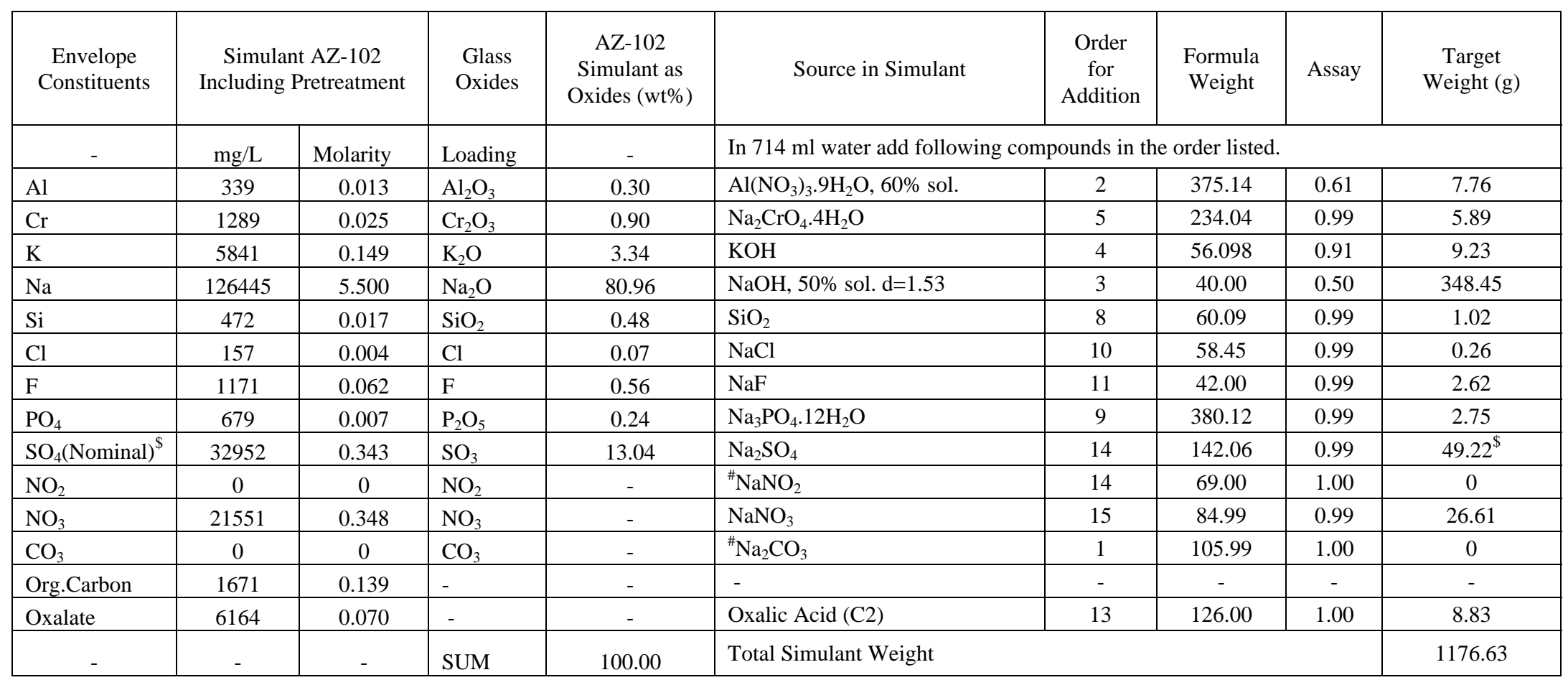

- Empty data field.

* Assay refers to the purity of the raw material as specified by the vendor.

$\# \mathrm{Na}_{2} \mathrm{CO}_{3}$ and $\mathrm{NaNO}_{2}$ were omitted to accommodate sulfate addition as $\mathrm{Na}_{2} \mathrm{SO}_{4}$ without excessive decrease in the amount of added $\mathrm{NaOH}$

${ }^{\$} \mathrm{SO}_{3}$ content varied during each run, as given in Table 2.30b. The value given here corresponds to the nominal. 
Table 2.22. Target and Analyzed Compositions (wt\%) of Fourteen ORPLF Crucible Glasses.

\begin{tabular}{|c|c|c|c|c|c|c|c|c|c|c|c|c|c|c|}
\hline \multirow{2}{*}{$\begin{array}{l}\text { GLASS } \\
\text { Oxides }\end{array}$} & \multicolumn{2}{|c|}{ ORPLF1 } & \multicolumn{2}{|c|}{ ORPLF2 } & \multicolumn{2}{|c|}{ ORPLF3 } & \multicolumn{2}{|c|}{ ORPLF4 } & \multicolumn{2}{|c|}{ ORPLF5 } & \multicolumn{2}{|c|}{ ORPLF6 } & \multicolumn{2}{|c|}{ ORPLF7 } \\
\hline & Target & Analyzed ${ }^{*}$ & Target & Analyzed* & Target & Analyzed ${ }^{*}$ & Target & Analyzed* & Target & Analyzed* & Target & Analyzed ${ }^{*}$ & Target & Analyzed* \\
\hline $\mathrm{Al}_{2} \mathrm{O}_{3}$ & 10.03 & 9.87 & 9.89 & 9.59 & 9.76 & 9.54 & 8.60 & 8.61 & 9.62 & 9.45 & 8.48 & 8.29 & 8.60 & 8.33 \\
\hline $\mathrm{B}_{2} \mathrm{O}_{3}$ & 9.75 & 10.18 & 9.61 & 10.00 & 9.48 & 9.54 & 9.50 & 9.49 & 9.34 & 8.46 & 9.36 & 8.42 & 9.50 & 8.95 \\
\hline $\mathrm{CaO}$ & 10.00 & 9.81 & 9.86 & 9.88 & 9.72 & 9.82 & 9.72 & 9.69 & 9.58 & 9.83 & 9.58 & 9.87 & 9.72 & 9.87 \\
\hline $\mathrm{Cr}_{2} \mathrm{O}_{3}$ & 0.55 & 0.73 & 0.55 & 0.75 & 0.56 & 0.76 & 0.56 & 0.77 & 0.56 & 0.76 & 0.56 & 0.79 & 0.56 & 0.75 \\
\hline $\mathrm{Fe}_{2} \mathrm{O}_{3}$ & 0.31 & 0.34 & 0.30 & 0.35 & 0.30 & 0.35 & 0.30 & 0.36 & 0.29 & 0.36 & 0.29 & 0.37 & 0.30 & 0.36 \\
\hline $\mathrm{K}_{2} \mathrm{O}$ & 0.41 & 0.38 & 0.45 & 0.43 & 0.50 & 0.45 & 0.50 & 0.44 & 0.54 & 0.49 & 0.54 & 0.51 & 0.50 & 0.48 \\
\hline $\mathrm{Li}_{2} \mathrm{O}$ & 3.75 & 4.10 & 3.70 & 4.07 & 3.65 & 4.03 & 3.50 & 3.82 & 3.59 & 3.92 & 3.45 & 3.81 & 4.35 & 4.75 \\
\hline $\mathrm{MgO}$ & 1.01 & 0.94 & 0.99 & 0.89 & 0.98 & 0.86 & 0.98 & 0.83 & 0.97 & 0.84 & 0.97 & 0.90 & 0.98 & 0.92 \\
\hline $\mathrm{Na}_{2} \mathrm{O}$ & 10.00 & 10.20 & 11.00 & 11.03 & 12.00 & 11.78 & 12.00 & 11.11 & 13.00 & 12.69 & 13.00 & 11.97 & 12.00 & 11.77 \\
\hline $\mathrm{SiO}_{2}$ & 43.35 & 43.50 & 42.74 & 42.79 & 42.14 & 42.52 & 42.14 & 42.75 & 41.54 & 42.05 & 41.54 & 42.14 & 42.14 & 42.15 \\
\hline $\mathrm{SnO}_{2}$ & 0.88 & 1.09 & 0.86 & 1.13 & 0.85 & 1.13 & 0.85 & 1.14 & 0.84 & 0.99 & 0.84 & 0.99 & 0.00 & 0.00 \\
\hline $\mathrm{V}_{2} \mathrm{O}_{5}$ & 1.25 & 1.55 & 1.24 & 1.52 & 1.22 & 1.53 & 2.50 & 3.07 & 1.20 & 1.50 & 2.47 & 3.11 & 2.50 & 3.10 \\
\hline $\mathrm{ZnO}$ & 3.00 & 3.10 & 2.96 & 3.10 & 2.91 & 3.12 & 2.91 & 3.09 & 2.87 & 3.08 & 2.87 & 3.13 & 2.91 & 3.11 \\
\hline $\mathrm{ZrO}_{2}$ & 4.00 & 3.84 & 3.94 & 3.87 & 3.88 & 3.86 & 3.88 & 3.81 & 3.83 & 3.69 & 3.83 & 3.72 & 3.88 & 3.78 \\
\hline $\mathrm{Cl}$ & 0.01 & 0.00 & 0.01 & 0.00 & 0.01 & 0.00 & 0.01 & 0.00 & 0.01 & 0.02 & 0.01 & 0.03 & 0.01 & 0.01 \\
\hline $\mathrm{F}$ & 0.07 & NA & 0.08 & NA & 0.08 & NA & 0.08 & NA & 0.09 & NA & 0.09 & NA & 0.08 & NA \\
\hline $\mathrm{P}_{2} \mathrm{O}_{5}$ & 0.03 & 0.04 & 0.03 & 0.04 & 0.04 & 0.05 & 0.04 & 0.05 & 0.04 & 0.05 & 0.04 & 0.05 & 0.04 & 0.05 \\
\hline $\mathrm{SO}_{3}$ & 1.61 & 0.92 & 1.77 & 1.15 & 1.93 & 0.93 & 1.93 & 1.10 & 2.09 & 1.08 & 2.09 & 1.13 & 1.93 & 1.32 \\
\hline SUM & 100.0 & 100.7 & 100.0 & 100.7 & 100.0 & 100.4 & 100.0 & 100.2 & 100.0 & 99.4 & 100.0 & 99.3 & 100.0 & 99.8 \\
\hline
\end{tabular}

- Analyzed by X-ray fluorescence except for boron and lithium which were measured by DCP

NA - Not analyzed 
Table 2.22. Target and Analyzed Compositions (wt\%) of Fourteen ORPLF Crucible Glasses (continued).

\begin{tabular}{|c|c|c|c|c|c|c|c|c|c|c|c|c|c|c|}
\hline \multirow{2}{*}{$\begin{array}{l}\text { GLASS } \\
\text { Oxides }\end{array}$} & \multicolumn{2}{|c|}{ ORPLF8 } & \multicolumn{2}{|c|}{ ORPLF9 } & \multicolumn{2}{|c|}{ ORPLF10 } & \multicolumn{2}{|c|}{ ORPLF11 } & \multicolumn{2}{|c|}{ ORPLF12 } & \multicolumn{2}{|c|}{ ORPLF13 } & \multicolumn{2}{|c|}{ ORPLF14 } \\
\hline & Target & Analyzed* & Target & Analyzed* & Target & Analyzed* & Target & Analyzed ${ }^{*}$ & Target & Analyzed* & Target & Analyzed* & Target & Analyzed* \\
\hline $\mathrm{Al}_{2} \mathrm{O}_{3}$ & 8.60 & 8.28 & 7.60 & 7.32 & 8.60 & 8.29 & 8.60 & 8.33 & 8.60 & 8.10 & 8.60 & 7.97 & 8.60 & 8.13 \\
\hline $\mathrm{B}_{2} \mathrm{O}_{3}$ & 8.85 & 8.66 & 8.85 & 8.52 & 9.50 & 8.85 & 9.50 & 9.02 & 9.50 & 9.05 & 9.50 & 9.20 & 9.50 & 9.07 \\
\hline $\mathrm{CaO}$ & 9.72 & 9.98 & 9.72 & 9.78 & 10.57 & 10.66 & 9.72 & 9.80 & 9.72 & 10.21 & 10.57 & 11.54 & 10.57 & 11.07 \\
\hline $\mathrm{Cr}_{2} \mathrm{O}_{3}$ & 0.56 & 0.79 & 0.56 & 0.78 & 0.56 & 0.75 & 0.56 & 0.76 & 0.56 & 0.71 & 0.56 & 0.75 & 0.56 & 0.73 \\
\hline $\mathrm{Fe}_{2} \mathrm{O}_{3}$ & 0.30 & 0.36 & 0.30 & 0.36 & 0.30 & 0.35 & 0.30 & 0.36 & 0.30 & 0.33 & 0.00 & 0.00 & 0.00 & 0.00 \\
\hline $\mathrm{K}_{2} \mathrm{O}$ & 0.50 & 0.50 & 0.50 & 0.48 & 0.50 & 0.47 & 0.50 & 0.47 & 0.50 & 0.51 & 0.50 & 0.52 & 0.50 & 0.53 \\
\hline $\mathrm{Li}_{2} \mathrm{O}$ & 5.00 & 5.16 & 3.50 & 3.78 & 3.50 & 3.81 & 3.50 & 3.77 & 3.50 & 3.73 & 3.50 & 3.77 & 3.71 & 3.89 \\
\hline $\mathrm{MgO}$ & 0.98 & 0.85 & 0.98 & 0.88 & 0.98 & 0.87 & 0.98 & 0.90 & 0.98 & 0.86 & 0.00 & 0.00 & 0.00 & 0.00 \\
\hline $\mathrm{Na}_{2} \mathrm{O}$ & 12.00 & 11.44 & 12.00 & 11.87 & 12.00 & 11.88 & 12.00 & 11.45 & 12.00 & 12.49 & 12.00 & 11.28 & 12.00 & 11.93 \\
\hline $\mathrm{SiO}_{2}$ & 42.14 & 42.18 & 41.82 & 41.42 & 42.14 & 42.54 & 42.14 & 42.47 & 42.14 & 41.39 & 42.14 & 41.27 & 42.14 & 41.36 \\
\hline $\mathrm{SnO}_{2}$ & 0.00 & 0.01 & 0.85 & 1.04 & 0.00 & 0.01 & 0.60 & 0.80 & 0.00 & 0.01 & 1.00 & 1.19 & 1.00 & 1.23 \\
\hline $\mathrm{V}_{2} \mathrm{O}_{5}$ & 2.50 & 3.12 & 2.50 & 3.10 & 2.50 & 3.02 & 2.75 & 3.39 & 2.75 & 2.99 & 2.72 & 3.18 & 2.50 & 2.80 \\
\hline $\mathrm{ZnO}$ & 2.91 & 3.15 & 2.91 & 3.12 & 2.91 & 3.02 & 2.91 & 3.08 & 2.91 & 2.91 & 2.91 & 3.15 & 2.91 & 2.97 \\
\hline $\mathrm{ZrO}_{2}$ & 3.88 & 3.82 & 3.88 & 3.78 & 3.88 & 3.73 & 3.88 & 3.79 & 4.49 & 4.17 & 3.95 & 3.92 & 3.95 & 3.82 \\
\hline $\mathrm{Cl}$ & 0.01 & 0.01 & 0.01 & 0.01 & 0.01 & 0.01 & 0.01 & 0.02 & 0.01 & 0.02 & 0.01 & 0.01 & 0.01 & 0.01 \\
\hline $\mathrm{F}$ & 0.08 & NA & 0.08 & NA & 0.08 & NA & 0.09 & NA & 0.09 & NA & 0.08 & NA & 0.08 & NA \\
\hline $\mathrm{P}_{2} \mathrm{O}_{5}$ & 0.04 & 0.05 & 2.00 & 2.10 & 0.04 & 0.04 & 0.04 & 0.08 & 0.04 & 0.05 & 0.04 & 0.05 & 0.04 & 0.05 \\
\hline $\mathrm{SO}_{3}$ & 1.93 & 1.47 & 1.93 & 1.43 & 1.93 & 1.24 & 1.93 & 1.16 & 1.93 & 2.10 & 1.93 & 1.97 & 1.93 & 1.96 \\
\hline SUM & 100.0 & 99.9 & 100.0 & 99.8 & 100.0 & 99.6 & 100.0 & 99.7 & 100.0 & 99.7 & 100.0 & 99.9 & 100.0 & 99.6 \\
\hline
\end{tabular}

- Analyzed by X-ray fluorescence except for boron and lithium which was measured by DCP

NA - Not analyzed 
Table 2.23. Descriptions of Fourteen As-Melted and Heat Treated ORPLF Crucible Glasses.

\begin{tabular}{|c|c|c|}
\hline Glass ID & As-melted glass & $\begin{array}{c}\text { Glass remelted at } 1200^{\circ} \mathrm{C} \text { for } 1 \text { hour, heat treated for } 20 \\
\text { hours at } 950^{\circ} \mathrm{C} \text {, and quenched. }\end{array}$ \\
\hline ORPLF1 & Mostly clear glass. $~ 0.2$ vol\% tiny Cr oxide crystals & Mostly clear glass. $\sim 0.2$ vol\% Cr oxide crystals $+\mathrm{Zn}$ and $\mathrm{Sn}$ \\
\hline ORPLF2 & Mostly clear glass. $~ 0.1$ vol\% tiny Cr oxide crystals & Mostly clear glass. $\sim 0.2$ vol\% Cr oxide crystals $+\mathrm{Zn}$ and Sn \\
\hline ORPLF3 & Mostly clear glass. 0.2 vol\% tiny Cr oxide crystals & Mostly clear glass. $\sim 0.3$ vol\% Cr oxide crystals $+\mathrm{Zn}$ and Sn \\
\hline ORPLF4 & Mostly clear glass. 0.1 vol\% tiny Cr oxide crystals & Mostly clear glass. $<0.1$ vol\% Cr oxide crystals $+\mathrm{Zn}$ and $\mathrm{Sn}$ \\
\hline ORPLF5 & Mostly clear glass. $0.1-0.2$ vol\% Cr-Zn oxide crystals & Clear glass. $<<0.1$ vol\% Cr-Zn oxide crystals \\
\hline ORPLF6 & Mostly clear glass. 0.1-0.2 vol\% Cr-Zn oxide crystals & Clear glass. $<<0.1$ vol\% Cr-Zn oxide crystals \\
\hline ORPLF7 & Mostly clear glass. $~ 0.2$ vol\% Cr-Zn oxide crystals & Mostly clear glass. $\sim 0.1$ vol\% Cr-Zn oxide crystals \\
\hline ORPLF8 & Mostly clear glass. $\sim 0.2$ vol\% Cr-Zn oxide crystals & Mostly clear glass. $<0.1$ vol\% Cr-Zn oxide crystals \\
\hline ORPLF9 & Clear glass. $<<0.1$ vol\% Cr-Zn oxide crystals & Mostly clear glass. $<0.1$ vol\% Cr-Zn oxide crystals \\
\hline ORPLF10 & Mostly clear glass. $\sim 0.3$ vol\% Cr-Zn oxide crystals & 0.1-0.2 vol\% Cr-Zn oxide crystals \\
\hline ORPLF11 & Mostly clear glass. $~ 0.1$ vol\% Cr-Zn oxide crystals & Clear glass. $<<0.1 \%$ Cr-Zn oxide crystals \\
\hline ORPLF12 & Mostly clear glass. $\sim 0.2$ vol\% Cr-Zn oxide crystals & $\sim 0.1-0.2$ vol.\% Cr-Zn oxide crystals \\
\hline ORPLF13 & Clear glass. $<<0.1$ vol\% Cr-Zn oxide crystals & Clear glass. Few platinum particles and Cr-Zn crystals \\
\hline ORPLF14 & Clear glass. $<<0.1$ vol\% Cr-Zn oxide crystals & Mostly clear glass. $<0.1$ vol\% Cr-Zn oxide crystals \\
\hline
\end{tabular}


Table 2.24. Measured Sulfate Solubilities in Twelve ORPLF Crucible Glasses.

\begin{tabular}{|c|c|c|}
\hline \multirow{3}{*}{ Sample ID } & \multicolumn{2}{|c|}{$\mathrm{SO}_{3}$ Content (wt\%) } \\
\hline & \multicolumn{2}{|c|}{ Batch Saturation } \\
\hline & As-Melted & After Acid Wash \\
\hline ORPLF1S4 & 1.39 & 1.26 \\
\hline ORPLF2S4 & 1.42 & 1.23 \\
\hline ORPLF3S4 & 1.64 & 1.24 \\
\hline ORPLF4S4 & 1.73 & 1.32 \\
\hline ORPLF5S4 & 1.49 & 1.19 \\
\hline ORPLF6S4 & 1.77 & 1.28 \\
\hline ORPLF7S4 & 1.86 & 1.44 \\
\hline ORPLF8S4 & 1.85 & 1.45 \\
\hline ORPLF9S4 & 1.66 & 1.40 \\
\hline ORPLF10S4 & 1.79 & 1.41 \\
\hline ORPLF11S4 & 1.71 & 1.35 \\
\hline ORPLF12S4 & 1.70 & 1.33 \\
\hline ORPLF13S4 & 1.61 & 1.36 \\
\hline ORPLF14S4 & 1.61 & 1.41 \\
\hline
\end{tabular}


Table 2.25. Results of 7-day PCT (at $90^{\circ} \mathrm{C}$ ) and VHT (at $200^{\circ} \mathrm{C}$ for 24 Days) for Fourteen ORPLF Crucible Glasses.

\begin{tabular}{|c|c|c|c|c|c|c|c|c|c|c|c|c|c|c|}
\hline Glass ID & ORPLF1 & ORPLF2 & ORPLF3 & ORPLF4 & ORPLF5 & ORPLF6 & ORPLF7 & ORPLF8 & ORPLF9 & ORPLF10 & ORPLF11 & ORPLF12 & ORPLF13 & ORPLF14 \\
\hline \multicolumn{15}{|c|}{ 7-Day PCT, Stainless Steel Vessel; S/V=2000m ${ }^{-1} \quad(\mathrm{ppm})$} \\
\hline B & 4.71 & 4.81 & 8.33 & 8.96 & 9.15 & 9.53 & 9.78 & 10.21 & 17.04 & 10.52 & 9.60 & 10.40 & 5.98 & 7.66 \\
\hline $\mathrm{Li}$ & 7.40 & 9.13 & 9.41 & 7.61 & 13.13 & 10.03 & 12.75 & 15.36 & 12.76 & 11.32 & 9.15 & 9.61 & 7.85 & 9.30 \\
\hline $\mathrm{Na}$ & 38.53 & 53.33 & 54.73 & 43.47 & 114.60 & 66.50 & 63.48 & 57.61 & 65.59 & 81.49 & 51.49 & 54.77 & 44.61 & 49.37 \\
\hline $\mathrm{Si}$ & 22.64 & 24.56 & 27.02 & 31.58 & 24.22 & 29.38 & 32.28 & 40.77 & 50.31 & 30.13 & 33.48 & 35.28 & 29.10 & 35.27 \\
\hline \multicolumn{15}{|c|}{ Normalized Concentrations (g/L) } \\
\hline $\mathrm{B}$ & 0.16 & 0.16 & 0.28 & 0.30 & 0.32 & 0.33 & 0.33 & 0.37 & 0.62 & 0.36 & 0.33 & 0.35 & 0.20 & 0.26 \\
\hline $\mathrm{Li}$ & 0.42 & 0.53 & 0.56 & 0.47 & 0.79 & 0.63 & 0.63 & 0.66 & 0.78 & 0.70 & 0.56 & 0.59 & 0.48 & 0.54 \\
\hline $\mathrm{Na}$ & 0.52 & 0.65 & 0.61 & 0.49 & 1.19 & 0.69 & 0.71 & 0.65 & 0.74 & 0.92 & 0.58 & 0.62 & 0.50 & 0.55 \\
\hline Si & 0.11 & 0.12 & 0.14 & 0.16 & 0.12 & 0.15 & 0.16 & 0.21 & 0.26 & 0.15 & 0.17 & 0.18 & 0.15 & 0.18 \\
\hline $\mathrm{pH}$ & 10.75 & 10.85 & 10.91 & 10.99 & 10.88 & 10.98 & 11.09 & 11.28 & 10.98 & 10.89 & 10.98 & 10.99 & 11.02 & 11.05 \\
\hline \multicolumn{15}{|c|}{ 7-Day PCT Normalized Mass Loss $\left(\mathrm{g} / \mathrm{m}^{2}\right)$} \\
\hline B & 0.08 & 0.08 & 0.14 & 0.15 & 0.16 & 0.16 & 0.17 & 0.19 & 0.31 & 0.18 & 0.16 & 0.18 & 0.10 & 0.13 \\
\hline $\mathrm{Li}$ & 0.21 & 0.27 & 0.28 & 0.23 & 0.39 & 0.31 & 0.32 & 0.33 & 0.39 & 0.35 & 0.28 & 0.30 & 0.24 & 0.27 \\
\hline $\mathrm{Na}$ & 0.26 & 0.33 & 0.31 & 0.24 & 0.59 & 0.34 & 0.36 & 0.32 & 0.37 & 0.46 & 0.29 & 0.31 & 0.25 & 0.28 \\
\hline $\mathrm{Si}$ & 0.06 & 0.06 & 0.07 & 0.08 & 0.06 & 0.08 & 0.08 & 0.10 & 0.13 & 0.08 & 0.08 & 0.09 & 0.07 & 0.09 \\
\hline \multicolumn{15}{|c|}{ 7-Day PCT Normalized Loss Rate (g/m²/d) } \\
\hline $\mathrm{B}$ & 0.01 & 0.01 & 0.02 & 0.02 & 0.02 & 0.02 & 0.02 & 0.03 & 0.04 & 0.03 & 0.02 & 0.03 & 0.01 & 0.02 \\
\hline $\mathrm{Li}$ & 0.03 & 0.04 & 0.04 & 0.03 & 0.06 & 0.04 & 0.05 & 0.05 & 0.06 & 0.05 & 0.04 & 0.04 & 0.03 & 0.04 \\
\hline $\mathrm{Na}$ & 0.04 & 0.05 & 0.04 & 0.03 & 0.08 & 0.05 & 0.05 & 0.05 & 0.05 & 0.07 & 0.04 & 0.04 & 0.04 & 0.04 \\
\hline $\mathrm{Si}$ & 0.01 & 0.01 & 0.01 & 0.01 & 0.01 & 0.01 & 0.01 & 0.01 & 0.02 & 0.01 & 0.01 & 0.01 & 0.01 & 0.01 \\
\hline \multicolumn{15}{|c|}{ VHT Alteration ( 24 days at $200^{\circ} \mathrm{C}$ ) } \\
\hline $\begin{array}{c}\text { Alteration } \\
\text { Depth }(\mu \mathrm{m}) \\
\end{array}$ & 43 & 168 & 131 & 193 & $\begin{array}{c}75 \text { to } \\
200 \\
\end{array}$ & 151 & 164 & 95 & 273 & 122 & 236 & 222 & 108 & 94 \\
\hline $\begin{array}{c}\text { Alteration Rate } \\
\left(\mathrm{g} / \mathrm{m}^{2} / \text { day }\right)^{*}\end{array}$ & 5 & 19 & 14 & 21 & 8 to 22 & 17 & 18 & 10 & 30 & 13 & 26 & 25 & 12 & 10 \\
\hline
\end{tabular}

\footnotetext{
* Alteration rates calculated using estimated density of $2.65 \mathrm{~g} / \mathrm{cc}$
} 
Table 2.26. Viscosities and Electrical Conductivities of Eleven ORPLF Crucible Glasses.

\begin{tabular}{|c|c|c|c|c|c|c|c|c|c|c|c|}
\hline $\begin{array}{c}\text { Glass } \\
\text { ID }\end{array}$ & ORPLF1 & ORPLF2 & ORPLF3 & ORPLF4 & ORPLF7 & ORPLF8 & ORPLF9 & ORPLF10 & ORPLF12 & ORPLF13 & ORPLF14 \\
\hline \multicolumn{12}{|c|}{ Viscosity (poise) } \\
\hline $900^{\circ} \mathrm{C}$ & 1076 & 833 & 776 & 660 & 401 & 301 & 743 & 537 & 601 & 637 & 647 \\
\hline $950^{\circ} \mathrm{C}$ & 435 & 362 & 339 & 287 & 177 & 145 & 302 & 240 & 269 & 270 & 268 \\
\hline $1000^{\circ} \mathrm{C}$ & 206 & 177 & 166 & 141 & 90 & 77 & 144 & 120 & 134 & 132 & 129 \\
\hline $1050^{\circ} \mathrm{C}$ & 109 & 95 & 90 & 76 & 51 & 44 & 77 & 66 & 73 & 71 & 70 \\
\hline $1100^{\circ} \mathrm{C}$ & 64 & 55 & 52 & 44 & 32 & 27 & 45 & 39 & 43 & 42 & 41 \\
\hline $1150^{\circ} \mathrm{C}$ & 40 & 34 & 33 & 27 & 21 & 18 & 29 & 24 & 27 & 26 & 26 \\
\hline $1200^{\circ} \mathrm{C}$ & 27 & 22 & 21 & 18 & 14 & 12 & 19 & 16 & 18 & 18 & 18 \\
\hline $1250^{\circ} \mathrm{C}$ & 19 & 15 & 15 & 12 & 10 & 9 & 14 & 11 & 12 & 12 & 13 \\
\hline \multicolumn{12}{|c|}{ Electrical Conductivity (S/cm) } \\
\hline $900^{\circ} \mathrm{C}$ & 0.062 & 0.074 & 0.074 & 0.082 & 0.106 & 0.135 & 0.093 & 0.091 & 0.089 & 0.085 & 0.112 \\
\hline $950^{\circ} \mathrm{C}$ & 0.086 & 0.100 & 0.100 & 0.111 & 0.157 & 0.178 & 0.126 & 0.121 & 0.122 & 0.120 & 0.153 \\
\hline $1000^{\circ} \mathrm{C}$ & 0.115 & 0.131 & 0.131 & 0.146 & 0.216 & 0.229 & 0.167 & 0.158 & 0.161 & 0.162 & 0.199 \\
\hline $1050^{\circ} \mathrm{C}$ & 0.152 & 0.170 & 0.170 & 0.189 & 0.280 & 0.290 & 0.215 & 0.202 & 0.210 & 0.210 & 0.251 \\
\hline $1100^{\circ} \mathrm{C}$ & 0.196 & 0.216 & 0.216 & 0.239 & 0.349 & 0.361 & 0.273 & 0.254 & 0.267 & 0.264 & 0.308 \\
\hline $1150^{\circ} \mathrm{C}$ & 0.249 & 0.269 & 0.269 & 0.299 & 0.420 & 0.442 & 0.341 & 0.314 & 0.335 & 0.324 & 0.369 \\
\hline $1200^{\circ} \mathrm{C}$ & 0.311 & 0.330 & 0.330 & 0.367 & 0.492 & 0.534 & 0.419 & 0.382 & 0.414 & 0.388 & 0.432 \\
\hline $1250^{\circ} \mathrm{C}$ & 0.382 & 0.401 & 0.401 & 0.445 & 0.565 & 0.637 & 0.508 & 0.459 & 0.504 & 0.456 & 0.499 \\
\hline
\end{tabular}


The Catholic University of America Vitreous State Laboratory

Table 2.27. Results of K-3 Corrosion Testing for Ten ORPLF Crucible Glasses.

\begin{tabular}{|c|c|c|c|}
\hline Glass ID & $\begin{array}{c}\text { Neck loss } \\
\text { (inches) }\end{array}$ & $\begin{array}{c}\text { Depth of altered } \\
\text { zone (inches) }\end{array}$ & $\begin{array}{c}\text { Half-down loss } \\
\text { (inches) }\end{array}$ \\
\hline ORPLF4 & 0.009 & 0.030 & 0 \\
\hline ORPLF4-Repeat & $\begin{array}{c}0.003 \\
\mathrm{Al}_{2} \mathrm{O}_{3} \\
\text { contamination }\end{array}$ & 0.025 & $\begin{array}{c}\text { Coupon expanded }- \\
\text { no measurable loss }\end{array}$ \\
\hline ORPLF7 & 0.010 & 0.029 & 0.003 \\
\hline ORPLF7-Repeat & 0.020 & 0.030 & 0.002 \\
\hline ORPLF8 & 0.018 & 0.031 & $\begin{array}{c}\text { Coupon expanded }- \\
\text { no measurable loss }\end{array}$ \\
\hline ORPLF9 & 0.004 & 0.025 & 0 \\
\hline ORPLF10 & 0.009 & 0.029 & 0 \\
\hline ORPLF10-Repeat & 0.005 & 0.027 & $\begin{array}{c}\text { Coupon expanded - } \\
\text { no measurable loss }\end{array}$ \\
\hline ORPLF13 & 0.013 & 0.030 & 0.0005 \\
\hline ORPLF14 & 0.017 & 0.030 & $\begin{array}{c}\text { Coupon expanded - } \\
\text { no measurable loss }\end{array}$ \\
\hline
\end{tabular}


Table 2.28. Summary of Test Results for Selected ORPLF Glass Formulation ORPLF7 and Comparison to ILAW Requirements.

\begin{tabular}{|c|c|c|}
\hline Test & Requirement $[53,54]$ & $\begin{array}{l}\text { Test Result for } \\
\text { ORPLF7 }\end{array}$ \\
\hline Density of glass & $<3.7 \mathrm{~g} / \mathrm{cc}$ & $2.62 \mathrm{~g} / \mathrm{cc}$ \\
\hline Crystalline Phase & Phase identification & $\begin{array}{l}\text { Clear homogeneous glass } \\
\text { with less than } 0.1 \text { vol\% crystals after } \\
\text { heat treatment at } 850^{\circ} \mathrm{C} \text { for } 20 \text { hours }\end{array}$ \\
\hline Liquidus & $<950^{\circ} \mathrm{C}$ & $<950^{\circ} \mathrm{C}$ \\
\hline Centerline Canister Cooling & Phase identification & Not measured \\
\hline PCT B $\quad\left(g / m^{2}\right)$ & $<2.0 \mathrm{~g} / \mathrm{m}^{2}$ & $0.17 \mathrm{~g} / \mathrm{m}^{2}$ \\
\hline PCT Li (g/m²) & $<2.0 \mathrm{~g} / \mathrm{m}^{2}$ & $0.32 \mathrm{~g} / \mathrm{m}^{2}$ \\
\hline $\operatorname{PCT~Na}\left(\mathrm{g} / \mathrm{m}^{2}\right)$ & $<2.0 \mathrm{~g} / \mathrm{m}^{2}$ & $0.36 \mathrm{~g} / \mathrm{m}^{2}$ \\
\hline PCT Si $\left(g / m^{2}\right)$ & $<2.0 \mathrm{~g} / \mathrm{m}^{2}$ & $0.08 \mathrm{~g} / \mathrm{m}^{2}$ \\
\hline VHT at $200^{\circ} \mathrm{C}\left(\mathrm{g} / \mathrm{m}^{2} /\right.$ day $)$ & $<50 \mathrm{~g} / \mathrm{m}^{2} /$ day & $18 \mathrm{~g} / \mathrm{m}^{2} /$ day \\
\hline Viscosity (poise) at $1100^{\circ} \mathrm{C}$ & 10 to $150 \mathrm{P}$ & $32 \mathrm{P}$ \\
\hline Conductivity $(\mathrm{S} / \mathrm{cm})$ at $1100^{\circ} \mathrm{C}$ & 0.2 to $0.7 \mathrm{~S} / \mathrm{cm}$ & $0.349 \mathrm{~S} / \mathrm{cm}$ \\
\hline $\mathrm{T}_{\mathrm{G}}\left({ }^{\circ} \mathrm{C}\right)$ & Report for modeling & Not measured \\
\hline
\end{tabular}

*Density measured for melter glass Z10-G-153B of the ORPLF7 composition 
The Catholic University of America Vitreous State Laboratory

Table 2.29. Oxide Composition of AZ-102 Simulant and ORPLF7 Glass Composition Used in Melter Tests (wt\%).

\begin{tabular}{|c|c|c|c|}
\hline Component & AZ-102 waste contribution & $\begin{array}{c}\text { Glass former } \\
\text { additives }\end{array}$ & $\begin{array}{c}\text { ORPLF7 } \\
\text { (for AZ-102) }\end{array}$ \\
\hline Loading & $14.3 \%$ & $85.7 \%$ & - \\
\hline $\mathrm{Al}_{2} \mathrm{O}_{3}$ & 0.04 & 8.61 & 8.65 \\
\hline $\mathrm{B}_{2} \mathrm{O}_{3}$ & - & 9.54 & 9.54 \\
\hline $\mathrm{CaO}$ & - & 9.78 & 9.78 \\
\hline $\mathrm{Cr}_{2} \mathrm{O}_{3}$ & 0.12 & 0.44 & 0.56 \\
\hline $\mathrm{Fe}_{2} \mathrm{O}_{3}$ & - & 0.23 & 0.23 \\
\hline $\mathrm{K}_{2} \mathrm{O}$ & 0.50 & - & 0.43 \\
\hline $\mathrm{Li}_{2} \mathrm{O}$ & - & 4.37 & 4.37 \\
\hline $\mathrm{MgO}^{\mathrm{Na} O} \mathrm{O}^{(\mathrm{a})}$ & - & 0.98 & 0.98 \\
\hline $\mathrm{SiO}_{2}$ & $10.45+1.16^{(1)}+0.39^{(2)}$ & - & 12.00 \\
\hline $\mathrm{V}_{2} \mathrm{O}_{5}$ & 0.06 & 42.44 & 42.50 \\
\hline $\mathrm{ZnO}_{\mathrm{ZnO}}$ & - & 2.50 & 2.50 \\
\hline $\mathrm{Zl}_{2}$ & - & 2.92 & 2.92 \\
\hline $\mathrm{F}$ & - & 3.92 & 3.92 \\
\hline $\mathrm{P}_{2} \mathrm{O}_{5}$ & 0.01 & - & 0.01 \\
\hline $\mathrm{SO}_{3}{ }^{(b)}$ & 0.08 & - & 0.07 \\
\hline $\mathrm{SUM}$ & 0.04 & - & 0.03 \\
\hline $1.500^{(1)}$ & 14.35 & 85.65 & 1.50 \\
\hline & 1400.0 \\
\hline
\end{tabular}

(a) Simulant was ordered at a concentration of $10.45 \mathrm{wt} \% \mathrm{Na}_{2} \mathrm{O}$ and modified before each melter test with (1) $\mathrm{Na}_{2} \mathrm{SO}_{4}$ and (2) $\mathrm{NaOH}$ additions to obtain $12.00 \mathrm{wt} \% \mathrm{Na}_{2} \mathrm{O}$ in the glass. (b) Concentration of $\mathrm{SO}_{3}$ was increased in steps during the melter tests.

- Empty data field 
Table 2.30a. Glass Former Additives for 1 Liter of LAW AZ-102 Simulant (5.5 M Na) and Corresponding Melter Feed Properties.

\begin{tabular}{|c|c|}
\hline Additives Source & Feed ORPLF7 \\
\hline Additives in Glass (wt\%) & 85.7 \\
\hline Kyanite $\left(\mathrm{Al}_{2} \mathrm{SiO}_{5}\right) 325$ Mesh (Kyanite Mining) (g) & 208.79 \\
\hline $\mathrm{H}_{3} \mathrm{BO}_{3}$ (US Borax - Technical Granular) (g) & 239.27 \\
\hline Wollanstonite NYAD 325 Mesh (NYCO Minerals) (g) & 303.76 \\
\hline $\mathrm{Cr}_{2} \mathrm{O}_{3}$ oxide & 6.19 \\
\hline $\mathrm{Li}_{2} \mathrm{CO}_{3}$ (Chemetall Foote Co, Tech Grade) & 154.48 \\
\hline Olivine $\left(\mathrm{Mg}_{2} \mathrm{SiO}_{4}\right) 325 \mathrm{Mesh}(\# 180$ Unimin) (g) & 24.05 \\
\hline $\mathrm{SiO}_{2}$ (Sil-co-Sil 75 US Silica) (g) & 312.34 \\
\hline $\mathrm{V}_{2} \mathrm{O}_{5}-$ Pulva Ground - Stratcor & 35.53 \\
\hline ZnO (KADOX - 920 Zinc Corp. of America) (g) & 41.33 \\
\hline Zircon $\mathrm{ZrSiO}_{4}$ (Flour) Mesh 325 (AM. Mineral) (g) & 83.12 \\
\hline $\mathrm{Na}_{2} \mathrm{SO}_{4}$ & Variable - Table 2.30b \\
\hline Addition of Sucrose as Reductant (g) & 3.46 \\
\hline Simulant Weight for 1 liter (g) & 1177 \\
\hline Sum of Additives (g) & 1412 \\
\hline Sum of Complete Batch (g) & 2589 \\
\hline Target Final Volume (l) & 1.53 \\
\hline Estimated Density $(\mathrm{g} / \mathrm{ml})$ & 1.7 \\
\hline Target Glass Produced (g) & 1420 \\
\hline Target Weight \% Additives in Slurry & 55 \\
\hline Target Glass Yield (g/kg of Feed) & 549 \\
\hline Target Glass Yield (g/l of Feed) & 922 \\
\hline Target Total Solids ( $\mathrm{g} / \mathrm{l}$ of Feed) & 1008 \\
\hline Target Additives (g/l of Feed) & 917 \\
\hline
\end{tabular}

*Preliminary feed test was done with a 5M Na-simulant (density of feed $=1.64$ ) but rheology indicated a low yield stress of $2.7 \mathrm{~Pa}$ ) and a $10 \%$ increase in concenration was selected for the melter test. See

Table 2.30b. $\mathrm{NaOH}$ and $\mathrm{Na}_{2} \mathrm{SO}_{4}$ Additions Required to Obtain $12 \mathrm{wt} \% \mathrm{Na}_{2} \mathrm{O}$ and Various $\mathrm{SO}_{3}$ Concentrations in the ORPLF7 Glass.

\begin{tabular}{|c|c|c|}
\hline $\begin{array}{c}\text { Final } \\
\mathrm{SO}_{3}(\mathrm{wt} \%)\end{array}$ & $\begin{array}{c}\mathrm{NaOH} \text { needed } \\
\text { per kg of feed } \\
\text { (grams) }\end{array}$ & $\begin{array}{c}\mathrm{Na}_{2} \mathrm{SO}_{4} \text { needed } \\
\text { per kg of feed } \\
\text { (grams) }\end{array}$ \\
\hline 0.00 & 22.3 & 0 \\
\hline 1.00 & 11.15 & 10.02 \\
\hline 1.10 & 10.03 & 11.03 \\
\hline 1.20 & 8.92 & 12.03 \\
\hline 1.30 & 7.80 & 13.03 \\
\hline 1.40 & 6.69 & 14.03 \\
\hline 1.50 & 5.57 & 15.04 \\
\hline 1.60 & 4.46 & 16.04 \\
\hline 1.70 & 3.34 & 17.04 \\
\hline
\end{tabular}


Table 2.31. LAW Sub-Envelope A2 (AP-101) Waste Simulant Recipe at 8.45 Molar Sodium.

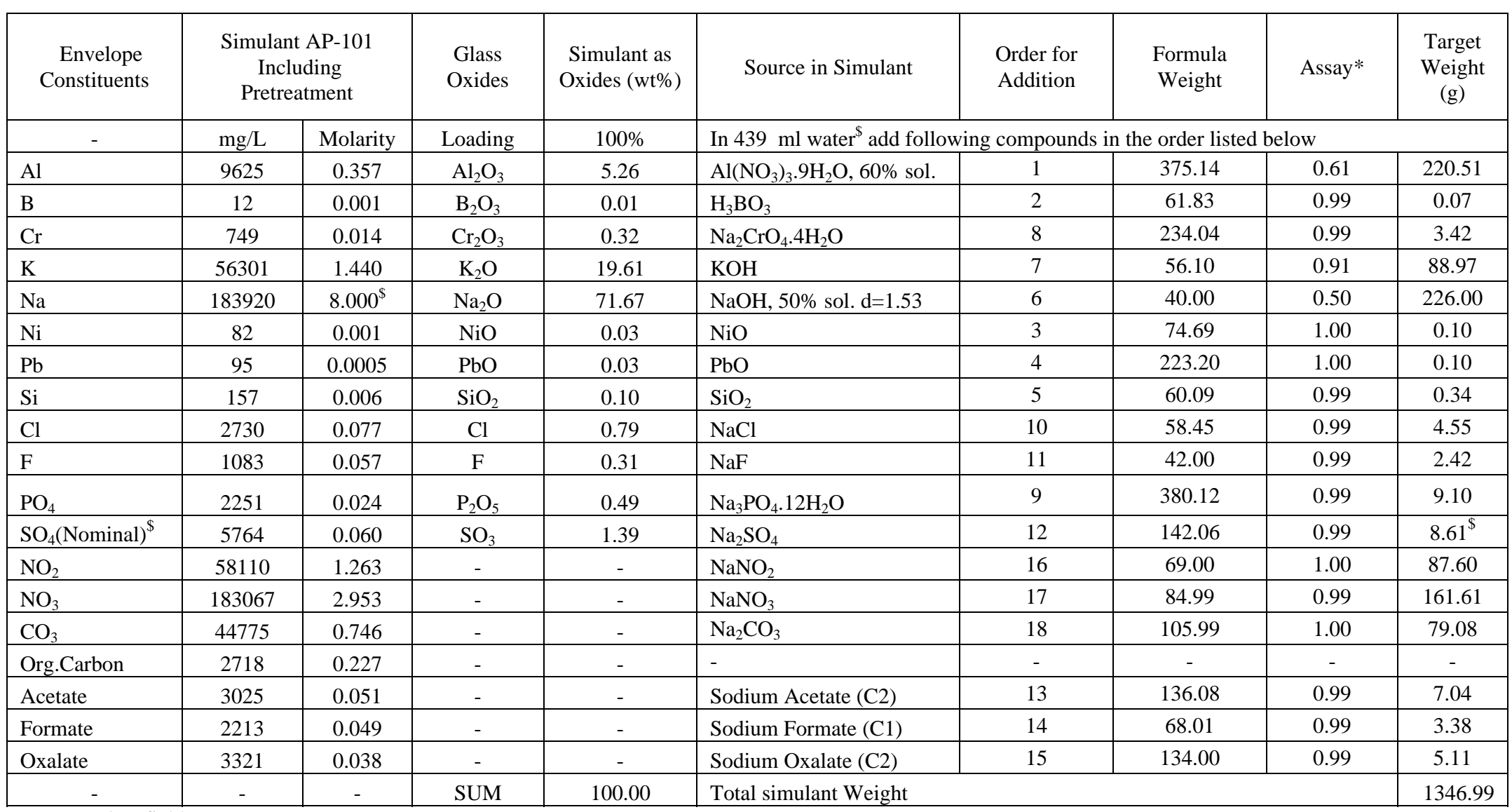

"-" Empty data field.

Assay refers to the purity of the raw material as specified by the vendor.

$\$ \mathrm{SO}_{3}$ content varied during each run, as given in Table 2.40b. The value given here corresponds to the nominal. 
Table 2.32. Target and Analyzed Compositions (wt \%) of Twelve ORPLG Crucible Glasses.

\begin{tabular}{|c|c|c|c|c|c|c|c|c|c|c|c|c|}
\hline GLASS & \multicolumn{2}{|c|}{ ORPLG1 } & \multicolumn{2}{|c|}{ ORPLG2 } & \multicolumn{2}{|c|}{ ORPLG3 } & \multicolumn{2}{|c|}{ ORPLG4 } & \multicolumn{2}{|c|}{ ORPLG5 } & \multicolumn{2}{|c|}{ ORPLG6 } \\
\hline Oxides & Target & Analyzed* & Target & Analyzed* & Target & Analyzed* & Target & Analyzed* & Target & Analyzed* & Target & Analyzed \\
\hline $\mathrm{Al}_{2} \mathrm{O}_{3}$ & 10.04 & 9.86 & 9.99 & 9.63 & 9.95 & 9.64 & 9.95 & 9.67 & 9.95 & 9.63 & 6.77 & 6.59 \\
\hline $\mathrm{B}_{2} \mathrm{O}_{3}$ & 8.90 & 9.67 & 8.82 & 9.57 & 8.74 & 9.32 & 8.74 & 9.46 & 8.74 & 9.22 & 8.70 & 9.46 \\
\hline $\mathrm{CaO}$ & 2.23 & 2.20 & 2.20 & 2.33 & 2.18 & 2.30 & 2.18 & 2.29 & 2.77 & 2.85 & 2.75 & 2.97 \\
\hline $\mathrm{Cr}_{2} \mathrm{O}_{3}$ & 0.60 & 0.70 & 0.60 & 0.72 & 0.60 & 0.73 & 0.60 & 0.73 & 0.60 & 0.73 & 0.60 & 0.75 \\
\hline $\mathrm{Fe}_{2} \mathrm{O}_{3}$ & 0.30 & 0.31 & 0.29 & 0.31 & 0.29 & 0.32 & 0.29 & 0.31 & 0.00 & 0.00 & 0.29 & 0.32 \\
\hline $\mathrm{K}_{2} \mathrm{O}$ & 5.06 & 4.83 & 5.20 & 5.13 & 5.34 & 5.38 & 5.34 & 5.31 & 5.34 & 5.28 & 5.40 & 5.33 \\
\hline $\mathrm{MgO}$ & 0.96 & 0.85 & 0.96 & 0.80 & 0.95 & 0.83 & 0.95 & 0.91 & 0.00 & 0.00 & 0.98 & 0.81 \\
\hline $\mathrm{Na}_{2} \mathrm{O}$ & 18.50 & 18.74 & 19.00 & 18.81 & 19.50 & 18.66 & 19.50 & 19.42 & 19.50 & 19.23 & 19.75 & 19.15 \\
\hline $\mathrm{NiO}$ & 0.01 & 0.02 & 0.01 & 0.01 & 0.01 & 0.01 & 0.01 & 0.01 & 0.01 & 0.01 & 0.01 & 0.01 \\
\hline $\mathrm{PbO}$ & 0.01 & 0.03 & 0.01 & 0.03 & 0.01 & 0.02 & 0.01 & 0.03 & 0.01 & 0.02 & 0.01 & 0.03 \\
\hline $\mathrm{SiO}_{2}$ & 41.27 & 41.73 & 40.89 & 40.82 & 40.50 & 40.80 & 40.50 & 40.88 & 40.79 & 40.96 & 41.75 & 41.44 \\
\hline $\mathrm{SnO}_{2}$ & 2.97 & 3.25 & 2.94 & 3.42 & 2.91 & 3.47 & 4.80 & 4.70 & 2.91 & 3.23 & 2.90 & 3.42 \\
\hline $\mathrm{ZnO}$ & 2.45 & 2.34 & 2.43 & 2.48 & 2.40 & 2.45 & 2.40 & 2.40 & 2.77 & 2.77 & 3.48 & 3.65 \\
\hline $\mathrm{ZrO}_{2}$ & 5.93 & 5.25 & 5.88 & 5.64 & 5.82 & 5.55 & 3.93 & 3.52 & 5.82 & 5.48 & 5.80 & 5.71 \\
\hline $\mathrm{Cl}$ & 0.20 & 0.21 & 0.21 & 0.22 & 0.21 & 0.23 & 0.21 & 0.23 & 0.21 & 0.21 & 0.22 & 0.23 \\
\hline $\mathrm{F}$ & 0.08 & NA & 0.08 & NA & 0.08 & NA & 0.08 & NA & 0.08 & NA & 0.09 & NA \\
\hline $\mathrm{P}_{2} \mathrm{O}_{5}$ & 0.13 & 0.14 & 0.13 & 0.15 & 0.13 & 0.16 & 0.13 & 0.16 & 0.13 & 0.16 & 0.14 & 0.16 \\
\hline $\mathrm{SO}_{3}$ & 0.36 & 0.33 & 0.37 & 0.32 & 0.38 & 0.36 & 0.38 & 0.38 & 0.38 & 0.36 & 0.38 & 0.36 \\
\hline SUM & 100.0 & 100.5 & 100.0 & 100.5 & 100.0 & 100.3 & 100.0 & 100.5 & 100.0 & 100.2 & 100.0 & 100.5 \\
\hline
\end{tabular}

* Analyzed by X-ray fluorescence except for boron which was measured by DCP

NA - Not analyzed (SUM includes target fluorine value) 
Table 2.32. Target and Analyzed Compositions (wt\%) of Twelve ORPLG Crucible Glasses (continued).

\begin{tabular}{|c|c|c|c|c|c|c|c|c|c|c|c|c|}
\hline GLASS & \multicolumn{2}{|c|}{ ORPLG7 } & \multicolumn{2}{|c|}{ ORPLG8 } & \multicolumn{2}{|c|}{ ORPLG9 } & \multicolumn{2}{|c|}{ ORPLG10 } & \multicolumn{2}{|c|}{ ORPLG11 } & \multicolumn{2}{|c|}{ ORPLG12 } \\
\hline Oxides & Target & Analyzed* & Target & Analyzed* & Target & Analyzed* & Target & Analyzed* & Target & Analyzed* & Target & Analyzed \\
\hline $\mathrm{Al}_{2} \mathrm{O}_{3}$ & 6.77 & 6.55 & 6.75 & 6.54 & 6.74 & 6.48 & 6.72 & 6.44 & 6.75 & 6.43 & 6.75 & 6.44 \\
\hline $\mathrm{B}_{2} \mathrm{O}_{3}$ & 8.65 & 8.45 & 8.57 & 8.44 & 8.49 & 8.39 & 8.40 & 8.35 & 8.57 & 8.48 & 8.57 & 8.42 \\
\hline $\mathrm{CaO}$ & 2.74 & 2.94 & 2.71 & 2.97 & 2.69 & 2.93 & 2.66 & 2.89 & 3.96 & 4.35 & 2.71 & 2.91 \\
\hline $\mathrm{Cr}_{2} \mathrm{O}_{3}$ & 0.59 & 0.74 & 0.59 & 0.75 & 0.59 & 0.74 & 0.59 & 0.74 & 0.59 & 0.78 & 0.59 & 0.77 \\
\hline $\mathrm{Fe}_{2} \mathrm{O}_{3}$ & 0.29 & 0.32 & 0.29 & 0.33 & 0.28 & 0.33 & 0.28 & 0.32 & 0.00 & 0.00 & 0.29 & 0.32 \\
\hline $\mathrm{K}_{2} \mathrm{O}$ & 5.47 & 5.45 & 5.61 & 5.75 & 5.75 & 5.87 & 5.88 & 6.05 & 5.61 & 5.74 & 5.61 & 5.64 \\
\hline $\mathrm{MgO}$ & 0.97 & 0.85 & 0.96 & 0.87 & 0.95 & 0.82 & 0.94 & 0.85 & 0.00 & 0.00 & 0.96 & 0.86 \\
\hline $\mathrm{Na}_{2} \mathrm{O}$ & 20.00 & 20.20 & 20.50 & 19.96 & 21.00 & 20.18 & 21.50 & 20.79 & 20.50 & 19.45 & 20.50 & 20.79 \\
\hline $\mathrm{NiO}$ & 0.01 & 0.01 & 0.01 & 0.01 & 0.01 & 0.01 & 0.01 & 0.01 & 0.01 & 0.02 & 0.01 & 0.03 \\
\hline $\mathrm{PbO}$ & 0.01 & 0.01 & 0.01 & 0.02 & 0.01 & 0.02 & 0.01 & 0.03 & 0.01 & 0.02 & 0.01 & 0.02 \\
\hline $\mathrm{SiO}_{2}$ & 41.55 & 41.27 & 41.15 & 41.26 & 40.75 & 40.42 & 40.35 & 40.31 & 41.15 & 40.61 & 41.15 & 40.57 \\
\hline $\mathrm{SnO}_{2}$ & 2.88 & 3.08 & 2.86 & 3.01 & 2.83 & 3.40 & 2.80 & 3.21 & 2.86 & 3.49 & 2.86 & 3.08 \\
\hline $\mathrm{ZnO}$ & 3.46 & 3.52 & 3.43 & 3.58 & 3.39 & 3.63 & 3.36 & 3.50 & 3.43 & 3.71 & 3.43 & 3.54 \\
\hline $\mathrm{ZrO}_{2}$ & 5.77 & 5.39 & 5.71 & 5.36 & 5.66 & 5.60 & 5.60 & 5.39 & 5.71 & 5.78 & 3.86 & 3.61 \\
\hline $\mathrm{Cl}$ & 0.22 & 0.22 & 0.23 & 0.23 & 0.23 & 0.23 & 0.24 & 0.23 & 0.23 & 0.23 & 0.23 & 0.23 \\
\hline $\mathrm{F}$ & 0.09 & NA & 0.09 & NA & 0.09 & NA & 0.09 & NA & 0.09 & NA & 0.09 & NA \\
\hline $\mathrm{P}_{2} \mathrm{O}_{5}$ & 0.14 & 0.16 & 0.14 & 0.15 & 0.14 & 0.16 & 0.15 & 0.17 & 0.14 & 0.17 & 2.00 & 2.05 \\
\hline $\mathrm{SO}_{3}$ & 0.39 & 0.35 & 0.40 & 0.36 & 0.41 & 0.36 & 0.42 & 0.40 & 0.40 & 0.38 & 0.40 & 0.35 \\
\hline SUM & 100.0 & 99.6 & 100.0 & 99.7 & 100.0 & 99.7 & 100.0 & 99.8 & 100.0 & 99.7 & 100.0 & 99.7 \\
\hline
\end{tabular}

* Analyzed by X-ray fluorescence except for boron which was measured by DCP

NA - Not analyzed (SUM includes target fluorine value) 
Table 2.33. Descriptions of Twelve As-Melted and Heat Treated ORPLG Crucible Glasses.

\begin{tabular}{|c|c|c|}
\hline Glass ID & As-melted glass & $\begin{array}{l}\text { Glass remelted at } 1200^{\circ} \mathrm{C} \text { for } 1 \text { hour, heat treated for } 20 \text { hours at } \\
\qquad 950^{\circ} \mathrm{C} \text {, and quenched. }\end{array}$ \\
\hline ORPLG1 & Mostly clear glass. $\sim 0.1$ vol\% tiny Cr oxide crystals & Mostly clear glass. $\sim 0.2$ vol\% tiny Cr oxide crystals \\
\hline ORPLG2 & Mostly clear glass. $\sim 0.1$ vol\% tiny Cr oxide crystals & Mostly clear glass. $\sim 0.2$ vol\% tiny Cr oxide crystals \\
\hline ORPLG3 & Mostly clear glass. $\sim 0.1$ vol\% tiny Cr oxide crystals & Mostly clear glass. $\sim 0.2$ vol\% tiny Cr oxide crystals \\
\hline ORPLG4 & Mostly clear glass. $\sim 0.2$ vol\% tiny Cr oxide crystals & Mostly clear glass. $\sim 0.2$ vol\% tiny Cr oxide crystals \\
\hline ORPLG5 & Mostly clear glass. $~ 0.1$ vol\% tiny Cr oxide crystals & Mostly clear glass. $\sim 0.2$ vol\% tiny Cr oxide crystals \\
\hline ORPLG6 & Mostly clear glass. $\sim 0.1$ vol\% tiny Cr oxide crystals & Mostly clear glass. $\sim 0.2$ vol\% tiny Cr oxide crystals \\
\hline ORPLG7 & Clear glass. $<<0.1$ vol\% Cr-Zn oxide crystals & Mostly clear glass. $~ 0.2-0.3$ vol\% tiny Cr oxide crystals \\
\hline ORPLG8 & Clear glass. $<<0.1$ vol\% Cr-Zn oxide crystals & Mostly clear glass. $\sim 0.2-0.3$ vol\% tiny Cr oxide crystals \\
\hline ORPLG9 & Clear glass. $<<0.1$ vol\% Cr-Zn oxide crystals & Mostly clear glass. $~ 0.2-0.3$ vol\% tiny Cr oxide crystals \\
\hline ORPLG10 & Clear glass. $<<0.1$ vol\% Cr-Zn oxide crystals & Mostly clear glass. $~ 0.2$ vol\% tiny Cr oxide \& NaZrSn silicate crystals \\
\hline ORPLG11 & Clear glass. $<<0.1$ vol\% Cr-Zn oxide crystals & Mostly clear glass. $\sim 0.2$ vol\% tiny Cr oxide \& NaZrSn silicate crystals \\
\hline ORPLG12 & Mostly clear glass. $\sim 0.1$ vol\% tiny Cr oxide crystals & Mostly clear glass. $\sim 0.1$ vol\% tiny Cr oxide crystals \\
\hline
\end{tabular}


Table 2.34. Measured Sulfate Solubility Limits in Twelve ORPLG Crucible Glasses.

\begin{tabular}{|c|c|c|c|}
\hline \multirow{3}{*}{ Sample ID } & \multicolumn{3}{|c|}{$\mathrm{SO}_{3}$ Content (wt \%) } \\
\hline & \multicolumn{2}{|c|}{ Batch Saturation } & \multirow{2}{*}{ Bubbling* } \\
\hline & As-Melted & After Acid Wash & \\
\hline ORPLG1S4 & 0.38 & 0.36 & - \\
\hline ORPLG2S4 & 0.40 & 0.38 & - \\
\hline ORPLG3S4 & 0.40 & 0.40 & - \\
\hline ORPLG4S4 & 0.44 & 0.43 & - \\
\hline ORPLG5S4 & 0.41 & 0.40 & - \\
\hline ORPLG6S4 & 0.47 & 0.45 & - \\
\hline ORPLG7S4 & 0.46 & 0.44 & - \\
\hline ORPLG8S4 & 0.49 & 0.46 & - \\
\hline ORPLG9S4 & 0.52 & 0.48 & $\begin{array}{c}0.65 \text { (sulfate layer onset at } \\
0.31 \mathrm{wt} \% \mathrm{SO}_{3} \text { ) }\end{array}$ \\
\hline ORPLG9CrS4 $\$$ & - & - & $\begin{array}{c}0.55 \text { (sulfate layer onset at } \\
0.17 \mathrm{wt} \% \mathrm{SO}_{3} \text { ) }\end{array}$ \\
\hline ORPLG10S4 & 0.54 & 0.49 & - \\
\hline ORPLG11S4 & 0.49 & 0.48 & - \\
\hline ORPLG12S4 & 0.50 & 0.47 & - \\
\hline
\end{tabular}

- Empty data field

* Starting glass for bubbling tests contained no $\mathrm{SO}_{3}$.

$\$$ Additional $0.4 \mathrm{wt} \% \mathrm{Cr}_{2} \mathrm{O}_{3}$ was added to this glass - sulfate layer was observed immediately upon bubbling at $\mathrm{SO}_{3}$ concentration of $0.17 \mathrm{wt} \%$ in the glass. 
Table 2.35. Results of 7-day PCT (at $90^{\circ} \mathrm{C}$ ) and VHT (at $200^{\circ} \mathrm{C}$ for 24 Days) for Twelve ORPLG Crucible Glasses.

\begin{tabular}{|c|c|c|c|c|c|c|c|c|c|c|c|c|}
\hline Glass ID & ORPLG1 & ORPLG2 & ORPLG3 & ORPLG4 & ORPLG5 & ORPLG6 & ORPLG7 & ORPLG8 & ORPLG9 & ORPLG10 & ORPLG11 & ORPLG12 \\
\hline \multicolumn{13}{|c|}{ 7-Day PCT, Stainless Steel Vessel; $\mathbf{S} / \mathbf{V}=\mathbf{2 0 0 0 \mathrm { m } ^ { - 1 }}$ (ppm) } \\
\hline B & 13.06 & 42.17 & 24.40 & 25.89 & 15.48 & 16.23 & 16.64 & 16.09 & 27.42 & 25.48 & 29.38 & 39.18 \\
\hline $\mathrm{Na}$ & 87.99 & 267.00 & 196.70 & 191.10 & 121.60 & 127.70 & 132.90 & 131.10 & 172.50 & 168.40 & 185.80 & 238.50 \\
\hline $\mathrm{Si}$ & 46.65 & 84.53 & 74.25 & 86.53 & 49.27 & 49.69 & 55.52 & 51.92 & 63.57 & 65.68 & 69.84 & 79.60 \\
\hline \multicolumn{13}{|c|}{ Normalized Concentrations (g/L) } \\
\hline B & 0.47 & 1.62 & 0.92 & 0.97 & 0.57 & 0.60 & 0.61 & 0.59 & 1.02 & 0.95 & 1.10 & 1.49 \\
\hline $\mathrm{Na}$ & 0.64 & 1.67 & 1.29 & 1.26 & 0.86 & 0.88 & 0.92 & 0.91 & 1.18 & 1.13 & 1.22 & 1.53 \\
\hline $\mathrm{Si}$ & 0.24 & 0.45 & 0.39 & 0.45 & 0.26 & 0.26 & 0.29 & 0.27 & 0.32 & 0.34 & 0.36 & 0.42 \\
\hline $\mathrm{pH}$ & 11.18 & 11.78 & 11.68 & 11.52 & 11.32 & 11.42 & 11.42 & 11.45 & 11.60 & 11.52 & 11.58 & 11.68 \\
\hline \multicolumn{13}{|c|}{ 7-Day PCT Normalized Mass Loss $\left(\mathrm{g} / \mathrm{m}^{2}\right)$} \\
\hline B & 0.24 & 0.81 & 0.46 & 0.49 & 0.29 & 0.30 & 0.31 & 0.30 & 0.51 & 0.47 & 0.55 & 0.74 \\
\hline $\mathrm{Na}$ & 0.32 & 0.84 & 0.65 & 0.63 & 0.43 & 0.44 & 0.46 & 0.45 & 0.59 & 0.57 & 0.61 & 0.77 \\
\hline $\mathrm{Si}$ & 0.12 & 0.22 & 0.19 & 0.22 & 0.13 & 0.13 & 0.15 & 0.14 & 0.16 & 0.17 & 0.18 & 0.21 \\
\hline \multicolumn{13}{|c|}{ 7-Day PCT Normalized Loss Rate $\left(\mathrm{g} / \mathrm{m}^{2} / \mathrm{d}\right)$} \\
\hline B & 0.03 & 0.12 & 0.07 & 0.07 & 0.04 & 0.04 & 0.04 & 0.04 & 0.07 & 0.07 & 0.08 & 0.11 \\
\hline $\mathrm{Na}$ & 0.05 & 0.12 & 0.09 & 0.09 & 0.06 & 0.06 & 0.07 & 0.06 & 0.08 & 0.08 & 0.09 & 0.11 \\
\hline $\mathrm{Si}$ & 0.02 & 0.03 & 0.03 & 0.03 & 0.02 & 0.02 & 0.02 & 0.02 & 0.02 & 0.02 & 0.03 & 0.03 \\
\hline \multicolumn{13}{|c|}{ VHT Alteration ( 24 days at $200^{\circ} \mathrm{C}$ ) } \\
\hline $\begin{array}{c}\text { Alteration } \\
\text { Depth }(\mu \mathrm{m})\end{array}$ & 17 & 22 & 105 & 185 & 36 & 102 & 98 to 200 & 231 to 400 & 370 to 450 & 766 to 825 & 78 & 725 to 925 \\
\hline $\begin{array}{c}\text { Alteration Rate } \\
\left(\mathrm{g} / \mathrm{m}^{2} / \mathrm{day}\right)^{*}\end{array}$ & 2 & 2 & 12 & 20 & 4 & 11 & 11 to 22 & 26 to 44 & 41 to 50 & 85 to 91 & 9 & 80 to 102 \\
\hline
\end{tabular}


Table 2.36. Viscosities and Electrical Conductivities of Eleven ORPLG Crucible Glasses.

\begin{tabular}{|c|c|c|c|c|c|c|c|c|c|c|c|}
\hline $\begin{array}{c}\text { Glass } \\
\text { ID }\end{array}$ & ORPLG1 & ORPLG2 & ORPLG4 & ORPLG5 & ORPLG6 & ORPLG7 & ORPLG8 & ORPLG9 & ORPLG10 & ORPLG11 & ORPLG12 \\
\hline \multicolumn{12}{|c|}{ Viscosity (poise) } \\
\hline $900^{\circ} \mathrm{C}$ & 7260 & 6099 & 5159 & 4732 & 3072 & 3348 & 2153 & 1795 & 1444 & 2167 & 1630 \\
\hline $950^{\circ} \mathrm{C}$ & 2554 & 2169 & 1736 & 1664 & 1040 & 1173 & 840 & 702 & 580 & 796 & 675 \\
\hline $1000^{\circ} \mathrm{C}$ & 1041 & 891 & 707 & 693 & 430 & 483 & 373 & 315 & 264 & 342 & 314 \\
\hline $1050^{\circ} \mathrm{C}$ & 477 & 410 & 333 & 329 & 207 & 226 & 184 & 158 & 133 & 166 & 161 \\
\hline $1100^{\circ} \mathrm{C}$ & 241 & 208 & 176 & 173 & 111 & 117 & 99 & 86 & 73 & 89 & 89 \\
\hline $1150^{\circ} \mathrm{C}$ & 132 & 114 & 101 & 99 & 66 & 66 & 57 & 51 & 43 & 52 & 53 \\
\hline $1200^{\circ} \mathrm{C}$ & 77 & 67 & 63 & 61 & 42 & 39 & 35 & 32 & 26 & 32 & 33 \\
\hline $1250^{\circ} \mathrm{C}$ & 48 & 41 & 41 & 39 & 28 & 25 & 22 & 21 & 17 & 21 & 22 \\
\hline \multicolumn{12}{|c|}{ Electrical Conductivity (S/cm) } \\
\hline $900^{\circ} \mathrm{C}$ & 0.078 & 0.074 & 0.124 & 0.115 & 0.129 & 0.133 & 0.190 & 0.148 & 0.142 & 0.139 & 0.150 \\
\hline $950^{\circ} \mathrm{C}$ & 0.117 & 0.116 & 0.163 & 0.156 & 0.168 & 0.171 & 0.233 & 0.224 & 0.198 & 0.196 & 0.208 \\
\hline $1000^{\circ} \mathrm{C}$ & 0.162 & 0.163 & 0.208 & 0.204 & 0.213 & 0.215 & 0.282 & 0.304 & 0.265 & 0.258 & 0.274 \\
\hline $1050^{\circ} \mathrm{C}$ & 0.210 & 0.215 & 0.259 & 0.258 & 0.266 & 0.265 & 0.336 & 0.385 & 0.344 & 0.323 & 0.347 \\
\hline $1100^{\circ} \mathrm{C}$ & 0.260 & 0.269 & 0.315 & 0.317 & 0.326 & 0.323 & 0.395 & 0.464 & 0.434 & 0.390 & 0.427 \\
\hline $1150^{\circ} \mathrm{C}$ & 0.312 & 0.324 & 0.377 & 0.380 & 0.394 & 0.388 & 0.459 & 0.539 & 0.535 & 0.457 & 0.512 \\
\hline $1200^{\circ} \mathrm{C}$ & 0.364 & 0.380 & 0.443 & 0.448 & 0.471 & 0.460 & 0.529 & 0.611 & 0.646 & 0.523 & 0.602 \\
\hline $1250^{\circ} \mathrm{C}$ & 0.416 & 0.435 & 0.513 & 0.519 & 0.556 & 0.539 & 0.603 & 0.678 & 0.768 & 0.589 & 0.695 \\
\hline
\end{tabular}


Table 2.37. Results of K-3 Corrosion Testing for Eight ORPLG Crucible Glasses.

\begin{tabular}{|c|c|c|c|}
\hline Glass ID & $\begin{array}{l}\text { Neck loss } \\
\text { (inches) }\end{array}$ & $\begin{array}{l}\text { Depth of altered } \\
\text { zone (inches) }\end{array}$ & $\begin{array}{l}\text { Half-down loss } \\
\quad \text { (inches) }\end{array}$ \\
\hline ORPLG5 & 0.0160 & 0.027 & 0.001 \\
\hline ORPLG6 & 0.0225 & 0.026 & $\begin{array}{c}\text { Coupon expanded - no } \\
\text { measurable loss }\end{array}$ \\
\hline ORPLG7 & 0.0265 & 0.027 & $\begin{array}{c}\text { Coupon expanded - no } \\
\text { measurable loss }\end{array}$ \\
\hline ORPLG8 & 0.0360 & 0.0255 & $\begin{array}{c}\text { Coupon expanded - no } \\
\text { measurable loss }\end{array}$ \\
\hline ORPLG9 & 0.0380 & 0.040 & $\begin{array}{c}\text { Coupon expanded - no } \\
\text { measurable loss at half } \\
\text { down but a large crack } \\
\text { in this coupon's half } \\
\text { down region which } \\
\text { resulted in part of the } \\
\text { coupon falling into the } \\
\text { molten glass }\end{array}$ \\
\hline ORPLG10 & 0.0415 & 0.023 & 0.0025 \\
\hline ORPLG11 & 0.0600 & 0.025 & 0.0005 \\
\hline ORPLG12 & 0.0245 & 0.024 & $\begin{array}{c}\text { Coupon expanded - no } \\
\text { measurable loss }\end{array}$ \\
\hline
\end{tabular}


Table 2.38. Summary of Test Results for Selected ORPLG Glass Formulation ORPLG9 and Comparison to ILAW Requirements.

\begin{tabular}{|c|c|c|}
\hline Test & Requirement $[53,54]$ & $\begin{array}{l}\text { Test Result for } \\
\text { ORPLG9 }\end{array}$ \\
\hline Density of glass & $<3.7 \mathrm{~g} / \mathrm{cc}$ & $2.56 \mathrm{~g} / \mathrm{cc}$ \\
\hline Crystalline Phase & Phase identification & $\begin{array}{c}\text { Clear glass. }<<0.1 \text { vol\% of small Cr } \\
\text { crystals }\end{array}$ \\
\hline Liquidus & $<950^{\circ} \mathrm{C}$ & $<950^{\circ} \mathrm{C}$ \\
\hline Centerline Canister Cooling & Phase identification & Not measured \\
\hline PCT B $\left(\mathrm{g} / \mathrm{m}^{2}\right)$ & $<2.0 \mathrm{~g} / \mathrm{m}^{2}$ & $0.51 \mathrm{~g} / \mathrm{m}^{2}$ \\
\hline PCT Na $\left(\mathrm{g} / \mathrm{m}^{2}\right)$ & $<2.0 \mathrm{~g} / \mathrm{m}^{2}$ & $0.59 \mathrm{~g} / \mathrm{m}^{2}$ \\
\hline PCT Si $\left(g / m^{2}\right)$ & $<2.0 \mathrm{~g} / \mathrm{m}^{2}$ & $0.16 \mathrm{~g} / \mathrm{m}^{2}$ \\
\hline VHT at $200^{\circ} \mathrm{C}\left(\mathrm{g} / \mathrm{m}^{2} /\right.$ day $)$ & $<50 \mathrm{~g} / \mathrm{m}^{2} /$ day & $\begin{array}{l}41 \text { to } 50 \mathrm{~g} / \mathrm{m}^{2} / \text { day } \\
\text { (variations in the hydration thickness) }\end{array}$ \\
\hline Viscosity (poise) at $1100^{\circ} \mathrm{C}$ & 10 to $150 \mathrm{P}$ & $128 \mathrm{P}$ \\
\hline Conductivity $(\mathrm{S} / \mathrm{cm})$ at $1100^{\circ} \mathrm{C}$ & 0.2 to $0.7 \mathrm{~S} / \mathrm{cm}$ & $0.445 \mathrm{~S} / \mathrm{cm}$ \\
\hline $\mathrm{T}_{\mathrm{G}}\left({ }^{\circ} \mathrm{C}\right)$ & Report for modeling & Not measured \\
\hline
\end{tabular}

*Density measured for melter glass 10A-G-43B of the ORPLG9 composition 
Table 2.39. Oxide Composition of AP-101 Simulant and ORPLG9 Glass Composition Used in Melter Tests (wt\%).

\begin{tabular}{|c|c|c|c|}
\hline Component & AP-101 waste contribution & $\begin{array}{l}\text { Glass former } \\
\text { additives }\end{array}$ & $\begin{array}{c}\text { ORPLG9 } \\
\text { (for AP-101) }\end{array}$ \\
\hline Loading & $29.10 \%$ & $70.90 \%$ & - \\
\hline $\mathrm{Al}_{2} \mathrm{O}_{3}$ & 1.540 & 5.22 & 6.76 \\
\hline $\mathrm{B}_{2} \mathrm{O}_{3}$ & 0.003 & 8.51 & 8.51 \\
\hline $\mathrm{CaO}$ & - & 2.70 & 2.70 \\
\hline $\mathrm{Cr}_{2} \mathrm{O}_{3}$ & 0.093 & 0.50 & 0.59 \\
\hline $\mathrm{Fe}_{2} \mathrm{O}_{3}$ & - & 0.20 & 0.20 \\
\hline $\mathrm{K}_{2} \mathrm{O}$ & 5.755 & - & 5.76 \\
\hline $\mathrm{MgO}$ & - & 0.96 & 0.96 \\
\hline $\mathrm{Na}_{2} \mathrm{O}^{(\mathrm{a})}$ & $20.210+0.155^{(1)}+0.635^{(2)}$ & - & 21.00 \\
\hline $\mathrm{NiO}$ & 0.009 & & 0.01 \\
\hline $\mathrm{PbO}$ & 0.009 & & 0.01 \\
\hline $\mathrm{SiO}_{2}$ & 0.028 & 40.89 & 40.92 \\
\hline $\mathrm{SnO}_{2}$ & - & 2.84 & 2.84 \\
\hline $\mathrm{ZnO}$ & - & 3.40 & 3.40 \\
\hline $\mathrm{ZrO}_{2}$ & - & 5.68 & 5.68 \\
\hline $\mathrm{Cl}$ & 0.231 & - & 0.23 \\
\hline $\mathrm{F}$ & 0.092 & - & 0.09 \\
\hline $\mathrm{P}_{2} \mathrm{O}_{5}$ & 0.142 & - & 0.14 \\
\hline $\mathrm{SO}_{3}{ }^{(\mathrm{b})}$ & $0.200^{(1)}$ & - & 0.20 \\
\hline SUM & 29.1 & 70.90 & 100.0 \\
\hline
\end{tabular}

(a) Simulant was ordered at a concentration of $20.21 \mathrm{wt} \% \mathrm{Na}_{2} \mathrm{O}$ and modified before each melter test with (1) $\mathrm{Na}_{2} \mathrm{SO}_{4}$ and (2) $\mathrm{NaOH}$ additions to obtain $21.0 \mathrm{wt} \% \mathrm{Na}_{2} \mathrm{O}$ in the glass.

(b) Concentration of $\mathrm{SO}_{3}$ was varied in steps during the melter tests.

- Empty data field 
Table 2.40a. Glass Former Additives for 1 Liter of AP-101 Simulant (8.45 M Na) and Corresponding Melter Feed Properties.

\begin{tabular}{|c|c|}
\hline Additives Source & Feed ORPLG9 \\
\hline Additives in Glass (wt\%) & 70.9 \\
\hline Kyanite $\left(\mathrm{Al}_{2} \mathrm{SiO}_{5}\right) 325$ Mesh (Kyanite Mining) (g) & 106.81 \\
\hline $\mathrm{H}_{3} \mathrm{BO}_{3}$ (US Borax - Technical Granular) (g) & 177.96 \\
\hline Wollanstonite NYAD 325 Mesh (NYCO Minerals) (g) & 69.87 \\
\hline $\mathrm{Cr}_{2} \mathrm{O}_{3}$ oxide & 5.99 \\
\hline Olivine $\left(\mathrm{Mg}_{2} \mathrm{SiO}_{4}\right) 325 \mathrm{Mesh}(\# 180$ Unimin) (g) & 22.47 \\
\hline $\mathrm{SiO}_{2}$ (Sil-co-Sil 75 US Silica) (g) & 357.13 \\
\hline SnO2 - Stannous Oxide - Mason color & 33.54 \\
\hline ZnO (KADOX - 920 Zinc Corp. of America) (g) & 40.07 \\
\hline Zircon $\mathrm{ZrSiO}_{4}$ (Flour) Mesh 325 (AM. Mineral) (g) & 100.86 \\
\hline $\mathrm{Na}_{2} \mathrm{SO}_{4}$ & Variable - Table $2.40 \mathrm{~b}$ \\
\hline Addition of Sucrose as Reductant (g) & 83.66 \\
\hline Simulant Weight for 1 liter (g) & 1348 \\
\hline Sum of Additives (g) & 998 \\
\hline Sum of Complete Batch (g) & 2346 \\
\hline Target Final Volume (l) & 1.35 \\
\hline Estimated Density $(\mathrm{g} / \mathrm{ml})$ & 1.70 \\
\hline Target Glass Produced (g) & 1181 \\
\hline Target Weight \% Additives in Slurry & 39 \\
\hline Target Glass Yield (g/kg of Feed) & 503 \\
\hline Target Glass Yield (g/l of Feed) & 875 \\
\hline Target Total Solids ( $\mathrm{g} / \mathrm{l}$ of Feed) & 1126 \\
\hline Target Additives (g/l of Feed) & 678 \\
\hline
\end{tabular}

Table 2.40b. $\mathrm{NaOH}$ and $\mathrm{Na}_{2} \mathrm{SO}_{4}$ Additions Required to Obtain $21.0 \mathrm{wt} \% \mathrm{Na}_{2} \mathrm{O}$ and Various $\mathrm{SO}_{3}$ Concentrations in the ORPLG9 Glass.

\begin{tabular}{|c|c|c|}
\hline $\begin{array}{c}\text { Final } \\
\mathrm{SO}_{3} \mathrm{wt} \%\end{array}$ & $\begin{array}{c}\mathrm{NaOH} \text { needed } \\
\text { per kg of feed } \\
\text { (grams) }\end{array}$ & $\begin{array}{c}\mathrm{Na}_{2} \mathrm{SO}_{4} \text { needed } \\
\text { per kg of feed } \\
\text { (grams) }\end{array}$ \\
\hline 0.0 & 10.39 & - \\
\hline 0.1 & 9.37 & 0.92 \\
\hline 0.2 & 8.35 & 1.83 \\
\hline 0.3 & 6.31 & 2.75 \\
\hline
\end{tabular}


The Catholic University of America Vitreous State Laboratory
Glass Formulation Development and DM10 Melter Testing with ORP LAW Glasses

Final Report, VSL-09R1510-2, Rev. 0

Table 2.41. Characteristics of Melter Feed Samples During DM10 ORP LAW Tests.

\begin{tabular}{|c|c|c|c|c|c|c|c|c|c|c|}
\hline \multirow{3}{*}{$\begin{array}{l}\text { Tank Waste/ } \\
\text { Sub-Envelope } \\
\text { Identification }\end{array}$} & \multirow{3}{*}{ Test } & \multirow{3}{*}{ Date } & \multirow{3}{*}{ Name } & \multirow{3}{*}{$\begin{array}{l}\text { Water } \\
\text { (wt\%) }\end{array}$} & \multirow{3}{*}{ pH } & \multirow{3}{*}{$\begin{array}{l}\text { Density } \\
\text { (g/ml) }\end{array}$} & \multicolumn{4}{|c|}{ Glass Yield } \\
\hline & & & & & & & \multirow{2}{*}{$(g / l)$} & Measured & Target & \multirow{2}{*}{ \%Dev. } \\
\hline & & & & & & & & $(\mathrm{kg} / \mathrm{kg})$ & $(\mathrm{kg} / \mathrm{kg})$ & \\
\hline \multirow{5}{*}{$\begin{array}{c}\text { AN-105/ } \\
\text { Sub-Envelope } \\
\text { A1 }\end{array}$} & A & $10 / 17 / 08$ & Z10-F-11A & 42.29 & 13.17 & 1.66 & 566 & 0.341 & 0.470 & -27.51 \\
\hline & \multicolumn{3}{|c|}{ Average ( LAWA187) [6] } & 42.37 & 11.83 & 1.64 & 725 & 0.442 & & \\
\hline & \multicolumn{3}{|c|}{ Average ( LAWA161) [2] } & 38.70 & 11.50 & 1.68 & 791 & 0.472 & & \\
\hline & \multicolumn{3}{|c|}{$\begin{array}{c}\text { High Temperature Test Average } \\
{[3]}\end{array}$} & 38.40 & 11.96 & 1.69 & 788 & 0.467 & & \\
\hline & \multicolumn{3}{|c|}{ DM1200 Average [61] } & 37.60 & 12.19 & 1.72 & 827 & 0.481 & & \\
\hline \multirow{4}{*}{$\begin{array}{c}\text { AN-102/ } \\
\text { Sub-Envelope } \\
\text { C2 }\end{array}$} & \multirow{2}{*}{$\mathrm{D}$} & $10 / 24 / 08$ & Z10-F-61A & 37.03 & 7.55 & 1.43 & 711 & 0.497 & 0.495 & 0.40 \\
\hline & & $1 / 13 / 09$ & Z10-F-146A & 38.12 & 7.52 & 1.69 & 818 & 0.484 & 0.495 & -2.16 \\
\hline & \multicolumn{3}{|c|}{ Average (LAWC31) [24] } & 39.31 & 9.13 & 1.67 & 765 & 0.466 & & \\
\hline & \multicolumn{3}{|c|}{ DM1200 [62]* } & 38.5 & 8.95 & 1.69 & 821 & 0.485 & & \\
\hline \multirow{5}{*}{$\begin{array}{c}\text { AZ-102/ } \\
\text { Sub-Envelope } \\
\text { B2 }\end{array}$} & \multirow{2}{*}{$\mathrm{F}$} & $12 / 17 / 08$ & Z10-F-69A & 39.94 & 13.00 & 1.71 & 915 & 0.535 & 0.559 & -4.33 \\
\hline & & $1 / 8 / 08$ & Z10-F-123A & 39.60 & 11.98 & 1.70 & 917 & 0.540 & 0.559 & -3.47 \\
\hline & \multicolumn{3}{|c|}{ LAWB96 + 15\% Simulant [22] } & 47.07 & 8.75 & 1.58 & 729 & 0.463 & & \\
\hline & \multicolumn{3}{|c|}{ LAWB96 - 15\% Simulant [22] } & 38.76 & 8.70 & 1.69 & 891 & 0.527 & & \\
\hline & \multicolumn{3}{|c|}{ Average LAWB99 [6] } & 44.09 & 8.90 & 1.62 & 786 & 0.485 & & \\
\hline \multirow{6}{*}{$\begin{array}{c}\text { AP-101/ } \\
\text { Sub-Envelope } \\
\text { A2 }\end{array}$} & \multirow{4}{*}{ G } & $12 / 17 / 08$ & Z10-F-69B & 37.28 & NR & 1.72 & 881 & 0.514 & 0.509 & 0.88 \\
\hline & & $1 / 8 / 09$ & Z10-F-129A & 36.81 & 12.30 & 1.73 & 835 & 0.483 & 0.509 & -5.17 \\
\hline & & $1 / 12 / 09$ & Z10-F-141A & 36.05 & 12.77 & 1.75 & 868 & 0.496 & 0.509 & -2.51 \\
\hline & & $1 / 16 / 09$ & 10A-F-52A & 35.66 & 13.39 & 1.75 & 865 & 0.494 & 0.509 & -2.87 \\
\hline & \multicolumn{3}{|c|}{ DM1200 MACT [63] } & 35.40 & 12.25 & 1.74 & 885 & 0.505 & & \\
\hline & \multicolumn{3}{|c|}{ Average LAWA126 [26\} } & 36.01 & 12.50 & 1.73 & 820 & 0.474 & & \\
\hline
\end{tabular}

* This is an AN-107, Sub-Envelope C1 feed. 
Table 2.42. Target and XRF Analyzed Composition of Vitrified Melter Feed Samples (wt\%).

\begin{tabular}{|c|c|c|c|c|c|c|c|c|c|}
\hline Test & \multirow{2}{*}{\multicolumn{3}{|c|}{$\begin{array}{l}\text { A (ORPLA20) } \\
\text { tomposite Melter Feed }\end{array}$}} & \multicolumn{6}{|c|}{ D (ORPLD6) } \\
\hline \multirow{2}{*}{$\begin{array}{c}\text { Sample Info } \\
\text { Constituent }\end{array}$} & & & & Melte & eed fron & Test 4 & Comp & site Melt & Feed \\
\hline & Target** & $\begin{array}{c}\text { Z10-F- } \\
11 \mathrm{~A}\end{array}$ & \%Dev. & Target & $\begin{array}{l}\text { Z10-F- } \\
146 A\end{array}$ & $\%$ Dev. & Target** & $\begin{array}{c}\text { Z10-F- } \\
61 \mathrm{~A}\end{array}$ & \%Dev. \\
\hline $\mathrm{Al}_{2} \mathrm{O}_{3}$ & 6.65 & 6.54 & -1.74 & 10.09 & 9.79 & -3.02 & 10.11 & 10.19 & 0.86 \\
\hline $\mathrm{B}_{2} \mathrm{O}_{3} *$ & 8.74 & 8.74 & NC & 9.85 & 9.85 & NC & 9.86 & 9.86 & $\mathrm{NC}$ \\
\hline $\mathrm{CaO}$ & 3.32 & 4.10 & 23.39 & 7.89 & 7.55 & -4.38 & 7.90 & 7.41 & -6.20 \\
\hline $\mathrm{Cl}$ & 0.67 & 0.58 & NC & 0.35 & 0.20 & NC & 0.35 & 0.26 & NC \\
\hline $\mathrm{Cr}_{2} \mathrm{O}_{3}$ & 0.50 & 0.70 & NC & 0.50 & 0.62 & NC & 0.50 & 0.62 & $\mathrm{NC}$ \\
\hline $\mathrm{Cs} 2 \mathrm{O}$ & $\S$ & $<0.01$ & $\mathrm{NC}$ & $\S$ & $<0.01$ & $\mathrm{NC}$ & $\S$ & $<0.01$ & $\mathrm{NC}$ \\
\hline $\mathrm{F}^{*}$ & $\S$ & NA & NC & 0.18 & 0.18 & NC & 0.18 & 0.18 & NC \\
\hline $\mathrm{Fe}_{2} \mathrm{O}_{3}$ & 0.19 & 0.32 & $\mathrm{NC}$ & 0.28 & 0.38 & NC & 0.28 & 0.40 & $\mathrm{NC}$ \\
\hline $\mathrm{I}$ & $\S$ & 0.08 & $\mathrm{NC}$ & $\S$ & $<0.01$ & $\mathrm{NC}$ & $\S$ & $<0.01$ & $\mathrm{NC}$ \\
\hline $\mathrm{K}_{2} \mathrm{O}$ & 0.53 & 0.52 & $\mathrm{NC}$ & 0.17 & 0.16 & $\mathrm{NC}$ & 0.17 & 0.20 & $\mathrm{NC}$ \\
\hline $\mathrm{Li}_{2} \mathrm{O}$ & $\S$ & NA & NC & $\S$ & $<0.01$ & NC & $\S$ & NA & $\mathrm{NC}$ \\
\hline $\mathrm{MgO}$ & 0.92 & 1.17 & $\mathrm{NC}$ & 1.00 & 0.75 & $\mathrm{NC}$ & 1.00 & 1.31 & $\mathrm{NC}$ \\
\hline $\mathrm{MnO}$ & $\S$ & 0.01 & $\mathrm{NC}$ & $\S$ & 0.03 & $\mathrm{NC}$ & $\S$ & $<0.01$ & $\mathrm{NC}$ \\
\hline $\mathrm{Na}_{2} \mathrm{O}$ & 24.00 & 22.57 & -5.98 & 22.00 & 22.75 & 3.43 & 22.00 & 22.28 & 1.26 \\
\hline $\mathrm{NiO}$ & $\S$ & $<0.01$ & NC & 0.04 & 0.04 & NC & 0.04 & 0.05 & $\mathrm{NC}$ \\
\hline $\mathrm{P}_{2} \mathrm{O}_{5}$ & $\S$ & 0.02 & NC & 0.30 & 0.40 & NC & 0.30 & 0.37 & NC \\
\hline $\mathrm{PbO}$ & $\S$ & $<0.01$ & $\mathrm{NC}$ & 0.01 & 0.02 & $\mathrm{NC}$ & 0.01 & 0.02 & $\mathrm{NC}$ \\
\hline $\mathrm{SiO}_{2}$ & 42.33 & 42.09 & -0.58 & 37.24 & 37.12 & -0.32 & 37.28 & 35.18 & -5.62 \\
\hline $\mathrm{SnO}_{2}$ & 2.74 & 2.88 & 5.24 & $\S$ & $<0.01$ & $\mathrm{NC}$ & $\S$ & $<0.01$ & $\mathrm{NC}$ \\
\hline $\mathrm{SO}_{3}$ & 0.70 & 0.56 & $\mathrm{NC}$ & 1.20 & 1.03 & $\mathrm{NC}$ & 1.12 & 1.04 & $\mathrm{NC}$ \\
\hline $\mathrm{TiO}_{2}$ & $\S$ & 0.04 & $\mathrm{NC}$ & $\S$ & 0.20 & $\mathrm{NC}$ & $\S$ & 0.29 & $\mathrm{NC}$ \\
\hline $\mathrm{V}_{2} \mathrm{O}_{5}$ & $\S$ & 0.03 & $\mathrm{NC}$ & 1.96 & 2.24 & 14.34 & 1.96 & 2.12 & 8.02 \\
\hline $\mathrm{ZnO}$ & 2.74 & 2.86 & 4.51 & 2.96 & 3.07 & 3.84 & 2.96 & 2.93 & -1.08 \\
\hline $\mathrm{ZrO}_{2}$ & 5.96 & 6.19 & 3.85 & 3.98 & 3.60 & -9.48 & 3.99 & 5.30 & 33.03 \\
\hline Sum & 100.00 & 100.00 & NC & 100.00 & 100.00 & NC & 100.00 & 100.00 & NC \\
\hline
\end{tabular}

* - Target value for $\mathrm{B}_{2} \mathrm{O}_{3}$

** - Target composition calculated based on actual proportion of meter feed residues after test $\S$ - Not a target constituent

NA - Not analyzed

NC - Not calculated 
Table 2.42. Target and XRF Analyzed Composition of Vitrified Melter Feed Samples (wt\%) (continued).

\begin{tabular}{|c|c|c|c|c|c|c|}
\hline \multirow{3}{*}{\begin{tabular}{l}
\multicolumn{1}{c}{ Test } \\
Sample Info \\
Constituent
\end{tabular}} & \multicolumn{6}{|c|}{ F (ORPLF7) } \\
\hline & \multicolumn{3}{|c|}{ Melter Feed Before Sulfur Addition } & \multicolumn{3}{|c|}{ Melter Feed from Test F4 } \\
\hline & Target & Z10-F-69A & \%Dev. & Target & Z10-F-123A & \%Dev. \\
\hline $\mathrm{Al}_{2} \mathrm{O}_{3}$ & 8.92 & 8.79 & -1.39 & 8.72 & 8.31 & -4.76 \\
\hline $\mathrm{B}_{2} \mathrm{O}_{3} *$ & 9.85 & 9.85 & NC & 9.63 & 9.63 & NC \\
\hline $\mathrm{CaO}$ & 10.08 & 9.22 & -8.48 & 9.86 & 9.84 & -0.12 \\
\hline $\mathrm{Cl}$ & 0.01 & 0.02 & NC & 0.01 & 0.01 & $\mathrm{NC}$ \\
\hline $\mathrm{Cr}_{2} \mathrm{O}_{3}$ & 0.58 & 0.81 & NC & 0.57 & 0.80 & NC \\
\hline Cs2O & $\S$ & $<0.01$ & NC & $\S$ & $<0.01$ & NC \\
\hline $\mathrm{F}^{*}$ & 0.07 & 0.07 & NC & 0.08 & 0.08 & NC \\
\hline $\mathrm{Fe}_{2} \mathrm{O}_{3}$ & 0.24 & 0.34 & NC & 0.23 & 0.39 & NC \\
\hline I & $\S$ & $<0.01$ & NC & $\S$ & $<0.01$ & NC \\
\hline $\mathrm{K}_{2} \mathrm{O}$ & 0.45 & 0.56 & NC & 0.50 & 0.53 & NC \\
\hline $\mathrm{Li}_{2} \mathrm{O}^{*}$ & 4.51 & 4.51 & NC & 4.41 & 4.41 & NC \\
\hline $\mathrm{MgO}$ & 1.02 & 1.05 & 3.48 & 0.99 & 1.16 & NC \\
\hline $\mathrm{MnO}$ & $\S$ & 0.01 & NC & $\S$ & 0.01 & NC \\
\hline $\mathrm{Na}_{2} \mathrm{O}$ & 10.84 & 10.80 & -0.38 & 12.00 & 11.54 & -3.81 \\
\hline $\mathrm{NiO}$ & $\S$ & 0.01 & NC & $\S$ & $<0.01$ & $\mathrm{NC}$ \\
\hline $\mathrm{P}_{2} \mathrm{O}_{5}$ & 0.03 & 0.08 & NC & 0.04 & 0.07 & NC \\
\hline $\mathrm{PbO}$ & $\S$ & $<0.01$ & NC & $\S$ & $<0.01$ & NC \\
\hline $\mathrm{SiO}_{2}$ & 43.78 & 43.85 & 0.16 & 42.73 & 42.36 & -0.89 \\
\hline $\mathrm{SnO}_{2}$ & $\S$ & 0.01 & NC & $\S$ & 0.01 & $\mathrm{NC}$ \\
\hline $\mathrm{SO}_{3}$ & $\S$ & 0.06 & NC & 0.80 & 0.92 & NC \\
\hline $\mathrm{TiO}_{2}$ & $\S$ & 0.22 & NC & $\S$ & 0.21 & NC \\
\hline $\mathrm{V}_{2} \mathrm{O}_{5}$ & 2.59 & 2.87 & 10.88 & 2.53 & 2.90 & 14.34 \\
\hline $\mathrm{ZnO}$ & 3.02 & 3.14 & 4.22 & 2.95 & 3.05 & 3.31 \\
\hline $\mathrm{ZrO}_{2}$ & 4.02 & 3.72 & -7.65 & 3.93 & 3.78 & -3.97 \\
\hline Sum & 100.00 & 100.00 & NC & 100.00 & 100.00 & NC \\
\hline
\end{tabular}

* - Target values

$\S$ - Not a target constituent

NA - Not analyzed

NC - Not calculated 
Table 2.42. Target and XRF Analyzed Composition of Vitrified Melter Feed Samples (wt\%) (continued).

\begin{tabular}{|c|c|c|c|c|c|c|c|c|c|}
\hline Test & \multicolumn{9}{|c|}{ G (ORPLG9) } \\
\hline Sample Info & \multicolumn{6}{|c|}{ Melter Feed Before Sulfur Addition } & \multicolumn{3}{|c|}{ Composite Melter Feed } \\
\hline Constituent & Target & $\begin{array}{c}\text { Z10-F- } \\
129 A\end{array}$ & $\begin{array}{c}\text { Z10-F- } \\
141 \mathrm{~A}\end{array}$ & $\begin{array}{c}\text { Z10-F- } \\
\text { 69B }\end{array}$ & Avg. & \%Dev. & Target** & $\begin{array}{c}\text { 10A-F- } \\
52 \mathrm{~A}\end{array}$ & \%Dev. \\
\hline $\mathrm{Al}_{2} \mathrm{O}_{3}$ & 6.79 & 6.04 & 6.44 & 6.53 & 6.34 & -6.60 & 6.75 & 6.29 & -6.82 \\
\hline $\mathrm{B}_{2} \mathrm{O}_{3} *$ & 8.62 & 8.62 & 8.62 & 8.62 & 8.62 & $\mathrm{NC}$ & 8.50 & 8.50 & $\mathrm{NC}$ \\
\hline $\mathrm{CaO}$ & 2.73 & 2.85 & 2.76 & 1.86 & 2.49 & -8.87 & 2.69 & 2.86 & 6.19 \\
\hline $\mathrm{Cl}$ & 0.23 & 0.19 & 0.20 & 0.21 & 0.20 & NC & 0.23 & 0.18 & NC \\
\hline $\mathrm{Cr}_{2} \mathrm{O}_{3}$ & 0.60 & 0.77 & 0.70 & 0.71 & 0.73 & NC & 0.59 & 0.68 & NC \\
\hline $\mathrm{Cs} 2 \mathrm{O}$ & $\S$ & $<0.01$ & $<0.01$ & $<0.01$ & $<0.01$ & $\mathrm{NC}$ & $\S$ & $<0.01$ & $\mathrm{NC}$ \\
\hline $\mathrm{F}^{*}$ & 0.09 & 0.09 & 0.09 & 0.09 & 0.09 & NC & 0.09 & 0.09 & NC \\
\hline $\mathrm{Fe}_{2} \mathrm{O}_{3}$ & 0.20 & 0.17 & 0.27 & 0.23 & 0.22 & $\mathrm{NC}$ & 0.20 & 0.28 & $\mathrm{NC}$ \\
\hline I & $\S$ & 0.10 & 0.11 & 0.11 & 0.10 & NC & $\S$ & 0.09 & NC \\
\hline $\mathrm{K}_{2} \mathrm{O}$ & 5.61 & 6.28 & 5.87 & 5.89 & 6.02 & 7.18 & 5.75 & 5.89 & NC \\
\hline $\mathrm{Li}_{2} \mathrm{O}$ & $\S$ & NA & NA & NA & NA & NC & $\S$ & NA & $\mathrm{NC}$ \\
\hline $\mathrm{MgO}$ & 0.97 & 0.42 & 0.95 & 0.83 & 0.73 & NC & 0.95 & 0.82 & NC \\
\hline $\mathrm{MnO}$ & $\S$ & $<0.01$ & $<0.01$ & $<0.01$ & $<0.01$ & NC & $\S$ & $<0.01$ & NC \\
\hline $\mathrm{Na}_{2} \mathrm{O}$ & 20.52 & 21.55 & 19.83 & 22.65 & 21.34 & 4.02 & 21.00 & 20.36 & -3.07 \\
\hline $\mathrm{NiO}$ & 0.01 & 0.01 & 0.01 & 0.01 & 0.01 & NC & 0.01 & 0.01 & NC \\
\hline $\mathrm{P}_{2} \mathrm{O}_{5}$ & 0.14 & 0.20 & 0.20 & 0.20 & 0.20 & $\mathrm{NC}$ & 0.14 & 0.20 & NC \\
\hline $\mathrm{PbO}$ & 0.01 & 0.02 & 0.02 & 0.02 & 0.02 & NC & 0.01 & 0.01 & NC \\
\hline $\mathrm{SiO}_{2}$ & 41.43 & 41.02 & 41.37 & 40.26 & 40.88 & -1.33 & 40.85 & 40.80 & -0.12 \\
\hline $\mathrm{SnO}_{2}$ & 2.87 & 3.30 & 3.38 & 2.96 & 3.21 & 11.73 & 2.83 & 3.25 & 12.92 \\
\hline $\mathrm{SO}_{3}$ & $\S$ & 0.02 & 0.02 & 0.02 & 0.02 & NC & 0.33 & 0.25 & NC \\
\hline $\mathrm{TiO}_{2}$ & $\S$ & 0.10 & 0.12 & 0.12 & 0.11 & NC & $\S$ & 0.12 & NC \\
\hline $\mathrm{V}_{2} \mathrm{O}_{5}$ & $\S$ & $<0.01$ & 0.01 & $<0.01$ & 0.01 & NC & $\S$ & 0.02 & NC \\
\hline $\mathrm{ZnO}$ & 3.45 & 3.88 & 3.54 & 3.52 & 3.64 & 5.77 & 3.40 & 3.70 & 8.97 \\
\hline $\mathrm{ZrO}_{2}$ & 5.75 & 4.37 & 5.50 & 5.16 & 5.01 & -12.86 & 5.67 & 5.56 & -1.97 \\
\hline Sum & 100.00 & 100.00 & 100.00 & 100.00 & 100.00 & NC & 100.00 & 100.00 & NC \\
\hline
\end{tabular}

* - Target value

** - Target composition calculated based on actual proportion of meter feed residues after test

$\S$ - Not a target constituent

NA - Not analyzed

NC - Not calculated 
Table 3.1. Summary of Test A (Simulant: ORP S8AN105, Glass Formulation: ORPLA20) Conditions and Results.

\begin{tabular}{|c|c|c|c|c|c|}
\hline \multicolumn{2}{|c|}{ Test Segment } & A1 & A2 & A3 & A4 \\
\hline \multirow{3}{*}{ Time } & Feed Start & $\begin{array}{c}10 / 15 / 08 \\
7: 15\end{array}$ & $\begin{array}{c}10 / 15 / 08 \\
21: 05\end{array}$ & $\begin{array}{c}10 / 16 / 08 \\
10: 30\end{array}$ & $\begin{array}{c}10 / 17 / 08 \\
3: 00\end{array}$ \\
\hline & Feed End & $\begin{array}{c}10 / 15 / 08 \\
19: 38\end{array}$ & $\begin{array}{c}10 / 16 / 08 \\
9: 05\end{array}$ & $\begin{array}{c}10 / 16 / 08 \\
23: 30\end{array}$ & $\begin{array}{c}10 / 17 / 08 \\
16: 00\end{array}$ \\
\hline & Net Slurry Feeding (hr) & 12.4 & 12.0 & 13.0 & 13.0 \\
\hline \multirow{2}{*}{ Feed } & $\mathrm{wt} \% \mathrm{SO}_{3}$ as glass & 0.5 & 0.7 & 0.9 & 0.8 \\
\hline & Feed Used (kg) & 55.0 & 55.0 & 57.4 & 56.7 \\
\hline \multicolumn{2}{|c|}{ Average Production Rate $\left(\mathrm{kg} / \mathrm{m}^{2} /\right.$ day)* } & 2389 & 2462 & 2372 & 2344 \\
\hline \multicolumn{2}{|c|}{ Average Bubbling Rate (lpm) } & 3.3 & 3.5 & 3.9 & 3.5 \\
\hline \multirow{5}{*}{$\begin{array}{c}\text { Average } \\
\text { Temperatures } \\
\left({ }^{\circ} \mathrm{C}\right)\end{array}$} & Glass, 2" from floor & 1152 & 1153 & 1153 & 1151 \\
\hline & Glass, 4” from floor & 1122 & 1116 & 1126 & 1131 \\
\hline & Electrode & 1093 & 1101 & 1093 & 1100 \\
\hline & Plenum, thermowell & 469 & 471 & 492 & 476 \\
\hline & Plenum, exposed & 428 & 411 & 445 & 436 \\
\hline \multirow{3}{*}{ Product } & $\begin{array}{l}\text { Secondary Phases on Melt } \\
\text { Surface at Test End }\end{array}$ & No & No & Yes & Yes \\
\hline & Measured wt\% $\mathrm{SO}_{3}$ & 0.43 & 0.63 & 0.90 & 0.80 \\
\hline & $\begin{array}{l}\text { \% Feed Sulfur in Glass } \\
\text { Product }\end{array}$ & 86 & 90 & 100 & 100 \\
\hline \multirow{5}{*}{$\begin{array}{c}\text { Average } \\
\text { Concentrations } \\
\text { monitored in } \\
\text { stack exhaust by } \\
\text { FTIR (ppmv) }\end{array}$} & $\mathrm{N}_{2} \mathrm{O}$ & 68 & 68 & 67 & 65 \\
\hline & $\mathrm{NO}$ & 574 & 580 & 570 & 550 \\
\hline & $\mathrm{NO}_{2}$ & 86 & 86 & 81 & 81 \\
\hline & $\mathrm{CO}$ & 18 & 19 & 20 & 19 \\
\hline & $\mathrm{NH}_{3}$ & 25 & 33 & 29 & 27 \\
\hline
\end{tabular}

* - Glass production rates calculated from feed data 
The Catholic University of America Vitreous State Laboratory

Table 3.2. Summary of Test D (Simulant: ORP S8AN102, Glass Formulation: ORPLD6) Conditions and Results.

\begin{tabular}{|c|c|c|c|c|c|c|}
\hline \multicolumn{2}{|c|}{ Test Segment } & D1 & D2 & D3 & D4 & D5 \\
\hline \multirow{3}{*}{ Time } & Feed Start & $\begin{array}{c}10 / 21 / 08 \\
22: 20\end{array}$ & $\begin{array}{c}10 / 22 / 08 \\
12: 45\end{array}$ & $\begin{array}{c}10 / 23 / 08 \\
2: 28\end{array}$ & $\begin{array}{c}10 / 23 / 08 \\
19: 25\end{array}$ & $\begin{array}{c}1 / 15 / 09 \\
19: 40\end{array}$ \\
\hline & Feed End & $\begin{array}{c}10 / 22 / 08 \\
11: 30\end{array}$ & $\begin{array}{c}10 / 23 / 08 \\
1: 30\end{array}$ & $\begin{array}{c}10 / 23 / 08 \\
17: 30\end{array}$ & $\begin{array}{c}10 / 24 / 0 \\
7: 50\end{array}$ & $\begin{array}{c}1 / 16 / 09 \\
11: 26\end{array}$ \\
\hline & Net Slurry Feeding (hr) & 13.2 & 12.8 & 15.1\# & 12.4 & 15.8 \\
\hline \multirow{2}{*}{ Feed } & $\mathrm{wt} \% \mathrm{SO}_{3}$ as glass & 0.9 & 1.1 & 1.3 & 1.2 & 1.2 \\
\hline & Feed Used (kg) & 58.0 & 58.5 & 58.1 & 58.7 & 67.3 \\
\hline \multicolumn{2}{|c|}{ Average Production Rate $\left(\mathrm{kg} / \mathrm{m}^{2} / \text { day }\right)^{*}$} & 2486 & 2541 & 2177 & 2678 & 2410 \\
\hline \multicolumn{2}{|c|}{ Average Bubbling Rate (lpm) } & 4.0 & 4.1 & 2.9 & 4.1 & 2.1 \\
\hline \multirow{5}{*}{$\begin{array}{c}\text { Average } \\
\text { Temperatures } \\
\left({ }^{\circ} \mathrm{C}\right)\end{array}$} & Glass, 2" from floor & 1154 & 1151 & 1139 & 1152 & 1154 \\
\hline & Glass, 4” from floor & 1138 & 1136 & 1125 & 1139 & 1147 \\
\hline & Electrode & 1099 & 1097 & 1089 & 1100 & 1112 \\
\hline & Plenum, thermowell & 533 & 465 & 502 & 471 & 514 \\
\hline & Plenum, exposed & 502 & 407 & 442 & 422 & 431 \\
\hline \multirow{3}{*}{ Product } & $\begin{array}{l}\text { Secondary Phases on Melt } \\
\text { Surface at Test End }\end{array}$ & No & No & Yes & No & Yes \\
\hline & Measured wt $\% \mathrm{SO}_{3}$ & 0.90 & 1.10 & 1.30 & 1.26 & 1.25 \\
\hline & $\begin{array}{l}\text { \% Feed Sulfur in Glass } \\
\text { Product }\end{array}$ & 100 & 100 & 100 & 105 & 104 \\
\hline \multirow{5}{*}{$\begin{array}{c}\text { Average } \\
\text { Concentrations } \\
\text { monitored in } \\
\text { stack exhaust by } \\
\text { FTIR (ppmv) }\end{array}$} & $\mathrm{N}_{2} \mathrm{O}$ & 121 & 123 & 132 & 135 & 74 \\
\hline & NO & 632 & 657 & 699 & 725 & 621 \\
\hline & $\mathrm{NO}_{2}$ & 116 & 122 & 129 & 136 & 134 \\
\hline & $\mathrm{CO}$ & 36 & 34 & 40 & 40 & 30 \\
\hline & $\mathrm{NH}_{3}$ & 42 & 46 & 43 & 53 & 41 \\
\hline
\end{tabular}

* - Glass production rates calculated from feed data

\#- Net time reflects the total time interval including 130 minute down time.

NM - Not Measured. 
Table 3.3. Summary of Test F (Simulant: ORP S5AZ102, Glass Formulation: ORPLF7) Conditions and Results.

\begin{tabular}{|c|c|c|c|c|c|}
\hline \multicolumn{2}{|c|}{ Test Segment } & F1 & F2 & F3 & F4 \\
\hline \multirow{5}{*}{ Time } & \multirow{2}{*}{ Feed Start } & $1 / 5 / 09$ & $1 / 6 / 09$ & $1 / 7 / 09$ & $1 / 7 / 09$ \\
\hline & & $18: 28$ & $11: 22$ & $2: 40$ & $18: 55$ \\
\hline & \multirow{2}{*}{ Feed End } & $1 / 6 / 09$ & $1 / 7 / 09$ & $1 / 7 / 09$ & $1 / 8 / 09$ \\
\hline & & 8:00 & $1: 20$ & $16: 30$ & 9:00 \\
\hline & Net Slurry Feeding (hr) & 13.5 & 14.0 & 13.8 & 14.1 \\
\hline \multirow{2}{*}{ Feed } & $\mathrm{wt} \% \mathrm{SO}_{3}$ as glass & 1.6 & 1.4 & 1.2 & 0.8 \\
\hline & Feed Used (kg) & 52.9 & 52.5 & 52.2 & 50.7 \\
\hline \multicolumn{2}{|c|}{ Average Production Rate $\left(\mathrm{kg} / \mathrm{m}^{2} / \text { day }\right)^{*}$} & 2492 & 2396 & 2417 & 2297 \\
\hline \multicolumn{2}{|c|}{ Average Bubbling Rate (lpm) } & 1.8 & 2.2 & 2.0 & 2.6 \\
\hline \multirow{5}{*}{$\begin{array}{c}\text { Average } \\
\text { Temperatures } \\
\left({ }^{\circ} \mathrm{C}\right)\end{array}$} & Glass, 2” from floor & 1155 & 1151 & 1153 & 1152 \\
\hline & Glass, 4” from floor & 1147 & 1142 & 1143 & 1143 \\
\hline & Electrode & 1105 & 1104 & 1108 & 1092 \\
\hline & Plenum, thermowell & 516 & 513 & 494 & 468 \\
\hline & Plenum, exposed & 503 & 497 & 467 & 451 \\
\hline \multirow{3}{*}{ Product } & $\begin{array}{l}\text { Secondary Phases on Melt } \\
\text { Surface at Test End }\end{array}$ & Yes & Minor & No & No \\
\hline & Measured wt $\% \mathrm{SO}_{3}$ & 1.38 & 1.27 & 1.10 & 0.76 \\
\hline & $\begin{array}{l}\text { \% Feed Sulfur in Glass } \\
\text { Product }\end{array}$ & 86 & 91 & 92 & 95 \\
\hline \multirow{5}{*}{$\begin{array}{c}\text { Average } \\
\text { Concentrations } \\
\text { monitored in } \\
\text { stack exhaust by } \\
\text { FTIR (ppmv) }\end{array}$} & $\mathrm{N}_{2} \mathrm{O}$ & $<1$ & $<1$ & $<1$ & $<1$ \\
\hline & NO & 64 & 62 & 61 & 58 \\
\hline & $\mathrm{NO}_{2}$ & 8 & 10 & 10 & 10 \\
\hline & $\mathrm{CO}$ & $<1$ & $<1$ & $<1$ & $<1$ \\
\hline & $\mathrm{NH}_{3}$ & $<1$ & $<1$ & $<1$ & $<1$ \\
\hline
\end{tabular}

* - Glass production rates calculated from feed data

@ - Net time reflects the total time interval including 112 minute down time.

NM - Not Measured. 
Table 3.3. Summary of Test F (Simulant: ORP S5AZ102, Glass Formulation: ORPLF7) Conditions and Results (continued).

\begin{tabular}{|c|c|c|c|}
\hline \multicolumn{2}{|c|}{ Test Segment } & F5 & F6 \\
\hline \multirow{3}{*}{ Time } & Feed Start & $\begin{array}{c}1 / 12 / 09 \\
12: 01\end{array}$ & $\begin{array}{c}1 / 13 / 09 \\
2: 15\end{array}$ \\
\hline & Feed End & $\begin{array}{c}1 / 13 / 09 \\
0: 50\end{array}$ & $\begin{array}{c}1 / 13 / 09 \\
14: 45\end{array}$ \\
\hline & Net Slurry Feeding (hr) & 12.8 & 12.5 \\
\hline \multirow{2}{*}{ Feed } & wt $\% \mathrm{SO}_{3}$ as glass & 1.4 & 1.5 \\
\hline & Feed Used (kg) & 48.3 & 47.5 \\
\hline \multicolumn{2}{|c|}{ Average Production Rate $\left(\mathrm{kg} / \mathrm{m}^{2} / \text { day }\right)^{*}$} & 2411 & 2428 \\
\hline \multicolumn{2}{|c|}{ Average Bubbling Rate (lpm) } & 2.2 & 2.5 \\
\hline \multirow{5}{*}{$\begin{array}{c}\text { Average } \\
\text { Temperatures } \\
\left({ }^{\circ} \mathrm{C}\right)\end{array}$} & Glass, 2” from floor & 1154 & 1153 \\
\hline & Glass, 4” from floor & 1147 & 1146 \\
\hline & Electrode & 1117 & 1115 \\
\hline & Plenum, thermowell & 514 & 516 \\
\hline & Plenum, exposed & 496 & 505 \\
\hline \multirow{3}{*}{ Product } & $\begin{array}{l}\text { Secondary Phases on Melt } \\
\text { Surface at Test End }\end{array}$ & No & No \\
\hline & Measured wt\% $\mathrm{SO}_{3}$ & 1.20 & 1.35 \\
\hline & $\begin{array}{l}\text { \% Feed Sulfur in Glass } \\
\text { Product }\end{array}$ & 86 & 90 \\
\hline \multirow{5}{*}{$\begin{array}{c}\text { Average } \\
\text { Concentrations } \\
\text { monitored in } \\
\text { stack exhaust by } \\
\text { FTIR (ppmv) }\end{array}$} & $\mathrm{N}_{2} \mathrm{O}$ & $<1$ & $<1$ \\
\hline & $\mathrm{NO}$ & 63 & 67 \\
\hline & $\mathrm{NO}_{2}$ & 3 & 4 \\
\hline & $\mathrm{CO}$ & $<1$ & $<1$ \\
\hline & $\mathrm{NH}_{3}$ & $<1$ & $<1$ \\
\hline
\end{tabular}

* - Glass production rates calculated from feed data

@ - Net time reflects the total time interval including 66 minute down time. NC - Not Calculated. 
Table 3.4. Summary of Test G (Simulant: ORP S8AP101, Glass Formulation: ORPLG9) Conditions and Results.

\begin{tabular}{|c|c|c|c|c|}
\hline \multicolumn{2}{|c|}{ Test Segment } & G1 & G2 & G3 \\
\hline \multirow{3}{*}{ Time } & Feed Start & $\begin{array}{c}1 / 13 / 09 \\
15: 55\end{array}$ & $\begin{array}{c}1 / 14 / 09 \\
8: 45\end{array}$ & $\begin{array}{c}1 / 15 / 09 \\
3: 25\end{array}$ \\
\hline & Feed End & $\begin{array}{c}1 / 14 / 09 \\
6: 00\end{array}$ & $\begin{array}{c}1 / 15 / 09 \\
1: 30\end{array}$ & $\begin{array}{c}1 / 15 / 09 \\
17: 56\end{array}$ \\
\hline & Net Slurry Feeding (hr) & 14.1 & 16.8 & 14.5 \\
\hline \multirow{2}{*}{ Feed } & $\mathrm{wt} \% \mathrm{SO}_{3}$ as glass & 0.5 & 0.3 & 0.2 \\
\hline & Feed Used (kg) & 55.7 & 59.5 & 48.6 \\
\hline \multicolumn{2}{|c|}{ Average Production Rate $\left(\mathrm{kg} / \mathrm{m}^{2} / \text { day }\right)^{*}$} & 2298 & 2060 & 1950 \\
\hline \multicolumn{2}{|c|}{ Average Bubbling Rate (lpm) } & 2.0 & 2.3 & 2.2 \\
\hline \multirow{5}{*}{$\begin{array}{c}\text { Average } \\
\text { Temperatures } \\
\left({ }^{\circ} \mathrm{C}\right)\end{array}$} & Glass, 2” from floor & 1159 & 1154 & 1154 \\
\hline & Glass, 4” from floor & 1154 & 1150 & 1150 \\
\hline & Electrode & 1113 & 1103 & 1099 \\
\hline & Plenum, thermowell & 531 & 486 & 486 \\
\hline & Plenum, exposed & 502 & 429 & 402 \\
\hline \multirow{3}{*}{ Product } & $\begin{array}{l}\text { Secondary Phases on Melt } \\
\text { Surface at Test End }\end{array}$ & Yes & Yes & Yes \\
\hline & Measured wt $\% \mathrm{SO}_{3}$ & 0.58 & 0.34 & 0.21 \\
\hline & $\begin{array}{l}\text { \% Feed Sulfur in Glass } \\
\text { Product }\end{array}$ & 116 & 113 & 105 \\
\hline \multirow{5}{*}{$\begin{array}{c}\text { Average } \\
\text { Concentrations } \\
\text { monitored in } \\
\text { stack exhaust by } \\
\text { FTIR (ppmv) }\end{array}$} & $\mathrm{N}_{2} \mathrm{O}$ & 62 & 55 & 55 \\
\hline & NO & 518 & 437 & 426 \\
\hline & $\mathrm{NO}_{2}$ & 89 & 75 & 76 \\
\hline & $\mathrm{CO}$ & 13 & 8 & 8 \\
\hline & $\mathrm{NH}_{3}$ & 20 & 26 & 25 \\
\hline
\end{tabular}

* - Glass production rates calculated from feed data NM - Not Measured. 
Table 4.1. Listing of DM10 Glasses Discharged, Masses, Target Sulfur Contents and Analysis Performed.

\begin{tabular}{|c|c|c|c|c|c|c|c|}
\hline Test & Formulation & $\begin{array}{c}\text { Target } \\
\mathrm{SO}_{3}\end{array}$ & Date & Name & Analysis & $\begin{array}{c}\text { Mass } \\
\text { (kg) }\end{array}$ & $\begin{array}{c}\text { Cumulative } \\
\text { Mass (kg) }\end{array}$ \\
\hline \multirow{14}{*}{ A1 } & \multirow{44}{*}{ ORPLA20 } & \multirow{14}{*}{$0.5 \%$} & \multirow{16}{*}{$10 / 15 / 06$} & Y10-G-133A & - & - & - \\
\hline & & & & Y10-G-133B & - & - & - \\
\hline & & & & Y10-G-133C & XRF, DCP & 4.34 & 4.34 \\
\hline & & & & Y10-G-134A & - & - & - \\
\hline & & & & Y10-G-134B & - & - & - \\
\hline & & & & Y10-G-134C & XRF & 4.12 & 8.46 \\
\hline & & & & Y10-G-134D & - & - & - \\
\hline & & & & Y10-G-134E & - & - & - \\
\hline & & & & Y10-G-135A & XRF & 6.42 & 14.88 \\
\hline & & & & Y10-G-135B & - & - & - \\
\hline & & & & Y10-G-136A & - & - & - \\
\hline & & & & Y10-G-136B & XRF & 4.32 & 19.20 \\
\hline & & & & Y10-G-136C & - & - & - \\
\hline & & & & Y10-G-139A & XRF & 3.86 & 23.06 \\
\hline \multirow{9}{*}{ A2 } & & \multirow{9}{*}{$0.7 \%$} & & Y10-G-139B & - & - & - \\
\hline & & & & Y10-G-142A & XRF & 5.30 & 28.36 \\
\hline & & & \multirow{18}{*}{$10 / 16 / 08$} & Y10-G-142B & - & - & - \\
\hline & & & & Y10-G-143A & XRF & 5.28 & 33.64 \\
\hline & & & & Y10-G-143B & - & - & - \\
\hline & & & & Y10-G-143C & XRF & 4.66 & 38.30 \\
\hline & & & & Y10-G-146A & - & - & - \\
\hline & & & & Y10-G-146B & XRF & 4.36 & 42.66 \\
\hline & & & & Y10-G-146C & XRF, DCP & 2.36 & 45.02 \\
\hline \multirow{11}{*}{ A3 } & & \multirow{11}{*}{$0.9 \%$} & & Y10-G-147A & - & - & - \\
\hline & & & & Y10-G-147B & XRF & 4.92 & 49.94 \\
\hline & & & & Y10-G-147C & - & - & - \\
\hline & & & & Y10-G-147D & XRF & 5.36 & 55.30 \\
\hline & & & & Y10-G-149A & - & - & - \\
\hline & & & & Y10-G-149B & XRF & 3.62 & 58.92 \\
\hline & & & & Y10-G-149C & - & - & - \\
\hline & & & & Y10-G-153A & XRF & 4.20 & 63.12 \\
\hline & & & & Y10-G-153B & - & - & - \\
\hline & & & & Y10-G-153C & - & - & - \\
\hline & & & & Y10-G-153D & XRF & 7.48 & 70.60 \\
\hline \multirow{10}{*}{ A4 } & & \multirow{10}{*}{$0.8 \%$} & \multirow{10}{*}{$10 / 17 / 08$} & Y10-G-155A & - & - & - \\
\hline & & & & Y10-G-155B & XRF & 3.78 & 74.38 \\
\hline & & & & Y10-G-5A & - & - & - \\
\hline & & & & Z10-G-5B & XRF & 4.14 & 78.52 \\
\hline & & & & Z10-G-5C & - & - & - \\
\hline & & & & Z10-G-5D & XRF & 4.34 & 82.86 \\
\hline & & & & Z10-G-5E & - & - & - \\
\hline & & & & Z10-G-5F & XRF & 4.04 & 86.90 \\
\hline & & & & Z10-G-5G & - & - & - \\
\hline & & & & Z10-G-10A & XRF & 4.26 & 91.16 \\
\hline
\end{tabular}

- Empty data field 
Table 4.1. Listing of DM10 Glasses Discharged, Masses, Target Sulfur Contents and Analysis Performed (continued).

\begin{tabular}{|c|c|c|c|c|c|c|c|}
\hline Test & Formulation & $\begin{array}{c}\text { Target } \\
\mathrm{SO}_{3} \\
\end{array}$ & Date & Name & Analysis & $\begin{array}{c}\text { Mass } \\
(\mathrm{kg})\end{array}$ & $\begin{array}{c}\text { Cumulative } \\
\text { Mass (kg) }\end{array}$ \\
\hline \multirow{3}{*}{ A4 } & \multirow{3}{*}{ ORPLA20 } & \multirow{3}{*}{$0.8 \%$} & \multirow{3}{*}{ 10/17/08 } & Z10-G-10B & - & - & - \\
\hline & & & & Z10-G-11A & XRF & 5.72 & 96.88 \\
\hline & & & & Z10-G-16A & XRF & 1.02 & 97.90 \\
\hline \multirow{9}{*}{ B1 } & \multirow{39}{*}{ ORPLD6 } & \multirow{9}{*}{$0.9 \%$} & \begin{tabular}{|l|}
$10 / 21 / 08$ \\
\end{tabular} & Z10-G-29A & - & - & - \\
\hline & & & \multirow{16}{*}{$10 / 22 / 08$} & Z10-G-29B & XRF & 5.64 & 103.54 \\
\hline & & & & Z10-G-29C & - & - & - \\
\hline & & & & Z10-G-30A & XRF & 6.16 & 109.70 \\
\hline & & & & Z10-G-31A & - & - & - \\
\hline & & & & Z10-G-34A & XRF & 6.12 & 115.82 \\
\hline & & & & Z10-G-34B & - & - & - \\
\hline & & & & Z10-G-34C & XRF & 5.92 & 121.74 \\
\hline & & & & Z10-G-34D & XRF & 2.18 & 123.92 \\
\hline \multirow{10}{*}{ B2 } & & \multirow{10}{*}{$1.1 \%$} & & Z10-G-37A & - & - & - \\
\hline & & & & Z10-G-37B & XRF & 7.10 & 131.02 \\
\hline & & & & Z10-G-38A & - & - & - \\
\hline & & & & Z10-G-38B & XRF & 5.44 & 136.46 \\
\hline & & & & Z10-G-39A & - & - & - \\
\hline & & & & Z10-G-39B & XRF & 5.02 & 141.48 \\
\hline & & & & Z10-G-43A & - & - & - \\
\hline & & & & Z10-G-43B & XRF & 4.54 & 146.02 \\
\hline & & & \multirow{16}{*}{$10 / 23 / 08$} & Z10-G-43C & - & - & - \\
\hline & & & & Z10-G-44A & XRF & 4.02 & 150.04 \\
\hline \multirow{10}{*}{ B3 } & & \multirow{10}{*}{$1.3 \%$} & & Z10-G-45A & - & - & - \\
\hline & & & & Z10-G-46A & XRF & 4.82 & 154.86 \\
\hline & & & & Z10-G-46B & - & - & - \\
\hline & & & & Z10-G-46C & XRF & 4.80 & 159.66 \\
\hline & & & & Z10-G-50A & - & - & - \\
\hline & & & & Z10-G-50B & XRF & 5.40 & 165.06 \\
\hline & & & & Z10-G-51A & - & - & - \\
\hline & & & & Z10-G-51B & XRF & 5.12 & 170.18 \\
\hline & & & & Z10-G-51C & - & - & - \\
\hline & & & & Z10-G-51D & XRF & 5.68 & 175.86 \\
\hline \multirow{10}{*}{ B4 } & & \multirow{10}{*}{$1.2 \%$} & & Z10-G-54A & - & - & - \\
\hline & & & & Z10-G-54B & XRF & 5.00 & 180.86 \\
\hline & & & & Z10-G-54C & - & - & - \\
\hline & & & & Z10-G-58A & XRF & 4.36 & 185.22 \\
\hline & & & \multirow{6}{*}{$10 / 24 / 08$} & Z10-G-58B & - & - & - \\
\hline & & & & Z10-G-59A & XRF & 5.62 & 190.84 \\
\hline & & & & Z10-G-59B & - & - & - \\
\hline & & & & Z10-G-60A & XRF & 5.38 & 196.22 \\
\hline & & & & Z10-G-60B & - & - & - \\
\hline & & & & Z10-G-60C & XRF,DCP & 5.86 & 202.08 \\
\hline
\end{tabular}

- Empty data field 
Table 4.1. Listing of DM10 Glasses Discharged, Masses, Target Sulfur Contents and Analysis Performed (continued).

\begin{tabular}{|c|c|c|c|c|c|c|c|}
\hline Test & Formulation & $\begin{array}{c}\text { Target } \\
\mathrm{SO}_{3}\end{array}$ & Date & Name & Analysis & $\begin{array}{c}\text { Mass } \\
\text { (kg) }\end{array}$ & $\begin{array}{c}\text { Cumulative } \\
\text { Mass (kg) }\end{array}$ \\
\hline \multirow{15}{*}{ B5 } & \multirow{15}{*}{ ORPLD6 } & \multirow{15}{*}{$1.2 \%$} & \multirow{3}{*}{$1 / 15 / 09$} & $10 A-G-45 A$ & - & - & - \\
\hline & & & & 10A-G-45B & XRF & 4.44 & 206.52 \\
\hline & & & & 10A-G-51A & - & - & - \\
\hline & & & \multirow{12}{*}{$1 / 16 / 09$} & 10A-G-51B & XRF & 5.30 & 211.82 \\
\hline & & & & 10A-G-51C & - & - & - \\
\hline & & & & 10A-G-51D & XRF & 4.10 & 215.92 \\
\hline & & & & $10 A-G-52 A$ & - & - & - \\
\hline & & & & 10A-G-52B & XRF & 4.12 & 220.04 \\
\hline & & & & $10 \mathrm{~A}-\mathrm{G}-52 \mathrm{C}$ & - & - & - \\
\hline & & & & 10A-G-52D & XRF & 3.88 & 223.92 \\
\hline & & & & 10A-G-52E & - & - & - \\
\hline & & & & 10A-G-52F & XRF & 3.26 & 227.18 \\
\hline & & & & 10A-G-53A & - & - & - \\
\hline & & & & 10A-G-53B & $\mathrm{XRF}$ & 3.80 & 230.98 \\
\hline & & & & 10A-G-53C & XRF & 2.00 & 232.98 \\
\hline \multirow{13}{*}{ C1 } & \multirow{28}{*}{ ORPLF7 } & \multirow{13}{*}{$1.6 \%$} & \multirow{6}{*}{ 1/5/09 } & Z10-G-85A & - & - & - \\
\hline & & & & Z10-G-85B & - & - & - \\
\hline & & & & Z10-G-86A & XRF,DCP & 5.92 & 238.90 \\
\hline & & & & Z10-G-86B & - & - & - \\
\hline & & & & Z10-G-86C & XRF & 4.40 & 243.30 \\
\hline & & & & Z10-G-89A & - & - & - \\
\hline & & & \multirow{17}{*}{ 1/6/09 } & Z10-G-89B & XRF & 4.90 & 248.20 \\
\hline & & & & Z10-G-89C & - & - & - \\
\hline & & & & Z10-G-89D & XRF & 5.24 & 253.44 \\
\hline & & & & Z10-G-89E & - & - & - \\
\hline & & & & Z10-G-90A & XRF & 4.50 & 257.94 \\
\hline & & & & Z10-G-90B & XRF & 2.00 & 259.94 \\
\hline & & & & Z10-G-95A & - & - & - \\
\hline \multirow{11}{*}{$\mathrm{C} 2$} & & \multirow{11}{*}{$1.4 \%$} & & Z10-G-95B & XRF & 5.18 & 265.12 \\
\hline & & & & Z10-G-97A & - & - & - \\
\hline & & & & Z10-G-97B & XRF & 5.08 & 270.20 \\
\hline & & & & Z10-G-98A & - & - & - \\
\hline & & & & Z10-G-98B & XRF & 4.42 & 274.62 \\
\hline & & & & Z10-G-98C & - & - & - \\
\hline & & & & Z10-G-98D & XRF & 4.48 & 279.10 \\
\hline & & & & Z10-G-99A & - & - & - \\
\hline & & & & Z10-G-99B & XRF & 4.24 & 283.34 \\
\hline & & & & Z10-G-99C & - & - & - \\
\hline & & & \multirow{5}{*}{ 1/7/08 } & Z10-G-99D & XRF & 3.90 & 287.24 \\
\hline \multirow{4}{*}{ C3 } & & \multirow{4}{*}{$1.2 \%$} & & Z10-G-104A & - & - & - \\
\hline & & & & Z10-G-104B & XRF & 4.70 & 291.94 \\
\hline & & & & Z10-G-104C & - & - & - \\
\hline & & & & Z10-G-105A & XRF & 3.92 & 295.86 \\
\hline
\end{tabular}

- Empty data field 
Table 4.1. Listing of DM10 Glasses Discharged, Masses, Target Sulfur Contents and Analysis Performed (continued).

\begin{tabular}{|c|c|c|c|c|c|c|c|}
\hline Test & Formulation & $\begin{array}{c}\text { Target } \\
\mathrm{SO}_{3}\end{array}$ & Date & Name & Analysis & $\begin{array}{c}\text { Mass } \\
\text { (kg) }\end{array}$ & $\begin{array}{c}\text { Cumulative } \\
\text { Mass (kg) }\end{array}$ \\
\hline \multirow{9}{*}{ C3 } & \multirow{41}{*}{ ORPLF7 } & \multirow{9}{*}{$1.2 \%$} & \multirow{13}{*}{$1 / 7 / 08$} & Z10-G-105B & - & - & - \\
\hline & & & & Z10-G-105C & $\mathrm{XRF}$ & 3.48 & 299.34 \\
\hline & & & & Z10-G-107A & - & - & - \\
\hline & & & & Z10-G-107B & XRF & 3.28 & 302.62 \\
\hline & & & & Z10-G-110A & - & - & - \\
\hline & & & & Z10-G-110B & XRF & 3.90 & 306.52 \\
\hline & & & & Z10-G-111A & - & - & - \\
\hline & & & & Z10-G-111B & XRF & 3.04 & 309.56 \\
\hline & & & & Z10-G-111C & $\mathrm{XRF}$ & 2.28 & 311.84 \\
\hline \multirow{14}{*}{ C4 } & & \multirow{14}{*}{$0.8 \%$} & & Z10-G-113A & - & - & - \\
\hline & & & & Z10-G-113B & XRF & 5.30 & 317.14 \\
\hline & & & & Z10-G-115A & - & - & - \\
\hline & & & & Z10-G-115B & XRF & 4.26 & 321.40 \\
\hline & & & \multirow{10}{*}{$1 / 8 / 09$} & Z10-G-118A & - & - & - \\
\hline & & & & Z10-G-118B & XRF & 3.82 & 325.22 \\
\hline & & & & Z10-G-119A & - & - & - \\
\hline & & & & Z10-G-119B & XRF & 3.25 & 328.47 \\
\hline & & & & Z10-G-119C & - & - & - \\
\hline & & & & Z10-G-121A & XRF & 3.36 & 331.83 \\
\hline & & & & Z10-G-121B & - & - & - \\
\hline & & & & Z10-G-121C & XRF & 3.42 & 335.25 \\
\hline & & & & Z10-G-122A & - & - & - \\
\hline & & & & Z10-G-122B & XRF & 2.38 & 337.63 \\
\hline \multirow{9}{*}{ C5 } & & \multirow{9}{*}{$1.4 \%$} & \multirow{8}{*}{$1 / 12 / 09$} & Z10-G-141A & - & - & - \\
\hline & & & & Z10-G-141B & XRF, DCP & 5.42 & 343.05 \\
\hline & & & & Z10-G-141C & - & - & - \\
\hline & & & & Z10-G-142A & XRF & 4.86 & 347.91 \\
\hline & & & & Z10-G-142B & - & - & - \\
\hline & & & & Z10-G-142C & XRF & 6.06 & 353.97 \\
\hline & & & & Z10-G-142D & - & - & - \\
\hline & & & & Z10-G-143A & XRF & 4.48 & 358.45 \\
\hline & & & \multirow{12}{*}{ 1/13/09 } & Z10-G-143B & XRF & 2.08 & 360.53 \\
\hline \multirow{9}{*}{ C6 } & & \multirow{9}{*}{$1.5 \%$} & & Z10-G-146A & - & - & - \\
\hline & & & & Z10-G-146B & XRF & 5.50 & 366.03 \\
\hline & & & & Z10-G-148A & - & - & - \\
\hline & & & & Z10-G-148B & XRF & 4.68 & 370.71 \\
\hline & & & & Z10-G-148C & - & - & - \\
\hline & & & & Z10-G-149A & XRF & 5.62 & 376.33 \\
\hline & & & & Z10-G-149B & - & - & - \\
\hline & & & & Z10-G-153A & XRF & 5.92 & 382.25 \\
\hline & & & & Z10-G-153B & $\mathrm{XRF}$ & 5.38 & 387.63 \\
\hline \multirow{2}{*}{ D1 } & \multirow{2}{*}{ ORPLG9 } & \multirow{2}{*}{$0.5 \%$} & & 10A-G-9A & - & - & - \\
\hline & & & & 10A-G-9B & XRF & 4.08 & 391.71 \\
\hline
\end{tabular}

- Empty data field 
Table 4.1. Listing of DM10 Glasses Discharged, Masses, Target Sulfur Contents and Analysis Performed (continued).

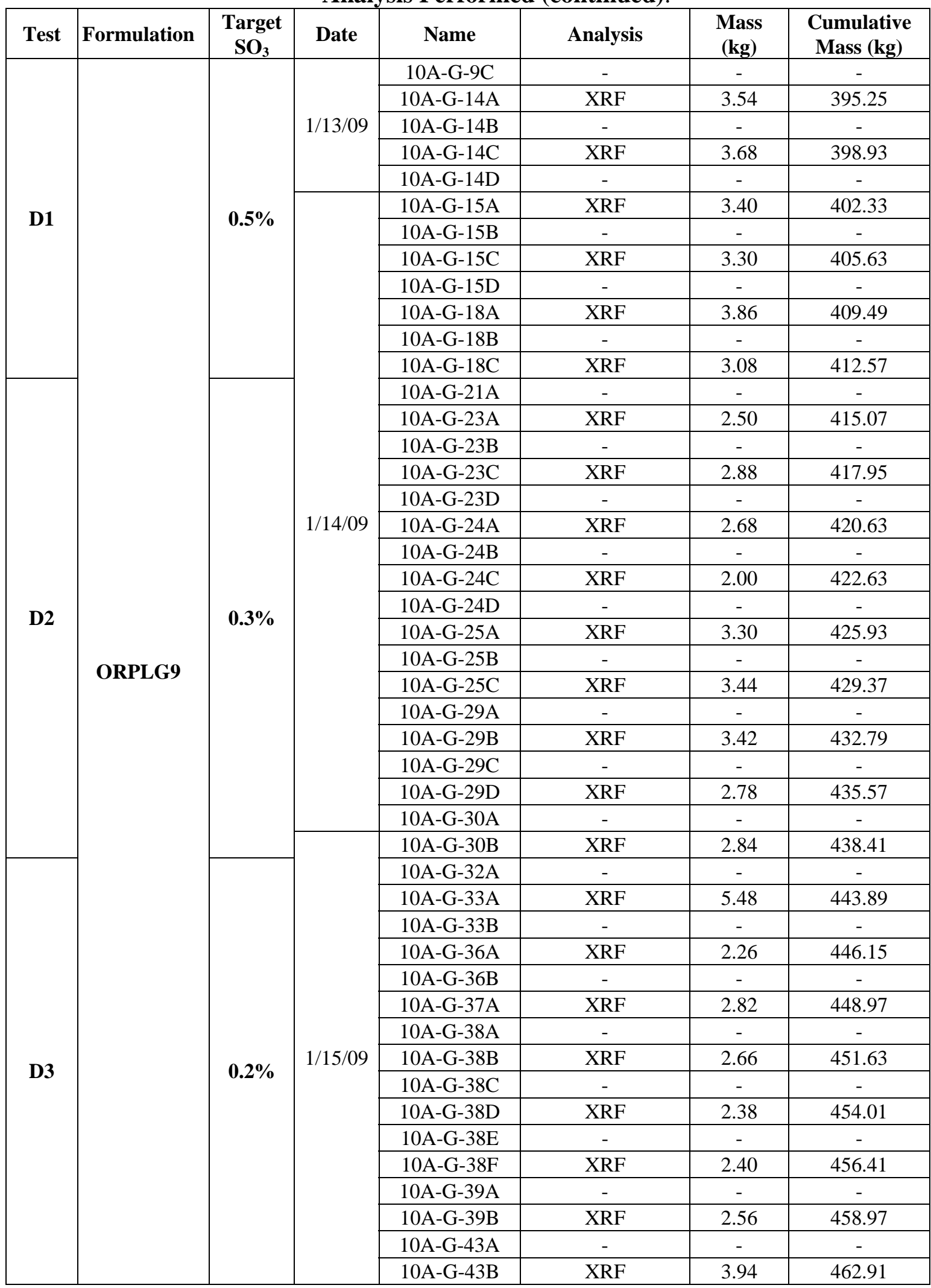

- Empty data field 
The Catholic University of America Vitreous State Laboratory

Table 4.2. XRF Analyzed Compositions for DM10 Discharged Glass Samples (wt\%).

\begin{tabular}{|c|c|c|c|c|c|c|c|c|c|c|}
\hline Formulation & \multicolumn{10}{|c|}{ ORPLA20 } \\
\hline Test & \multicolumn{6}{|c|}{ A1 } & \multicolumn{4}{|c|}{ A2 } \\
\hline Target $\mathrm{SO}_{3}$ & \multicolumn{6}{|c|}{$0.5 \%$} & \multicolumn{4}{|c|}{$0.7 \%$} \\
\hline Glass (kg) & - & 4.34 & 8.46 & 14.88 & 19.20 & 23.06 & - & 28.36 & 33.64 & 38.30 \\
\hline Constituent & Target & $\begin{array}{c}\text { Y10-G- } \\
133 C\end{array}$ & \begin{tabular}{|c|} 
Y10-G- \\
$134 \mathrm{C}$
\end{tabular} & $\begin{array}{c}\text { Y10-G- } \\
135 A\end{array}$ & $\begin{array}{c}\text { Y10-G- } \\
136 B\end{array}$ & $\begin{array}{c}\text { Y10-G- } \\
139 A\end{array}$ & Target & $\begin{array}{c}\text { Y10-G- } \\
142 A\end{array}$ & $\begin{array}{c}\text { Y10-G- } \\
143 A\end{array}$ & $\begin{array}{c}\text { Y10-G- } \\
143 C\end{array}$ \\
\hline $\mathrm{Al}_{2} \mathrm{O}_{3}$ & 6.67 & 8.35 & 7.97 & 7.57 & 7.16 & 7.14 & 6.65 & 6.92 & 6.79 & 6.66 \\
\hline $\mathrm{B}_{2} \mathrm{O}_{3}$ & 8.76 & 7.93 & 8.21 & 8.47 & 8.57 & 8.63 & 8.74 & 8.68 & 8.70 & 8.72 \\
\hline $\mathrm{CaO}$ & 3.33 & 2.75 & 3.04 & 3.20 & 3.31 & 3.35 & 3.32 & 3.45 & 3.54 & 3.51 \\
\hline $\mathrm{Cl}$ & 0.67 & 0.31 & 0.35 & 0.40 & 0.46 & 0.46 & 0.67 & 0.49 & 0.49 & 0.48 \\
\hline $\mathrm{Cr}_{2} \mathrm{O}_{3} *$ & 0.50 & 0.42 & 0.56 & 0.61 & 0.65 & 0.66 & 0.50 & 0.73 & 0.72 & 0.75 \\
\hline $\mathrm{Cs}_{2} \mathrm{O}$ & $\S$ & 0.11 & 0.06 & 0.03 & 0.01 & $<0.01$ & $\S$ & $<0.01$ & $<0.01$ & $<0.01$ \\
\hline $\mathrm{F}$ & $\S$ & NA & NA & NA & NA & NA & $\S$ & NA & NA & NA \\
\hline $\mathrm{Fe}_{2} \mathrm{O}_{3}$ & 0.19 & 3.12 & 2.20 & 1.48 & 0.95 & 0.71 & 0.19 & 0.59 & 0.47 & 0.37 \\
\hline $\mathrm{I}$ & $\S$ & 0.06 & 0.07 & 0.09 & 0.09 & 0.09 & $\S$ & 0.13 & 0.12 & 0.11 \\
\hline K2O & 0.54 & 0.52 & 0.54 & 0.53 & 0.54 & 0.53 & 0.53 & 0.56 & 0.54 & 0.55 \\
\hline $\mathrm{Li}_{2} \mathrm{O}^{*}$ & $\S$ & 0.13 & 0.09 & 0.05 & 0.03 & 0.02 & $\S$ & 0.01 & 0.01 & $<0.01$ \\
\hline $\mathrm{MgO}$ & 0.93 & 1.51 & 1.36 & 1.11 & 0.98 & 0.93 & 0.92 & 0.78 & 0.75 & 0.98 \\
\hline $\mathrm{MnO}$ & $\S$ & 0.02 & 0.01 & 0.01 & 0.01 & 0.00 & $\S$ & $<0.01$ & 0.01 & 0.01 \\
\hline $\mathrm{Na}_{2} \mathrm{O}$ & 24.00 & 20.65 & 21.49 & 22.62 & 23.34 & 22.87 & 24.00 & 23.51 & 23.11 & 23.78 \\
\hline $\mathrm{NiO}$ & $\S$ & 0.46 & 0.35 & 0.26 & 0.18 & 0.14 & $\S$ & 0.14 & 0.13 & 0.14 \\
\hline $\mathrm{P}_{2} \mathrm{O}_{5}$ & $\S$ & 0.34 & 0.23 & 0.15 & 0.10 & 0.08 & $\S$ & 0.07 & 0.05 & 0.04 \\
\hline $\mathrm{PbO}$ & $\S$ & $<0.01$ & 0.01 & 0.01 & $<0.01$ & $<0.01$ & $\S$ & 0.01 & 0.01 & 0.01 \\
\hline $\mathrm{SiO}_{2}$ & 42.44 & 43.68 & 42.86 & 42.53 & 42.75 & 43.82 & 42.33 & 42.42 & 42.19 & 41.98 \\
\hline $\mathrm{SnO}_{2}$ & 2.75 & 1.53 & 2.20 & 2.52 & 2.60 & 2.60 & 2.74 & 3.17 & 3.40 & 3.07 \\
\hline $\mathrm{SO}_{3}$ & 0.50 & 0.31 & 0.34 & 0.38 & 0.41 & 0.43 & 0.70 & 0.45 & 0.53 & 0.56 \\
\hline $\mathrm{TiO}_{2}$ & $\S$ & 0.40 & 0.28 & 0.19 & 0.12 & 0.10 & $\S$ & 0.08 & 0.07 & 0.05 \\
\hline $\mathrm{V}_{2} \mathrm{O}_{5}$ & $\S$ & 0.42 & 0.27 & 0.17 & 0.10 & 0.07 & $\S$ & 0.05 & 0.03 & 0.01 \\
\hline $\mathrm{ZnO}$ & 2.75 & 2.41 & 2.59 & 2.66 & 2.67 & 2.61 & 2.74 & 2.82 & 2.92 & 2.84 \\
\hline $\mathrm{ZrO}_{2}$ & 5.97 & 4.59 & 4.91 & 4.92 & 4.95 & 4.77 & 5.96 & 4.95 & 5.43 & 5.40 \\
\hline Sum & 100.00 & 100.00 & 100.00 & 100.00 & 100.00 & 100.00 & 100.00 & 100.00 & 100.00 & 100.00 \\
\hline
\end{tabular}

* - Target values calculated based on simple well-stirred tank model using DCP-AES analyzed boron and lithium concentrations in the first discharged glass sample

$\S$ - Not a target constituent

NA - not analyzed by XRF

“_“ sign for empty data field 
The Catholic University of America Vitreous State Laboratory

Table 4.2. XRF Analyzed Compositions for DM10 Discharged Glass Samples (wt\%) (continued).

\begin{tabular}{|c|c|c|c|c|c|c|c|c|c|c|c|}
\hline Formulation & \multicolumn{11}{|c|}{ ORPLA20 } \\
\hline Test & \multicolumn{3}{|c|}{ A2 } & \multicolumn{6}{|c|}{ A3 } & \multicolumn{2}{|c|}{ A4 } \\
\hline Target $\mathrm{SO}_{3}$ & \multicolumn{3}{|c|}{$0.7 \%$} & \multicolumn{6}{|c|}{$0.9 \%$} & \multicolumn{2}{|c|}{$0.8 \%$} \\
\hline Glass (kg) & - & 42.66 & 45.02 & - & 49.94 & 55.30 & 58.92 & 63.12 & 70.60 & - & 74.38 \\
\hline Constituent & Target & $\begin{array}{c}\text { Y10-G- } \\
146 B\end{array}$ & $\begin{array}{c}\text { Y10-G- } \\
146 \mathrm{C}\end{array}$ & Target & $\begin{array}{c}\text { Y10-G- } \\
147 \mathrm{~B}\end{array}$ & $\begin{array}{c}\text { Y10-G- } \\
\text { 147D }\end{array}$ & $\begin{array}{c}\text { Y10-G } \\
\text { 149B }\end{array}$ & $\begin{array}{c}\text { Y10-G } \\
\text { 153A }\end{array}$ & $\begin{array}{c}\text { Y10-G- } \\
153 D\end{array}$ & Target & $\begin{array}{c}\text { Y10-G- } \\
\text { 155B }\end{array}$ \\
\hline $\mathrm{Al}_{2} \mathrm{O}_{3}$ & 6.65 & 6.59 & 6.72 & 6.64 & 6.82 & 6.70 & 6.66 & 6.62 & 6.52 & 6.64 & 6.55 \\
\hline $\mathrm{B}_{2} \mathrm{O}_{3}$ & 8.74 & 8.72 & 8.73 & 8.72 & 8.72 & 8.72 & 8.72 & 8.72 & 8.72 & 8.73 & 8.72 \\
\hline $\mathrm{CaO}$ & 3.32 & 3.56 & 3.56 & 3.31 & 3.45 & 3.39 & 3.42 & 3.38 & 3.50 & 3.32 & 3.48 \\
\hline $\mathrm{Cl}$ & 0.67 & 0.50 & 0.53 & 0.67 & 0.46 & 0.47 & 0.49 & 0.49 & 0.54 & 0.67 & 0.45 \\
\hline $\mathrm{Cr}_{2} \mathrm{O}_{3} *$ & 0.50 & 0.72 & 0.73 & 0.50 & 0.68 & 0.67 & 0.68 & 0.67 & 0.76 & 0.50 & 0.68 \\
\hline $\mathrm{Cs}_{2} \mathrm{O}$ & $\S$ & $<0.01$ & $<0.01$ & $\S$ & $<0.01$ & $<0.01$ & $<0.01$ & $<0.01$ & $<0.01$ & $\S$ & $<0.01$ \\
\hline $\mathrm{F}$ & $\S$ & NA & NA & $\S$ & NA & NA & NA & NA & NA & $\S$ & NA \\
\hline $\mathrm{Fe}_{2} \mathrm{O}_{3}$ & 0.19 & 0.34 & 0.35 & 0.19 & 0.28 & 0.27 & 0.27 & 0.29 & 0.28 & 0.19 & 0.28 \\
\hline $\mathrm{I}$ & $\S$ & 0.10 & 0.10 & $\S$ & 0.09 & 0.11 & 0.10 & 0.10 & 0.10 & $\S$ & 0.10 \\
\hline $\mathrm{K} 2 \mathrm{O}$ & 0.53 & 0.55 & 0.56 & 0.53 & 0.53 & 0.55 & 0.53 & 0.53 & 0.56 & 0.53 & 0.54 \\
\hline $\mathrm{Li}_{2} \mathrm{O}^{*}$ & $\S$ & $<0.01$ & $<0.01$ & $\S$ & $<0.01$ & $<0.01$ & $<0.01$ & $<0.01$ & $<0.01$ & $\S$ & $<0.01$ \\
\hline $\mathrm{MgO}$ & 0.92 & 1.00 & 0.95 & 0.92 & 0.82 & 0.99 & 0.99 & 1.14 & 0.99 & 0.92 & 1.10 \\
\hline $\mathrm{MnO}$ & $\S$ & 0.01 & 0.01 & & 0.01 & 0.01 & 0.01 & 0.01 & 0.01 & $\S$ & 0.01 \\
\hline $\mathrm{Na}_{2} \mathrm{O}$ & 24.00 & 22.61 & 23.09 & 24.00 & 23.72 & 23.95 & 23.27 & 23.10 & 23.54 & 24.00 & 23.75 \\
\hline $\mathrm{NiO}$ & $\S$ & 0.09 & 0.09 & $\S$ & 0.08 & 0.07 & 0.07 & 0.07 & 0.06 & $\S$ & 0.10 \\
\hline $\mathrm{P}_{2} \mathrm{O}_{5}$ & $\S$ & 0.03 & 0.04 & $\S$ & 0.03 & 0.03 & 0.03 & 0.03 & 0.02 & $\S$ & 0.02 \\
\hline $\mathrm{PbO}$ & $\S$ & 0.01 & 0.01 & $\S$ & 0.01 & 0.01 & 0.01 & $<0.01$ & 0.01 & $\S$ & $<0.01$ \\
\hline $\mathrm{SiO}_{2}$ & 42.33 & 42.62 & 42.78 & 42.22 & 42.98 & 42.46 & 42.84 & 42.83 & 41.63 & 42.28 & 42.38 \\
\hline $\mathrm{SnO}_{2}$ & 2.74 & 3.22 & 2.87 & 2.73 & 2.81 & 2.94 & 2.96 & 2.98 & 3.17 & 2.73 & 2.97 \\
\hline $\mathrm{SO}_{3}$ & 0.70 & 0.63 & 0.61 & 0.90 & 0.69 & 0.73 & 0.84 & 0.82 & 1.04 & 0.80 & 0.76 \\
\hline $\mathrm{TiO}_{2}$ & $\S$ & 0.05 & 0.05 & $\S$ & 0.04 & 0.03 & 0.04 & 0.04 & 0.04 & $\S$ & 0.04 \\
\hline $\mathrm{V}_{2} \mathrm{O}_{5}$ & $\S$ & 0.01 & 0.01 & $\S$ & $<0.01$ & $<0.01$ & $<0.01$ & $<0.01$ & $<0.01$ & $\S$ & $<0.01$ \\
\hline $\mathrm{ZnO}$ & 2.74 & 2.91 & 2.87 & 2.73 & 2.74 & 2.69 & 2.71 & 2.72 & 2.89 & 2.73 & 2.78 \\
\hline $\mathrm{ZrO}_{2}$ & 5.96 & 5.71 & 5.35 & 5.94 & 5.06 & 5.23 & 5.34 & 5.47 & 5.61 & 5.95 & 5.30 \\
\hline Sum & \begin{tabular}{|l|l}
100.00 \\
\end{tabular} & 100.00 & 100.00 & 100.00 & 100.00 & 100.00 & 100.00 & \begin{tabular}{|l|l|}
100.00 \\
\end{tabular} & 100.00 & 100.00 & \begin{tabular}{|l|l}
100.00 \\
\end{tabular} \\
\hline
\end{tabular}

* - Target values calculated based on simple well-stirred tank model using DCP-AES analyzed boron and lithium concentrations in the first discharged glass sample

$\S$ - Not a target constituent

NA - not analyzed by XRF

“_“ sign for empty data field 
The Catholic University of America Vitreous State Laboratory

Table 4.2. XRF Analyzed Compositions for DM10 Discharged Glass Samples (wt\%) (continued).

\begin{tabular}{|c|c|c|c|c|c|c|c|c|c|c|c|}
\hline Formulation & \multicolumn{7}{|c|}{ ORPLA20 } & \multicolumn{4}{|c|}{ ORPLD6 } \\
\hline Test & \multicolumn{7}{|c|}{ A4 } & \multicolumn{4}{|c|}{ D1 } \\
\hline Target $\mathrm{SO}_{3}$ & \multicolumn{7}{|c|}{$0.8 \%$} & \multicolumn{4}{|c|}{$0.9 \%$} \\
\hline Glass (kg) & - & 78.52 & 82.86 & 86.90 & 91.16 & 96.88 & 97.90 & - & 103.54 & \begin{tabular}{|l|}
109.70 \\
\end{tabular} & 115.82 \\
\hline Constituent & Target & \begin{tabular}{|c|} 
Z10-G- \\
$5 B$
\end{tabular} & $\begin{array}{c}\text { Z10-G- } \\
5 \mathrm{D}\end{array}$ & $\begin{array}{c}\text { Z10-G- } \\
5 \mathrm{~F}\end{array}$ & \begin{tabular}{|c|} 
Z10-G- \\
$10 \mathrm{~A}$
\end{tabular} & $\begin{array}{c}\text { Z10-G- } \\
11 \mathrm{~A}\end{array}$ & $\begin{array}{c}\text { Z10-G- } \\
16 \mathrm{~A}\end{array}$ & Target & $\begin{array}{c}\text { Z10-G- } \\
\text { 29B }\end{array}$ & \begin{tabular}{|c|} 
Z10-G- \\
$30 A$
\end{tabular} & $\begin{array}{c}\mathrm{Z} 10-\mathrm{G} \\
34 \mathrm{~A}\end{array}$ \\
\hline $\mathrm{Al}_{2} \mathrm{O}_{3}$ & 6.64 & 6.57 & 6.48 & 6.52 & 6.57 & 6.47 & 6.76 & 10.13 & 7.93 & 8.53 & 8.78 \\
\hline $\mathrm{B}_{2} \mathrm{O}_{3}$ & 8.73 & 8.72 & 8.72 & 8.73 & 8.73 & 8.73 & 8.73 & 9.89 & 9.23 & 9.53 & 9.70 \\
\hline $\mathrm{CaO}$ & 3.32 & 3.56 & 3.52 & 3.45 & 3.55 & 3.60 & 3.56 & 7.92 & 5.40 & 6.65 & 7.39 \\
\hline $\mathrm{Cl}$ & 0.67 & 0.49 & 0.49 & 0.48 & 0.51 & 0.54 & 0.10 & 0.35 & 0.17 & 0.22 & 0.22 \\
\hline $\mathrm{Cr}_{2} \mathrm{O}_{3} *$ & 0.50 & 0.72 & 0.71 & 0.68 & 0.70 & 0.80 & 1.16 & 0.50 & 0.76 & 0.76 & 0.80 \\
\hline $\mathrm{Cs}_{2} \mathrm{O}$ & $\S$ & $<0.01$ & $<0.01$ & $<0.01$ & $<0.01$ & $<0.01$ & $<0.01$ & $\S$ & $<0.01$ & $<0.01$ & $<0.01$ \\
\hline F & $\S$ & NA & NA & NA & NA & NA & NA & 0.18 & NA & NA & NA \\
\hline $\mathrm{Fe}_{2} \mathrm{O}_{3}$ & 0.19 & 0.30 & 0.31 & 0.27 & 0.29 & 0.28 & 0.53 & 0.28 & 0.44 & 0.43 & 0.38 \\
\hline I & $\S$ & 0.10 & 0.12 & 0.11 & 0.10 & 0.10 & 0.10 & $\S$ & 0.07 & 0.03 & 0.02 \\
\hline $\mathrm{K} 2 \mathrm{O}$ & 0.53 & 0.57 & 0.54 & 0.54 & 0.55 & 0.57 & 0.53 & 0.17 & 0.37 & 0.28 & 0.25 \\
\hline $\mathrm{Li}_{2} \mathrm{O}^{*}$ & $\S$ & $<0.01$ & $<0.01$ & $<0.01$ & $<0.01$ & $<0.01$ & $<0.01$ & $\S$ & $<0.01$ & $<0.01$ & $<0.01$ \\
\hline $\mathrm{MgO}$ & 0.92 & 0.97 & 1.00 & 1.09 & 1.03 & 0.88 & 0.96 & $\S$ & 0.95 & 0.86 & 0.85 \\
\hline $\mathrm{MnO}$ & $\S$ & $<0.01$ & 0.01 & 0.01 & 0.01 & 0.01 & 0.01 & $\S$ & $<0.01$ & 0.01 & 0.01 \\
\hline $\mathrm{Na}_{2} \mathrm{O}$ & 24.00 & 22.91 & 23.19 & 23.78 & 22.64 & 23.14 & 21.93 & 22.00 & 22.97 & 23.22 & 23.32 \\
\hline $\mathrm{NiO}$ & $\S$ & 0.09 & 0.07 & 0.06 & 0.06 & 0.06 & 0.26 & 0.04 & 0.23 & 0.19 & 0.19 \\
\hline $\mathrm{P}_{2} \mathrm{O}_{5}$ & $\S$ & 0.01 & 0.02 & 0.02 & $<0.01$ & 0.03 & 0.05 & 0.30 & 0.18 & 0.26 & 0.32 \\
\hline $\mathrm{PbO}$ & $\S$ & 0.01 & 0.01 & 0.01 & 0.01 & 0.01 & 0.01 & 0.01 & 0.01 & 0.02 & 0.02 \\
\hline $\mathrm{SiO}_{2}$ & 42.28 & 42.18 & 42.06 & 41.82 & 42.61 & 41.58 & 42.40 & 37.38 & 40.22 & 38.24 & 37.39 \\
\hline $\mathrm{SnO}_{2}$ & 2.73 & 3.27 & 3.31 & 3.17 & 3.22 & 3.42 & 3.30 & $\S$ & 1.88 & 0.99 & 0.50 \\
\hline $\mathrm{SO}_{3}$ & 0.80 & 0.82 & 0.83 & 0.79 & 0.79 & 0.93 & 1.13 & 0.90 & 0.76 & 0.80 & 0.85 \\
\hline $\mathrm{TiO}_{2}$ & $\S$ & 0.04 & 0.04 & 0.04 & 0.03 & 0.04 & 0.06 & $\S$ & 0.11 & 0.15 & 0.17 \\
\hline $\mathrm{V}_{2} \mathrm{O}_{5}$ & $\S$ & $<0.01$ & $<0.01$ & $<0.01$ & $<0.01$ & $<0.01$ & 0.01 & 1.97 & 0.97 & 1.55 & 1.87 \\
\hline $\mathrm{ZnO}$ & 2.73 & 2.94 & 2.88 & 2.83 & 2.89 & 2.99 & 2.89 & 2.97 & 2.86 & 2.99 & 3.06 \\
\hline $\mathrm{ZrO}_{2}$ & 5.95 & 5.72 & 5.69 & 5.60 & 5.73 & 5.83 & 5.51 & 4.00 & 4.50 & 4.28 & 3.91 \\
\hline Sum & 100.00 & 100.00 & 100.00 & 100.00 & 100.00 & 100.00 & 100.00 & 100.00 & 100.00 & 100.00 & 100.00 \\
\hline
\end{tabular}

* - Target values calculated based on simple well-stirred tank model using DCP-AES analyzed boron and lithium concentrations in the first discharged glass sample

$\S$ - Not a target constituent

NA - not analyzed by XRF

“_“ sign for empty data field 
The Catholic University of America Vitreous State Laboratory

Table 4.2. XRF Analyzed Compositions for DM10 Discharged Glass Samples (wt\%), (continued).

\begin{tabular}{|c|c|c|c|c|c|c|c|c|c|c|c|}
\hline Formulation & \multicolumn{11}{|c|}{ ORPLD6 } \\
\hline Test & \multicolumn{3}{|c|}{ D1 } & \multicolumn{6}{|c|}{ D2 } & \multicolumn{2}{|c|}{ D3 } \\
\hline Target $\mathrm{SO}_{3}$ & \multicolumn{3}{|c|}{$0.9 \%$} & \multicolumn{6}{|c|}{$1.1 \%$} & \multicolumn{2}{|c|}{$1.3 \%$} \\
\hline Glass (kg) & - & 121.74 & 123.92 & - & 131.02 & 136.46 & 141.48 & 146.02 & 150.04 & - & 154.86 \\
\hline Constituent & Target & $\begin{array}{c}\text { Z10-G- } \\
34 \mathrm{C}\end{array}$ & $\begin{array}{c}\text { Z10-G- } \\
\text { 34D }\end{array}$ & Target & $\begin{array}{c}\text { Z10-G- } \\
\text { 37B }\end{array}$ & $\begin{array}{c}\text { Z10-G- } \\
\text { 38B }\end{array}$ & $\begin{array}{c}\text { Z10-G- } \\
\text { 39B }\end{array}$ & $\begin{array}{c}\text { Z10-G- } \\
43 \mathrm{~B}\end{array}$ & $\begin{array}{c}\text { Z10-G- } \\
44 \mathrm{~A}\end{array}$ & Target & $\begin{array}{c}\mathrm{Z} 10-\mathrm{G} \\
46 \mathrm{~A}\end{array}$ \\
\hline $\mathrm{Al}_{2} \mathrm{O}_{3}$ & 10.13 & 8.78 & 9.04 & 10.11 & 9.28 & 9.37 & 9.18 & 8.70 & 8.64 & 10.08 & 9.08 \\
\hline $\mathrm{B}_{2} \mathrm{O}_{3}$ & 9.89 & 9.78 & 9.80 & 9.86 & 9.83 & 9.85 & 9.85 & 9.86 & 9.86 & 9.84 & 9.85 \\
\hline $\mathrm{CaO}$ & 7.92 & 7.88 & 7.71 & 7.90 & 7.83 & 7.60 & 7.59 & 8.23 & 8.13 & 7.88 & 8.03 \\
\hline $\mathrm{Cl}$ & 0.35 & 0.28 & 0.28 & 0.35 & 0.29 & 0.27 & 0.29 & 0.31 & 0.31 & 0.35 & 0.27 \\
\hline $\mathrm{Cr}_{2} \mathrm{O}_{3} *$ & 0.50 & 0.85 & 0.82 & 0.50 & 0.78 & 0.71 & 0.71 & 0.82 & 0.81 & 0.50 & 0.76 \\
\hline $\mathrm{Cs}_{2} \mathrm{O}$ & $\S$ & $<0.01$ & $<0.01$ & $\S$ & $<0.01$ & $<0.01$ & $<0.01$ & $<0.01$ & $<0.01$ & $\S$ & $<0.01$ \\
\hline $\mathrm{F}$ & 0.18 & NA & NA & 0.18 & NA & NA & NA & NA & NA & 0.18 & NA \\
\hline $\mathrm{Fe}_{2} \mathrm{O}_{3}$ & 0.28 & 0.40 & 0.42 & 0.28 & 0.38 & 0.36 & 0.30 & 0.31 & 0.28 & 0.28 & 0.32 \\
\hline I & $\S$ & 0.01 & $<0.01$ & $\S$ & $<0.01$ & $<0.01$ & $<0.01$ & $<0.01$ & $<0.01$ & $\S$ & $<0.01$ \\
\hline $\mathrm{K} 2 \mathrm{O}$ & 0.17 & 0.24 & 0.22 & 0.17 & 0.21 & 0.19 & 0.21 & 0.22 & 0.21 & 0.17 & 0.21 \\
\hline $\mathrm{Li}_{2} \mathrm{O}^{*}$ & $\S$ & $<0.01$ & $<0.01$ & $\S$ & $<0.01$ & $<0.01$ & $<0.01$ & $<0.01$ & $<0.01$ & $\S$ & $<0.01$ \\
\hline $\mathrm{MgO}$ & $\S$ & 0.75 & 0.82 & 1.00 & 0.87 & 0.90 & 0.82 & 0.70 & 0.60 & 1.00 & 0.68 \\
\hline $\mathrm{MnO}$ & $\S$ & 0.01 & 0.01 & $\S$ & $<0.01$ & 0.01 & $<0.01$ & 0.01 & 0.01 & $\S$ & 0.01 \\
\hline $\mathrm{Na}_{2} \mathrm{O}$ & 22.00 & 22.96 & 23.87 & 22.00 & 22.85 & 23.41 & 24.43 & 23.75 & 24.49 & 22.00 & 23.24 \\
\hline $\mathrm{NiO}$ & 0.04 & 0.19 & 0.19 & 0.04 & 0.18 & 0.16 & 0.17 & 0.19 & 0.20 & 0.04 & 0.22 \\
\hline $\mathrm{P}_{2} \mathrm{O}_{5}$ & 0.30 & 0.36 & 0.35 & 0.30 & 0.37 & 0.37 & 0.38 & 0.38 & 0.40 & 0.30 & 0.38 \\
\hline $\mathrm{PbO}$ & 0.01 & 0.02 & 0.02 & 0.01 & 0.01 & 0.02 & 0.01 & 0.02 & 0.02 & 0.01 & 0.02 \\
\hline $\mathrm{SiO}_{2}$ & \begin{tabular}{|l|}
37.38 \\
\end{tabular} & 37.23 & 36.71 & 37.28 & 37.10 & 37.25 & 36.97 & 36.65 & 36.57 & 37.19 & 36.76 \\
\hline $\mathrm{SnO}_{2}$ & $\S$ & 0.31 & 0.19 & $\S$ & 0.08 & 0.06 & 0.04 & 0.04 & 0.04 & $\S$ & 0.04 \\
\hline $\mathrm{SO}_{3}$ & 0.90 & 0.90 & 0.87 & 1.10 & 0.96 & 1.02 & 1.02 & 1.07 & 1.14 & 1.30 & 1.18 \\
\hline $\mathrm{TiO}_{2}$ & $\S$ & 0.16 & 0.17 & $\S$ & 0.20 & 0.18 & 0.16 & 0.16 & 0.15 & $\S$ & 0.18 \\
\hline $\mathrm{V}_{2} \mathrm{O}_{5}$ & 1.97 & 2.09 & 2.08 & 1.96 & 2.11 & 2.02 & 2.02 & 2.26 & 2.25 & 1.96 & 2.22 \\
\hline $\mathrm{ZnO}$ & 2.97 & 3.20 & 3.03 & 2.96 & 2.99 & 2.81 & 2.79 & 3.22 & 3.15 & 2.96 & 3.10 \\
\hline $\mathrm{ZrO}_{2}$ & 4.00 & 3.59 & 3.43 & 3.99 & 3.70 & 3.44 & 3.05 & 3.10 & 2.73 & 3.98 & 3.46 \\
\hline Sum & 10.13 & 100.00 & $\mid 100.00$ & $\mid 100.00$ & 100.00 & 100.00 & 100.00 & 100.00 & 100.00 & 100.00 & 100.00 \\
\hline
\end{tabular}

* - Target values calculated based on simple well-stirred tank model using DCP-AES analyzed boron and lithium concentrations in the first discharged glass sample

$\S$ - Not a target constituent

NA - not analyzed by XRF

“_“ sign for empty data field 
The Catholic University of America Vitreous State Laboratory

Table 4.2. XRF Analyzed Compositions for DM10 Discharged Glass Samples (wt\%) (continued).

\begin{tabular}{|c|c|c|c|c|c|c|c|c|c|c|c|}
\hline Formulation & \multicolumn{11}{|c|}{ ORPLD6 } \\
\hline Test & \multicolumn{5}{|c|}{ D3 } & \multicolumn{6}{|c|}{ D4 } \\
\hline Target $\mathrm{SO}_{3}$ & \multicolumn{5}{|c|}{$1.3 \%$} & \multicolumn{6}{|c|}{$1.2 \%$} \\
\hline Glass (kg) & - & 159.66 & 165.06 & 170.18 & 175.86 & - & 180.86 & 185.22 & 190.84 & 196.22 & 202.08 \\
\hline Constituent & Target & \begin{tabular}{|c|} 
Z10-G- \\
$46 C$
\end{tabular} & $\begin{array}{c}\mathrm{Z10}-\mathrm{G}- \\
50 \mathrm{~B}\end{array}$ & $\begin{array}{c}\text { Z10-G- } \\
51 B\end{array}$ & \begin{tabular}{|c} 
Z10-G- \\
$51 D$
\end{tabular} & Target & $\begin{array}{c}\text { Z10-G- } \\
54 \mathrm{~B}\end{array}$ & $\begin{array}{c}\mathrm{Z} 10-\mathrm{G} \\
58 \mathrm{~A}\end{array}$ & $\begin{array}{c}\text { Z10-G- } \\
59 A\end{array}$ & $\begin{array}{c}\text { Z10-G- } \\
60 \mathrm{~A}\end{array}$ & $\begin{array}{c}\mathrm{Z10-G} \\
60 \mathrm{C}\end{array}$ \\
\hline $\mathrm{Al}_{2} \mathrm{O}_{3}$ & \begin{tabular}{|l}
10.08 \\
\end{tabular} & 9.22 & 9.19 & 9.21 & 9.26 & \begin{tabular}{|l|}
10.09 \\
\end{tabular} & 9.24 & 9.20 & 9.14 & 8.97 & 8.73 \\
\hline $\mathrm{B}_{2} \mathrm{O}_{3}$ & 9.84 & 9.85 & 9.84 & 9.84 & 9.84 & 9.85 & 9.84 & 9.85 & 9.85 & 9.85 & 9.85 \\
\hline $\mathrm{CaO}$ & 7.88 & 8.05 & 7.89 & 7.95 & 7.92 & 7.89 & 7.98 & 8.06 & 8.11 & 8.08 & 8.29 \\
\hline $\mathrm{Cl}$ & 0.35 & 0.28 & 0.30 & 0.30 & 0.30 & 0.35 & 0.25 & 0.27 & 0.29 & 0.31 & 0.31 \\
\hline $\mathrm{Cr}_{2} \mathrm{O}_{3} *$ & 0.50 & 0.77 & 0.78 & 0.72 & 0.71 & 0.50 & 0.76 & 0.77 & 0.79 & 0.77 & 0.85 \\
\hline $\mathrm{Cs}_{2} \mathrm{O}$ & $\S$ & $<0.01$ & $<0.01$ & $<0.01$ & $<0.01$ & $\S$ & $<0.01$ & $<0.01$ & $<0.01$ & $<0.01$ & $<0.01$ \\
\hline $\mathrm{F}$ & 0.18 & NA & NA & NA & $\mathrm{NA}$ & 0.18 & $\mathrm{NA}$ & $\mathrm{NA}$ & $\mathrm{NA}$ & $\mathrm{NA}$ & NA \\
\hline $\mathrm{Fe}_{2} \mathrm{O}_{3}$ & 0.28 & 0.36 & 0.36 & 0.33 & 0.33 & 0.28 & 0.34 & 0.36 & 0.36 & 0.29 & 0.58 \\
\hline $\mathrm{I}$ & $\S$ & $<0.01$ & $<0.01$ & $<0.01$ & $<0.01$ & $\S$ & $<0.01$ & $<0.01$ & $<0.01$ & $<0.01$ & $<0.01$ \\
\hline $\mathrm{K} 2 \mathrm{O}$ & 0.17 & 0.21 & 0.20 & 0.21 & 0.20 & 0.17 & 0.20 & 0.21 & 0.21 & 0.20 & 0.22 \\
\hline $\mathrm{Li}_{2} \mathrm{O}^{*}$ & $\S$ & $<0.01$ & $<0.01$ & $<0.01$ & $<0.01$ & $\S$ & $<0.01$ & $<0.01$ & $<0.01$ & $<0.01$ & $<0.01$ \\
\hline $\mathrm{MgO}$ & 1.00 & 0.80 & 0.82 & 0.79 & 0.75 & 1.00 & 0.74 & 0.81 & 0.82 & 0.63 & 0.52 \\
\hline $\mathrm{MnO}$ & $\S$ & 0.01 & 0.01 & 0.01 & $<0.01$ & $\S$ & 0.01 & 0.01 & 0.01 & $<0.01$ & 0.01 \\
\hline $\mathrm{Na}_{2} \mathrm{O}$ & 22.00 & 23.06 & 23.36 & 23.39 & 23.33 & 22.00 & 23.10 & 23.07 & 22.62 & 23.26 & 23.17 \\
\hline $\mathrm{NiO}$ & 0.04 & 0.22 & 0.22 & 0.18 & 0.18 & 0.04 & 0.23 & 0.23 & 0.22 & 0.21 & 0.24 \\
\hline $\mathrm{P}_{2} \mathrm{O}_{5}$ & 0.30 & 0.37 & 0.37 & 0.38 & 0.37 & 0.30 & 0.37 & 0.37 & 0.37 & 0.39 & 0.39 \\
\hline $\mathrm{PbO}$ & 0.01 & 0.02 & 0.02 & 0.02 & 0.02 & 0.01 & 0.02 & 0.02 & 0.02 & 0.02 & 0.02 \\
\hline $\mathrm{SiO}^{2}$ & 37.19 & 36.52 & 36.37 & 36.48 & 36.68 & 37.24 & 36.61 & 36.33 & 36.74 & 37.10 & 36.80 \\
\hline $\mathrm{SnO}_{2}$ & $\S$ & 0.03 & 0.03 & 0.02 & 0.02 & $\S$ & 0.03 & 0.02 & 0.02 & 0.02 & 0.02 \\
\hline $\mathrm{SO}_{3}$ & 1.30 & 1.23 & 1.32 & 1.29 & 1.27 & 1.20 & 1.25 & 1.26 & 1.26 & 1.25 & 1.26 \\
\hline $\mathrm{TiO}_{2}$ & $\S$ & 0.19 & 0.19 & 0.19 & 0.19 & $\S$ & 0.19 & 0.19 & 0.19 & 0.17 & 0.16 \\
\hline $\mathrm{V}_{2} \mathrm{O}_{5}$ & 1.96 & 2.18 & 2.15 & 2.16 & 2.15 & 1.96 & 2.18 & 2.21 & 2.20 & 2.22 & 2.27 \\
\hline $\mathrm{ZnO}$ & 2.96 & 3.08 & 3.00 & 2.99 & 2.99 & 2.96 & 3.03 & 3.10 & 3.11 & 3.08 & 3.21 \\
\hline $\mathrm{ZrO}_{2}$ & 3.98 & 3.57 & 3.59 & 3.54 & 3.50 & 3.98 & 3.63 & 3.67 & 3.67 & 3.17 & 3.11 \\
\hline Sum & 100.00 & 100.00 & 100.00 & 100.00 & 100.00 & 100.00 & 100.00 & 100.00 & 100.00 & 100.00 & 100.00 \\
\hline
\end{tabular}

* - Target values calculated based on simple well-stirred tank model using DCP-AES analyzed boron and lithium concentrations in the first discharged glass sample

$\S$ - Not a target constituent

NA - not analyzed by XRF

“_“ sign for empty data field 
The Catholic University of America Vitreous State Laboratory

Table 4.2. XRF Analyzed Compositions for DM10 Discharged Glass Samples (wt\%) (continued).

\begin{tabular}{|c|c|c|c|c|c|c|c|c|c|c|c|}
\hline Formulation & \multicolumn{9}{|c|}{ ORPLD6 } & \multicolumn{2}{|c|}{ ORPLF7 } \\
\hline Test & \multicolumn{9}{|c|}{ D5 } & \multicolumn{2}{|c|}{ F1 } \\
\hline Target $\mathrm{SO}_{3}$ & \multicolumn{9}{|c|}{$1.2 \%$} & \multicolumn{2}{|c|}{$1.6 \%$} \\
\hline Glass (kg) & - & \begin{tabular}{|l|}
206.52 \\
\end{tabular} & 211.82 & 215.92 & 220.04 & 223.92 & 227.18 & 230.98 & 232.98 & - & 238.90 \\
\hline Constituent & Target & $\begin{array}{c}10 \mathrm{~A}-\mathrm{G}- \\
45 \mathrm{~B}\end{array}$ & $\begin{array}{c}10 \mathrm{~A}-\mathrm{G}- \\
51 \mathrm{~B}\end{array}$ & $\begin{array}{c}10 \mathrm{~A}-\mathrm{G}- \\
51 \mathrm{D}\end{array}$ & $\begin{array}{c}10 \mathrm{~A}-\mathrm{G}- \\
52 \mathrm{~B}\end{array}$ & $\begin{array}{c}10 \mathrm{~A}-\mathrm{G}- \\
52 \mathrm{D}\end{array}$ & $\begin{array}{c}10 \mathrm{~A}-\mathrm{G}- \\
52 \mathrm{~F}\end{array}$ & $\begin{array}{c}10 \mathrm{~A}-\mathrm{G}- \\
53 \mathrm{~B}\end{array}$ & $\begin{array}{c}10 \mathrm{~A}-\mathrm{G}- \\
53 \mathrm{C}\end{array}$ & Target & $\begin{array}{c}\mathrm{Z} 10-\mathrm{G} \\
86 \mathrm{~A}\end{array}$ \\
\hline $\mathrm{Al}_{2} \mathrm{O}_{3}$ & 10.09 & 7.57 & 8.63 & 8.84 & 9.46 & 9.64 & 9.74 & 9.70 & 9.61 & 8.64 & 7.12 \\
\hline $\mathrm{B}_{2} \mathrm{O}_{3}$ & 9.85 & 8.97 & 9.33 & 9.51 & 9.62 & 9.70 & 9.74 & 9.77 & 9.79 & 9.54 & 8.88 \\
\hline $\mathrm{CaO}$ & 7.89 & 4.23 & 5.44 & 5.98 & 6.74 & 7.13 & 7.32 & 7.34 & 7.41 & 9.77 & 5.10 \\
\hline $\mathrm{Cl}$ & 0.35 & 0.18 & 0.19 & 0.21 & 0.21 & 0.23 & 0.22 & 0.23 & 0.24 & 0.01 & 0.08 \\
\hline $\mathrm{Cr}_{2} \mathrm{O}_{3}$ * & 0.50 & 0.81 & 0.76 & 0.77 & 0.75 & 0.74 & 0.75 & 0.75 & 0.79 & 0.56 & 0.48 \\
\hline $\mathrm{Cs}_{2} \mathrm{O}$ & $\S$ & $<0.01$ & $<0.01$ & $<0.01$ & $<0.01$ & $<0.01$ & $<0.01$ & $<0.01$ & $<0.01$ & $\S$ & 0.07 \\
\hline F & 0.18 & NA & NA & NA & NA & NA & NA & NA & NA & 0.08 & NA \\
\hline $\mathrm{Fe}_{2} \mathrm{O}_{3}$ & 0.28 & 0.33 & 0.38 & 0.43 & 0.44 & 0.43 & 0.42 & 0.40 & 0.82 & 0.23 & 4.41 \\
\hline I & $\S$ & 0.07 & 0.04 & 0.04 & 0.02 & 0.01 & $<0.01$ & 0.01 & 0.01 & $\S$ & $<0.01$ \\
\hline $\mathrm{K} 2 \mathrm{O}$ & 0.17 & 3.90 & 2.40 & 1.95 & 1.02 & 0.69 & 0.53 & 0.43 & 0.37 & 0.50 & 0.45 \\
\hline $\mathrm{Li}_{2} \mathrm{O}^{*}$ & $\S$ & $<0.01$ & $<0.01$ & $<0.01$ & $<0.01$ & $<0.01$ & $<0.01$ & $<0.01$ & $<0.01$ & 4.37 & 1.79 \\
\hline $\mathrm{MgO}$ & 1.00 & 0.92 & 1.00 & 0.92 & 1.04 & 0.95 & 0.90 & 0.81 & 0.81 & 0.98 & 1.60 \\
\hline $\mathrm{MnO}$ & $\S$ & 0.01 & 0.02 & 0.02 & 0.02 & 0.03 & 0.03 & 0.03 & 0.03 & $\S$ & 0.02 \\
\hline $\mathrm{Na}_{2} \mathrm{O}$ & 22.00 & 21.82 & 21.98 & 21.31 & 21.76 & 21.55 & 21.64 & 22.34 & 21.94 & 12.00 & 16.95 \\
\hline $\mathrm{NiO}$ & 0.04 & 0.04 & 0.04 & 0.05 & 0.05 & 0.05 & 0.05 & 0.05 & 0.05 & $\S$ & 0.21 \\
\hline $\mathrm{P}_{2} \mathrm{O}_{5}$ & 0.30 & 0.24 & 0.30 & 0.32 & 0.36 & 0.37 & 0.38 & 0.39 & 0.39 & 0.04 & 0.07 \\
\hline $\mathrm{PbO}$ & 0.01 & 0.02 & 0.01 & 0.02 & 0.02 & 0.02 & 0.02 & 0.01 & 0.02 & $\S$ & $<0.01$ \\
\hline $\mathrm{SiO}^{2}$ & 37.24 & 39.36 & 38.51 & 38.39 & 37.84 & 37.70 & 37.46 & 37.19 & 37.02 & 42.34 & 43.14 \\
\hline $\mathrm{SnO}_{2}$ & $\S$ & 2.15 & 1.27 & 1.06 & 0.47 & 0.30 & 0.21 & 0.15 & 0.13 & $\S$ & 0.02 \\
\hline $\mathrm{SO}_{3}$ & 1.20 & 0.49 & 0.76 & 0.86 & 1.02 & 1.13 & 1.12 & 1.23 & 1.25 & 1.60 & 0.81 \\
\hline $\mathrm{TiO}_{2}$ & $\S$ & 0.15 & 0.17 & 0.19 & 0.20 & 0.21 & 0.21 & 0.20 & 0.20 & $\S$ & 0.51 \\
\hline $\mathrm{V}_{2} \mathrm{O}_{5}$ & 1.96 & 0.72 & 1.30 & 1.52 & 1.85 & 2.03 & 2.11 & 2.14 & 2.16 & 2.51 & 1.96 \\
\hline $\mathrm{ZnO}$ & 2.96 & 3.27 & 3.11 & 3.23 & 3.06 & 3.11 & 3.15 & 3.07 & 3.11 & 2.92 & 3.06 \\
\hline $\mathrm{ZrO}_{2}$ & 3.98 & 4.76 & 4.33 & 4.40 & 4.04 & 3.98 & 4.00 & 3.77 & 3.88 & 3.90 & 3.28 \\
\hline Sum & 100.00 & 100.00 & 100.00 & 100.00 & 100.00 & 100.00 & 100.00 & 100.00 & 100.00 & 100.00 & 100.00 \\
\hline
\end{tabular}

* - Target values calculated based on simple well-stirred tank model using DCP-AES analyzed boron and lithium concentrations in the first discharged glass sample

$\S$ - Not a target constituent

NA - not analyzed by XRF

“_“ sign for empty data field 
The Catholic University of America Vitreous State Laboratory
Glass Formulation Development and DM10 Melter Testing with ORP LAW Glasses

Final Report, VSL-09R1510-2, Rev. 0

Table 4.2. XRF Analyzed Compositions for DM10 Discharged Glass Samples (wt\%) (continued).

\begin{tabular}{|c|c|c|c|c|c|c|c|c|c|c|c|}
\hline Formulation & \multicolumn{11}{|c|}{ ORPLF7 } \\
\hline Test & \multicolumn{6}{|c|}{ F1 } & \multicolumn{5}{|c|}{ F2 } \\
\hline Target $\mathrm{SO}_{3}$ & \multicolumn{6}{|c|}{$1.6 \%$} & \multicolumn{5}{|c|}{$1.4 \%$} \\
\hline Glass (kg) & - & 243.30 & 248.20 & 253.44 & 257.94 & 259.94 & - & 265.12 & 270.20 & 274.62 & 279.10 \\
\hline Constituent & Target & $\begin{array}{c}\text { Z10-G- } \\
86 C\end{array}$ & $\begin{array}{c}\text { Z10-G- } \\
89 B\end{array}$ & $\begin{array}{c}\text { Z10-G- } \\
89 D\end{array}$ & $\begin{array}{c}\text { Z10-G- } \\
90 \mathrm{~A}\end{array}$ & $\begin{array}{c}\text { Z10-G- } \\
\text { 90B }\end{array}$ & Target & $\begin{array}{c}\text { Z10-G- } \\
95 B\end{array}$ & $\begin{array}{c}\text { Z10-G- } \\
\text { 97B }\end{array}$ & $\begin{array}{c}\text { Z10-G- } \\
98 \mathrm{~B}\end{array}$ & $\begin{array}{c}\text { Z10-G- } \\
98 D\end{array}$ \\
\hline $\mathrm{Al}_{2} \mathrm{O}_{3}$ & 8.64 & 7.52 & 7.73 & 7.80 & 7.88 & 8.04 & 8.66 & 7.94 & 8.10 & 8.09 & 8.07 \\
\hline $\mathrm{B}_{2} \mathrm{O}_{3}$ & 9.54 & 9.12 & 9.28 & 9.39 & 9.45 & 9.46 & 9.57 & 9.50 & 9.53 & 9.54 & 9.55 \\
\hline $\mathrm{CaO}$ & 9.77 & 6.78 & 7.68 & 8.50 & 9.08 & 9.21 & 9.79 & 9.45 & 9.76 & 9.71 & 9.90 \\
\hline $\mathrm{Cl}$ & 0.01 & 0.06 & 0.03 & 0.03 & 0.02 & 0.02 & 0.01 & 0.01 & 0.02 & 0.02 & 0.02 \\
\hline $\mathrm{Cr}_{2} \mathrm{O}_{3} *$ & 0.56 & 0.58 & 0.65 & 0.71 & 0.74 & 0.74 & 0.56 & 0.76 & 0.77 & 0.77 & 0.78 \\
\hline $\mathrm{Cs}_{2} \mathrm{O}$ & $\S$ & 0.05 & $<0.01$ & 0.02 & 0.01 & $<0.01$ & $\S$ & $<0.01$ & $<0.01$ & $<0.01$ & $<0.01$ \\
\hline $\mathrm{F}$ & 0.08 & NA & NA & NA & NA & NA & 0.08 & NA & NA & NA & NA \\
\hline $\mathrm{Fe}_{2} \mathrm{O}_{3}$ & 0.23 & 2.89 & 2.11 & 1.54 & 1.19 & 0.94 & 0.23 & 0.84 & 0.67 & 0.59 & 0.56 \\
\hline I & $\S$ & $<0.01$ & $<0.01$ & $<0.01$ & $<0.01$ & $<0.01$ & $\S$ & $<0.01$ & $<0.01$ & $<0.01$ & $<0.01$ \\
\hline $\mathrm{K} 2 \mathrm{O}$ & 0.50 & 0.48 & 0.48 & 0.50 & 0.50 & 0.50 & 0.50 & 0.52 & 0.53 & 0.52 & 0.54 \\
\hline $\mathrm{Li}_{2} \mathrm{O}^{*}$ & 4.37 & 2.71 & 3.35 & 3.77 & 3.99 & 4.06 & 4.38 & 4.19 & 4.26 & 4.31 & 4.33 \\
\hline $\mathrm{MgO}$ & 0.98 & 1.38 & 1.29 & 1.20 & 1.13 & 1.10 & 0.99 & 1.07 & 1.01 & 1.02 & 1.03 \\
\hline $\mathrm{MnO}$ & $\S$ & 0.01 & 0.01 & 0.01 & 0.01 & 0.01 & $\S$ & 0.01 & 0.01 & 0.01 & 0.01 \\
\hline $\mathrm{Na}_{2} \mathrm{O}$ & 12.00 & 15.30 & 14.35 & 13.53 & 12.76 & 12.18 & 12.00 & 12.35 & 11.80 & 12.17 & 11.78 \\
\hline $\mathrm{NiO}$ & $\S$ & 0.15 & 0.11 & 0.08 & 0.06 & 0.05 & $\S$ & 0.05 & 0.04 & 0.03 & 0.03 \\
\hline $\mathrm{P}_{2} \mathrm{O}_{5}$ & 0.04 & 0.07 & 0.08 & 0.07 & 0.06 & 0.07 & 0.04 & 0.08 & 0.07 & 0.07 & 0.08 \\
\hline $\mathrm{PbO}$ & $\S$ & $<0.01$ & $<0.01$ & $<0.01$ & $<0.01$ & $<0.01$ & $\S$ & $<0.01$ & 0.02 & $<0.01$ & $<0.01$ \\
\hline $\mathrm{SiO}^{2}$ & 42.34 & 42.83 & 42.52 & 42.02 & 42.41 & 42.75 & 42.44 & 42.14 & 42.27 & 42.30 & 42.18 \\
\hline $\mathrm{SnO}_{2}$ & $\S$ & 0.02 & 0.01 & 0.02 & 0.01 & 0.01 & $\S$ & 0.01 & 0.02 & 0.01 & 0.01 \\
\hline $\mathrm{SO}_{3}$ & 1.60 & 1.06 & 1.15 & 1.26 & 1.34 & 1.38 & 1.40 & 1.29 & 1.26 & 1.27 & 1.26 \\
\hline $\mathrm{TiO}_{2}$ & $\S$ & 0.40 & 0.34 & 0.29 & 0.26 & 0.24 & $\S$ & 0.23 & 0.22 & 0.21 & 0.21 \\
\hline $\mathrm{V}_{2} \mathrm{O}_{5}$ & 2.51 & 2.22 & 2.38 & 2.56 & 2.63 & 2.65 & 2.52 & 2.73 & 2.80 & 2.75 & 2.80 \\
\hline $\mathrm{ZnO}$ & 2.92 & 2.95 & 2.95 & 3.00 & 2.95 & 2.94 & 2.93 & 3.00 & 3.02 & 2.91 & 3.03 \\
\hline $\mathrm{ZrO}_{2}$ & 3.90 & 3.44 & 3.50 & 3.70 & 3.51 & 3.66 & 3.91 & 3.80 & 3.81 & 3.71 & 3.84 \\
\hline Sum & 100.00 & \begin{tabular}{|l|}
100.00 \\
\end{tabular} & 100.00 & 100.00 & 100.00 & 100.00 & 100.00 & \begin{tabular}{|l|}
100.00 \\
\end{tabular} & 100.00 & 100.00 & 100.00 \\
\hline
\end{tabular}

* - Target values calculated based on simple well-stirred tank model using DCP-AES analyzed boron and lithium concentrations in the first discharged glass sample

$\S$ - Not a target constituent

NA - not analyzed by XRF

“_“ sign for empty data field 
The Catholic University of America Vitreous State Laboratory

Table 4.2. XRF Analyzed Compositions for DM10 Discharged Glass Samples (wt\%) (continued).

\begin{tabular}{|c|c|c|c|c|c|c|c|c|c|c|c|}
\hline Formulation & \multicolumn{11}{|c|}{ ORPLF7 } \\
\hline Test & \multicolumn{3}{|c|}{ F2 } & \multicolumn{8}{|c|}{ F3 } \\
\hline Target $\mathrm{SO}_{3}$ & \multicolumn{3}{|c|}{$1.4 \%$} & \multicolumn{8}{|c|}{$1.2 \%$} \\
\hline Glass (kg) & - & 283.34 & 287.24 & - & 291.94 & 295.86 & 299.34 & 302.62 & 306.52 & 309.56 & 311.84 \\
\hline Constituent & Target & $\begin{array}{c}\text { Z10-G- } \\
99 B\end{array}$ & $\begin{array}{c}\mathrm{Z10-G} \\
99 \mathrm{D}\end{array}$ & Target & \begin{tabular}{|c|} 
Z10-G- \\
104B
\end{tabular} & $\begin{array}{c}\text { Z10-G- } \\
105 A\end{array}$ & $\begin{array}{c}\text { Z10-G- } \\
105 C\end{array}$ & $\begin{array}{c}\text { Z10-G- } \\
\text { 107B }\end{array}$ & \begin{tabular}{|c|} 
Z10-G- \\
110B
\end{tabular} & $\begin{array}{c}\text { Z10-G- } \\
\text { 111B }\end{array}$ & $\begin{array}{r}\text { Z10-G } \\
111 C\end{array}$ \\
\hline $\mathrm{Al}_{2} \mathrm{O}_{3}$ & 8.66 & 8.06 & 8.07 & 8.68 & 8.19 & 8.12 & 8.24 & 8.22 & 8.20 & 8.15 & 8.12 \\
\hline $\mathrm{B}_{2} \mathrm{O}_{3}$ & 9.57 & 9.56 & 9.56 & 9.59 & 9.57 & 9.58 & 9.58 & 9.58 & 9.58 & 9.59 & 9.59 \\
\hline $\mathrm{CaO}$ & 9.79 & 10.15 & 9.90 & 9.81 & 9.89 & 9.99 & 9.94 & 9.89 & 9.91 & 10.03 & 9.94 \\
\hline $\mathrm{Cl}$ & 0.01 & 0.02 & 0.02 & 0.01 & 0.02 & 0.02 & 0.02 & 0.02 & 0.02 & 0.01 & 0.01 \\
\hline $\mathrm{Cr}_{2} \mathrm{O}_{3} *$ & 0.56 & 0.80 & 0.79 & 0.57 & 0.79 & 0.80 & 0.79 & 0.79 & 0.79 & 0.81 & 0.81 \\
\hline $\mathrm{Cs}_{2} \mathrm{O}$ & $\S$ & $<0.01$ & $<0.01$ & $\S$ & $<0.01$ & $<0.01$ & $<0.01$ & $<0.01$ & $<0.01$ & $<0.01$ & $<0.01$ \\
\hline $\mathrm{F}$ & 0.08 & NA & NA & 0.08 & $\mathrm{NA}$ & NA & $\mathrm{NA}$ & NA & $\mathrm{NA}$ & $\mathrm{NA}$ & NA \\
\hline $\mathrm{Fe}_{2} \mathrm{O}_{3}$ & 0.23 & 0.46 & 0.44 & 0.23 & 0.40 & 0.43 & 0.56 & 0.49 & 0.45 & 0.38 & 0.46 \\
\hline $\mathrm{I}$ & $\S$ & $<0.01$ & $<0.01$ & $\S$ & $<0.01$ & $<0.01$ & $<0.01$ & $<0.01$ & $<0.01$ & $<0.01$ & $<0.01$ \\
\hline $\mathrm{K} 2 \mathrm{O}$ & 0.50 & 0.54 & 0.53 & 0.50 & 0.54 & 0.53 & 0.52 & 0.52 & 0.52 & 0.54 & 0.53 \\
\hline $\mathrm{Li}_{2} \mathrm{O}^{*}$ & 4.38 & 4.35 & 4.36 & 4.39 & 4.37 & 4.38 & 4.38 & 4.38 & 4.39 & 4.39 & 4.39 \\
\hline $\mathrm{MgO}$ & 0.99 & 1.04 & 0.95 & 0.99 & 1.00 & 1.00 & 1.04 & 1.04 & 1.05 & 1.02 & 0.96 \\
\hline $\mathrm{MnO}$ & $\S$ & 0.01 & 0.01 & $\S$ & 0.01 & 0.01 & 0.01 & 0.01 & 0.01 & 0.01 & 0.01 \\
\hline $\mathrm{Na}_{2} \mathrm{O}$ & 12.00 & 11.46 & 12.26 & 12.00 & 12.04 & 11.69 & 11.45 & 11.84 & 12.13 & 11.98 & 11.47 \\
\hline $\mathrm{NiO}$ & $\S$ & 0.02 & 0.02 & $\S$ & 0.02 & 0.02 & 0.02 & 0.02 & 0.02 & 0.02 & 0.02 \\
\hline $\mathrm{P}_{2} \mathrm{O}_{5}$ & 0.04 & 0.08 & 0.08 & 0.04 & 0.07 & 0.07 & 0.07 & 0.07 & 0.08 & 0.07 & 0.06 \\
\hline $\mathrm{PbO}$ & $\S$ & $<0.01$ & $<0.01$ & $\S$ & 0.01 & $<0.01$ & $<0.01$ & $<0.01$ & $<0.01$ & $<0.01$ & $<0.01$ \\
\hline $\mathrm{SiO}^{2}$ & 42.44 & 42.18 & 42.13 & 42.54 & 42.21 & 42.30 & 42.53 & 42.23 & 42.15 & 42.26 & 42.66 \\
\hline $\mathrm{SnO}_{2}$ & $\S$ & $<0.01$ & 0.01 & $<0.01$ & $<0.01$ & $<0.01$ & $<0.01$ & $<0.01$ & $<0.01$ & 0.01 & 0.01 \\
\hline $\mathrm{SO}_{3}$ & 1.40 & 1.28 & 1.27 & 1.20 & 1.21 & 1.17 & 1.15 & 1.09 & 1.11 & 1.10 & 1.10 \\
\hline $\mathrm{TiO}_{2}$ & $\S$ & 0.21 & 0.20 & $\S$ & 0.20 & 0.20 & 0.20 & 0.20 & 0.20 & 0.20 & 0.19 \\
\hline $\mathrm{V}_{2} \mathrm{O}_{5}$ & 2.52 & 2.90 & 2.81 & 2.52 & 2.77 & 2.85 & 2.82 & 2.78 & 2.78 & 2.83 & 2.87 \\
\hline $\mathrm{ZnO}$ & 2.93 & 3.06 & 2.99 & 2.94 & 2.93 & 3.02 & 2.95 & 2.98 & 2.98 & 3.01 & 3.05 \\
\hline $\mathrm{ZrO}_{2}$ & 3.91 & 3.82 & 3.59 & 3.92 & 3.73 & 3.81 & 3.73 & 3.83 & 3.62 & 3.59 & 3.76 \\
\hline Sum & 100.00 & 100.00 & 100.00 & 100.00 & 100.00 & 100.00 & 100.00 & 100.00 & \begin{tabular}{|l|l}
100.00 \\
\end{tabular} & 100.00 & 100.00 \\
\hline
\end{tabular}

* - Target values calculated based on simple well-stirred tank model using DCP-AES analyzed boron and lithium concentrations in the first discharged glass sample

$\S$ - Not a target constituent

NA - not analyzed by XRF

“_“ sign for empty data field 
The Catholic University of America Vitreous State Laboratory

Table 4.2. XRF Analyzed Compositions for DM10 Discharged Glass Samples (wt\%) (continued).

\begin{tabular}{|c|c|c|c|c|c|c|c|c|c|c|c|}
\hline Formulation & \multicolumn{11}{|c|}{ ORPLF7 } \\
\hline Test & \multicolumn{8}{|c|}{ F4 } & \multicolumn{3}{|c|}{ F5** } \\
\hline Target $\mathrm{SO}_{3}$ & \multicolumn{8}{|c|}{$0.8 \%$} & \multicolumn{3}{|c|}{$1.4 \%$} \\
\hline Glass (kg) & - & \begin{tabular}{|l|}
317.14 \\
\end{tabular} & 321.40 & \begin{tabular}{|l|}
325.22 \\
\end{tabular} & \begin{tabular}{|l|}
328.47 \\
\end{tabular} & 331.83 & 335.25 & 337.63 & - & 343.05 & 347.91 \\
\hline Constituent & Target & \begin{tabular}{|c|} 
Z10-G- \\
$113 B$
\end{tabular} & $\begin{array}{c}\text { Z10-G- } \\
115 B\end{array}$ & \begin{tabular}{|c|} 
Z10-G- \\
$118 B$
\end{tabular} & $\begin{array}{c}\text { Z10-G- } \\
\text { 119B }\end{array}$ & $\begin{array}{c}\text { Z10-G- } \\
121 \mathrm{~A}\end{array}$ & $\begin{array}{c}\text { Z10-G- } \\
121 C\end{array}$ & $\begin{array}{c}\text { Z10-G- } \\
122 B\end{array}$ & Target & $\begin{array}{c}\text { Z10-G- } \\
\text { 141B }\end{array}$ & $\begin{array}{c}\text { Z10-G- } \\
142 A\end{array}$ \\
\hline $\mathrm{Al}_{2} \mathrm{O}_{3}$ & 8.72 & 8.09 & 8.20 & 8.26 & 8.21 & 8.20 & 8.31 & 8.18 & 8.66 & 7.99 & 8.08 \\
\hline $\mathrm{B}_{2} \mathrm{O}_{3}$ & 9.63 & 9.61 & 9.61 & 9.62 & 9.62 & 9.63 & 9.63 & 9.63 & 9.57 & 9.12 & 9.29 \\
\hline $\mathrm{CaO}$ & 9.86 & 9.88 & 9.72 & 9.69 & 9.82 & 10.07 & 9.71 & 9.95 & 9.79 & 7.73 & 8.52 \\
\hline $\mathrm{Cl}$ & 0.01 & 0.02 & 0.01 & 0.02 & 0.02 & 0.01 & 0.01 & 0.01 & 0.01 & 0.02 & 0.01 \\
\hline $\mathrm{Cr}_{2} \mathrm{O}_{3} *$ & 0.57 & 0.80 & 0.79 & 0.78 & 0.80 & 0.82 & 0.77 & 0.81 & 0.56 & 0.70 & 0.73 \\
\hline $\mathrm{Cs}_{2} \mathrm{O}$ & $\S$ & $<0.01$ & 0.01 & $<0.01$ & $<0.01$ & $<0.01$ & $<0.01$ & $<0.01$ & $\S$ & 0.02 & 0.02 \\
\hline$F$ & 0.08 & NA & NA & NA & NA & NA & NA & NA & 0.08 & NA & NA \\
\hline $\mathrm{Fe}_{2} \mathrm{O}_{3}$ & 0.23 & 0.41 & 0.38 & 0.37 & 0.39 & 0.38 & 0.42 & 0.43 & 0.23 & 2.03 & 1.38 \\
\hline $\mathrm{I}$ & $\S$ & $<0.01$ & $<0.01$ & $<0.01$ & $<0.01$ & $<0.01$ & $<0.01$ & $<0.01$ & $\S$ & $<0.01$ & $<0.01$ \\
\hline K2O & 0.50 & 0.54 & 0.52 & 0.52 & 0.51 & 0.53 & 0.51 & 0.53 & 0.50 & 0.51 & 0.52 \\
\hline $\mathrm{Li}_{2} \mathrm{O}^{*}$ & 4.41 & 4.40 & 4.40 & 4.40 & 4.41 & 4.41 & 4.41 & 4.41 & 4.38 & 3.23 & 3.67 \\
\hline $\mathrm{MgO}$ & 0.99 & 0.95 & 1.04 & 1.01 & 1.06 & 1.02 & 1.02 & 1.00 & 0.99 & 1.29 & 1.16 \\
\hline $\mathrm{MnO}$ & $\S$ & 0.01 & 0.01 & 0.01 & 0.01 & 0.01 & 0.01 & 0.01 & $\S$ & 0.02 & 0.02 \\
\hline $\mathrm{Na}_{2} \mathrm{O}$ & 12.00 & 11.75 & 12.05 & 11.99 & 11.77 & 11.53 & 12.33 & 11.74 & 12.00 & 14.32 & 13.81 \\
\hline $\mathrm{NiO}$ & $\S$ & 0.02 & 0.01 & 0.02 & 0.02 & 0.02 & 0.01 & 0.01 & $\S$ & 0.02 & 0.02 \\
\hline $\mathrm{P}_{2} \mathrm{O}_{5}$ & 0.04 & 0.08 & 0.07 & 0.08 & 0.07 & 0.07 & 0.07 & 0.08 & 0.04 & 0.08 & 0.07 \\
\hline $\mathrm{PbO}$ & $\S$ & $<0.01$ & $<0.01$ & $<0.01$ & $<0.01$ & $<0.01$ & $<0.01$ & $<0.01$ & $\S$ & $<0.01$ & $<0.01$ \\
\hline $\mathrm{SiO}^{2}$ & 42.73 & 42.63 & 42.73 & 43.01 & 42.81 & 42.44 & 42.57 & 42.63 & 42.44 & 42.98 & 42.26 \\
\hline $\mathrm{SnO}_{2}$ & $\S$ & $<0.01$ & $<0.01$ & 0.01 & 0.01 & 0.01 & $<0.01$ & 0.01 & $\S$ & 0.02 & 0.02 \\
\hline $\mathrm{SO}_{3}$ & 0.80 & 1.08 & 0.92 & 0.85 & 0.81 & 0.79 & 0.77 & 0.76 & 1.40 & 1.00 & 1.10 \\
\hline $\mathrm{TiO}_{2}$ & $\S$ & 0.20 & 0.19 & 0.19 & 0.20 & 0.20 & 0.20 & 0.19 & $\S$ & 0.32 & 0.27 \\
\hline $\mathrm{V}_{2} \mathrm{O}_{5}$ & 2.53 & 2.83 & 2.75 & 2.74 & 2.80 & 2.94 & 2.73 & 2.85 & 2.52 & 2.44 & 2.55 \\
\hline $\mathrm{ZnO}$ & 2.95 & 2.98 & 2.90 & 2.89 & 2.98 & 3.11 & 2.91 & 3.03 & 2.93 & 2.94 & 2.93 \\
\hline $\mathrm{ZrO}_{2}$ & 3.93 & 3.73 & 3.67 & 3.54 & 3.68 & 3.79 & 3.61 & 3.74 & 3.91 & 3.23 & 3.56 \\
\hline Sum & 100.00 & 100.00 & 100.00 & 100.00 & 100.00 & 100.00 & 100.00 & \begin{tabular}{|l|}
100.00 \\
\end{tabular} & \begin{tabular}{|l|}
100.00 \\
\end{tabular} & 100.00 & 100.00 \\
\hline $\begin{array}{l}\S \text { - Not a } \\
\text { NA - not } \\
\text { “_“ sign fo }\end{array}$ & $\begin{array}{l}\text { arget c } \\
\text { nalyze } \\
\text { empt }\end{array}$ & $\begin{array}{l}\text { alculated } \\
\text { ions in th } \\
\text { onstituent } \\
\text { by XRF } \\
\text { data fielc }\end{array}$ & ased & simp & ell-s & $\begin{array}{l}\text { ed tar } \\
\text { aple }\end{array}$ & & & & lyze & oron \\
\hline
\end{tabular}


The Catholic University of America Vitreous State Laboratory
Glass Formulation Development and DM10 Melter Testing with ORP LAW Glasses

Final Report, VSL-09R1510-2, Rev. 0

Table 4.2. XRF Analyzed Compositions for DM10 Discharged Glass Samples (wt\%) (continued).

\begin{tabular}{|c|c|c|c|c|c|c|c|c|c|c|}
\hline Formulation & \multicolumn{10}{|c|}{ ORPLF7 } \\
\hline Test & \multicolumn{4}{|c|}{ F5 } & \multicolumn{6}{|c|}{ F6 } \\
\hline Target $\mathrm{SO}_{3}$ & \multicolumn{4}{|c|}{$1.4 \%$} & \multicolumn{6}{|c|}{$1.5 \%$} \\
\hline Glass (kg) & - & 353.97 & 358.45 & 360.53 & - & \begin{tabular}{|l|}
366.03 \\
\end{tabular} & 370.71 & 376.33 & 382.25 & 387.63 \\
\hline Constituent & Target & \begin{tabular}{|c|} 
Z10-G- \\
$142 C$
\end{tabular} & $\begin{array}{c}\text { Z10-G- } \\
143 A\end{array}$ & $\begin{array}{c}\text { Z10-G- } \\
143 B\end{array}$ & Target & \begin{tabular}{|c|} 
Z10-G- \\
$146 B$
\end{tabular} & $\begin{array}{c}\text { Z10-G- } \\
148 B\end{array}$ & $\begin{array}{c}\text { Z10-G- } \\
149 A\end{array}$ & \begin{tabular}{|c} 
Z10-G- \\
$153 A$
\end{tabular} & $\begin{array}{c}\text { Z10-G- } \\
153 B\end{array}$ \\
\hline $\mathrm{Al}_{2} \mathrm{O}_{3}$ & 8.66 & 8.11 & 8.16 & 8.12 & 8.65 & 8.24 & 8.27 & 8.33 & 8.36 & 8.37 \\
\hline $\mathrm{B}_{2} \mathrm{O}_{3}$ & 9.57 & 9.42 & 9.47 & 9.49 & 9.56 & 9.52 & 9.53 & 9.54 & 9.55 & 9.55 \\
\hline $\mathrm{CaO}$ & 9.79 & 9.06 & 9.07 & 9.35 & 9.78 & 9.52 & 9.61 & 9.52 & 9.63 & 9.66 \\
\hline $\mathrm{Cl}$ & 0.01 & $<0.01$ & 0.01 & 0.03 & 0.01 & 0.01 & 0.02 & 0.01 & 0.01 & 0.01 \\
\hline $\mathrm{Cr}_{2} \mathrm{O}_{3} *$ & 0.56 & 0.77 & 0.77 & 0.77 & 0.56 & 0.83 & 0.81 & 0.79 & .80 & 0.80 \\
\hline $\mathrm{Cs}_{2} \mathrm{O}$ & $\S$ & $<0.01$ & 0.01 & 0.01 & $\S$ & 0.01 & $<0.01$ & $<0.01$ & $<0.01$ & $<0.01$ \\
\hline $\mathrm{F}$ & 0.08 & NA & NA & NA & 0.08 & NA & NA & NA & NA & NA \\
\hline $\mathrm{Fe}_{2} \mathrm{O}_{3}$ & 0.23 & 1.00 & 0.80 & 0.77 & 0.23 & 0.66 & 0.70 & 0.86 & 0.50 & 0.48 \\
\hline $\mathrm{I}$ & $\S$ & $<0.01$ & $<0.01$ & $<0.01$ & $\S$ & $<0.01$ & $<0.01$ & $<0.01$ & $<0.01$ & $<0.01$ \\
\hline $\mathrm{K} 2 \mathrm{O}$ & 0.50 & 0.54 & 0.53 & 0.53 & 0.50 & 0.54 & 0.54 & 0.53 & 0.51 & 0.53 \\
\hline $\mathrm{Li}_{2} \mathrm{O}^{*}$ & 4.38 & 3.99 & 4.13 & 4.18 & 4.38 & 4.26 & 4.30 & 4.34 & 4.35 & 4.36 \\
\hline $\mathrm{MgO}$ & 0.99 & 1.15 & 0.96 & 0.99 & 0.99 & 0.93 & 1.00 & 0.96 & 0.94 & 0.89 \\
\hline $\mathrm{MnO}$ & $\S$ & 0.02 & 0.02 & 0.02 & $\S$ & 0.03 & 0.03 & 0.03 & 0.04 & 0.03 \\
\hline $\mathrm{Na}_{2} \mathrm{O}$ & 12.00 & 13.18 & 13.37 & 13.00 & 12.00 & 12.39 & 11.99 & 12.23 & 12.33 & 12.46 \\
\hline $\mathrm{NiO}$ & $\S$ & 0.02 & 0.01 & 0.02 & $\S$ & 0.02 & 0.02 & 0.01 & 0.01 & 0.02 \\
\hline $\mathrm{P}_{2} \mathrm{O}_{5}$ & 0.04 & 0.08 & 0.07 & 0.08 & 0.04 & 0.08 & 0.08 & 0.08 & 0.09 & 0.09 \\
\hline $\mathrm{PbO}$ & $\S$ & $<0.01$ & $<0.01$ & $<0.01$ & $\S$ & $<0.01$ & $<0.01$ & $<0.01$ & $<0.01$ & $<0.01$ \\
\hline $\mathrm{SiO}^{2}$ & 42.44 & 41.94 & 42.13 & 42.09 & 42.39 & 42.08 & 42.12 & 41.90 & 42.02 & 41.89 \\
\hline $\mathrm{SnO}_{2}$ & $\S$ & 0.01 & 0.01 & 0.01 & $\S$ & 0.01 & 0.01 & $<0.01$ & $<0.01$ & 0.01 \\
\hline $\mathrm{SO}_{3}$ & 1.40 & 1.19 & 1.20 & 1.20 & 1.50 & 1.25 & 1.30 & 1.29 & 1.31 & 1.35 \\
\hline $\mathrm{TiO}_{2}$ & $\S$ & 0.25 & 0.22 & 0.23 & $\S$ & 0.22 & 0.22 & 0.23 & 0.21 & 0.21 \\
\hline $\mathrm{V}_{2} \mathrm{O}_{5}$ & 2.52 & 2.64 & 2.64 & 2.66 & 2.51 & 2.74 & 2.79 & 2.73 & 2.76 & 2.78 \\
\hline $\mathrm{ZnO}$ & 2.93 & 3.00 & 2.88 & 2.93 & 2.93 & 2.99 & 2.96 & 2.91 & 2.93 & 2.95 \\
\hline $\mathrm{ZrO}_{2}$ & 3.91 & 3.64 & 3.53 & 3.53 & 3.90 & 3.67 & 3.71 & 3.72 & 3.67 & 3.55 \\
\hline Sum & 100.00 & 100.00 & 100.00 & 100.00 & 100.00 & \begin{tabular}{|l|}
100.00 \\
\end{tabular} & 100.00 & 100.00 & 100.00 & 100.00 \\
\hline
\end{tabular}

* - Target values calculated based on simple well-stirred tank model using DCP-AES analyzed boron and lithium concentrations in the first discharged glass sample

$\S$ - Not a target constituent

NA - not analyzed by XRF

“_“ sign for empty data field 
The Catholic University of America Vitreous State Laboratory

Table 4.2. XRF Analyzed Compositions for DM10 Discharged Glass Samples (wt\%) (continued).

\begin{tabular}{|c|c|c|c|c|c|c|c|c|c|c|c|}
\hline Formulation & \multicolumn{11}{|c|}{ ORPLG9 } \\
\hline Test & \multicolumn{8}{|c|}{ G1 } & \multicolumn{3}{|c|}{ G2 } \\
\hline Target $\mathrm{SO}_{3}$ & \multicolumn{8}{|c|}{$0.5 \%$} & \multicolumn{3}{|c|}{$0.3 \%$} \\
\hline Glass (kg) & - & 391.71 & 395.25 & \begin{tabular}{|l|}
398.93 \\
\end{tabular} & \begin{tabular}{|l|}
402.33 \\
\end{tabular} & 405.63 & 409.49 & 412.57 & - & \begin{tabular}{|l|}
415.07 \\
\end{tabular} & \begin{tabular}{|l|}
417.95 \\
\end{tabular} \\
\hline Constituent & Target & $\begin{array}{c}10 \mathrm{~A}-\mathrm{G}- \\
9 \mathrm{~B}\end{array}$ & $\begin{array}{c}10 \mathrm{~A}-\mathrm{G}- \\
14 \mathrm{~A}\end{array}$ & $\begin{array}{c}10 \mathrm{~A}-\mathrm{G}- \\
14 \mathrm{C}\end{array}$ & $\begin{array}{c}10 \mathrm{~A}-\mathrm{G}- \\
15 \mathrm{~A}\end{array}$ & $\begin{array}{c}10 \mathrm{~A}-\mathrm{G}- \\
15 \mathrm{C}\end{array}$ & $\begin{array}{c}10 \mathrm{~A}-\mathrm{G}- \\
18 \mathrm{~A}\end{array}$ & $\begin{array}{c}10 \mathrm{~A}-\mathrm{G}- \\
18 \mathrm{C}\end{array}$ & Target & $\begin{array}{c}10 \mathrm{~A}-\mathrm{G}- \\
23 \mathrm{~A}\end{array}$ & $\begin{array}{c}10 \mathrm{~A}-\mathrm{G}- \\
23 \mathrm{C}\end{array}$ \\
\hline $\mathrm{Al}_{2} \mathrm{O}_{3}$ & 6.74 & 7.80 & 7.28 & 6.97 & 6.87 & 6.69 & 6.70 & 6.51 & 6.75 & 6.52 & 6.47 \\
\hline $\mathrm{B}_{2} \mathrm{O}_{3}$ & 8.48 & 9.19 & 8.98 & 8.83 & 8.73 & 8.66 & 8.60 & 8.57 & 8.50 & 8.55 & 8.54 \\
\hline $\mathrm{CaO}$ & 2.69 & 7.44 & 6.48 & 5.00 & 4.29 & 3.99 & 3.74 & 3.54 & 2.69 & 3.26 & 3.29 \\
\hline $\mathrm{Cl}$ & 0.23 & 0.07 & 0.11 & 0.13 & 0.14 & 0.15 & 0.14 & 0.14 & 0.23 & 0.12 & 0.14 \\
\hline $\mathrm{Cr}_{2} \mathrm{O}_{3}{ }^{*}$ & 0.59 & 0.78 & 0.83 & 0.84 & 0.84 & 0.86 & 0.83 & 0.89 & 0.59 & 1.25 & 0.95 \\
\hline $\mathrm{Cs}_{2} \mathrm{O}$ & $\S$ & $<0.01$ & $<0.01$ & $<0.01$ & $<0.01$ & $<0.01$ & $<0.01$ & $<0.01$ & $\S$ & $<0.01$ & $<0.01$ \\
\hline $\mathrm{F}$ & 0.09 & NA & NA & NA & NA & NA & NA & NA & 0.09 & NA & NA \\
\hline $\mathrm{Fe}_{2} \mathrm{O}_{3}$ & 0.20 & 0.44 & 0.44 & 0.37 & 0.34 & 0.34 & 0.33 & 0.32 & 0.20 & 0.38 & 0.36 \\
\hline $\mathrm{I}$ & $\S$ & 0.04 & 0.05 & 0.07 & 0.07 & 0.08 & 0.07 & 0.09 & $\S$ & 0.10 & 0.11 \\
\hline $\mathrm{K} 2 \mathrm{O}$ & 5.74 & 2.15 & 3.18 & 4.02 & 4.39 & 4.66 & 4.78 & 5.13 & 5.75 & 5.07 & 5.35 \\
\hline $\mathrm{Li}_{2} \mathrm{O}^{*}$ & $\S$ & 2.90 & 2.04 & 1.41 & 1.00 & 0.72 & 0.49 & 0.36 & $\S$ & 0.28 & 0.21 \\
\hline $\mathrm{MgO}$ & 0.95 & 0.92 & 0.91 & 0.99 & 0.99 & 0.99 & 0.93 & 0.94 & 0.95 & 0.97 & 0.93 \\
\hline $\mathrm{MnO}$ & $\S$ & 0.02 & 0.02 & 0.02 & 0.01 & 0.01 & 0.01 & 0.01 & $\S$ & $<0.01$ & 0.01 \\
\hline $\mathrm{Na}_{2} \mathrm{O}$ & 21.00 & 14.69 & 15.36 & 17.82 & 19.25 & 19.52 & 20.40 & 19.90 & 21.00 & 21.02 & 19.79 \\
\hline $\mathrm{NiO}$ & 0.01 & 0.01 & 0.02 & 0.02 & 0.02 & 0.02 & 0.02 & 0.02 & 0.01 & 0.03 & 0.03 \\
\hline $\mathrm{P}_{2} \mathrm{O}_{5}$ & 0.14 & 0.12 & 0.14 & 0.15 & 0.17 & 0.17 & 0.18 & 0.18 & 0.14 & 0.17 & 0.18 \\
\hline $\mathrm{PbO}$ & 0.01 & $<0.01$ & 0.01 & 0.01 & 0.01 & 0.01 & 0.01 & 0.02 & 0.01 & 0.01 & 0.01 \\
\hline $\mathrm{SiO}^{2}$ & 40.76 & 41.84 & 41.53 & 40.94 & 40.87 & 40.87 & 40.55 & 40.59 & \begin{tabular}{|l|}
40.87 \\
\end{tabular} & 40.13 & 40.66 \\
\hline $\mathrm{SnO}_{2}$ & 2.83 & 1.09 & 1.75 & 2.26 & 2.36 & 2.58 & 2.66 & 3.07 & 2.83 & 2.85 & 3.10 \\
\hline $\mathrm{SO}_{3}$ & 0.50 & 1.02 & 0.90 & 0.73 & 0.67 & 0.66 & 0.59 & 0.58 & 0.30 & 0.57 & 0.47 \\
\hline $\mathrm{TiO}_{2}$ & $\S$ & 0.19 & 0.18 & 0.16 & 0.14 & 0.14 & 0.13 & 0.12 & $\S$ & 0.12 & 0.13 \\
\hline $\mathrm{V}_{2} \mathrm{O}_{5}$ & $\S$ & 1.95 & 1.49 & 0.95 & 0.66 & 0.54 & 0.44 & 0.34 & $\S$ & 0.26 & 0.23 \\
\hline $\mathrm{ZnO}$ & 3.39 & 3.11 & 3.41 & 3.34 & 3.28 & 3.32 & 3.35 & 3.48 & 3.40 & 3.37 & 3.61 \\
\hline $\mathrm{ZrO}_{2}$ & 5.66 & 4.23 & 4.88 & 4.95 & 4.90 & 5.02 & 5.05 & 5.21 & 5.67 & 4.95 & 5.44 \\
\hline Sum & 100.00 & \begin{tabular}{|l|}
100.00 \\
\end{tabular} & 100.00 & 100.00 & 100.00 & 100.00 & 100.00 & 100.00 & \begin{tabular}{|l|}
100.00 \\
\end{tabular} & 100.00 & \begin{tabular}{|l|}
100.00 \\
\end{tabular} \\
\hline
\end{tabular}


The Catholic University of America Vitreous State Laboratory

Table 4.2. XRF Analyzed Compositions for DM10 Discharged Glass Samples (wt\%) (continued).

\begin{tabular}{|c|c|c|c|c|c|c|c|c|c|c|}
\hline Formulation & \multicolumn{10}{|c|}{ ORPLG9 } \\
\hline Test & \multicolumn{8}{|c|}{ G2 } & \multicolumn{2}{|c|}{ G3 } \\
\hline Target $\mathrm{SO}_{3}$ & \multicolumn{8}{|c|}{$0.3 \%$} & \multicolumn{2}{|c|}{$0.2 \%$} \\
\hline Glass (kg) & - & 420.63 & 422.63 & 425.93 & 429.37 & 432.79 & 435.57 & 438.41 & - & 443.89 \\
\hline Constituent & Target & $\begin{array}{c}10 \mathrm{~A}-\mathrm{G}- \\
24 \mathrm{~A}\end{array}$ & \begin{tabular}{|c|}
$10 \mathrm{~A}-\mathrm{G}-$ \\
$24 \mathrm{C}$
\end{tabular} & \begin{tabular}{|c|}
$10 \mathrm{~A}-\mathrm{G}-$ \\
$25 \mathrm{~A}$
\end{tabular} & \begin{tabular}{|c|}
$10 \mathrm{~A}-\mathrm{G}-$ \\
$25 \mathrm{C}$
\end{tabular} & $\begin{array}{c}10 \mathrm{~A}-\mathrm{G}- \\
29 \mathrm{~B}\end{array}$ & \begin{tabular}{|c|}
$10 \mathrm{~A}-\mathrm{G}-$ \\
$29 \mathrm{D}$
\end{tabular} & $\begin{array}{c}10 \mathrm{~A}-\mathrm{G}- \\
30 \mathrm{~B}\end{array}$ & Target & \begin{tabular}{|c|}
$10 \mathrm{~A}-\mathrm{G}-$ \\
$33 \mathrm{~A}$
\end{tabular} \\
\hline $\mathrm{Al}_{2} \mathrm{O}_{3}$ & 6.75 & 6.47 & 6.39 & 6.54 & 6.39 & 6.28 & 6.44 & 6.41 & 6.76 & 6.37 \\
\hline $\mathrm{B}_{2} \mathrm{O}_{3}$ & 8.50 & 8.53 & 8.53 & 8.52 & 8.51 & 8.49 & 8.49 & 8.49 & 8.51 & 8.50 \\
\hline $\mathrm{CaO}$ & 2.69 & 3.16 & 3.08 & 2.93 & 2.86 & 2.91 & 2.81 & 2.84 & 2.70 & 2.83 \\
\hline $\mathrm{Cl}$ & 0.23 & 0.14 & 0.13 & 0.15 & 0.15 & 0.17 & 0.15 & 0.16 & 0.23 & 0.15 \\
\hline $\mathrm{Cr}_{2} \mathrm{O}_{3} *$ & 0.59 & 0.89 & 1.05 & 0.87 & 1.01 & 0.91 & 0.91 & 1.10 & 0.59 & 0.90 \\
\hline $\mathrm{Cs}_{2} \mathrm{O}$ & $\S$ & $<0.01$ & $<0.01$ & $<0.01$ & $<0.01$ & $<0.01$ & $<0.01$ & $<0.01$ & $\S$ & $<0.01$ \\
\hline $\mathrm{F}$ & 0.09 & NA & NA & NA & NA & NA & NA & NA & 0.09 & NA \\
\hline $\mathrm{Fe}_{2} \mathrm{O}_{3}$ & 0.20 & 0.31 & 0.32 & 0.30 & 0.30 & 0.31 & 0.30 & 0.30 & 0.20 & 0.30 \\
\hline $\mathrm{I}$ & $\S$ & 0.10 & 0.12 & 0.12 & 0.10 & 0.11 & 0.13 & 0.10 & $\S$ & 0.12 \\
\hline $\mathrm{K} 2 \mathrm{O}$ & 5.75 & 5.30 & 5.39 & 5.30 & 5.33 & 5.48 & 5.48 & 5.70 & 5.76 & 5.61 \\
\hline $\mathrm{Li}_{2} \mathrm{O}^{*}$ & $\S$ & 0.16 & 0.13 & 0.09 & 0.07 & 0.05 & 0.04 & 0.03 & $\S$ & 0.02 \\
\hline $\mathrm{MgO}$ & 0.95 & 0.99 & 0.93 & 1.00 & 0.98 & 0.96 & 0.93 & 0.92 & 0.96 & 0.91 \\
\hline $\mathrm{MnO}$ & $\S$ & 0.01 & $<0.01$ & 0.01 & 0.01 & 0.01 & 0.01 & $<0.01$ & $\S$ & 0.01 \\
\hline $\mathrm{Na}_{2} \mathrm{O}$ & 21.00 & 20.60 & 20.39 & 20.71 & 21.78 & 20.20 & 21.14 & 20.50 & 21.00 & 21.10 \\
\hline $\mathrm{NiO}$ & 0.01 & 0.03 & 0.03 & 0.03 & 0.03 & 0.02 & 0.03 & 0.03 & 0.01 & 0.02 \\
\hline $\mathrm{P}_{2} \mathrm{O}_{5}$ & 0.14 & 0.18 & 0.18 & 0.19 & 0.18 & 0.19 & 0.18 & 0.19 & 0.14 & 0.18 \\
\hline $\mathrm{PbO}$ & 0.01 & 0.01 & 0.01 & 0.02 & 0.02 & 0.01 & 0.02 & 0.02 & 0.01 & 0.02 \\
\hline $\mathrm{SiO}^{2}$ & 40.87 & 40.51 & 40.36 & 40.81 & 39.99 & 39.87 & 40.12 & 40.20 & 40.92 & 40.15 \\
\hline $\mathrm{SnO}_{2}$ & 2.83 & 3.08 & 3.28 & 3.22 & 3.10 & 3.41 & 3.41 & 3.49 & 2.84 & 3.40 \\
\hline $\mathrm{SO}_{3}$ & 0.30 & 0.41 & 0.41 & 0.37 & 0.35 & 0.35 & 0.33 & 0.34 & 0.20 & 0.30 \\
\hline $\mathrm{TiO}_{2}$ & $\S$ & 0.13 & 0.13 & 0.12 & 0.11 & 0.12 & 0.12 & 0.12 & $\S$ & 0.11 \\
\hline $\mathrm{V}_{2} \mathrm{O}_{5}$ & $\S$ & 0.19 & 0.16 & 0.12 & 0.10 & 0.08 & 0.07 & 0.06 & $\S$ & 0.06 \\
\hline $\mathrm{ZnO}$ & 3.40 & 3.51 & 3.55 & 3.38 & 3.41 & 3.58 & 3.49 & 3.57 & 3.40 & 3.53 \\
\hline $\mathrm{ZrO}_{2}$ & 5.67 & 5.29 & 5.44 & 5.21 & 5.21 & 5.55 & 5.42 & 5.44 & 5.68 & 5.41 \\
\hline Sum & 100.00 & 100.00 & 100.00 & 100.00 & 100.00 & 99.04 & 100.00 & 100.00 & 100.00 & 100.00 \\
\hline
\end{tabular}


The Catholic University of America Vitreous State Laboratory

Table 4.2. XRF Analyzed Compositions for DM10 Discharged Glass Samples (wt\%) (continued).

\begin{tabular}{|c|c|c|c|c|c|c|c|c|}
\hline Formulation & \multicolumn{8}{|c|}{ ORPLG9 } \\
\hline Test & \multicolumn{8}{|c|}{ G3 } \\
\hline Target $\mathrm{SO}_{3}$ & \multicolumn{8}{|c|}{$0.2 \%$} \\
\hline Glass (kg) & - & 446.15 & 448.97 & 451.63 & 454.01 & 456.41 & 458.97 & 462.91 \\
\hline Constituent & Target & $\begin{array}{c}\text { 10A-G- } \\
36 \mathrm{~A}\end{array}$ & $\begin{array}{c}10 \mathrm{~A}-\mathrm{G}- \\
37 \mathrm{~A}\end{array}$ & $\begin{array}{c}10 \mathrm{~A}-\mathrm{G}- \\
38 \mathrm{~B}\end{array}$ & $\begin{array}{c}\text { 10A-G- } \\
\text { 38D }\end{array}$ & $\begin{array}{c}\text { 10A-G- } \\
38 \mathrm{~F}\end{array}$ & $\begin{array}{c}\text { 10A-G- } \\
39 B\end{array}$ & $\begin{array}{c}\text { 10A-G- } \\
43 \mathrm{~B}\end{array}$ \\
\hline $\mathrm{Al}_{2} \mathrm{O}_{3}$ & 6.76 & 6.39 & 6.42 & 6.41 & 6.36 & 6.40 & 6.44 & 6.41 \\
\hline $\mathrm{B}_{2} \mathrm{O}_{3}$ & 8.51 & 8.50 & 8.50 & 8.51 & 8.51 & 8.51 & 8.51 & 8.51 \\
\hline $\mathrm{CaO}$ & 2.70 & 2.80 & 2.82 & 2.76 & 2.81 & 2.71 & 2.73 & 2.71 \\
\hline $\mathrm{Cl}$ & 0.23 & 0.15 & 0.16 & 0.16 & 0.16 & 0.16 & 0.16 & 0.16 \\
\hline $\mathrm{Cr}_{2} \mathrm{O}_{3}$ * & 0.59 & 1.07 & 1.04 & 0.91 & 0.99 & 0.87 & 0.91 & 0.92 \\
\hline $\mathrm{Cs}_{2} \mathrm{O}$ & $\S$ & $<0.01$ & $<0.01$ & $<0.01$ & $<0.01$ & $<0.01$ & $<0.01$ & $<0.01$ \\
\hline $\mathrm{F}$ & 0.09 & NA & NA & NA & NA & NA & NA & NA \\
\hline $\mathrm{Fe}_{2} \mathrm{O}_{3}$ & 0.20 & 0.31 & 0.31 & 0.30 & 0.32 & 0.29 & 0.30 & 0.31 \\
\hline $\mathrm{I}$ & $\S$ & 0.11 & 0.10 & 0.09 & 0.10 & 0.10 & 0.10 & 0.09 \\
\hline $\mathrm{K} 2 \mathrm{O}$ & 5.76 & 5.61 & 5.70 & 5.61 & 5.65 & 5.58 & 5.65 & 5.68 \\
\hline $\mathrm{Li}_{2} \mathrm{O}^{*}$ & $\S$ & 0.01 & 0.01 & 0.01 & 0.01 & $<0.01$ & $<0.01$ & $<0.01$ \\
\hline $\mathrm{MgO}$ & 0.96 & 0.92 & 0.94 & 1.01 & 1.01 & 1.05 & 1.04 & 0.95 \\
\hline $\mathrm{MnO}$ & $\S$ & $<0.01$ & 0.01 & 0.01 & $<0.01$ & 0.01 & 0.01 & $<0.01$ \\
\hline $\mathrm{Na}_{2} \mathrm{O}$ & 21.00 & 21.38 & 20.70 & 21.02 & 20.84 & 21.57 & 21.10 & 21.48 \\
\hline $\mathrm{NiO}$ & 0.01 & 0.03 & 0.03 & 0.03 & 0.03 & 0.02 & 0.03 & 0.03 \\
\hline $\mathrm{P}_{2} \mathrm{O}_{5}$ & 0.14 & 0.18 & 0.19 & 0.18 & 0.19 & 0.19 & 0.18 & 0.18 \\
\hline $\mathrm{PbO}$ & 0.01 & 0.02 & 0.02 & 0.02 & 0.02 & 0.02 & 0.02 & 0.01 \\
\hline $\mathrm{SiO}^{2}$ & 40.92 & 40.09 & 40.43 & 40.48 & 40.28 & 40.32 & 40.29 & 40.28 \\
\hline $\mathrm{SnO}_{2}$ & 2.84 & 3.18 & 3.18 & 3.19 & 3.27 & 3.07 & 3.21 & 3.07 \\
\hline $\mathrm{SO}_{3}$ & 0.20 & 0.30 & 0.29 & 0.26 & 0.26 & 0.22 & 0.23 & 0.21 \\
\hline $\mathrm{TiO}_{2}$ & $\S$ & 0.12 & 0.12 & 0.11 & 0.11 & 0.12 & 0.12 & 0.12 \\
\hline $\mathrm{V}_{2} \mathrm{O}_{5}$ & $\S$ & 0.05 & 0.04 & 0.03 & 0.05 & 0.03 & 0.03 & 0.02 \\
\hline $\mathrm{ZnO}$ & 3.40 & 3.45 & 3.54 & 3.48 & 3.52 & 3.43 & 3.52 & 3.48 \\
\hline $\mathrm{ZrO}_{2}$ & 5.68 & 5.32 & 5.44 & 5.42 & 5.52 & 5.32 & 5.45 & 5.38 \\
\hline Sum & 100.00 & 100.00 & 100.00 & 100.00 & 100.00 & 100.00 & 100.00 & 100.00 \\
\hline
\end{tabular}

* - Target values calculated based on simple well-stirred tank model using DCP-AES analyzed boron and lithium concentrations in the first discharged glass sample

$\S$ - Not a target constituent

NA - not analyzed by XRF

“_“ sign for empty data field 
The Catholic University of America Vitreous State Laboratory

Table 4.3. Comparison of Discharged Glass XRF Analysis and Target Compositions (wt\%).

\begin{tabular}{|c|c|c|c|c|c|c|c|c|}
\hline Formulation & \multicolumn{3}{|c|}{ ORPLA20 } & \multicolumn{5}{|c|}{ ORPLD6 } \\
\hline Test & \multirow[b]{2}{*}{ Target } & \multicolumn{2}{|c|}{ A2 } & \multirow[b]{2}{*}{ Target } & \multicolumn{2}{|c|}{ D 3} & \multicolumn{2}{|c|}{ D5 } \\
\hline Constituent & & $\begin{array}{c}\text { Y10-G- } \\
146 C\end{array}$ & \%Dev. & & $\begin{array}{c}\text { Z10-G- } \\
\text { 51D }\end{array}$ & \%Dev. & $\begin{array}{c}10 \mathrm{~A}-\mathrm{G}- \\
53 \mathrm{C}\end{array}$ & \%Dev. \\
\hline $\mathrm{Al}_{2} \mathrm{O}_{3}$ & 6.65 & 6.72 & 1.01 & 10.08 & 9.26 & -8.15 & 9.61 & -4.70 \\
\hline $\mathrm{B}_{2} \mathrm{O}_{3}$ & 8.74 & $8.73 *$ & $\mathrm{NC}$ & 9.84 & 9.84* & $\mathrm{NC}$ & $9.79 *$ & $\mathrm{NC}$ \\
\hline $\mathrm{CaO}$ & 3.32 & 3.56 & 7.24 & 7.88 & 7.92 & 0.43 & 7.41 & -5.99 \\
\hline $\mathrm{Cl}$ & 0.67 & 0.53 & $\mathrm{NC}$ & 0.35 & 0.30 & $\mathrm{NC}$ & 0.24 & $\mathrm{NC}$ \\
\hline $\mathrm{Cr}_{2} \mathrm{O}_{3}$ & 0.50 & 0.73 & $\mathrm{NC}$ & 0.50 & 0.71 & $\mathrm{NC}$ & 0.79 & $\mathrm{NC}$ \\
\hline Cs2O & $\S$ & $<0.01$ & $\mathrm{NC}$ & $\S$ & $<0.01$ & $\mathrm{NC}$ & $<0.01$ & $\mathrm{NC}$ \\
\hline $\mathrm{F}$ & $\S$ & NA & NC & 0.18 & NA & $\mathrm{NC}$ & NA & $\mathrm{NC}$ \\
\hline $\mathrm{Fe}_{2} \mathrm{O}_{3}$ & 0.19 & 0.35 & $\mathrm{NC}$ & 0.28 & 0.33 & $\mathrm{NC}$ & 0.82 & NC \\
\hline $\mathrm{I}$ & $\S$ & 0.10 & $\mathrm{NC}$ & $\S$ & $<0.01$ & $\mathrm{NC}$ & 0.01 & NC \\
\hline $\mathrm{K}_{2} \mathrm{O}$ & 0.53 & 0.56 & NC & 0.17 & 0.20 & $\mathrm{NC}$ & 0.37 & $\mathrm{NC}$ \\
\hline $\mathrm{Li}_{2} \mathrm{O}$ & $\S$ & NA & $\mathrm{NC}$ & $\S$ & NA & $\mathrm{NC}$ & NA & $\mathrm{NC}$ \\
\hline $\mathrm{MgO}$ & 0.92 & 0.95 & $\mathrm{NC}$ & 1.00 & 0.75 & $\mathrm{NC}$ & 0.81 & NC \\
\hline $\mathrm{MnO}$ & $\S$ & 0.01 & $\mathrm{NC}$ & $\S$ & $<0.01$ & $\mathrm{NC}$ & 0.03 & $\mathrm{NC}$ \\
\hline $\mathrm{Na} 2 \mathrm{O}$ & 24.00 & 23.09 & -3.79 & 22.00 & 23.33 & 6.05 & 21.94 & -0.29 \\
\hline $\mathrm{NiO}$ & $\S$ & 0.09 & NC & 0.04 & 0.18 & $\mathrm{NC}$ & 0.05 & $\mathrm{NC}$ \\
\hline $\mathrm{P}_{2} \mathrm{O}_{5}$ & $\S$ & 0.04 & $\mathrm{NC}$ & 0.30 & 0.37 & $\mathrm{NC}$ & 0.39 & $\mathrm{NC}$ \\
\hline $\mathrm{PbO}$ & $\S$ & 0.01 & NC & 0.01 & 0.02 & $\mathrm{NC}$ & 0.02 & $\mathrm{NC}$ \\
\hline $\mathrm{SiO}_{2}$ & 42.33 & 42.78 & 1.05 & 37.19 & 36.68 & -1.36 & 37.02 & -0.46 \\
\hline $\mathrm{SnO}_{2}$ & 2.74 & 2.87 & 4.75 & $\S$ & 0.02 & $\mathrm{NC}$ & 0.13 & $\mathrm{NC}$ \\
\hline $\mathrm{SO}_{3}$ & 0.70 & 0.61 & $\mathrm{NC}$ & 1.30 & 1.27 & $\mathrm{NC}$ & 1.25 & $\mathrm{NC}$ \\
\hline $\mathrm{TiO}_{2}$ & $\S$ & 0.05 & $\mathrm{NC}$ & $\S$ & 0.19 & $\mathrm{NC}$ & 0.20 & $\mathrm{NC}$ \\
\hline $\mathrm{V}_{2} \mathrm{O}_{5}$ & $\S$ & 0.01 & $\mathrm{NC}$ & 1.96 & 2.15 & 10.01 & 2.16 & 10.13 \\
\hline $\mathrm{ZnO}$ & 2.74 & 2.87 & 4.75 & 2.96 & 2.99 & 1.04 & 3.11 & 5.11 \\
\hline $\mathrm{ZrO}_{2}$ & 5.96 & 5.35 & -10.24 & 3.98 & 3.50 & -12.03 & 3.88 & -2.45 \\
\hline Sum & 100.00 & 100.00 & $\mathrm{NC}$ & 100.00 & 100.00 & $\mathrm{NC}$ & 100.00 & $\mathrm{NC}$ \\
\hline Sulfate? & - & No & - & - & No & - & Yes & - \\
\hline
\end{tabular}

* - Target composition calculated based actual proportion of meter feed residues after test $\S$ - Not a target constituent

NA - Not analyzed

NC - Not calculated

“_“ sign for empty data field 
Table 4.3. Comparison of Discharged Glass XRF Analysis and Target Compositions (wt\%) (continued).

\begin{tabular}{|c|c|c|c|c|c|c|c|c|c|}
\hline \multirow{3}{*}{$\begin{array}{c}\text { Formulation } \\
\text { Test } \\
\text { Constituent }\end{array}$} & \multicolumn{6}{|c|}{ ORPLF7 } & \multicolumn{3}{|c|}{ ORPLG9 } \\
\hline & \multirow[b]{2}{*}{ Target } & \multicolumn{2}{|c|}{ F4 } & \multirow[b]{2}{*}{ Target } & \multicolumn{2}{|c|}{ F6 } & \multirow[b]{2}{*}{ Target } & \multicolumn{2}{|c|}{ G3 } \\
\hline & & $\begin{array}{c}\text { Z10-G- } \\
122 B \\
\end{array}$ & \%Dev. & & $\begin{array}{c}\text { Z10-G- } \\
153 B\end{array}$ & \%Dev. & & \begin{tabular}{|c|}
$10 \mathrm{~A}-\mathrm{G}-$ \\
$43 \mathrm{~B}$
\end{tabular} & \%Dev. \\
\hline $\mathrm{Al}_{2} \mathrm{O}_{3}$ & 8.72 & 8.18 & -6.18 & 8.65 & 8.37 & -3.19 & 6.76 & 6.41 & -5.25 \\
\hline $\mathrm{B}_{2} \mathrm{O}_{3} *$ & 9.63 & 9.63 & NC & 9.56 & 9.55 & $\mathrm{NC}$ & 8.51 & 8.51 & $\mathrm{NC}$ \\
\hline $\mathrm{CaO}$ & 9.86 & 9.95 & 0.97 & 9.78 & 9.66 & -1.23 & 2.70 & 2.71 & 0.53 \\
\hline $\mathrm{Cl}$ & 0.01 & 0.01 & $\mathrm{NC}$ & 0.01 & 0.01 & $\mathrm{NC}$ & 0.23 & 0.16 & NC \\
\hline $\mathrm{Cr}_{2} \mathrm{O}_{3}$ & 0.57 & 0.81 & NC & 0.56 & 0.80 & NC & 0.59 & 0.92 & $\mathrm{NC}$ \\
\hline Cs2O & $\S$ & $<0.01$ & NC & $\S$ & $<0.01$ & NC & $\S$ & $<0.01$ & NC \\
\hline $\mathrm{F}$ & 0.08 & NA & NC & 0.08 & NA & NC & 0.09 & NA & $\mathrm{NC}$ \\
\hline $\mathrm{Fe}_{2} \mathrm{O}_{3}$ & 0.23 & 0.43 & $\mathrm{NC}$ & 0.23 & 0.48 & NC & 0.20 & 0.31 & $\mathrm{NC}$ \\
\hline $\mathrm{I}$ & $\S$ & $<0.01$ & NC & $\S$ & $<0.01$ & NC & $\S$ & 0.09 & $\mathrm{NC}$ \\
\hline $\mathrm{K}_{2} \mathrm{O}$ & 0.50 & 0.53 & NC & 0.50 & 0.53 & NC & 5.76 & 5.68 & -1.32 \\
\hline $\mathrm{Li}_{2} \mathrm{O}$ & 4.41 & 4.41 & NC & 4.38 & 4.36 & NC & $\S$ & NA & NC \\
\hline $\mathrm{MgO}$ & 0.99 & 1.00 & NC & 0.99 & 0.89 & NC & 0.96 & 0.95 & $\mathrm{NC}$ \\
\hline $\mathrm{MnO}$ & $\S$ & 0.01 & NC & $\S$ & 0.03 & NC & $\S$ & $<0.01$ & NC \\
\hline $\mathrm{Na} 2 \mathrm{O}$ & 12.00 & 11.74 & -2.15 & 12.00 & 12.46 & 3.84 & 21.00 & 21.48 & 2.28 \\
\hline $\mathrm{NiO}$ & $\S$ & 0.01 & NC & $\S$ & 0.02 & $\mathrm{NC}$ & 0.01 & 0.03 & NC \\
\hline $\mathrm{P}_{2} \mathrm{O}_{5}$ & 0.04 & 0.08 & NC & 0.04 & 0.09 & NC & 0.14 & 0.18 & $\mathrm{NC}$ \\
\hline $\mathrm{PbO}$ & $\S$ & 0.00 & NC & $\S$ & $<0.01$ & NC & 0.01 & 0.01 & NC \\
\hline $\mathrm{SiO}_{2}$ & 42.73 & 42.63 & -0.26 & 42.39 & 41.89 & -1.18 & 40.92 & 40.28 & -1.57 \\
\hline $\mathrm{SnO}_{2}$ & $\S$ & 0.01 & NC & $\S$ & 0.01 & $\mathrm{NC}$ & 2.84 & 3.07 & 8.29 \\
\hline $\mathrm{SO}_{3}$ & 0.80 & 0.76 & NC & 1.50 & 1.35 & NC & 0.20 & 0.21 & NC \\
\hline $\mathrm{TiO}_{2}$ & $\S$ & 0.19 & NC & $\S$ & 0.21 & NC & $\S$ & 0.12 & $\mathrm{NC}$ \\
\hline $\mathrm{V}_{2} \mathrm{O}_{5}$ & 2.53 & 2.85 & 12.45 & 2.51 & 2.78 & 10.74 & $\S$ & 0.02 & NC \\
\hline $\mathrm{ZnO}$ & 2.95 & 3.03 & 2.70 & 2.93 & 2.95 & 0.96 & 3.40 & 3.48 & 2.40 \\
\hline $\mathrm{ZrO}_{2}$ & 3.93 & 3.74 & -4.92 & 3.90 & 3.55 & -9.14 & 5.68 & 5.38 & -5.22 \\
\hline Sum & 100.00 & 100.00 & $\mathrm{NC}$ & 100.00 & 100.00 & $\mathrm{NC}$ & 100.00 & 100.00 & NC \\
\hline Sulfate? & - & No & - & - & No & - & - & Yes & - \\
\hline
\end{tabular}


The Catholic University of America Vitreous State Laboratory

Table 4.4. XRF and DCP Analyzed Compositions for Selected Discharged Glass Samples During DM10 ORP LAW Tests (wt\%).

\begin{tabular}{|c|c|c|c|c|c|c|c|c|c|c|}
\hline Formulation & \multicolumn{5}{|c|}{ ORPLA20 } & \multicolumn{5}{|c|}{ ORPLD6 } \\
\hline Test & \multicolumn{2}{|c|}{ A1 } & \multicolumn{3}{|c|}{ A2 } & \multirow{4}{*}{ Target } & \multicolumn{2}{|c|}{ D4 } & \multicolumn{2}{|c|}{ D5 } \\
\hline Sample ID & \multicolumn{2}{|c|}{ Y10-G-133C } & \multicolumn{3}{|c|}{ Y10-G-146C } & & \multirow{2}{*}{\multicolumn{2}{|c|}{$\begin{array}{c}\text { Z10-G-60C } \\
\text { End of D4 }\end{array}$}} & \multirow{2}{*}{\multicolumn{2}{|c|}{$\begin{array}{c}10 \mathrm{~A}-\mathrm{G}-53 \mathrm{C} \\
\text { End of D5 }\end{array}$}} \\
\hline Sample Info. & \multicolumn{2}{|c|}{\begin{tabular}{|l} 
First Discharge \\
\end{tabular}} & \multicolumn{3}{|c|}{ End of A2 } & & & & & \\
\hline Constituent & XRF & DCP & Target & XRF & DCP & & XRF & DCP & XRF & $\overline{D C P}$ \\
\hline $\mathrm{Al}_{2} \mathrm{O}_{3}$ & 8.35 & 7.18 & 6.65 & 6.72 & 6.20 & 10.09 & 8.73 & 7.94 & 9.61 & 9.62 \\
\hline $\mathrm{B}_{2} \mathrm{O}_{3}$ & 7.93* & 7.93 & 8.74 & $8.73^{* *}$ & 8.30 & 9.85 & $9.85^{* *}$ & 9.47 & $9.79 * *$ & 10.03 \\
\hline $\mathrm{CaO}$ & 2.75 & 3.03 & 3.32 & 3.56 & 3.56 & 7.89 & 8.29 & 6.72 & 7.41 & 6.81 \\
\hline $\mathrm{Cl}$ & 0.31 & NA & 0.67 & 0.53 & NA & 0.35 & 0.31 & NA & 0.24 & NA \\
\hline $\mathrm{Cr}_{2} \mathrm{O}_{3}$ & 0.42 & 0.45 & 0.50 & 0.73 & 0.58 & 0.50 & 0.85 & 0.65 & 0.79 & 0.63 \\
\hline $\mathrm{Cs}_{2} \mathrm{O}$ & 0.11 & NA & $\S$ & $<0.01$ & NA & $\S$ & $<0.01$ & NA & $<0.01$ & NA \\
\hline $\mathrm{F}$ & NA & NA & $\S$ & NA & NA & 0.18 & NA & NA & NA & NA \\
\hline $\mathrm{Fe}_{2} \mathrm{O}_{3}$ & 3.12 & 2.20 & 0.19 & 0.35 & 0.32 & 0.28 & 0.58 & 0.55 & 0.82 & 1.05 \\
\hline $\mathrm{I}$ & 0.06 & NA & $\S$ & 0.10 & NA & $\S$ & $<0.01$ & NA & 0.01 & NA \\
\hline $\mathrm{K} 2 \mathrm{O}$ & 0.52 & 0.61 & 0.53 & 0.56 & 0.62 & 0.17 & 0.22 & 0.25 & 0.37 & 0.46 \\
\hline $\mathrm{Li}_{2} \mathrm{O}$ & $0.13^{*}$ & 0.13 & $\S$ & $<0.01^{* *}$ & 0.04 & $\S$ & $<0.01^{* *}$ & 0.06 & $<0.01 * *$ & 0.06 \\
\hline $\mathrm{MgO}$ & 1.51 & 1.43 & 0.92 & 0.95 & 0.98 & 1.00 & 0.52 & 0.61 & 0.81 & 0.93 \\
\hline $\mathrm{MnO}$ & 0.02 & 0.02 & $\S$ & 0.01 & 0.01 & $\S$ & 0.01 & 0.01 & 0.03 & 0.03 \\
\hline $\mathrm{Na}_{2} \mathrm{O}$ & 20.65 & 19.40 & 24.00 & 23.09 & 21.80 & 22.00 & 23.17 & 22.11 & 21.94 & 18.70 \\
\hline $\mathrm{NiO}$ & 0.46 & 0.34 & $\S$ & 0.09 & 0.09 & 0.04 & 0.24 & 0.23 & 0.05 & 0.07 \\
\hline $\mathrm{P}_{2} \mathrm{O}_{5}$ & 0.34 & 0.36 & $\S$ & 0.04 & 0.01 & 0.30 & 0.39 & 0.37 & 0.39 & 0.37 \\
\hline $\mathrm{PbO}$ & $<0.01$ & 0.02 & $\S$ & 0.01 & 0.02 & 0.01 & 0.02 & 0.04 & 0.02 & 0.03 \\
\hline $\mathrm{SiO}_{2}$ & \begin{tabular}{|l|}
43.68 \\
\end{tabular} & 41.09 & 42.33 & 42.78 & 42.39 & 37.24 & 36.80 & 35.62 & 37.02 & 35.51 \\
\hline $\mathrm{SnO}_{2}$ & 1.53 & 2.09 & 2.74 & 2.87 & 2.87 & $\S$ & 0.02 & 0.02 & 0.13 & 0.14 \\
\hline $\mathrm{SO}_{3}$ & 0.31 & NA & 0.70 & 0.61 & NA & 1.20 & 1.26 & NA & 1.25 & NA \\
\hline $\mathrm{TiO}_{2}$ & 0.40 & 0.29 & $\S$ & 0.05 & 0.05 & $\S$ & 0.16 & 0.15 & 0.20 & 0.23 \\
\hline $\mathrm{V}_{2} \mathrm{O}_{5}$ & 0.42 & 0.30 & $\S$ & 0.01 & 0.03 & 1.96 & 2.27 & 2.12 & 2.16 & 2.08 \\
\hline $\mathrm{ZnO}$ & 2.41 & 2.52 & 2.74 & 2.87 & 2.76 & 2.96 & 3.21 & 2.88 & 3.11 & 3.12 \\
\hline $\mathrm{ZrO}_{2}$ & 4.59 & 4.55 & 5.96 & 5.35 & 4.92 & 3.98 & 3.11 & 2.56 & 3.88 & 3.63 \\
\hline Sum & 100.00 & 93.94 & 100.00 & 100.00 & 95.55 & 100.00 & 100.00 & 92.36 & 100.00 & 93.50 \\
\hline
\end{tabular}

* - DCP analyzed results

** - Target values calculated based on simple well-stirred tank model using DCP-AES analyzed boron and lithium concentrations in the first discharged glass sample

$\S$ - Not a target constituent

NA - not analyzed by XRF 
The Catholic University of America Vitreous State Laboratory

\section{XRF and DCP Analyzed Compositions for Selected Discharged Glass Samples During DM10 ORP LAW Tests (wt\%) (continued).}

\begin{tabular}{|c|c|c|c|c|c|c|c|c|c|c|c|}
\hline Formulation & \multicolumn{8}{|c|}{ ORPLF7 } & \multirow{2}{*}{\multicolumn{3}{|c|}{$\begin{array}{c}\text { ORPLG9 } \\
\text { G3 }\end{array}$}} \\
\hline Test & \multicolumn{2}{|c|}{ F1 } & \multicolumn{3}{|c|}{ F4 } & \multicolumn{3}{|c|}{ F6 } & & & \\
\hline Sample ID & \multicolumn{2}{|c|}{ Z10-G-86A } & \multicolumn{3}{|c|}{ Z10-G-122B } & \multicolumn{3}{|c|}{ Z10-G-153B } & \multicolumn{3}{|c|}{ 10A-G-43B } \\
\hline Sample Info. & \multicolumn{2}{|c|}{ First discharge } & \multicolumn{3}{|c|}{ End of F4 } & \multicolumn{3}{|c|}{ End of F6 } & \multicolumn{3}{|c|}{$\frac{10 \mathrm{~A}-\mathrm{G}-43 \mathrm{~B}}{\text { End of } \mathrm{G} 3}$} \\
\hline Constituent & XRF & DCP & Target & XRF & DCP & Target & XRF & DCP & Target & XRF & DCP \\
\hline $\mathrm{Al}_{2} \mathrm{O}_{3}$ & 7.12 & 6.73 & 8.72 & 8.18 & 7.82 & 8.65 & 8.37 & 7.73 & 6.76 & 6.41 & 6.56 \\
\hline $\mathrm{B}_{2} \mathrm{O}_{3}$ & 8.88* & 8.88 & 9.63 & $9.63^{* *}$ & 9.36 & 9.56 & $9.55 * *$ & 9.57 & 8.51 & $8.51^{* *}$ & 8.15 \\
\hline $\mathrm{CaO}$ & 5.10 & 4.57 & 9.86 & 9.95 & 8.70 & 9.78 & 9.66 & 8.69 & 2.70 & 2.71 & 2.80 \\
\hline $\mathrm{Cl}$ & 0.08 & NA & 0.01 & 0.01 & NA & 0.01 & 0.01 & NA & 0.23 & 0.16 & NA \\
\hline $\mathrm{Cr}_{2} \mathrm{O}_{3} *$ & 0.48 & 0.37 & 0.57 & 0.81 & 0.65 & 0.56 & 0.80 & 0.66 & 0.59 & 0.92 & 0.71 \\
\hline $\mathrm{Cs}_{2} \mathrm{O}$ & 0.07 & NA & $\S$ & $<0.01$ & NA & $\S$ & $<0.01$ & NA & $\S$ & $<0.01$ & NA \\
\hline $\mathrm{F}$ & NA & NA & 0.08 & NA & NA & 0.08 & $\mathrm{NA}$ & NA & 0.09 & NA & NA \\
\hline $\mathrm{Fe}_{2} \mathrm{O}_{3}$ & 4.41 & 3.99 & 0.23 & 0.43 & 0.42 & 0.23 & 0.48 & 0.50 & 0.20 & 0.31 & 0.31 \\
\hline $\mathrm{I}$ & $<0.01$ & NA & $\S$ & $<0.01$ & NA & $\S$ & $<0.01$ & NA & $\S$ & 0.09 & NA \\
\hline $\mathrm{K} 2 \mathrm{O}$ & 0.45 & 0.53 & 0.50 & 0.53 & 0.61 & 0.50 & 0.53 & 0.61 & 5.76 & 5.68 & 5.48 \\
\hline $\mathrm{Li}_{2} \mathrm{O}^{*}$ & $1.79 *$ & 1.79 & 4.41 & $4.41 * *$ & 4.47 & 4.38 & $4.36 * *$ & 4.37 & $\S$ & $<0.01$ ** & 0.05 \\
\hline $\mathrm{MgO}$ & 1.60 & 1.73 & 0.99 & 1.00 & 1.07 & 0.99 & 0.89 & 0.98 & 0.96 & 0.95 & 1.14 \\
\hline $\mathrm{MnO}$ & 0.02 & 0.02 & $\S$ & 0.01 & 0.01 & $\S$ & 0.03 & 0.03 & $\S$ & $<0.01$ & 0.01 \\
\hline $\mathrm{Na}_{2} \mathrm{O}$ & 16.95 & 15.17 & 12.00 & \begin{tabular}{|l|}
11.74 \\
\end{tabular} & 10.30 & 12.00 & 12.46 & 10.53 & 21.00 & 21.48 & 17.86 \\
\hline $\mathrm{NiO}$ & 0.21 & 0.19 & $\S$ & 0.01 & 0.03 & $\S$ & 0.02 & 0.03 & 0.01 & 0.03 & 0.03 \\
\hline $\mathrm{P}_{2} \mathrm{O}_{5}$ & 0.07 & 0.07 & 0.04 & 0.08 & $<0.01$ & 0.04 & 0.09 & $<0.01$ & 0.14 & 0.18 & 0.20 \\
\hline $\mathrm{PbO}$ & $<0.01$ & 0.00 & $\S$ & $<0.01$ & 0.02 & $\S$ & $<0.01$ & $<0.01$ & 0.01 & 0.01 & 0.01 \\
\hline $\mathrm{SiO}_{2}$ & \begin{tabular}{|l|}
43.14 \\
\end{tabular} & 41.36 & \begin{tabular}{|l|}
42.73 \\
\end{tabular} & 42.63 & 41.15 & \begin{tabular}{|l|}
42.39 \\
\end{tabular} & \begin{tabular}{|l|}
41.89 \\
\end{tabular} & \begin{tabular}{|l|}
40.79 \\
\end{tabular} & \begin{tabular}{|l|}
40.92 \\
\end{tabular} & 40.28 & 38.70 \\
\hline $\mathrm{SnO}_{2}$ & 0.02 & 0.03 & $\S$ & 0.01 & 0.05 & $\S$ & 0.01 & 0.05 & 2.84 & 3.07 & 3.02 \\
\hline $\mathrm{SO}_{3}$ & 0.81 & NA & 0.80 & 0.76 & NA & 1.50 & 1.35 & NA & 0.20 & 0.21 & NA \\
\hline $\mathrm{TiO}_{2}$ & 0.51 & 0.52 & $\S$ & 0.19 & 0.20 & $\S$ & 0.21 & 0.23 & $\S$ & 0.12 & 0.15 \\
\hline $\mathrm{V}_{2} \mathrm{O}_{5}$ & 1.96 & 1.81 & 2.53 & 2.85 & 2.60 & 2.51 & 2.78 & 2.57 & $\S$ & 0.02 & 0.03 \\
\hline $\mathrm{ZnO}$ & 3.06 & 3.19 & 2.95 & 3.03 & 2.78 & 2.93 & 2.95 & 2.84 & 3.40 & 3.48 & 3.45 \\
\hline $\mathrm{ZrO}_{2}$ & 3.28 & 3.13 & 3.93 & 3.74 & 3.85 & 3.90 & 3.55 & 3.67 & 5.68 & 5.38 & 5.39 \\
\hline Sum & 100.00 & 94.08 & 100.00 & 100.00 & 94.09 & 100.00 & 100.00 & 93.85 & 100.00 & 100.00 & 94.05 \\
\hline
\end{tabular}

* - DCP analyzed results

** - Target values calculated based on simple well-stirred tank model using DCP-AES analyzed boron and lithium concentrations in the first discharged glass sample

$\S$ - Not a target constituent

NA - not analyzed by XRF 
Table 4.5. Listing of Dip Samples and Presence of Sulfate Layer During DM10 Melter Tests.

\begin{tabular}{|c|c|c|c|c|c|c|c|}
\hline \multirow{2}{*}{ Test } & \multicolumn{3}{|c|}{ Target (wt.\%) } & \multirow{2}{*}{$\begin{array}{c}\text { Sampling } \\
\text { Date }\end{array}$} & \multirow{2}{*}{ Sample Name } & \multirow{2}{*}{$\begin{array}{c}\text { Sample } \\
\text { Location }\end{array}$} & \multirow{2}{*}{$\begin{array}{c}\text { Secondary } \\
\text { Phase } \\
\text { Observed }\end{array}$} \\
\hline & $\mathrm{SO}_{3}$ & $\mathrm{Cl}$ & $\mathrm{Cr}_{2} \mathrm{O}_{3}$ & & & & \\
\hline \multirow{3}{*}{ Before A1 } & \multirow{6}{*}{0.50} & \multirow{6}{*}{0.67} & \multirow{6}{*}{0.50} & \multirow{6}{*}{$10 / 15 / 2008$} & Y10-D-133A & North & No \\
\hline & & & & & Y10-D-133B & East & No \\
\hline & & & & & Y10-D-133C & South & No \\
\hline \multirow{3}{*}{ End of A1 } & & & & & Y10-D-136A & North & No \\
\hline & & & & & Y10-D-136B & South & No \\
\hline & & & & & Y10-D-136C & East & No \\
\hline \multirow{3}{*}{ End of A2 } & \multirow{3}{*}{0.70} & \multirow{3}{*}{0.67} & \multirow{3}{*}{0.50} & \multirow{6}{*}{$10 / 16 / 2008$} & Y10-D-146A & North & No \\
\hline & & & & & Y10-D-146B & East & No \\
\hline & & & & & Y10-D-146C & South & No \\
\hline \multirow{6}{*}{ End of A3 } & \multirow{6}{*}{0.90} & \multirow{6}{*}{0.67} & \multirow{6}{*}{0.50} & & Y10-D-153A & North & Yes \\
\hline & & & & & Y10-D-153B & East & Yes \\
\hline & & & & & Y10-D-153C & South & Yes \\
\hline & & & & & Y10-D-154A & NA & Yes \\
\hline & & & & & Y10-D-154B & NA & Yes \\
\hline & & & & & Y10-D-155A & NA & No \\
\hline \multirow{5}{*}{ End of A4 } & & & & 10/17/2008 & Z10-D-10A & North & Yes \\
\hline & & & & $10 / 1 / / 2008$ & Z10-D-10B & East & Yes \\
\hline & 0.80 & 0.67 & 0.50 & & Z10-D-10C & South & Yes \\
\hline & & & & & Z10-D-11A & East & Yes \\
\hline & & & & & Z10-D-11B & NA & No \\
\hline & & & & & Z10-D-35A & North & No \\
\hline End of D1 & 0.90 & 0.35 & 0.35 & 10/22/2008 & Z10-D-35B & East & No \\
\hline & & & & & Z10-D-35C & South & No \\
\hline & & & & & Z10-D-44A & East & No \\
\hline End of D2 & 1.10 & 0.35 & 0.50 & & Z10-D-44B & North & No \\
\hline & & & & & Z10-D-44C & South & No \\
\hline & & & & $10 / 23 / 2008$ & Z10-D-53A & North & Yes \\
\hline & & & & $10 / 23 / 2008$ & Z10-D-53B & East & Yes \\
\hline End of D3 & 1.30 & 0.35 & 0.50 & & Z10-D-53C & South & Yes \\
\hline & & & & & Z10-D-53D & South & Yes \\
\hline & & & & & Z10-D-53E & South & No \\
\hline & & & & & Z10-D-61A & North & No \\
\hline End of D4 & 1.20 & 0.35 & 0.50 & $10 / 24 / 2008$ & Z10-D-61B & East & No \\
\hline & & & & & Z10-D-61C & South & No \\
\hline & & & & & 10A-D-57A & North & Yes \\
\hline End of D5 & 1.20 & 0.35 & 0.50 & $1 / 16 / 2009$ & 10A-D-57B & East & Yes \\
\hline & & & & & 10A-D-57C & South & Yes \\
\hline & & & & & Z10-D-84A & $\begin{array}{c}\text { South- } \\
\text { East }\end{array}$ & No \\
\hline Before F1 & & & & $1 / 5 / 2009$ & Z10-D-84B & North & No \\
\hline & & & & & Z10-D-84C & South & No \\
\hline & 1.60 & 0.01 & 0.56 & & Z10-D-90A & North & No \\
\hline & & & & 1/6/2009 & Z10-D-90B & East & Yes \\
\hline End of F1 & & & & $1 / 6 / 2009$ & Z10-D-90C & South & No \\
\hline & & & & & Z10-D-90D & East & Yes \\
\hline
\end{tabular}

NA : Not Applicable 
Table 4.5. Listing of Dip Samples and Presence of Sulfate Layer During DM10 Melter Tests (continued).

\begin{tabular}{|c|c|c|c|c|c|c|c|}
\hline \multirow{2}{*}{ Test } & \multicolumn{3}{|c|}{ Target (wt.\%) } & \multirow{2}{*}{$\begin{array}{c}\text { Sampling } \\
\text { Date }\end{array}$} & \multirow{2}{*}{ Sample Name } & \multirow{2}{*}{$\begin{array}{c}\text { Sample } \\
\text { Location }\end{array}$} & \multirow{2}{*}{$\begin{array}{c}\text { Secondary } \\
\text { Phase } \\
\text { Observed }\end{array}$} \\
\hline & $\mathrm{SO}_{3}$ & $\mathrm{Cl}$ & $\mathrm{Cr}_{2} \mathrm{O}_{3}$ & & & & \\
\hline \multirow{3}{*}{ End of F1 } & \multirow{3}{*}{1.60} & \multirow{3}{*}{0.01} & \multirow{3}{*}{0.56} & \multirow{3}{*}{ 1/6/2009 } & Z10-D-90E & East & Yes \\
\hline & & & & & Z10-D-91A & East & Yes \\
\hline & & & & & Z10-D-95A & East & No \\
\hline \multirow{4}{*}{ End of F2 } & \multirow{4}{*}{1.40} & \multirow{4}{*}{0.01} & \multirow{4}{*}{0.56} & \multirow{4}{*}{ 1/7/2009 } & Z10-D-103A & North & No \\
\hline & & & & & Z10-D-103B & East & Slight \\
\hline & & & & & Z10-D-103C & South & No \\
\hline & & & & & Z10-D-103D & East & No \\
\hline \multirow{4}{*}{ End of F3 } & \multirow{4}{*}{1.20} & \multirow{4}{*}{0.01} & \multirow{4}{*}{0.57} & \multirow{4}{*}{ 1/7/2009 } & Z10-D-112A & North & No \\
\hline & & & & & Z10-D-112B & East & No \\
\hline & & & & & Z10-D-112A & South & No \\
\hline & & & & & Z10-D-112D & South & No \\
\hline \multirow{3}{*}{ End of F4 } & \multirow{3}{*}{0.8} & \multirow{3}{*}{0.01} & \multirow{3}{*}{0.57} & \multirow{3}{*}{ 1/8/2009 } & Z10-D-123A & North & No \\
\hline & & & & & Z10-D-123B & East & No \\
\hline & & & & & Z10-D-123C & South & No \\
\hline Before F5 & & & & $1 / 12 / 2009$ & Z10-D-140A & East & No \\
\hline \multirow{3}{*}{ End of F5 } & & & & & Z10-D-143A & North & No \\
\hline & 1.4 & 0.01 & 0.57 & 1/13/2009 & Z10-D-143B & East & No \\
\hline & & & & & Z10-D-143C & South & No \\
\hline & & & & & Z10-D-153A & North & No \\
\hline End of F6 & 1.5 & 0.01 & 0.56 & 1/13/2009 & Z10-D-153B & East & No \\
\hline & & & & & Z10-D-153C & South & No \\
\hline & & & & & 10A-D-19A & North & No \\
\hline & & & & & 10A-D-19B & East & Yes \\
\hline & & & & & 10A-D-19C & South & No \\
\hline End of G1 & 0.5 & 0.23 & 0.59 & 1/14/2009 & 10A-D-19D & East & Yes \\
\hline & & & & & 10A-D-19F & East & Yes \\
\hline & & & & & 10A-D-21A & East & No \\
\hline & & & & & 10A-D-30A & North & No \\
\hline & & 023 & 059 & & 10A-D-30B & East & Yes \\
\hline End of G2 & 0.3 & 0.23 & 0.59 & 1/14/2008 & 10A-D-30C & South & No \\
\hline & & & & & 10A-D-32D & East & No \\
\hline & & & & & 10A-D-43A & North & Yes \\
\hline Fnd of $G_{3}$ & 02 & 023 & 059 & $1 / 15 / 2009$ & 10A-D-43B & East & Yes \\
\hline & & & 0.59 & $1 / 15 / 2009$ & 10A-D-43C & South & Yes \\
\hline & & & & & 10A-D-45A & North & No \\
\hline
\end{tabular}


Table 4.6. Results of PCT Leaching Procedure (ASTM C1285, 7-days at $90^{\circ} \mathrm{C}$, Stainless Steel Vessel; $\mathrm{S} / \mathrm{V}=2000 \mathrm{~m}^{-1}$ ) for Crucible Glass and Corresponding Melter Glass Samples from DM10 ORP LAW Tests.

\begin{tabular}{|c|c|c|c|c|c|c|c|c|}
\hline \multicolumn{2}{|l|}{ Region } & \multicolumn{2}{|c|}{ A } & \multicolumn{3}{|c|}{$\mathrm{D}$} & \multirow{4}{*}{$\begin{array}{l}\text { ANL- } \\
\text { LRM-2 }\end{array}$} & \multirow{4}{*}{$\begin{array}{c}\text { WTP } \\
\text { Contract } \\
\text { Limit }\end{array}$} \\
\hline \multicolumn{2}{|c|}{$\begin{array}{c}\text { Tank Waste/Sub-Envelope } \\
\text { Identification }\end{array}$} & \multicolumn{2}{|c|}{ AN-105/Sub-Envelope A1 } & \multicolumn{3}{|c|}{ AN-102/Sub-Envelope C2 } & & \\
\hline \multicolumn{2}{|l|}{ Sample Type } & Crucible Glass & Melter Glass & $\begin{array}{l}\text { Crucible } \\
\text { Glass }\end{array}$ & \multicolumn{2}{|c|}{ Melter Glasses } & & \\
\hline \multicolumn{2}{|l|}{ Sample I.D. } & ORPLA20 & Y10-G-146C & ORPLD6 & $\begin{array}{l}\text { Z10-G- } \\
60 \mathrm{C}\end{array}$ & $\begin{array}{l}\text { 10A-G- } \\
53 \mathrm{C}\end{array}$ & & \\
\hline $\begin{array}{c}\text { 7-Day PCT } \\
\text { Concentration in } \\
\mathrm{mg} / \mathrm{L}\end{array}$ & $\mathrm{Si}$ & 91.43 & 90.87 & 63.40 & 76.13 & 59.73 & 81.61 & \\
\hline \multirow{4}{*}{$\begin{array}{c}\text { 7-Day PCT } \\
\text { Normalized } \\
\text { Concentrations, g/L }\end{array}$} & $\mathrm{B}$ & 1.45 & 1.30 & 1.13 & 1.25 & 0.98 & 1.17 & \\
\hline & $\mathrm{Na}$ & 1.47 & 1.32 & 1.35 & 1.58 & 1.13 & 1.12 & \\
\hline & $\mathrm{Si}$ & 0.46 & 0.45 & 0.36 & 0.44 & 0.35 & 0.32 & \\
\hline & $\mathrm{pH}$ & 11.77 & 11.58 & 11.67 & 11.65 & 11.45 & 11.08 & \\
\hline \multirow{3}{*}{$\begin{array}{l}\text { 7-Day PCT } \\
\text { Jormalized Loss } \\
\text { Rate, g/d/m² }\end{array}$} & $\mathrm{B}$ & 0.10 & 0.09 & 0.08 & 0.09 & 0.07 & 0.08 & \\
\hline & $\mathrm{Na}$ & 0.10 & 0.09 & 0.10 & 0.11 & 0.08 & 0.08 & \\
\hline & $\mathrm{Si}$ & 0.03 & 0.03 & 0.03 & 0.03 & 0.02 & 0.02 & \\
\hline
\end{tabular}




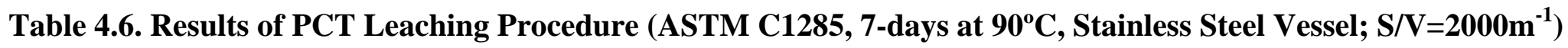
for Crucible Glass and Corresponding Melter Glass Samples from DM10 ORP LAW Tests (continued).

\begin{tabular}{|c|c|c|c|c|c|c|c|c|}
\hline \multicolumn{2}{|l|}{ Region } & \multicolumn{3}{|c|}{$\mathrm{F}$} & \multicolumn{2}{|c|}{$\mathrm{G}$} & \multirow{4}{*}{$\begin{array}{l}\text { ANL-LRM- } \\
2\end{array}$} & \multirow{4}{*}{$\begin{array}{l}\text { WTP } \\
\text { Contract } \\
\text { Limit }\end{array}$} \\
\hline \multicolumn{2}{|c|}{$\begin{array}{c}\text { Tank Waste/Sub-Envelope } \\
\text { Identification }\end{array}$} & \multicolumn{3}{|c|}{ AZ-102/Sub-Envelope B2 } & \multicolumn{2}{|c|}{ AP-101/Sub-Envelope A2 } & & \\
\hline \multicolumn{2}{|l|}{ Sample Type } & $\begin{array}{c}\text { Crucible } \\
\text { Glass }\end{array}$ & \multicolumn{2}{|c|}{ Melter Glass } & Crucible Glass & Melter Glass & & \\
\hline \multicolumn{2}{|l|}{ Sample I.D. } & ORPLF7 & $\begin{array}{l}\text { Z10-G- } \\
122 B\end{array}$ & $\begin{array}{c}\text { Z10- } \\
\text { G- } \\
153 B\end{array}$ & ORPLG9 & 10A-G-43B & & \\
\hline \multirow{4}{*}{$\begin{array}{c}\text { 7-Day PCT } \\
\text { Concentration in } \\
\text { mg/L }\end{array}$} & $\mathrm{B}$ & 9.78 & 12.13 & 12.86 & 27.42 & 34.33 & 29.08 & \\
\hline & $\mathrm{Li}$ & 12.75 & 13.27 & 13.64 & $\mathrm{NC}$ & $\mathrm{NC}$ & $\mathrm{NC}$ & \\
\hline & $\mathrm{Na}$ & 63.48 & 51.74 & 58.12 & 172.50 & 248.30 & 165.70 & \\
\hline & $\mathrm{Si}$ & 32.28 & 46.16 & 41.56 & 63.57 & 82.28 & 81.61 & \\
\hline \multirow{5}{*}{$\begin{array}{c}\text { 7-Day PCT } \\
\text { Normalized } \\
\text { Concentrations, g/L }\end{array}$} & $\mathrm{B}$ & 0.33 & 0.41 & 0.43 & 1.02 & 1.30 & 1.17 & \\
\hline & $\mathrm{Li}$ & 0.63 & 0.65 & 0.67 & $\mathrm{NC}$ & $\mathrm{NC}$ & $\mathrm{NC}$ & \\
\hline & $\mathrm{Na}$ & 0.71 & 0.59 & 0.63 & 1.18 & 1.56 & 1.12 & \\
\hline & $\mathrm{Si}$ & 0.16 & 0.23 & 0.21 & 0.32 & 0.44 & 0.32 & \\
\hline & $\mathrm{pH}$ & 11.09 & 11.12 & 11.11 & 11.60 & 11.78 & 11.08 & \\
\hline \multirow{4}{*}{$\begin{array}{l}\text { 7-Day PCT } \\
\text { Normalized Mass } \\
\text { Loss }\left(\mathrm{g} / \mathrm{m}^{2}\right)\end{array}$} & B & 0.17 & 0.20 & 0.22 & 0.51 & 0.65 & 0.59 & $<2.0$ \\
\hline & $\mathrm{Li}$ & 0.32 & 0.32 & 0.34 & $\mathrm{NC}$ & $\mathrm{NC}$ & $\mathrm{NC}$ & $<2.0$ \\
\hline & $\mathrm{Na}$ & 0.36 & 0.30 & 0.31 & 0.59 & 0.78 & 0.56 & $<2.0$ \\
\hline & $\mathrm{Si}$ & 0.08 & 0.12 & 0.11 & 0.16 & 0.22 & 0.16 & $<2.0$ \\
\hline \multirow{4}{*}{$\begin{array}{c}\text { 7-Day PCT } \\
\text { Normalized Loss } \\
\text { Rate, g/d/m² }\end{array}$} & B & 0.02 & 0.03 & 0.03 & 0.07 & 0.09 & 0.08 & \\
\hline & $\mathrm{Li}$ & 0.05 & 0.05 & 0.05 & $\mathrm{NC}$ & $\mathrm{NC}$ & $\mathrm{NC}$ & \\
\hline & $\mathrm{Na}$ & 0.05 & 0.04 & 0.04 & 0.08 & 0.11 & 0.08 & \\
\hline & $\mathrm{Si}$ & 0.01 & 0.02 & 0.02 & 0.02 & 0.03 & 0.02 & \\
\hline
\end{tabular}

NC - Not calculated 
Table 4.7. VHT Results (24 Day) for Crucible Glass and Corresponding Melter Glass Samples that Contain the Maximum Sulfur Concentration Without Formation of Secondary Phases During DM10 ORP LAW Tests.

\begin{tabular}{|c|c|c|c|c|c|c|c|c|c|c|}
\hline \multicolumn{2}{|c|}{ Region } & \multicolumn{2}{|c|}{ A } & \multicolumn{2}{|c|}{ D } & \multicolumn{3}{|c|}{$\mathbf{F}$} & \multicolumn{2}{|c|}{$\mathbf{G}$} \\
\hline \multicolumn{2}{|c|}{$\begin{array}{c}\text { Tank Waste/Sub-Envelope } \\
\text { Identification }\end{array}$} & \multicolumn{2}{|c|}{$\begin{array}{c}\text { AN-105/ } \\
\text { Sub-Envelope A1 }\end{array}$} & \multicolumn{2}{|c|}{$\begin{array}{c}\text { AN-102/ } \\
\text { Sub-Envelope C2 }\end{array}$} & \multicolumn{3}{|c|}{$\begin{array}{c}\text { AZ-102/ } \\
\text { Sub-Envelope B2 }\end{array}$} & \multicolumn{2}{|c|}{$\begin{array}{c}\text { AP101/ } \\
\text { Sub-Envelope A2 }\end{array}$} \\
\hline \multicolumn{2}{|c|}{ Sample Type } & $\begin{array}{c}\text { Crucible } \\
\text { Glass }\end{array}$ & Melter Glass & $\begin{array}{c}\text { Crucible } \\
\text { Glass }\end{array}$ & Melter Glass & $\begin{array}{c}\text { Crucible } \\
\text { Glass }\end{array}$ & \multicolumn{2}{|c|}{ Melter Glass } & $\begin{array}{c}\text { Crucible } \\
\text { Glass }\end{array}$ & Melter Glass \\
\hline \multicolumn{2}{|c|}{ Sample I.D. } & ORPLA20 & $\begin{array}{l}\text { Y10-G- } \\
146 C\end{array}$ & ORPLD6 & $10 A-G-53 C$ & ORPLF7 & $\begin{array}{l}\text { Z10-G- } \\
\text { 122B }\end{array}$ & $\begin{array}{c}\text { Z10-G- } \\
153 B\end{array}$ & ORPLG9 & $\begin{array}{c}\text { 10A-G- } \\
43 \mathrm{~B}\end{array}$ \\
\hline \multirow{3}{*}{$\begin{array}{c}\text { Based on } \\
\text { Layer } \\
\text { Thickness }\end{array}$} & $\begin{array}{l}\text { Alteration } \\
\text { depth }(\mu \mathrm{m})\end{array}$ & 75 & 190 & 200 & 300 & 150 to 300 & 300 & 250 & 450 & \multirow{6}{*}{$\begin{array}{l}\text { Coupon } \\
\text { fully } \\
\text { reacted }\end{array}$} \\
\hline & Rate $\left(\mathrm{g} / \mathrm{m}^{2} / \mathrm{d}\right)$ & 8 & 21 & 22 & 33 & 17 to 33 & 33 & 28 & 50 & \\
\hline & $\begin{array}{c}\text { Compared to } \\
\text { limit of } 50 \\
\text { g/m } / \mathbf{m}^{2} / \mathbf{d} \\
\end{array}$ & $16 \%$ & $42 \%$ & $44 \%$ & $66 \%$ & 34 to $66 \%$ & $66 \%$ & $56 \%$ & $100 \%$ & \\
\hline \multirow{3}{*}{$\begin{array}{c}\text { Based on } \\
\text { Remaining } \\
\text { Glass }\end{array}$} & $\begin{array}{l}\text { Alteration } \\
\text { depth }(\mu \mathrm{m})\end{array}$ & 65 & 140 & 164 & 246 & 164 & 209 & 234 & 370 & \\
\hline & Rate $\left(\mathrm{g} / \mathrm{m}^{2} / \mathrm{d}\right)$ & 7 & 15 & 18 & 27 & 18 & 23 & 26 & 41 & \\
\hline & $\begin{array}{c}\text { Compared to } \\
\text { limit of } 50 \\
\text { g/m } / \mathbf{m}^{2} / \mathbf{d}\end{array}$ & $14 \%$ & $30 \%$ & $36 \%$ & $54 \%$ & $36 \%$ & $46 \%$ & $52 \%$ & $82 \%$ & \\
\hline
\end{tabular}

Rates calculated with an average density of $2.65 \mathrm{~g} / \mathrm{cm}^{3}$

NC - Not calculated 
Table 5.1. Maximum Sodium and Sulfur Oxide Concentrations Achieved in Crucible and Melter Tests (wt\% in Glass).

\begin{tabular}{|c|c|c|c|c|c|c|c|c|}
\hline \multicolumn{2}{|c|}{ Region } & & \multicolumn{2}{|c|}{ A } & \multicolumn{2}{|c|}{ D } & $\mathrm{F}$ & $\mathrm{G}$ \\
\hline \multicolumn{2}{|c|}{ Tank Waste/ } & $\begin{array}{l}\text { Sub-Envelope } \\
\text { Identification }\end{array}$ & \multicolumn{2}{|c|}{$\begin{array}{c}\text { AN-105/ } \\
\text { Sub- } \\
\text { Envelope A1 }\end{array}$} & \multicolumn{2}{|c|}{$\begin{array}{c}\mathrm{AN}-102 / \\
\text { Sub-Envelope } \\
\text { C2 }\end{array}$} & $\begin{array}{c}\text { AZ-102/ } \\
\text { Sub-Envelope } \\
\text { B2 }\end{array}$ & $\begin{array}{c}\text { AP-101 } \\
\text { Sub-Envelope } \\
\text { A2 }\end{array}$ \\
\hline \multirow{4}{*}{$\begin{array}{l}\text { Crucible } \\
\text { Studies }\end{array}$} & & $\mathrm{Na}_{2} \mathrm{O}$ & \multicolumn{2}{|c|}{24.0} & \multicolumn{2}{|c|}{22.0} & 12.0 & 21.0 \\
\hline & & $\mathrm{K}_{2} \mathrm{O}$ & \multicolumn{2}{|c|}{0.5} & \multicolumn{2}{|c|}{0.2} & 0.5 & 5.76 \\
\hline & & $\mathrm{O}_{3}$ (batching) & \multicolumn{2}{|c|}{0.37} & \multicolumn{2}{|c|}{0.89} & 1.44 & 0.48 \\
\hline & & $\mathrm{O}_{3}$ (bubbling) & \multicolumn{2}{|c|}{ NM } & \multicolumn{2}{|c|}{ NM } & NM & 0.55 \\
\hline \multirow{4}{*}{$\begin{array}{l}\text { Melter } \\
\text { Studies }\end{array}$} & & rget Feed $\mathrm{Na}_{2} \mathrm{O}$ & \multicolumn{2}{|c|}{24.0} & \multicolumn{2}{|c|}{22.0} & 12.0 & 21.0 \\
\hline & & arget Feed $\mathrm{SO}_{3}$ & \multicolumn{2}{|c|}{0.7} & \multicolumn{2}{|c|}{1.2} & 1.5 & $<0.2$ \\
\hline & & leasured $\mathrm{Na}_{2} \mathrm{O}$ & \multicolumn{2}{|c|}{23.0} & \multicolumn{2}{|c|}{23.2} & 12.5 & 21.5 \\
\hline & & Measured $\mathrm{SO}_{3}$ & \multicolumn{2}{|c|}{0.63} & \multicolumn{2}{|c|}{1.26} & 1.35 & 0.21 \\
\hline \multirow{4}{*}{$\begin{array}{l}\text { Previous } \\
\text { Melter } \\
\text { Studies }\end{array}$} & & rget Feed $\mathrm{Na}_{2} \mathrm{O}$ & $\begin{array}{c}23.0 \\
{[6]}\end{array}$ & $\begin{array}{c}24.0 \\
{[7]} \\
\end{array}$ & $\begin{array}{c}20.0 \\
{[5]}\end{array}$ & $\begin{array}{c}21.0 \\
{[7]}\end{array}$ & $\begin{array}{r}10.0 \\
{[6]} \\
\end{array}$ & \\
\hline & & arget Feed $\mathrm{SO}_{3}$ & 1.0 & 0.6 & 1.125 & 1.1 & 1.5 & \\
\hline & & leasured $\mathrm{Na}_{2} \mathrm{O}$ & 22.0 & 23.8 & 19.9 & 18.1 & 10.7 & \\
\hline & & Measured $\mathrm{SO}_{3}$ & 0.88 & 0.52 & 1.07 & 0.89 & 1.33 & \\
\hline
\end{tabular}


Table 5.2 Waste Loading Improvements in LAW Glass Formulations Developed for WTP and ORP.

\begin{tabular}{|c|c|c|c|c|c|c|c|c|c|c|c|c|c|c|c|}
\hline $\begin{array}{l}\text { Waste } \\
\text { ID }\end{array}$ & \multicolumn{3}{|c|}{ Bechtel Baseline Loadings } & \multicolumn{3}{|c|}{ Bechtel Correlation (2007) } & \multicolumn{3}{|c|}{ ORP (2006) Loadings } & \multicolumn{3}{|c|}{ ORP (2007) Loadings } & \multicolumn{3}{|c|}{ ORP (2008) Loadings } \\
\hline \multirow{4}{*}{$\begin{array}{l}\text { AN- } \\
105\end{array}$} & \multirow{4}{*}{$\begin{array}{c}\text { Glass } \\
\text { LAWA44 }\end{array}$} & $26.0 \%$ & Waste & \multirow{4}{*}{$\begin{array}{c}\text { Glass } \\
\text { LAWE4H }\end{array}$} & $27.2 \%$ & Waste & \multirow{4}{*}{$\begin{array}{l}\text { Glass } \\
\text { LAWA187 }\end{array}$} & $30.5 \%$ & Waste & \multirow{4}{*}{$\begin{array}{c}\text { Glass } \\
\text { ORPLA15 }\end{array}$} & $31.6 \%$ & Waste & \multirow{4}{*}{$\begin{array}{c}\text { Glass } \\
\text { ORPLA20 }\end{array}$} & $31.6 \%$ & Waste \\
\hline & & $20.0 \%$ & $\mathrm{Na}_{2} \mathrm{O}$ & & $21.3 \%$ & $\mathrm{Na}_{2} \mathrm{O}$ & & $22.9 \%$ & $\mathrm{Na}_{2} \mathrm{O}$ & & $24.0 \%$ & $\mathrm{Na}_{2} \mathrm{O}$ & & $24.0 \%$ & $\mathrm{Na}_{2} \mathrm{O}$ \\
\hline & & $0.5 \%$ & $\mathrm{~K}_{2} \mathrm{O}$ & & $0.5 \%$ & $\mathrm{~K}_{2} \mathrm{O}$ & & $0.5 \%$ & $\mathrm{~K}_{2} \mathrm{O}$ & & $0.5 \%$ & $\mathrm{~K}_{2} \mathrm{O}$ & & $0.5 \%$ & $\mathrm{~K}_{2} \mathrm{O}$ \\
\hline & & $0.2 \%$ & $\mathrm{SO}_{3}$ & & $0.4 \%$ & $\mathrm{SO}_{3}$ & & $1.0 \%$ & $\mathrm{SO}_{3}$ & & $0.6 \%$ & $\mathrm{SO}_{3}$ & & $0.7 \%$ & $\mathrm{SO}_{3}$ \\
\hline \multirow{4}{*}{$\begin{array}{l}\text { AP- } \\
101\end{array}$} & \multirow{4}{*}{$\begin{array}{c}\text { Glass } \\
\text { LAWA126 }\end{array}$} & $24.5 \%$ & Waste & \multirow{4}{*}{$\begin{array}{c}\text { Glass } \\
\text { LAWE3 }\end{array}$} & $25.4 \%$ & Waste & & \multirow{4}{*}{\multicolumn{3}{|c|}{ 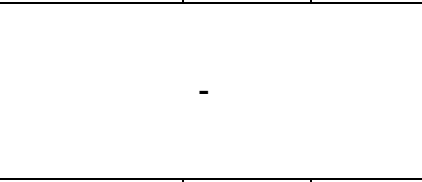 }} & \multirow{4}{*}{$\begin{array}{c}\text { Glass } \\
\text { ORPLG9 }\end{array}$} & $29.1 \%$ & Waste \\
\hline & & $18.5 \%$ & $\mathrm{Na}_{2} \mathrm{O}$ & & $18.2 \%$ & $\mathrm{Na}_{2} \mathrm{O}$ & & & & & & & & $21.0 \%$ & $\mathrm{Na}_{2} \mathrm{O}$ \\
\hline & & $3.8 \%$ & $\mathrm{~K}_{2} \mathrm{O}$ & & $5.0 \%$ & $\mathrm{~K}_{2} \mathrm{O}$ & & & & & & & & $5.8 \%$ & $\mathrm{~K}_{2} \mathrm{O}$ \\
\hline & & $0.4 \%$ & $\mathrm{SO}_{3}$ & & $0.4 \%$ & $\mathrm{SO}_{3}$ & & & & & & & & $0.2 \%$ & $\mathrm{SO}_{3}$ \\
\hline \multirow{4}{*}{$\begin{array}{l}\text { AN- } \\
107\end{array}$} & \multirow{4}{*}{$\begin{array}{l}\text { Glass } \\
\text { LAWC22 }\end{array}$} & $16.2 \%$ & Waste & \multirow{4}{*}{$\begin{array}{c}\text { Glass } \\
\text { LAWE5H }\end{array}$} & $20.6 \%$ & Waste & \multirow{4}{*}{\multicolumn{3}{|c|}{-}} & \multirow{4}{*}{$\begin{array}{c}\text { Glass } \\
\text { ORPLB4 }\end{array}$} & $26.2 \%$ & Waste & \multirow{4}{*}{\multicolumn{3}{|c|}{ - }} \\
\hline & & $14.4 \%$ & $\mathrm{Na}_{2} \mathrm{O}$ & & $19.0 \%$ & $\mathrm{Na}_{2} \mathrm{O}$ & & & & & $24.0 \%$ & $\mathrm{Na}_{2} \mathrm{O}$ & & & \\
\hline & & $0.1 \%$ & $\mathrm{~K}_{2} \mathrm{O}$ & & $0.5 \%$ & $\mathrm{~K}_{2} \mathrm{O}$ & & & & & $0.1 \%$ & $\mathrm{~K}_{2} \mathrm{O}$ & & & \\
\hline & & $0.4 \%$ & $\mathrm{SO}_{3}$ & & $0.5 \%$ & $\mathrm{SO}_{3}$ & & & & & $0.9 \%$ & $\mathrm{SO}_{3}$ & & & \\
\hline \multirow{4}{*}{$\begin{array}{l}\text { AN- } \\
104\end{array}$} & \multirow{4}{*}{$\begin{array}{c}\text { Glass } \\
\text { LAWA137 }\end{array}$} & $20.0 \%$ & Waste & \multirow{4}{*}{$\begin{array}{c}\text { Glass } \\
\text { LAWE6H }\end{array}$} & $20.9 \%$ & Waste & & & & \multirow{4}{*}{$\begin{array}{c}\text { Glass } \\
\text { ORPLC5 }\end{array}$} & $31.0 \%$ & Waste & & & \\
\hline & & $14.6 \%$ & $\mathrm{Na}_{2} \mathrm{O}$ & & $15.8 \%$ & $\mathrm{Na}_{2} \mathrm{O}$ & & - & & & $23.6 \%$ & $\mathrm{Na}_{2} \mathrm{O}$ & & & \\
\hline & & $0.3 \%$ & $\mathrm{~K}_{2} \mathrm{O}$ & & $0.5 \%$ & $\mathrm{~K}_{2} \mathrm{O}$ & & - & & & $0.5 \%$ & $\mathrm{~K}_{2} \mathrm{O}$ & & - & \\
\hline & & $0.4 \%$ & $\mathrm{SO}_{3}$ & & $0.5 \%$ & $\mathrm{SO}_{3}$ & & & & & $0.7 \%$ & $\mathrm{SO}_{3}$ & & & \\
\hline & & $14.0 \%$ & Waste & & $16.2 \%$ & Waste & & $24.1 \%$ & Waste & & $24.9 \%$ & Waste & & $25.9 \%$ & Waste \\
\hline AN- & Glass & $12.0 \%$ & $\mathrm{Na}_{2} \mathrm{O}$ & Glass & $13.5 \%$ & $\mathrm{Na}_{2} \mathrm{O}$ & Glass & $20.0 \%$ & $\mathrm{Na}_{2} \mathrm{O}$ & Glass & $21.0 \%$ & $\mathrm{Na}_{2} \mathrm{O}$ & Glass & $22.0 \%$ & $\mathrm{Na}_{2} \mathrm{O}$ \\
\hline 102 & LAWC35 & $0.1 \%$ & $\mathrm{~K}_{2} \mathrm{O}$ & LAWE7H & $0.5 \%$ & $\mathrm{~K}_{2} \mathrm{O}$ & LAWC100 & $0.2 \%$ & $\mathrm{~K}_{2} \mathrm{O}$ & ORPLD1 & $0.2 \%$ & $\mathrm{~K}_{2} \mathrm{O}$ & ORPLD6 & $0.2 \%$ & $\mathrm{~K}_{2} \mathrm{O}$ \\
\hline & & $0.6 \%$ & $\mathrm{SO}_{3}$ & & $0.6 \%$ & $\mathrm{SO}_{3}$ & & $1.1 \%$ & $\mathrm{SO}_{3}$ & & $1.1 \%$ & $\mathrm{SO}_{3}$ & & $1.2 \%$ & $\mathrm{SO}_{3}$ \\
\hline & & $7.3 \%$ & Waste & & $11.3 \%$ & Waste & & & & & $19.8 \%$ & Waste & & & \\
\hline AZ- & Glass & $5.5 \%$ & $\mathrm{Na}_{2} \mathrm{O}$ & Glass & $8.9 \%$ & $\mathrm{Na}_{2} \mathrm{O}$ & & & & Glass & $16.0 \%$ & $\mathrm{Na}_{2} \mathrm{O}$ & & & \\
\hline 101 & LAWB83 & $0.2 \%$ & $\mathrm{~K}_{2} \mathrm{O}$ & LAWE9H & $0.5 \%$ & $\mathrm{~K}_{2} \mathrm{O}$ & & - & & ORPLE12 & $0.6 \%$ & $\mathrm{~K}_{2} \mathrm{O}$ & & - & \\
\hline & & $0.7 \%$ & $\mathrm{SO}_{3}$ & & $0.7 \%$ & $\mathrm{SO}_{3}$ & & & & & $1.5 \%$ & $\mathrm{SO}_{3}$ & & & \\
\hline & & $3.7 \%$ & Waste & & $6.2 \%$ & Waste & & $11.9 \%$ & Waste & & & & & $14.3 \%$ & Waste \\
\hline AZ- & Glass & $5.5 \%$ & $\mathrm{Na}_{2} \mathrm{O}$ & Glass & $5.7 \%$ & $\mathrm{Na}_{2} \mathrm{O}$ & Glass & $10.0 \%$ & $\mathrm{Na}_{2} \mathrm{O}$ & & & & Glass & $12.0 \%$ & $\mathrm{Na}_{2} \mathrm{O}$ \\
\hline 102 & LAWB96 & $0.1 \%$ & $\mathrm{~K}_{2} \mathrm{O}$ & LAWE10H & $0.5 \%$ & $\mathrm{~K}_{2} \mathrm{O}$ & LAWB99 & $0.4 \%$ & $\mathrm{~K}_{2} \mathrm{O}$ & & - & & ORPLF7 & $0.5 \%$ & $\mathrm{~K}_{2} \mathrm{O}$ \\
\hline & & $0.7 \%$ & $\mathrm{SO}_{3}$ & & $0.8 \%$ & $\mathrm{SO}_{3}$ & & $1.5 \%$ & $\mathrm{SO}_{3}$ & & & & & $1.5 \%$ & $\mathrm{SO}_{3}$ \\
\hline
\end{tabular}

- Empty data field 


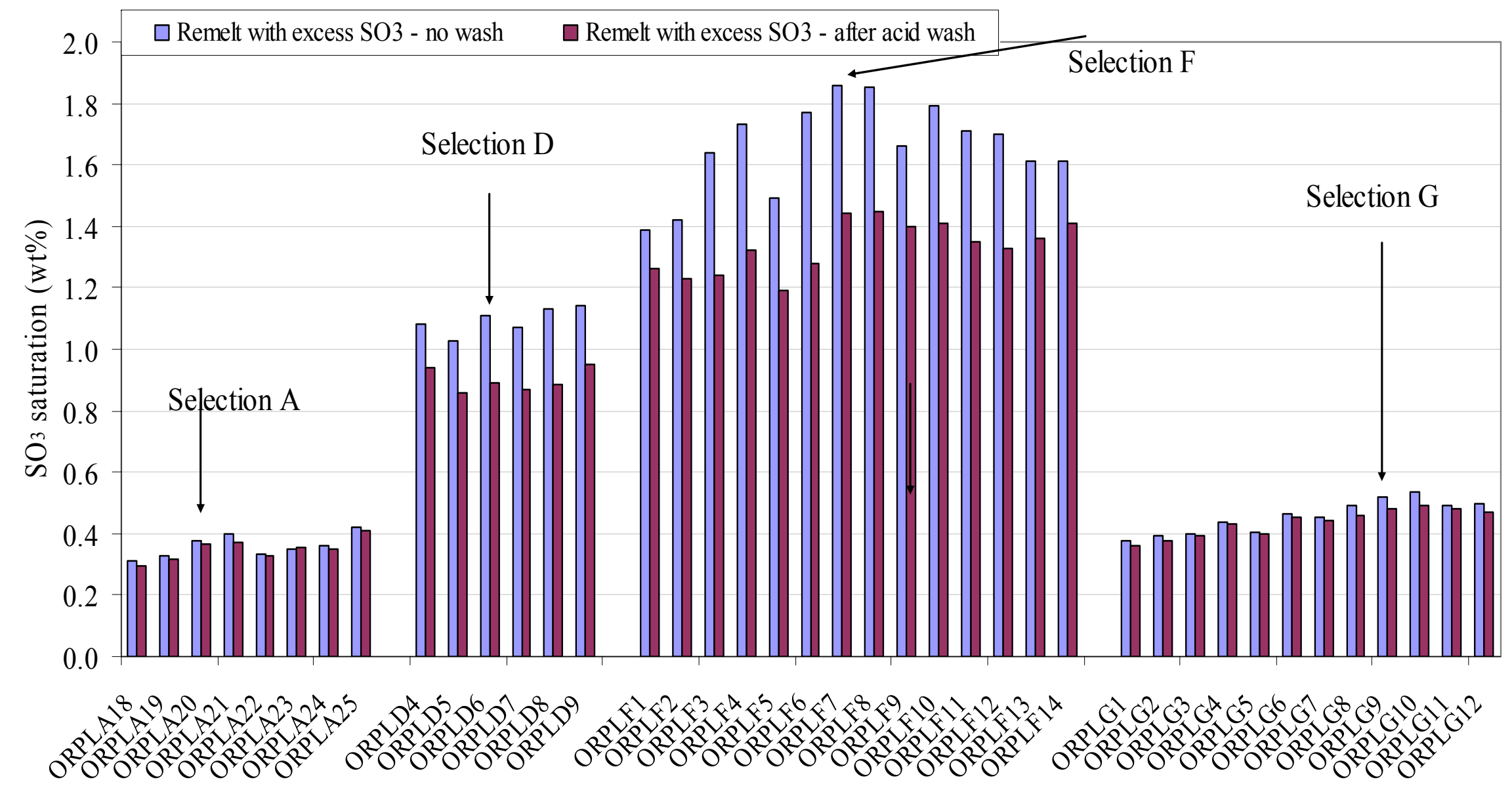

Figure 2.1. Sulfate solubility determined by remelting with excess $\mathrm{SO}_{3}$ for forty one new ORP LAW crucible glasses. 


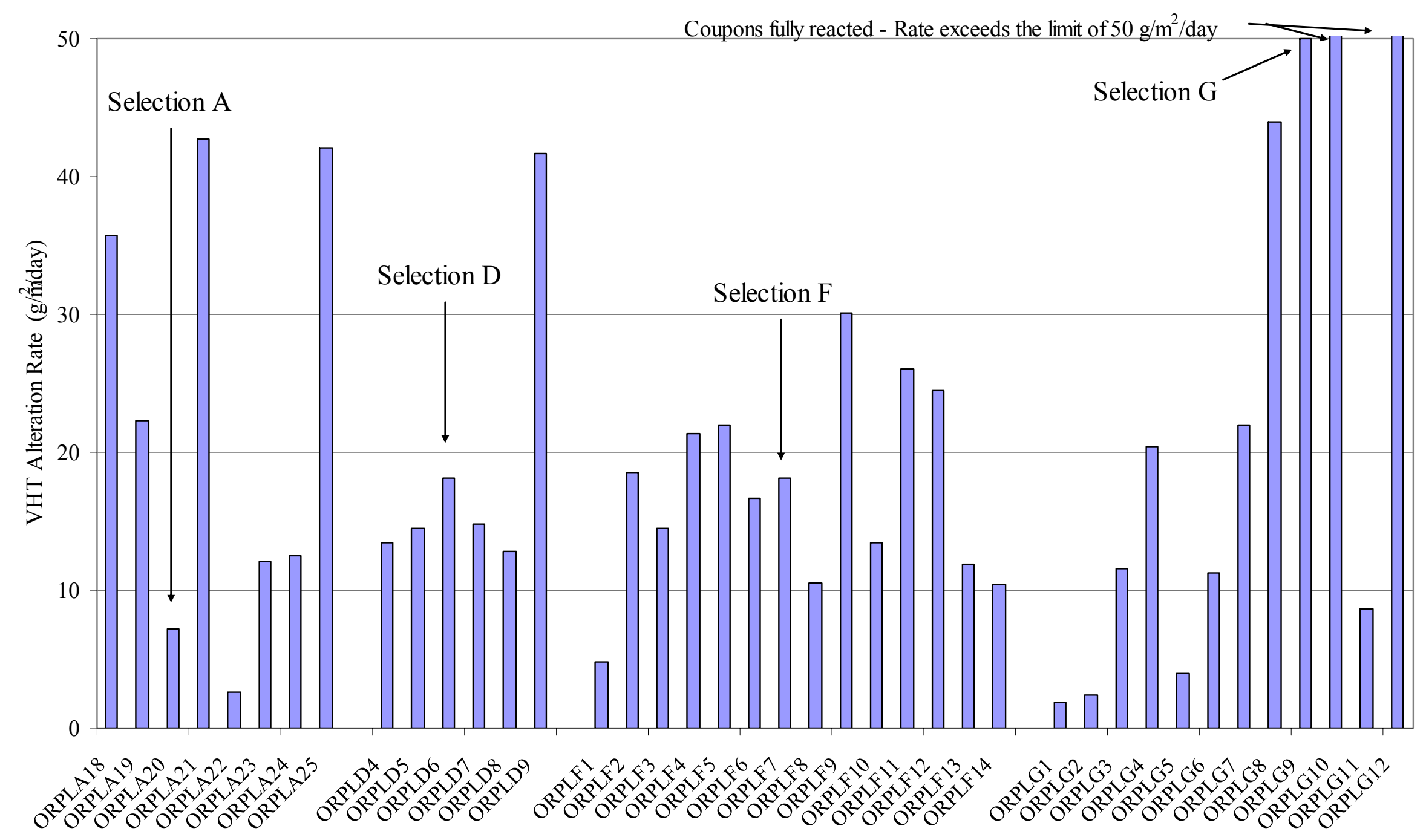

Figure 2.2. VHT results for forty one new ORP LAW crucible glasses.

(Percent relative standard deviation (\%RSD) of VHT measurement is estimated to be 31 [60]) 


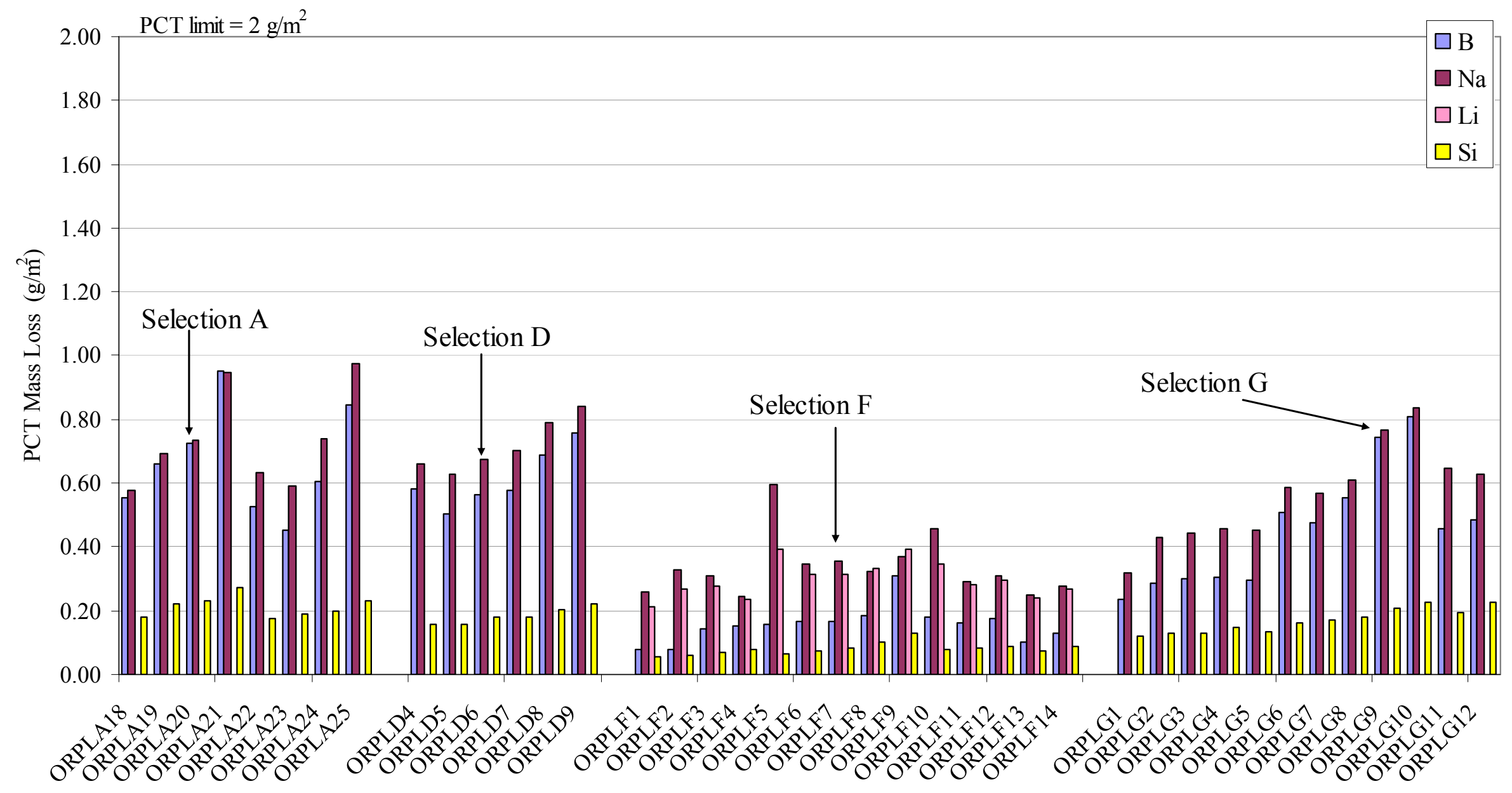

Figure 2.3. Normalized PCT releases for forty one new ORP LAW crucible glasses.

(Percent relative standard deviations (\%RSDs) of PCT measurements estimated from round robin testing are PCT-B 27, PCT-Na 21, and PCT-Si 15 [66]) 


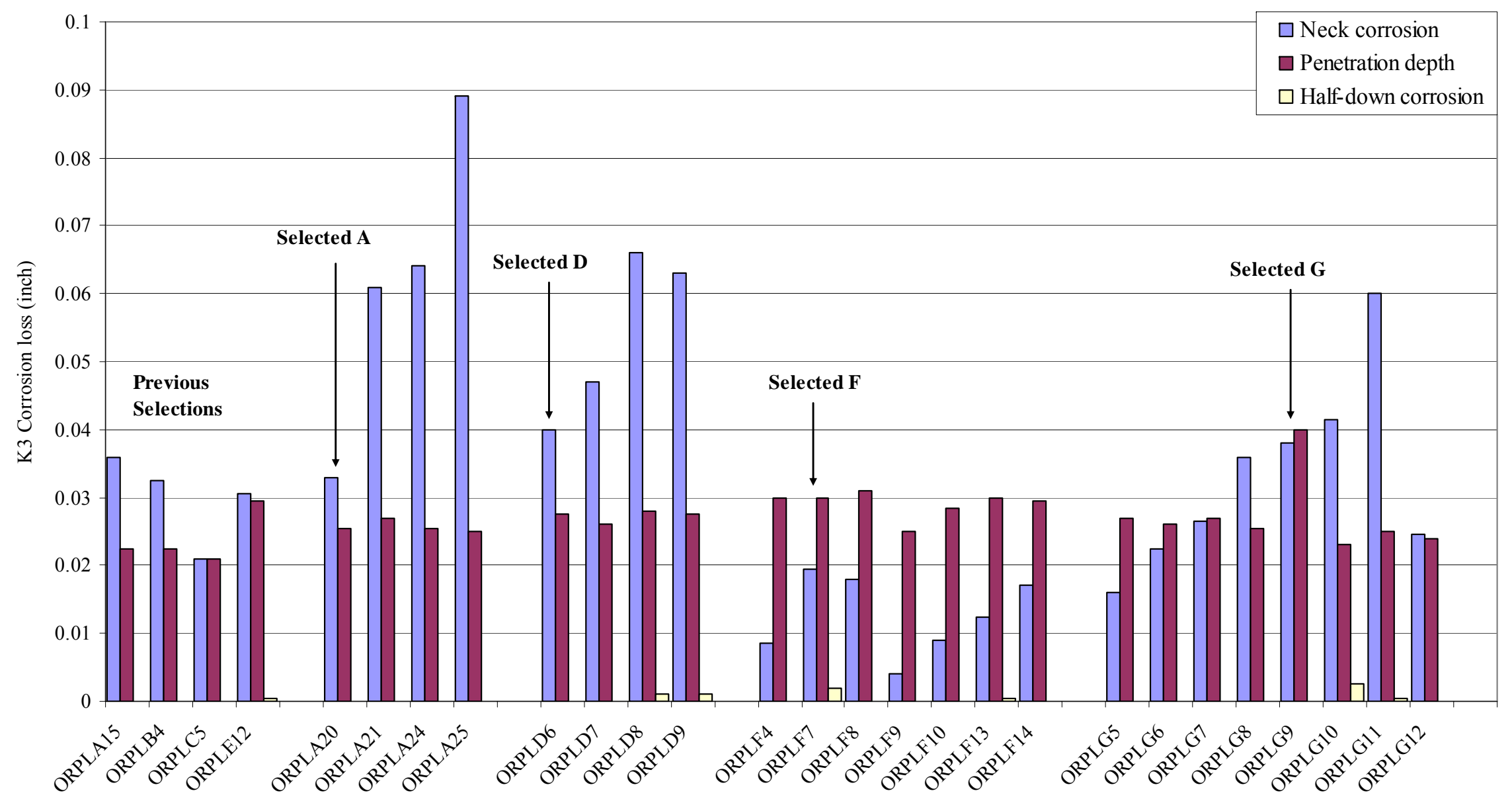

Figure 2.4. K-3 corrosion results for thirty eight new ORP LAW crucible glasses and four previous formulations. 


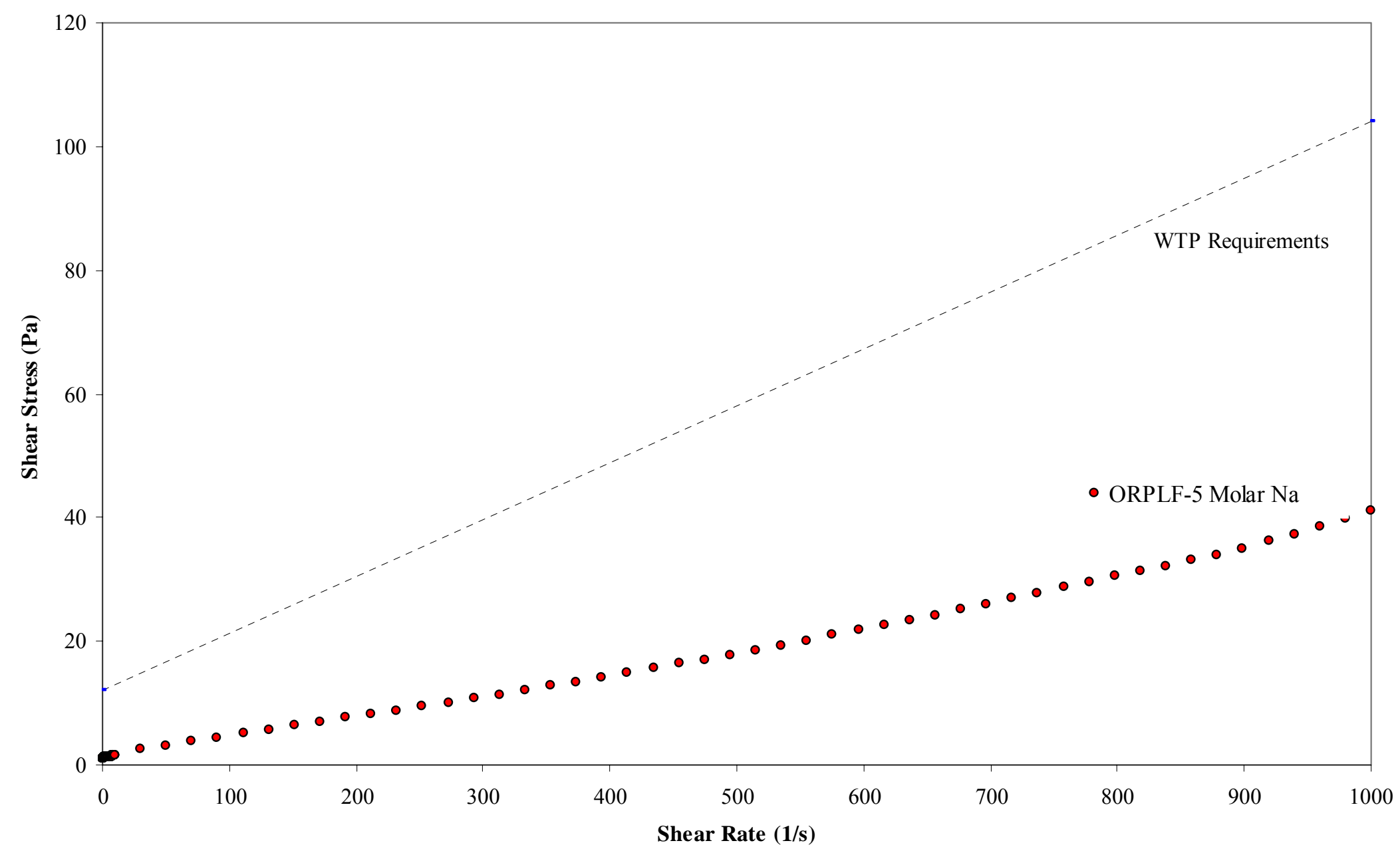

Figure 2.5 Rheology of ORLPF feed at 5 Molar sodium; WTP upper bound is also shown.

(The measurements are accurate to $\pm 10 \%$ ) 


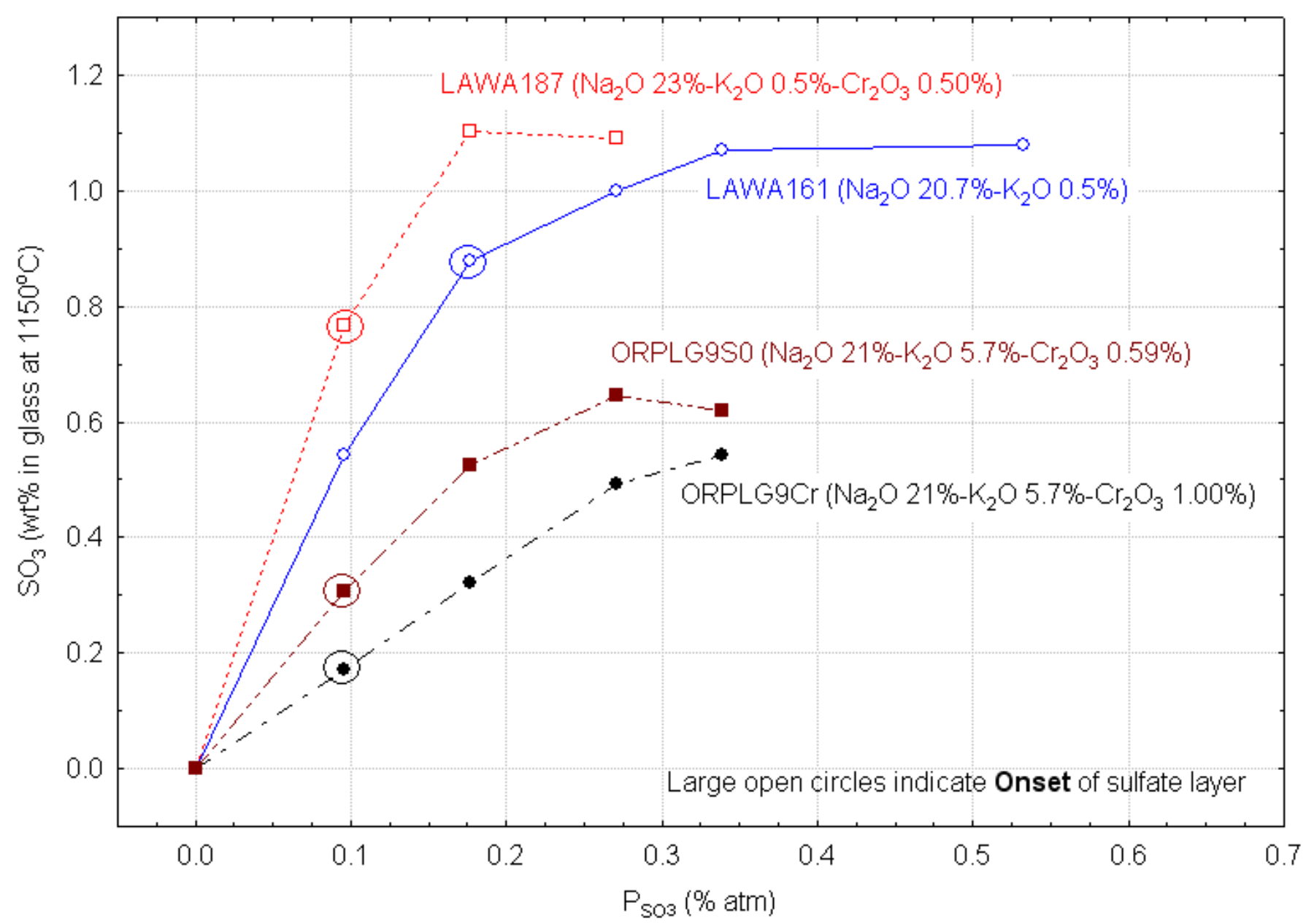

Figure 2.6. Results of $\mathrm{SO}_{2} / \mathrm{O}_{2}$ gas bubbling tests on the new ORP LAW glass ORPLG9 at the nominal $\mathrm{Cr}_{2} \mathrm{O}_{3}$ content of 0.5 wt $\%$ and at $1 \mathrm{wt} \% \mathrm{Cr}_{2} \mathrm{O}_{3}$ and the previous ORP Envelope A glasses LAWA161 and LAWA187 at $1150{ }^{\circ} \mathrm{C}$. Partial pressure of $\mathrm{SO}_{3}$ vs. the $\mathrm{SO}_{3}$ concentration in the glass melt. The horizontal portions indicate the solubility limits while the slopes at lower concentrations provide measures of the activity coefficient of $\mathrm{SO}_{3}$ in the melt and the onset of a sulfate layer.

(The wt $\% \mathrm{SO}_{3}$ in glass values are accurate to $\pm 10 \%$ and the $\mathrm{P}_{\mathrm{SO} 3}$ values are calculated from gas flow rates accurate to $\pm 5 \%$ ) 


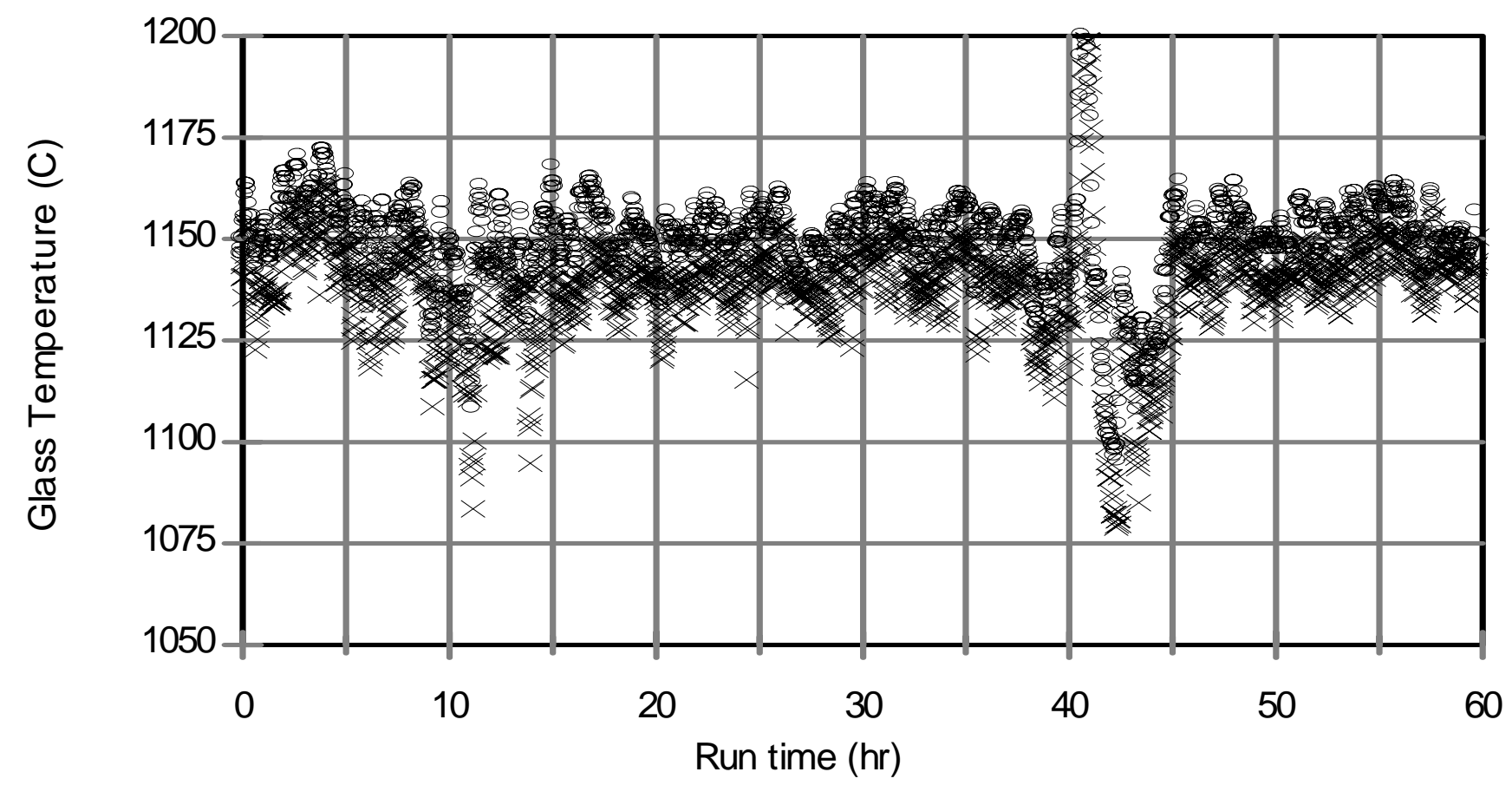

- 2" from bottom

$\times \quad 4$ " from bottom

Figure 3.1.a. Representative plot of glass pool temperatures during DM10 tests. This plot is from the first test performed (Test A). The temperatures at 2" above the floor, which are most representative of the bulk glass temperature, closely approximate the target of $1150^{\circ} \mathrm{C}$.

(Temperature measurements are accurate to $\pm 5^{\circ} \mathrm{C}$ ) 


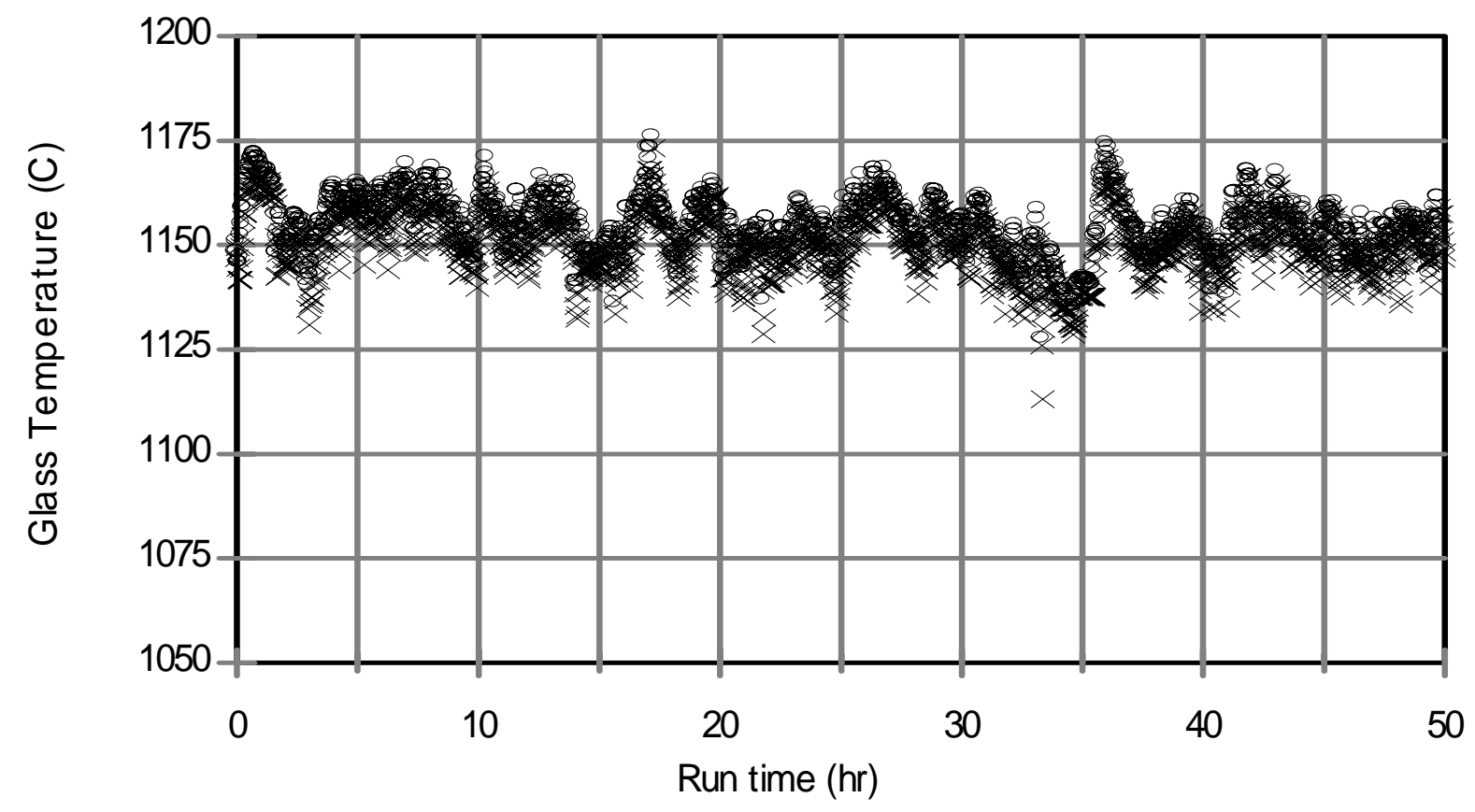

Figure 3.1.b. Representative plot of glass pool temperatures during DM10 tests. This plot is from the last full test performed (Test G). The temperatures at 2" above the floor, which are most representative of the bulk glass temperature, closely approximate the target of $1150^{\circ} \mathrm{C}$.

(Temperature measurements are accurate to $\pm 5^{\circ} \mathrm{C}$ ) 


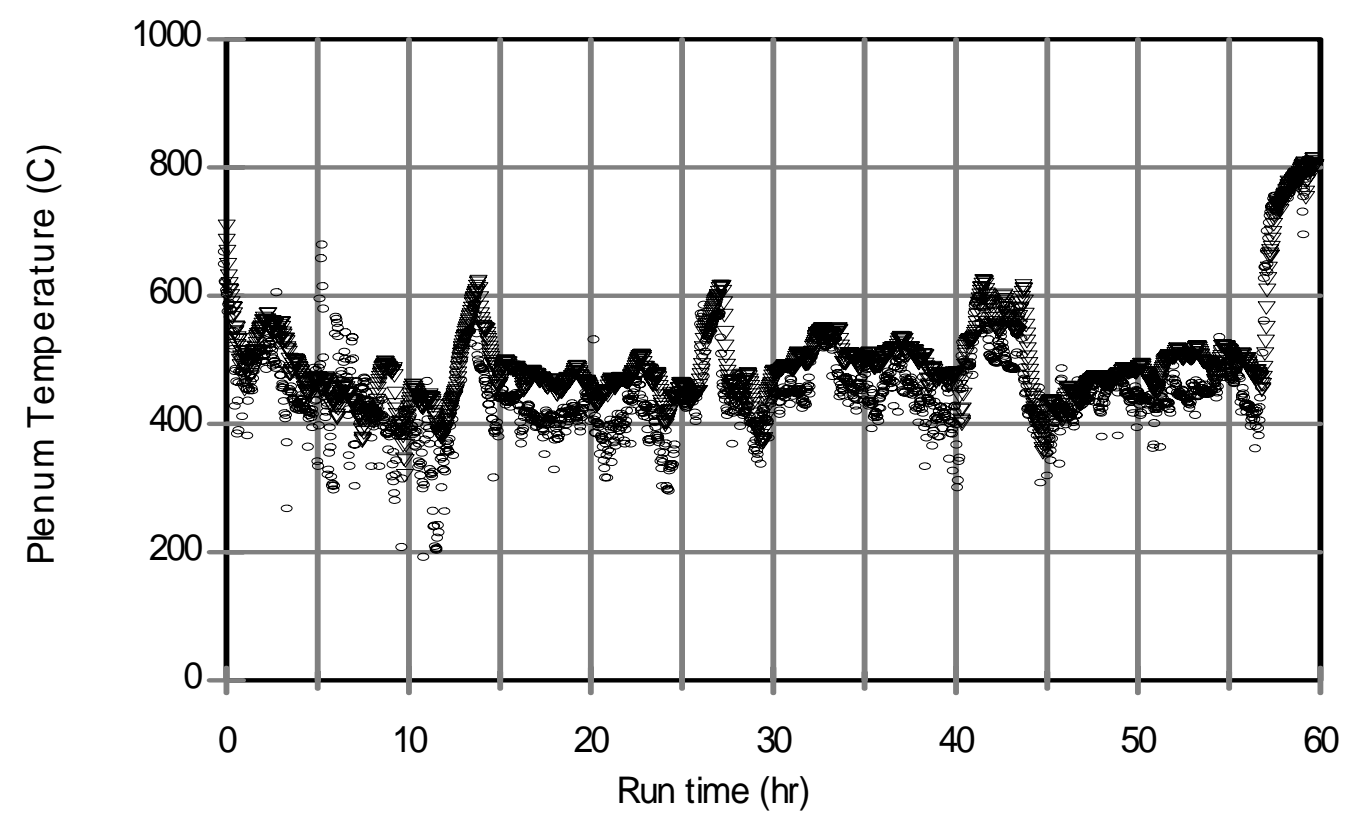
$\checkmark$ Thermowell
- Exposed

Figure 3.2.a. Representative plot of plenum temperatures during DM10 tests. This plot is from the first test performed (Test A). The temperatures fall into the 550 to $350^{\circ} \mathrm{C}$ range during steady state processing (higher temperatures occurred at the beginning of testing and during sampling periods in between test segments).

(Temperature measurements are accurate to $\pm 5^{\circ} \mathrm{C}$ ) 


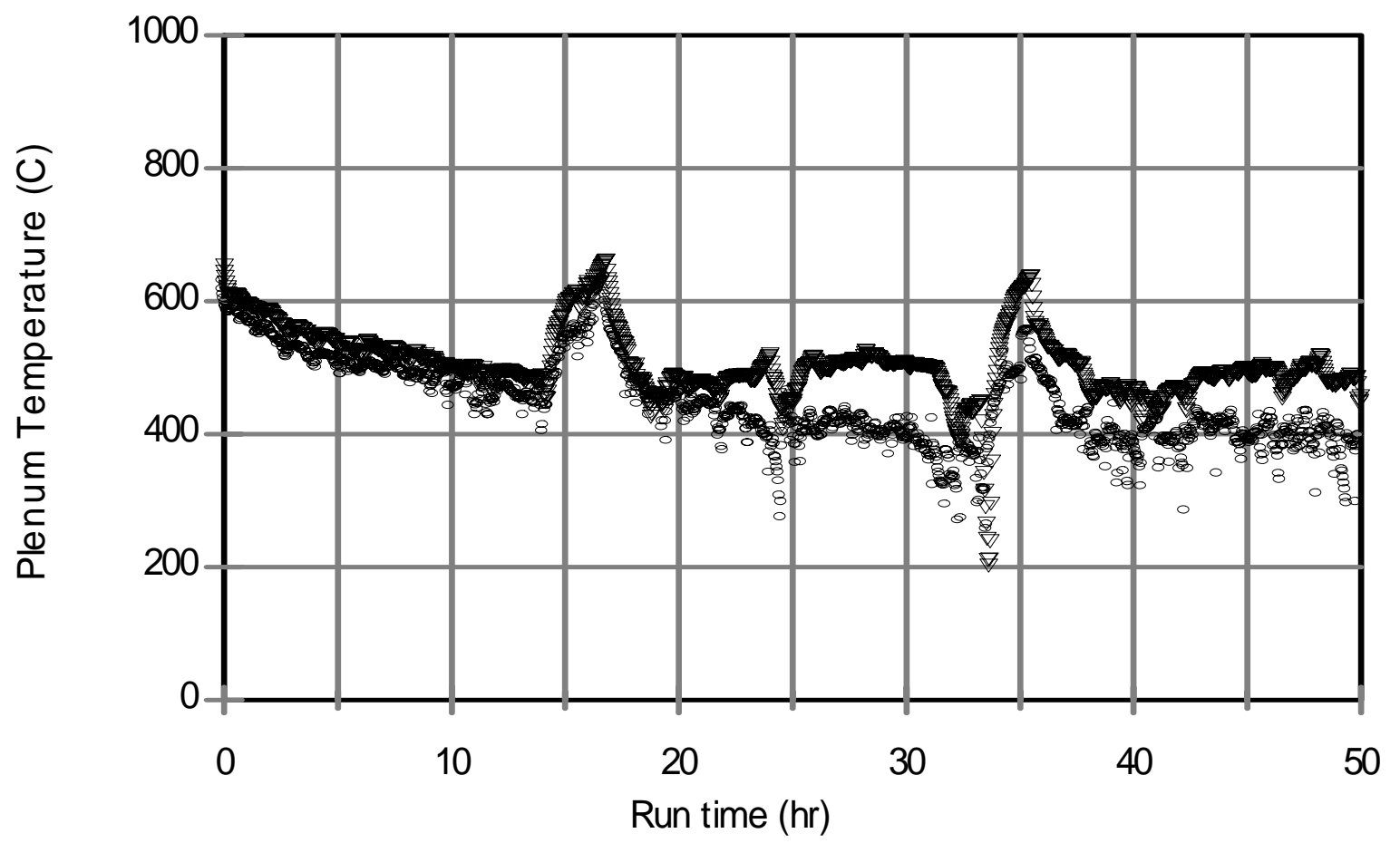

$\nabla$ Thermowell

- Exposed

Figure 3.2.b. Representative plot of plenum temperatures during DM10 tests. This plot is from the last full test performed (Test G). The temperatures fall into the 500 to $350^{\circ} \mathrm{C}$ range during steady state processing (higher temperatures occurred at the beginning of testing and during sampling periods in between test segments).

(Temperature measurements are accurate to $\pm 5^{\circ} \mathrm{C}$ ) 


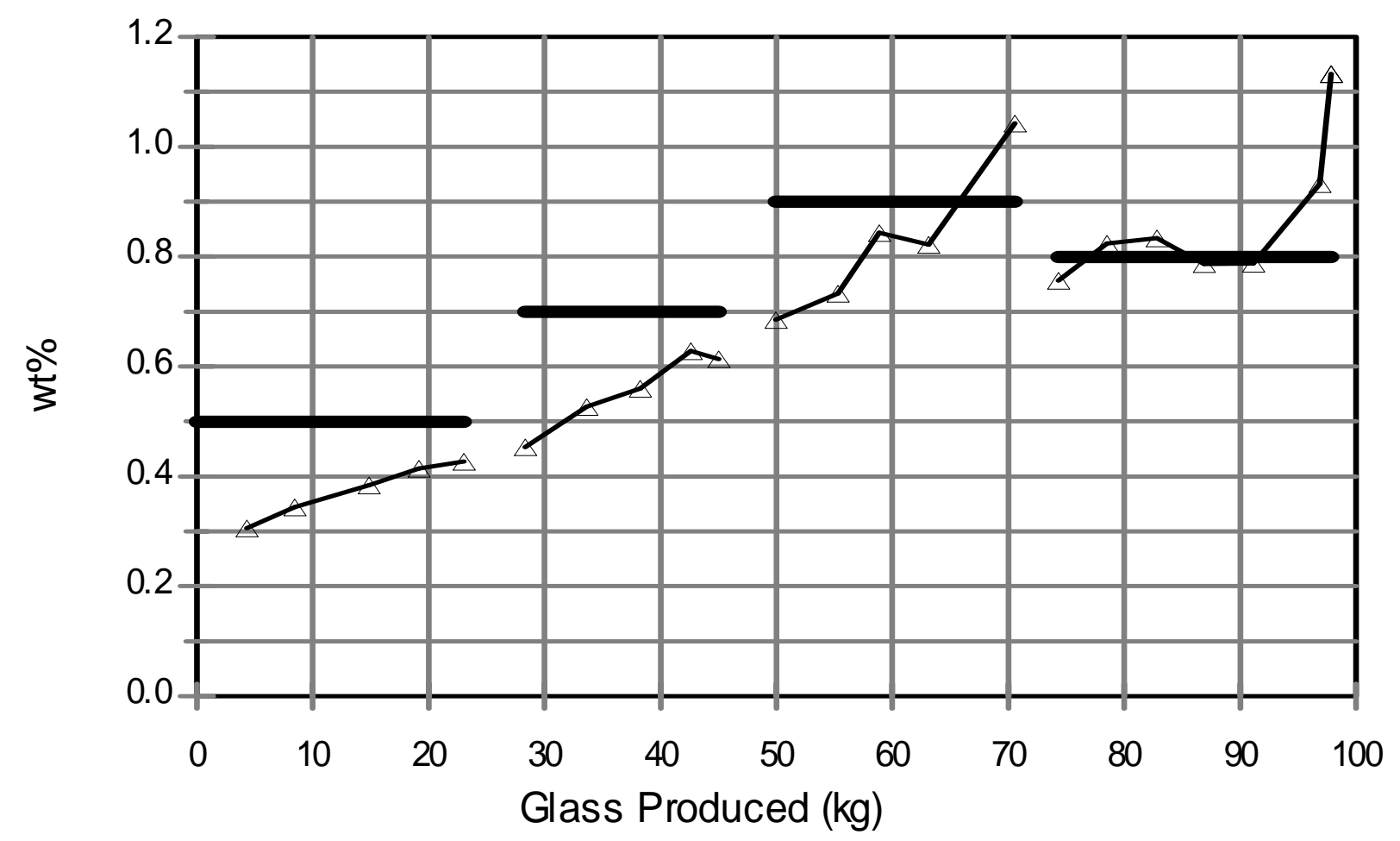

$$
\triangle \text { SO3 Measured } \quad \text { SO3 Target }
$$

Figure 3.3.a. XRF analysis of sulfur in DM10 product glasses from Test A.

(See Table 4.2 and Section 4.1 for details of composition analysis) 


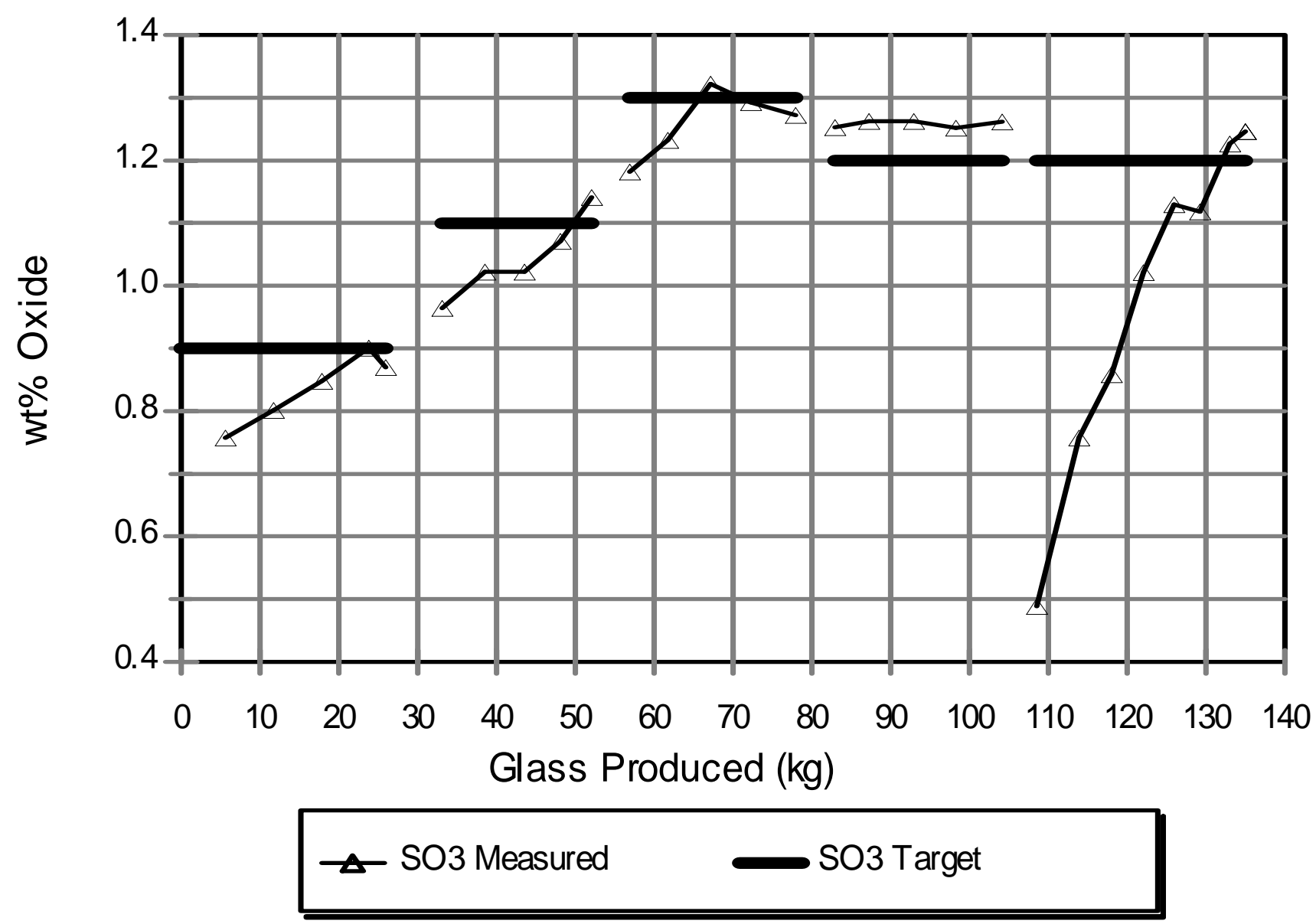

Figure 3.3.b. XRF analysis of sulfur in DM10 product glasses from Test D. Note: Other testing and therefore melt pool turnover occurred between the fourth and fifth test segments shown.

(See Table 4.2 and Section 4.1 for details of composition analysis) 


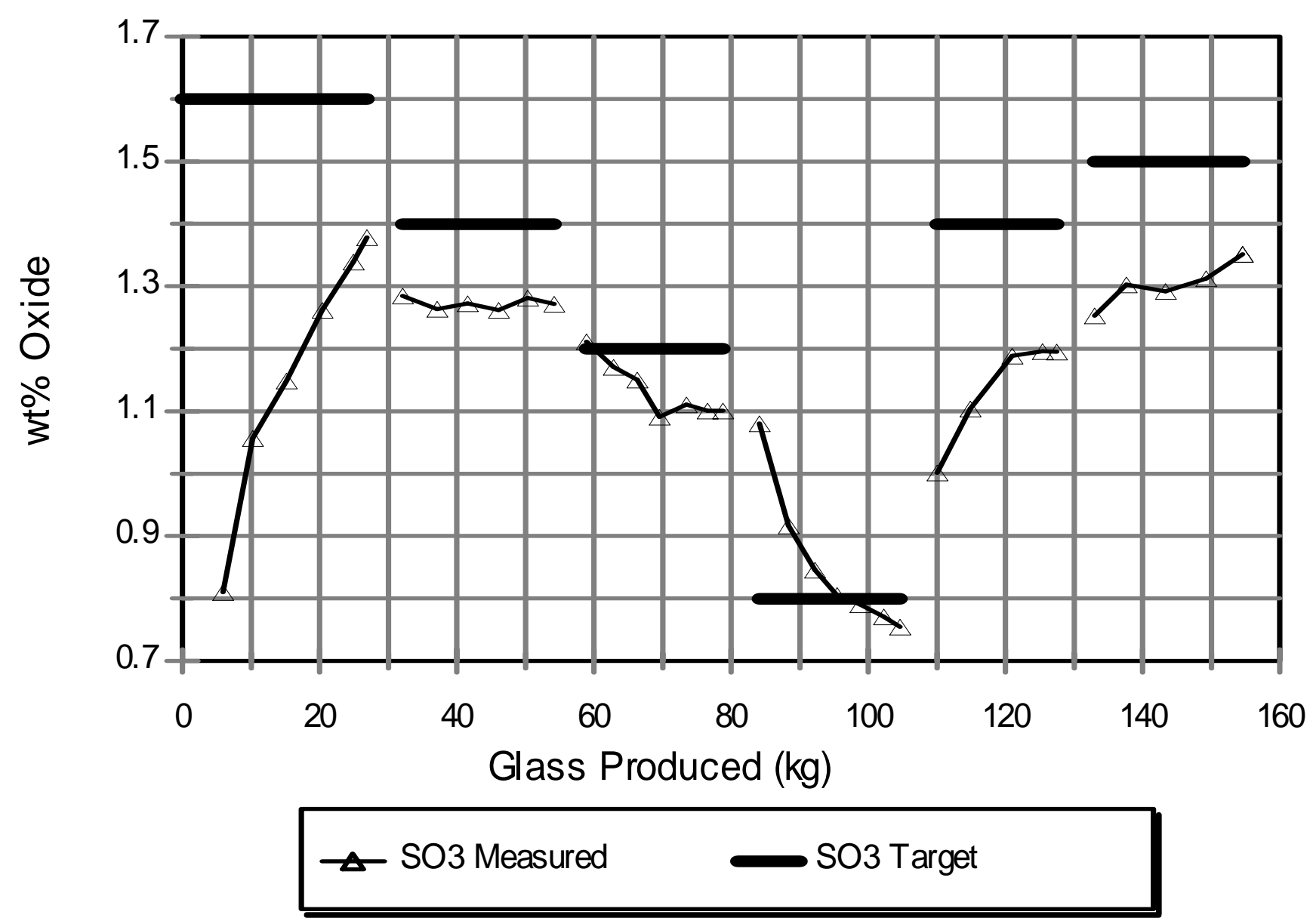

Figure 3.3.c. XRF analysis of sulfur in DM10 product glasses from Test F. Note: Other testing and therefore melt pool turnover occurred between the fourth and fifth test segments shown.

(See Table 4.2 and Section 4.1 for details of composition analysis) 


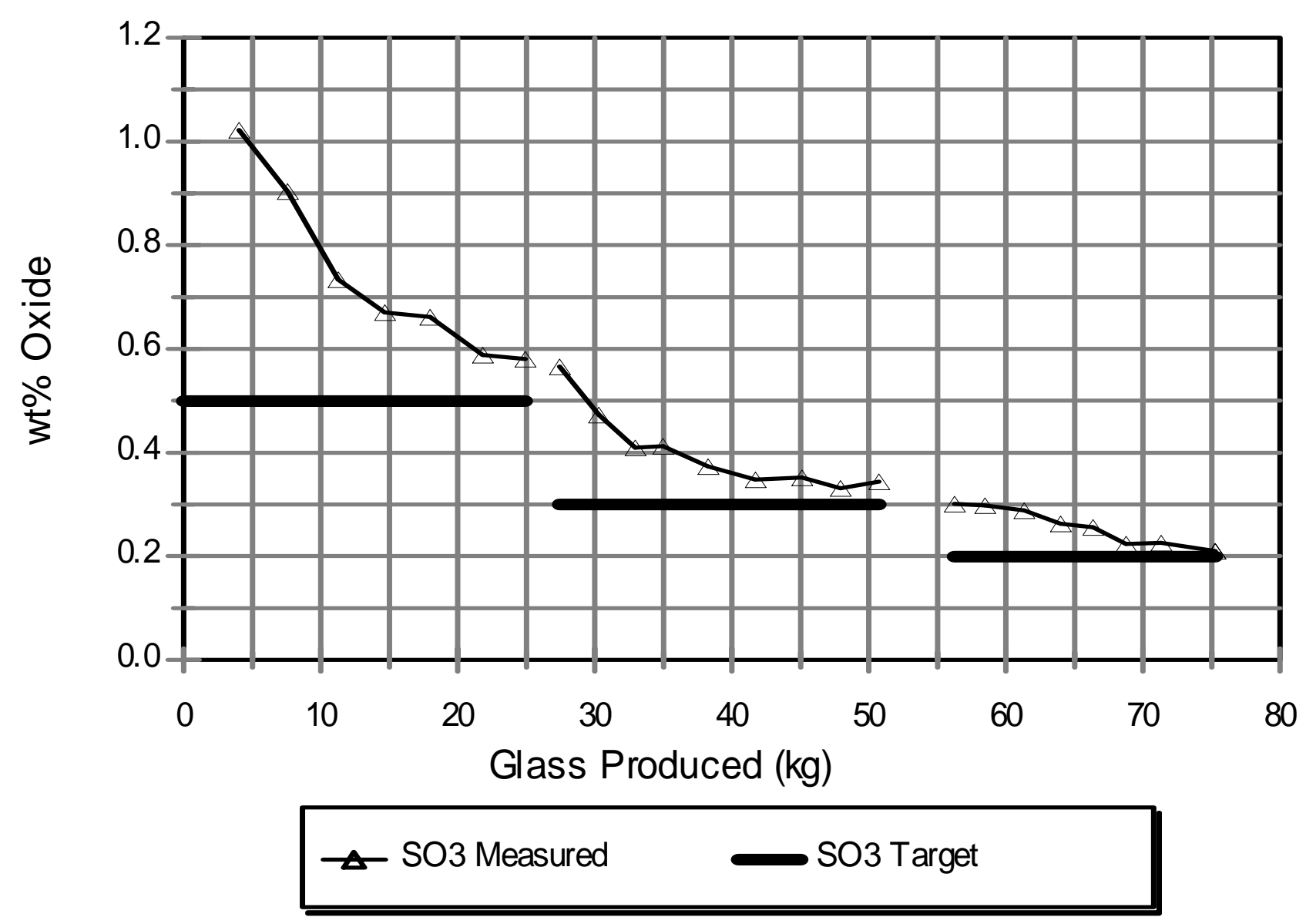

Figure 3.3.d. XRF analysis of sulfur in DM10 product glasses from Test G. (See Table 4.2 and Section 4.1 for details of composition analysis) 

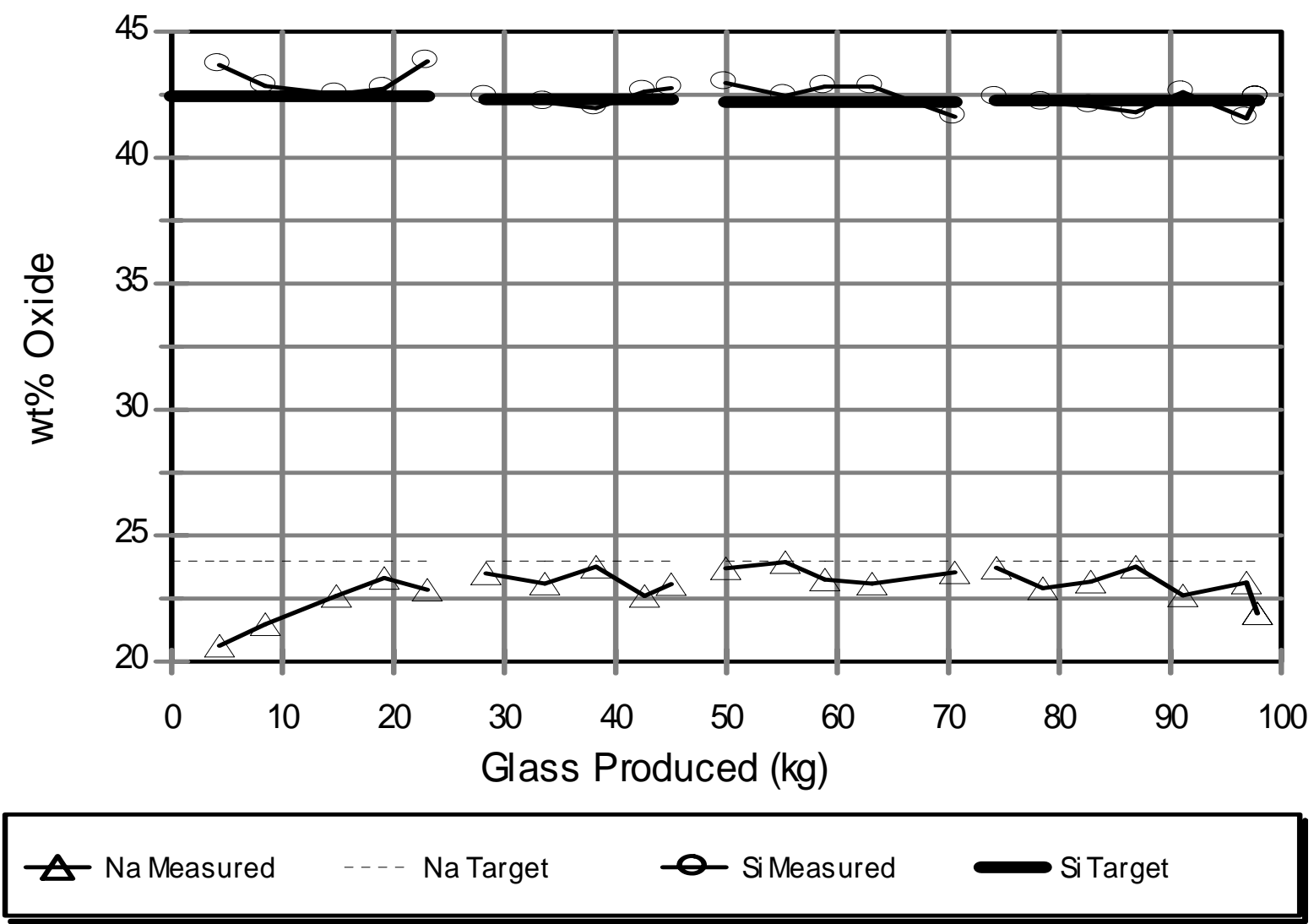

Figure 4.1.a. XRF analysis of sodium and silicon in DM10 product glasses from Test A. (See Table 4.2 and Section 4.1 for details of composition analysis) 


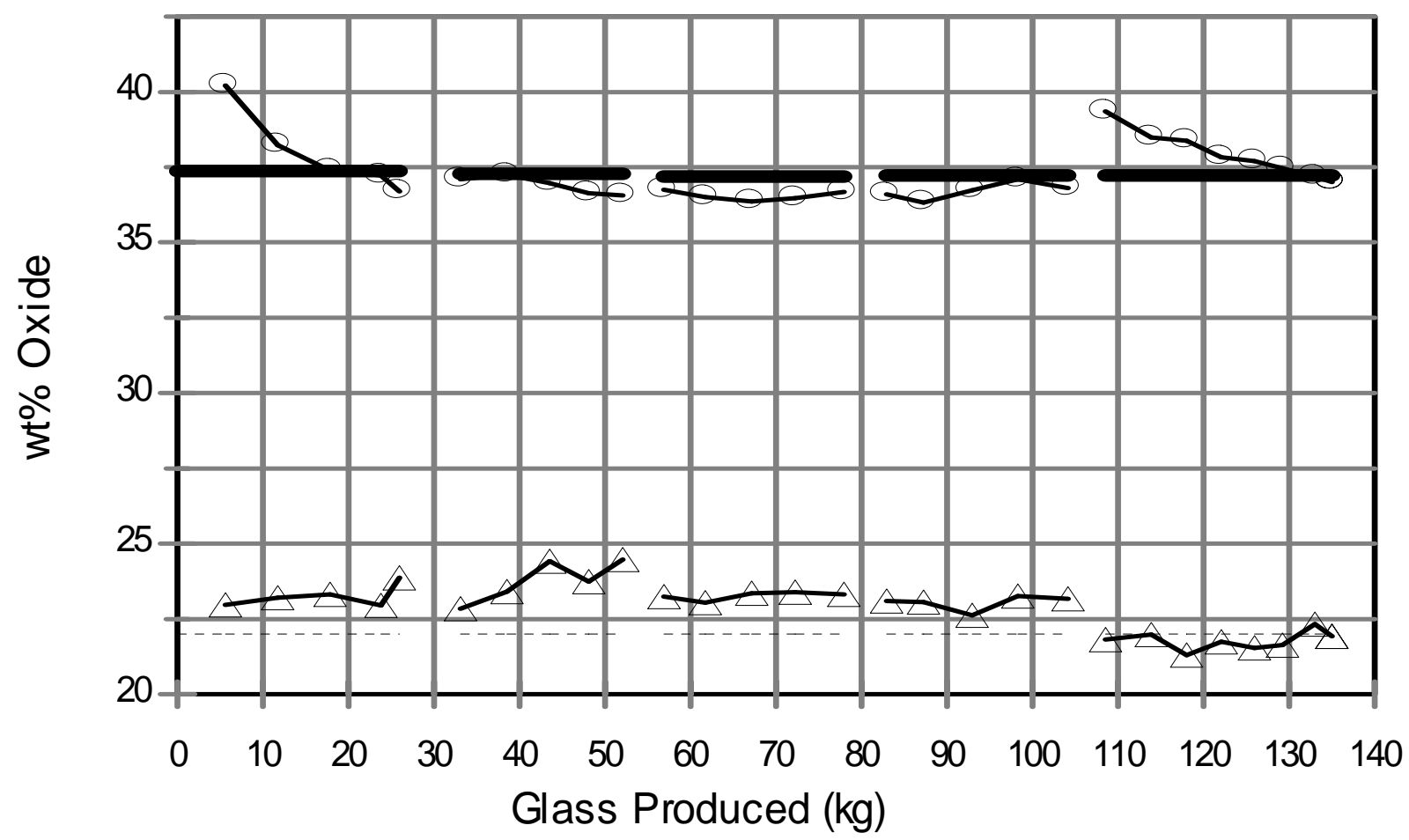
$\boldsymbol{\Delta}$ Na Measured
Na Target
- Si Measured
Si Target

Figure 4.1.b. XRF analysis of sodium and silica in DM10 product glasses from Test D. Note: Other testing and therefore melt pool turnover occurred between the fourth and fifth test segment shown.

(See Table 4.2 and Section 4.1 for details of composition analysis) 


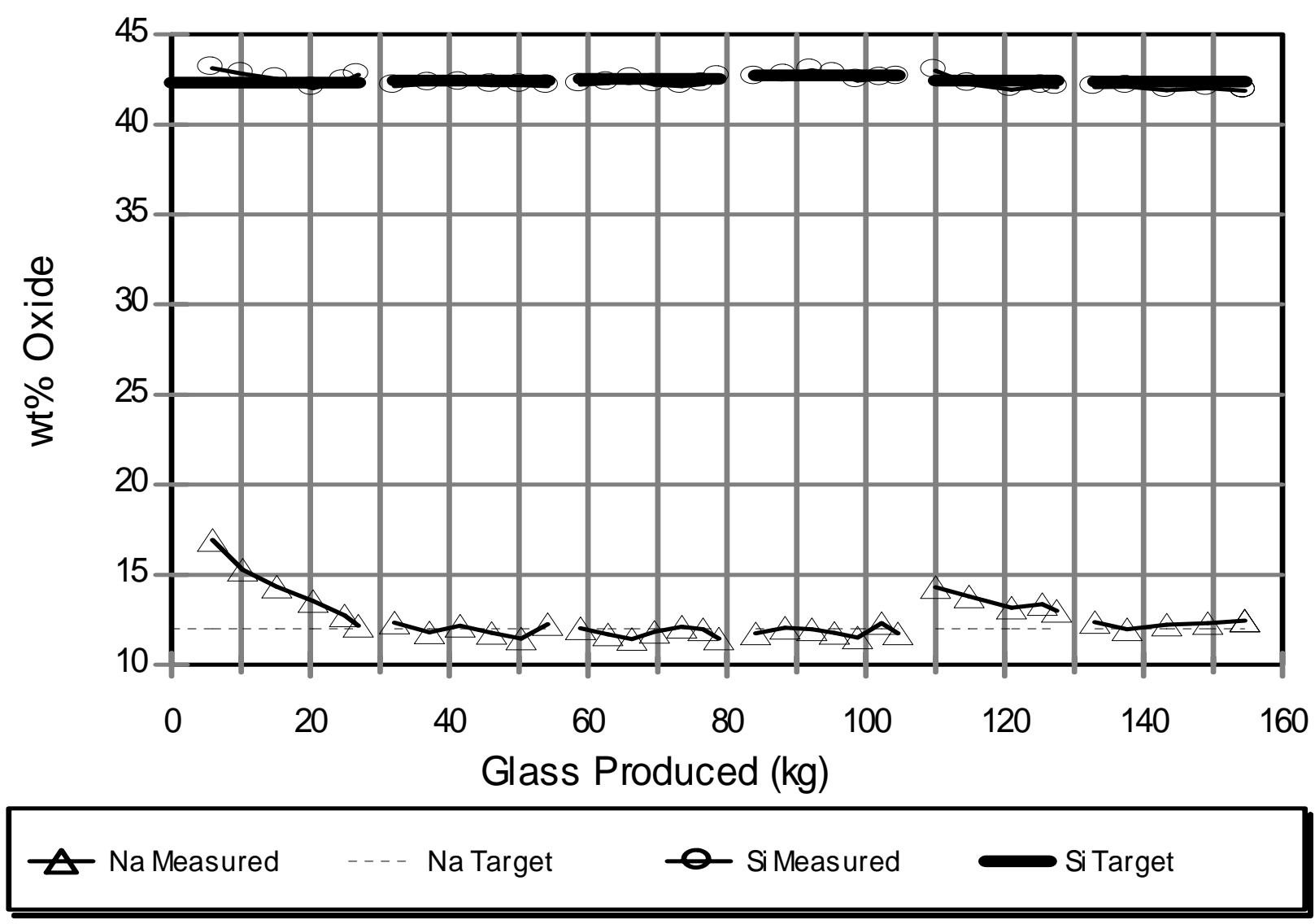

Figure 4.1.c. XRF analysis of sodium and silica in DM10 product glasses from Test F. Note: Other testing and therefore melt pool turnover occurred between the fourth and fifth test segment shown.

(See Table 4.2 and Section 4.1 for details of composition analysis) 


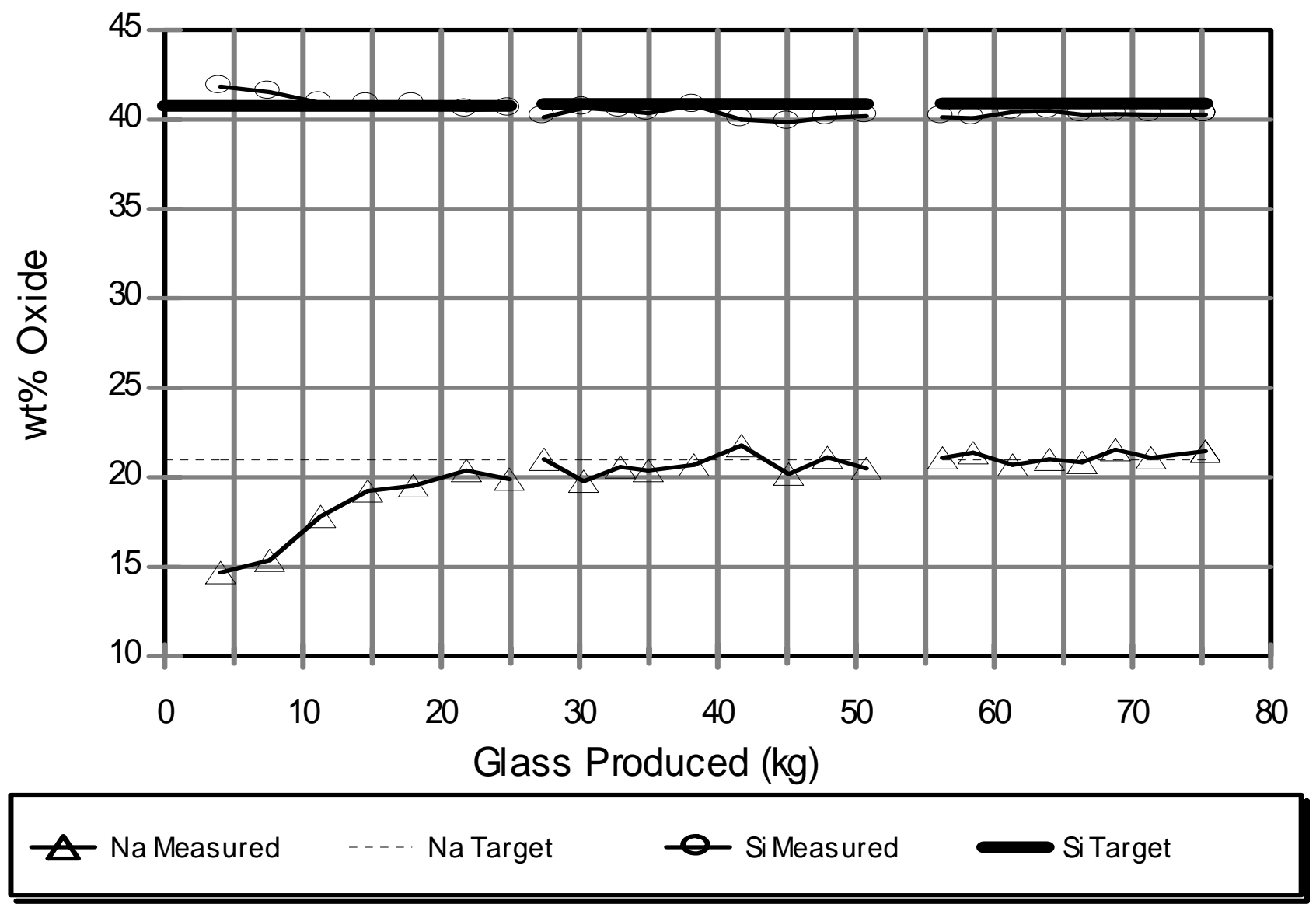

Figure 4.1.d. XRF analysis of sodium and silicon in DM10 product glasses from Test G. (See Table 4.2 and Section 4.1 for details of composition analysis) 

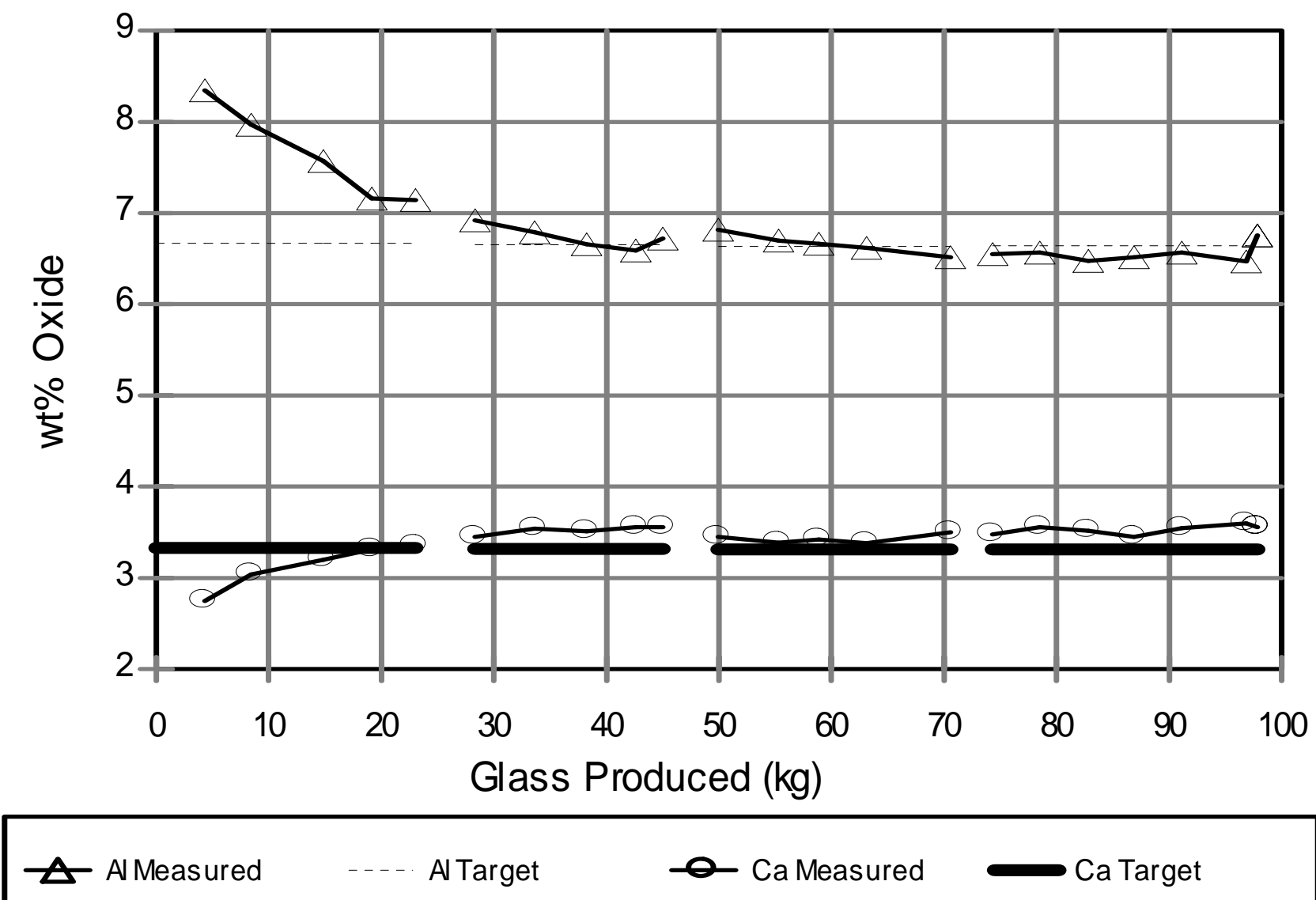

Figure 4.2.a. XRF analysis of aluminum and calcium in DM10 product glasses from Test A. (See Table 4.2 and Section 4.1 for details of composition analysis) 


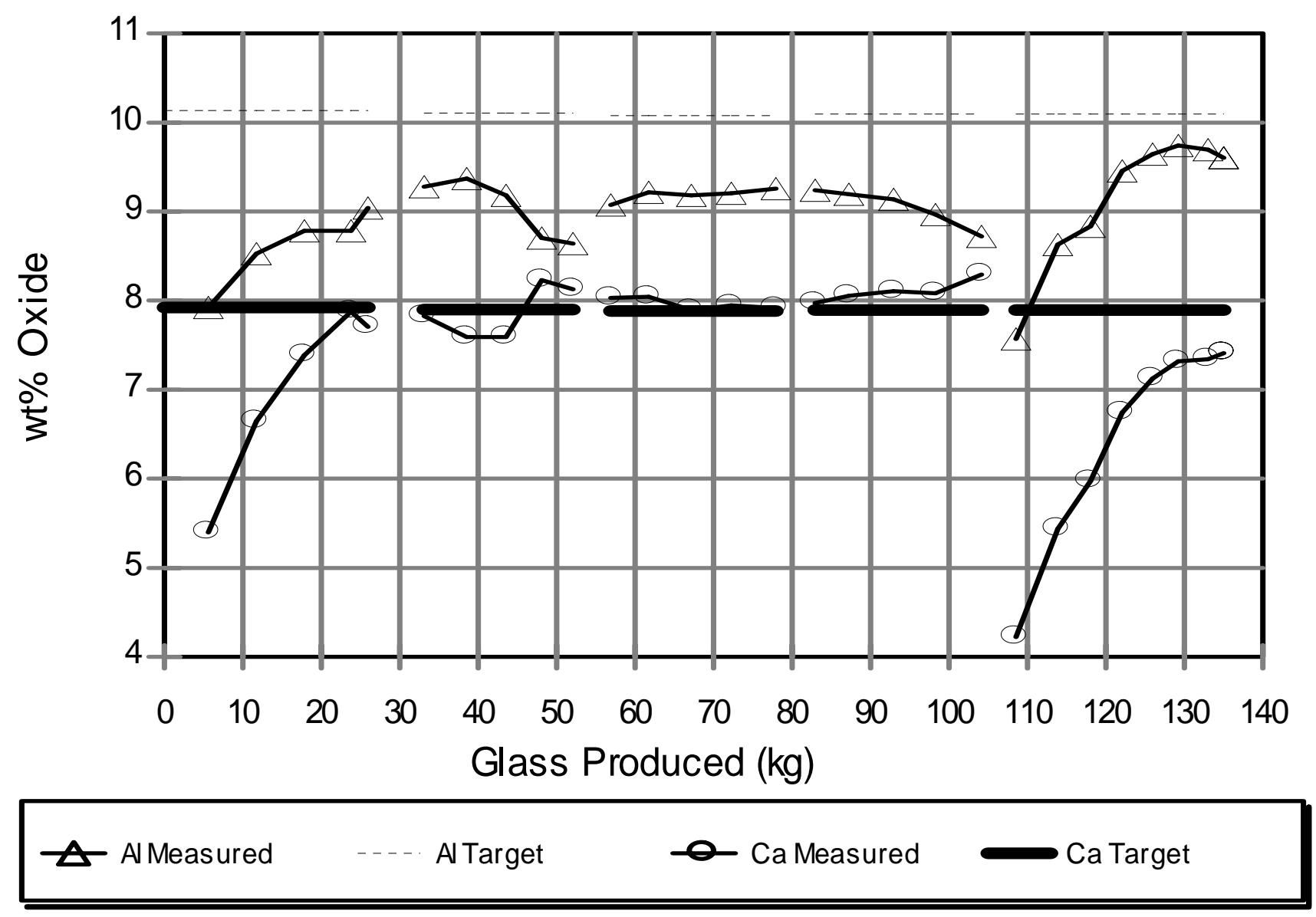

Figure 4.2.b. XRF analysis of aluminum and calcium in DM10 product glasses from Test D. Note: Other testing and therefore melt pool turnover occurred between the fourth and fifth test segment shown.

(See Table 4.2 and Section 4.1 for details of composition analysis) 


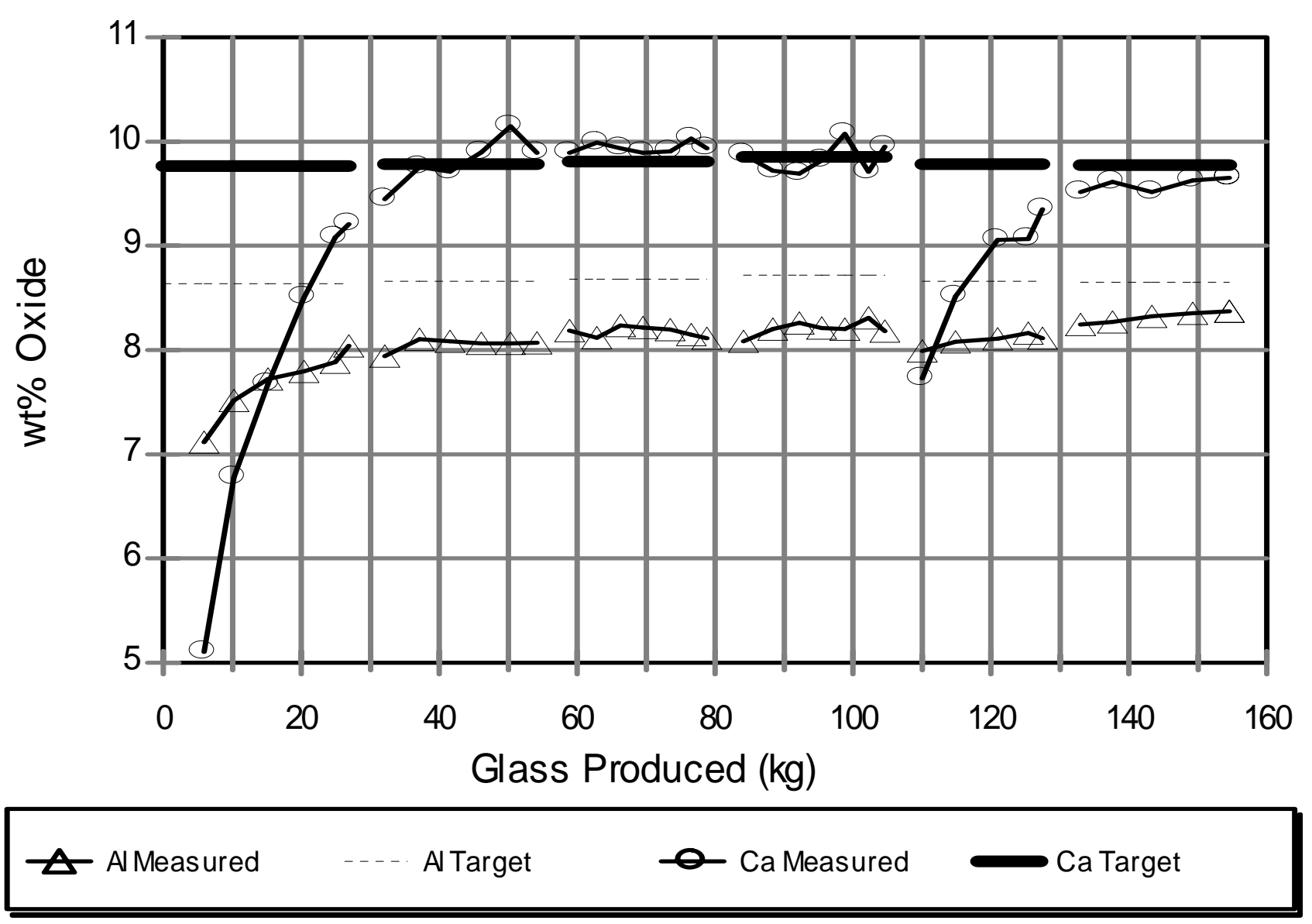

Figure 4.2.c. XRF analysis of aluminum and calcium in DM10 product glasses from Test F. Note: Other testing and therefore melt pool turnover occurred between the fourth and fifth test segment shown.

(See Table 4.2 and Section 4.1 for details of composition analysis) 

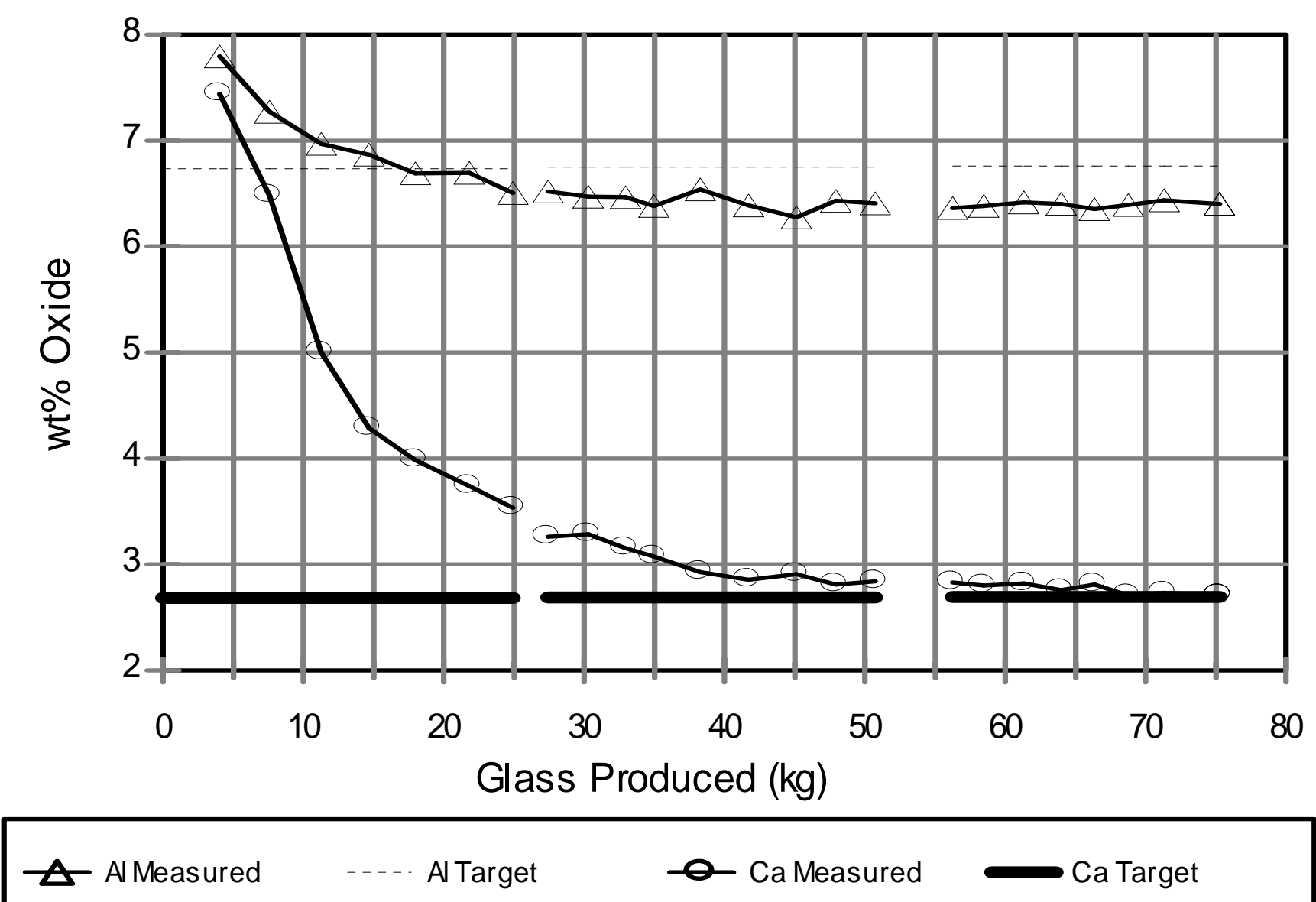

Figure 4.2.d. XRF analysis of aluminum and calcium in DM10 product glasses from Test G. (See Table 4.2 and Section 4.1 for details of composition analysis) 


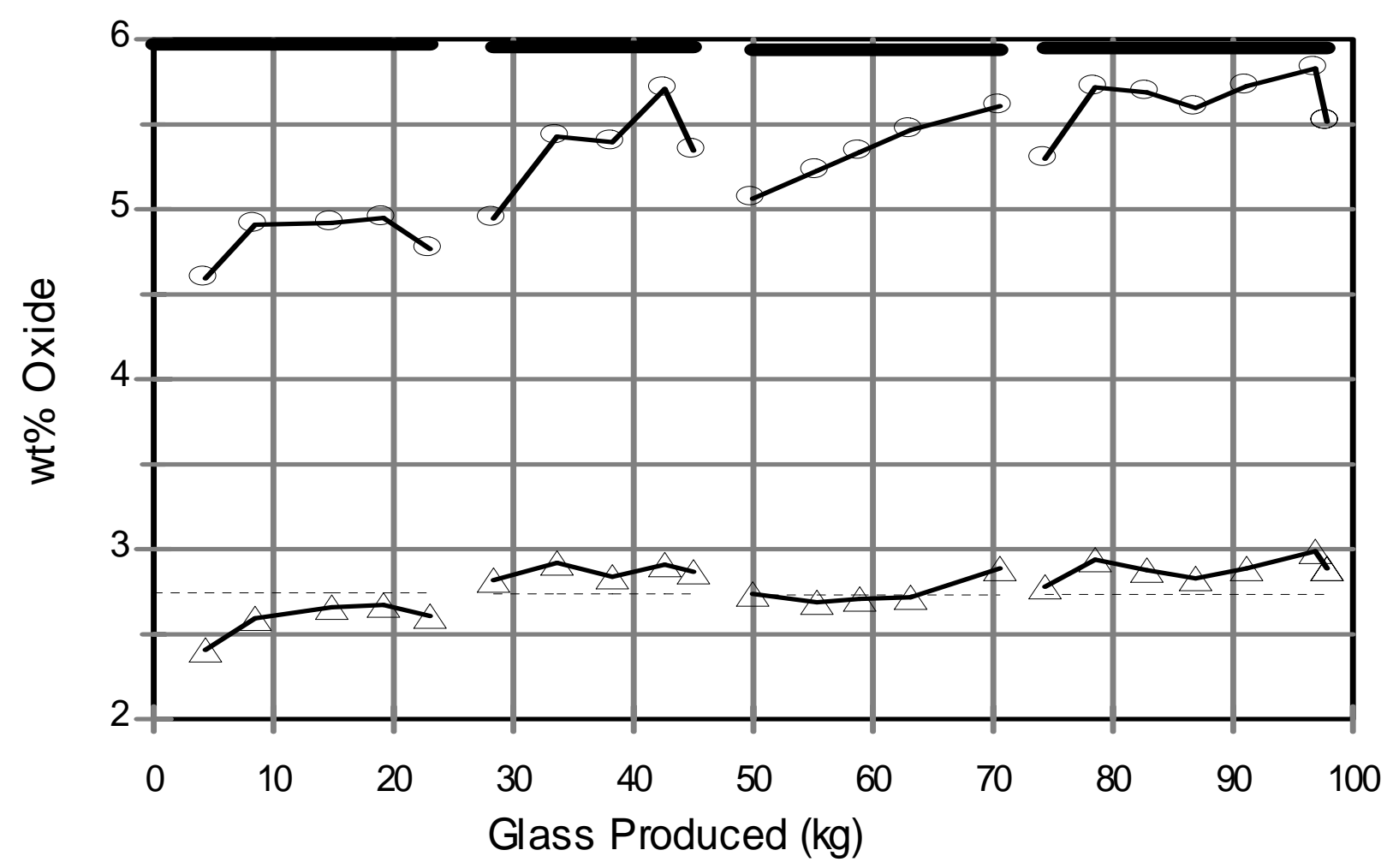

An Measured

Zn Target

- Zr Measured

Zr Target

Figure 4.3.a. XRF analysis of zinc and zirconium in DM10 product glasses from Test $A$. (See Table 4.2 and Section 4.1 for details of composition analysis) 


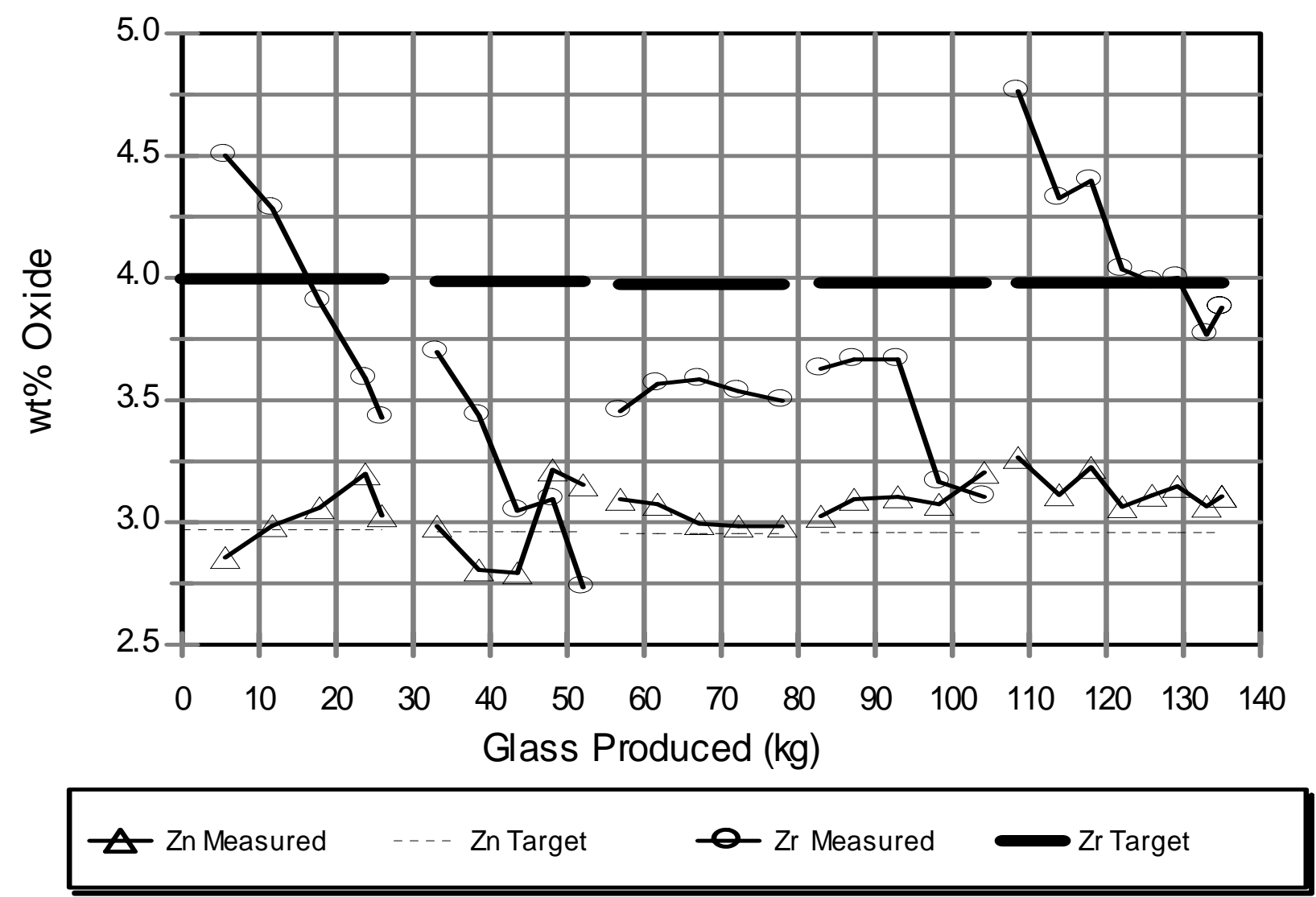

Figure 4.3.b. XRF analysis of zinc and zirconium in DM10 product glasses from Test D. Note: Other testing and therefore melt pool turnover occurred between the fourth and fifth test segment shown.

(See Table 4.2 and Section 4.1 for details of composition analysis) 


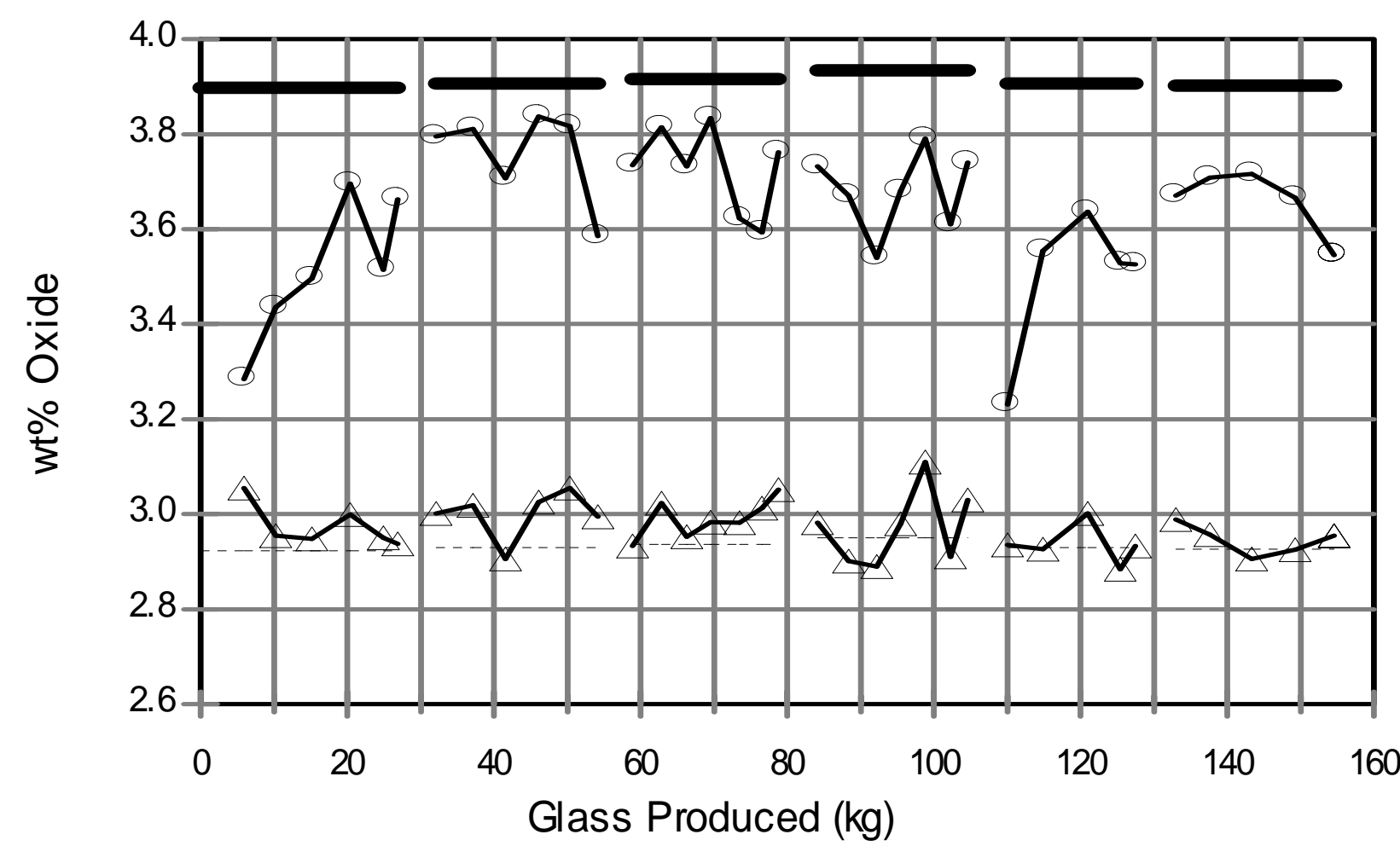
$\widehat{A}$ Zn Measured
Zn Target
- Zr Measured
Zr Target

Figure 4.3.c. XRF analysis of zinc and zirconium in DM10 product glasses from Test F. Note: Other testing and therefore melt pool turnover occurred between the fourth and fifth test segment shown.

(See Table 4.2 and Section 4.1 for details of composition analysis) 


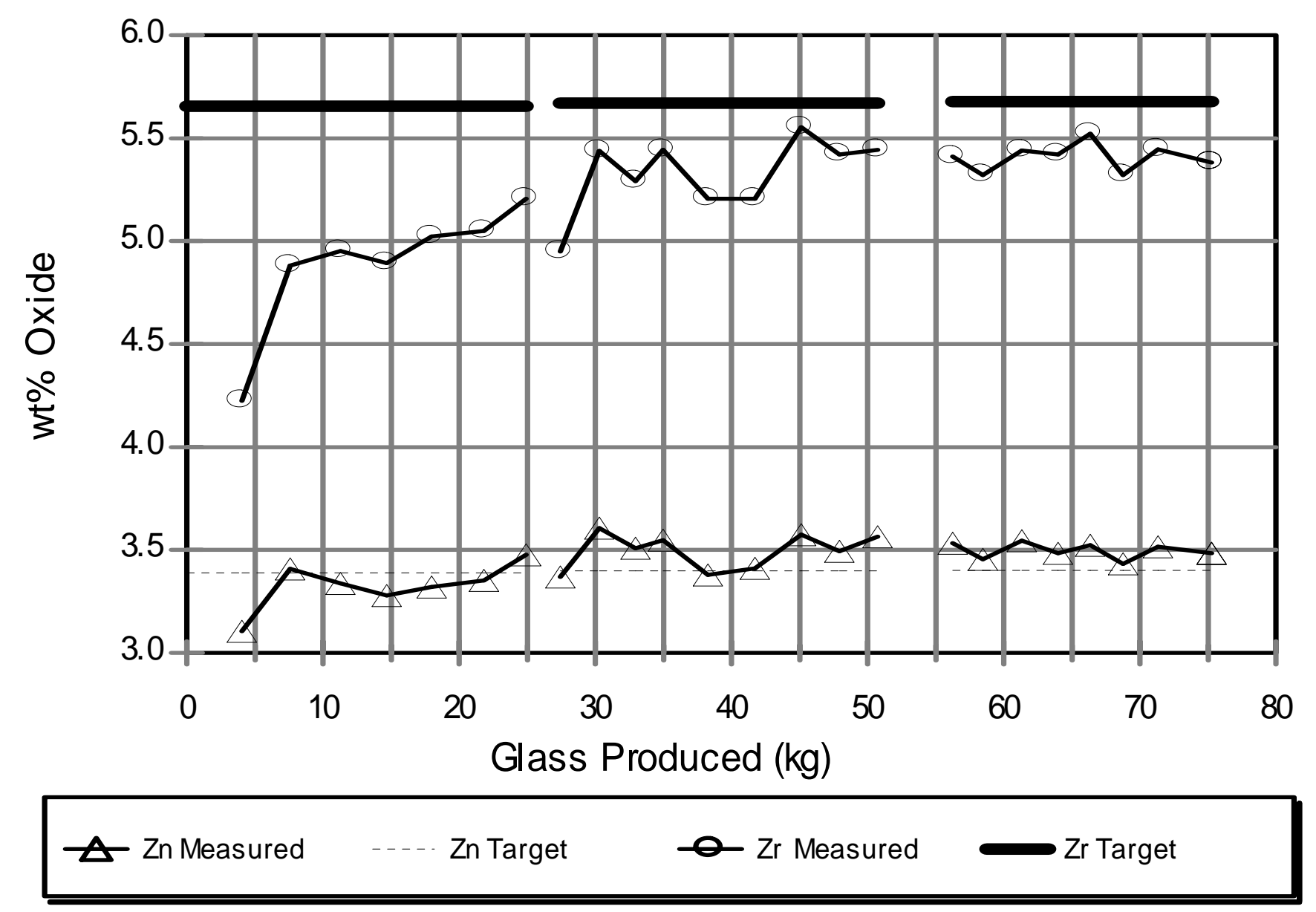

Figure 4.3.d. XRF analysis of zinc and zirconium in DM10 product glasses from Test G. (See Table 4.2 and Section 4.1 for details of composition analysis) 

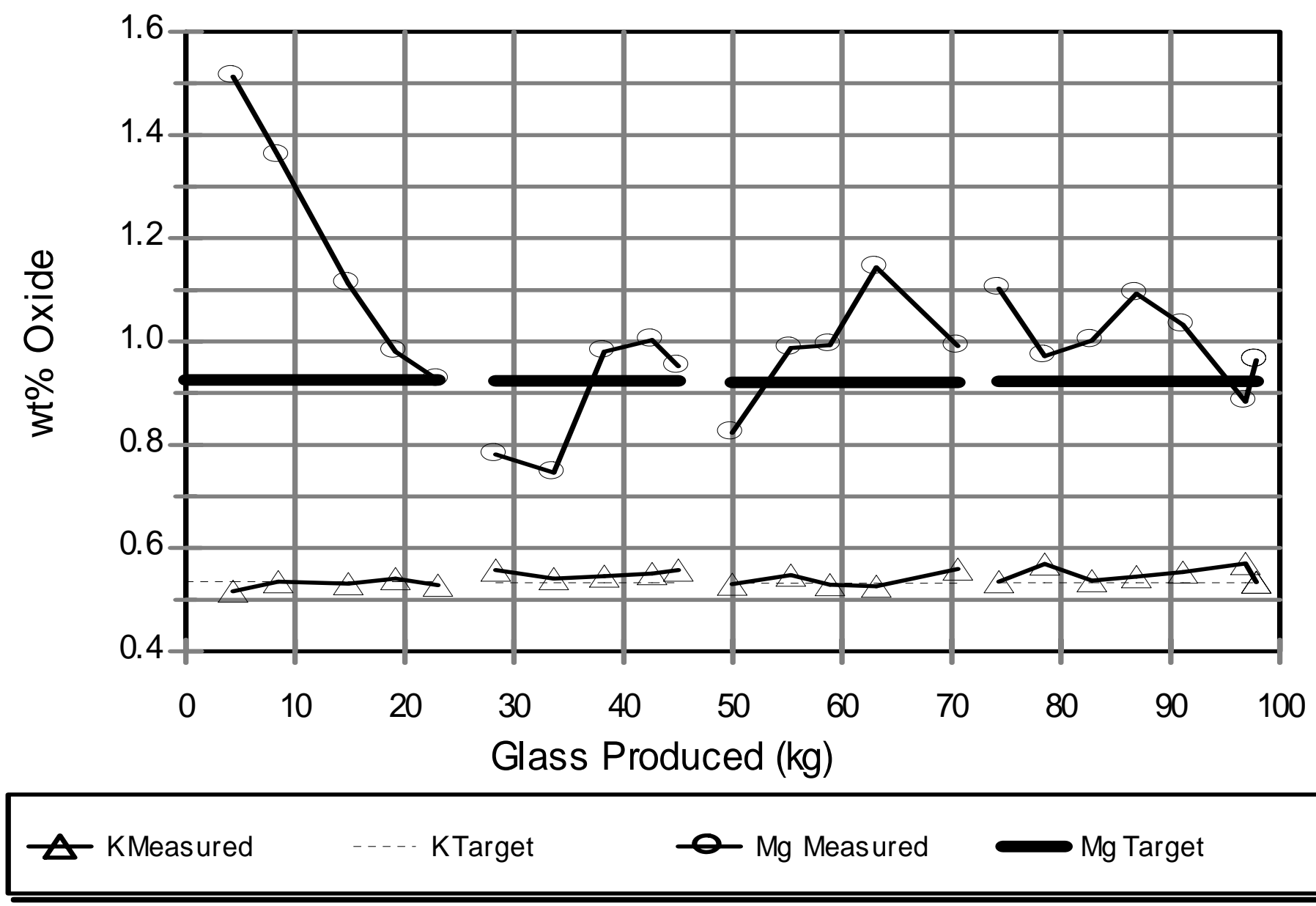

Figure 4.4.a. XRF analysis of potassium and magnesium in DM10 product glasses from Test A. (See Table 4.2 and Section 4.1 for details of composition analysis) 


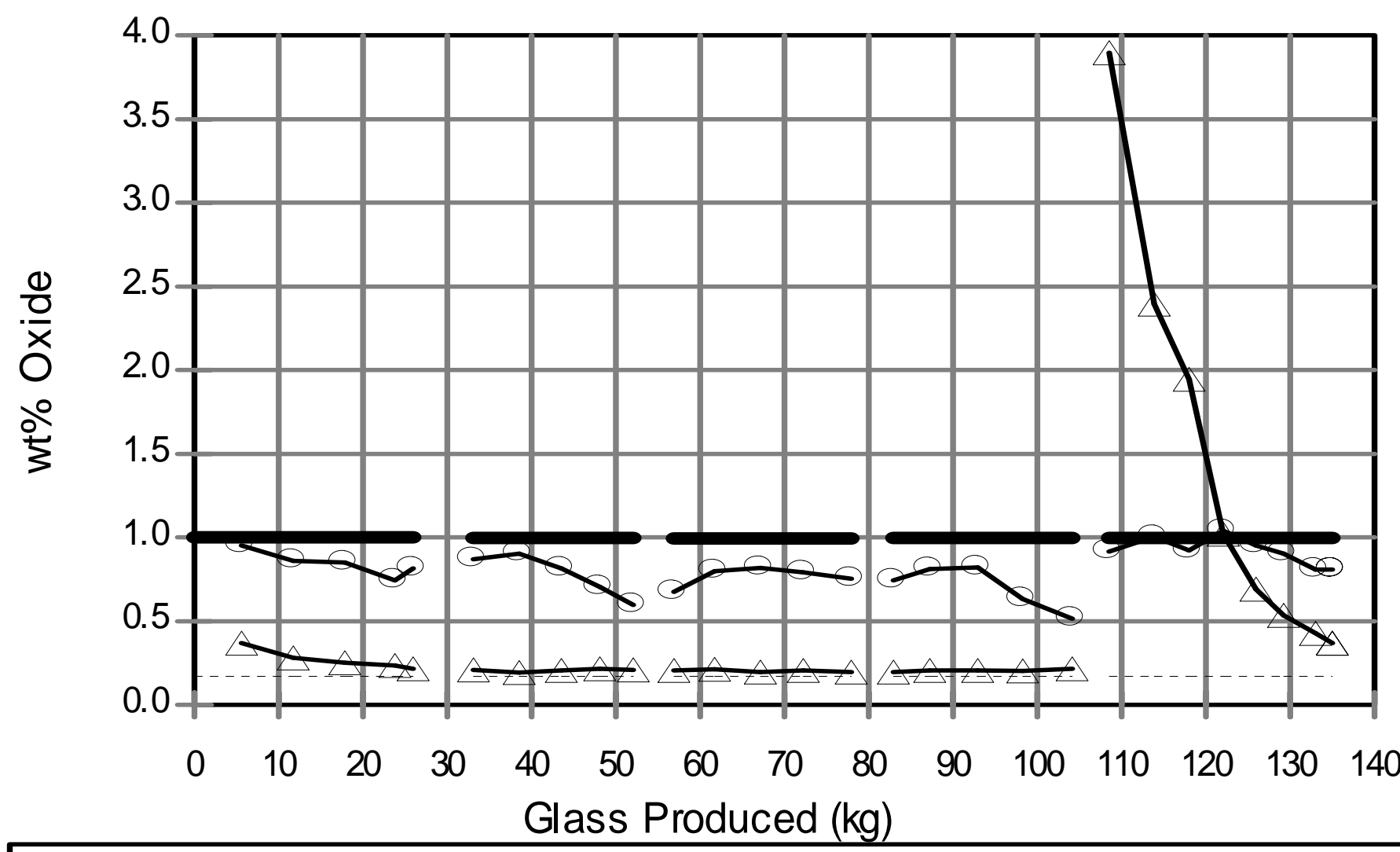
$\boldsymbol{A}$ KMeasured
-.... KTarget
-
Mg Target

Figure 4.4.b. XRF analysis of potassium and magnesium in DM10 product glasses from Test D. Note: Other testing and therefore melt pool turnover occurred between the fourth and fifth test segment shown.

(See Table 4.2 and Section 4.1 for details of composition analysis) 


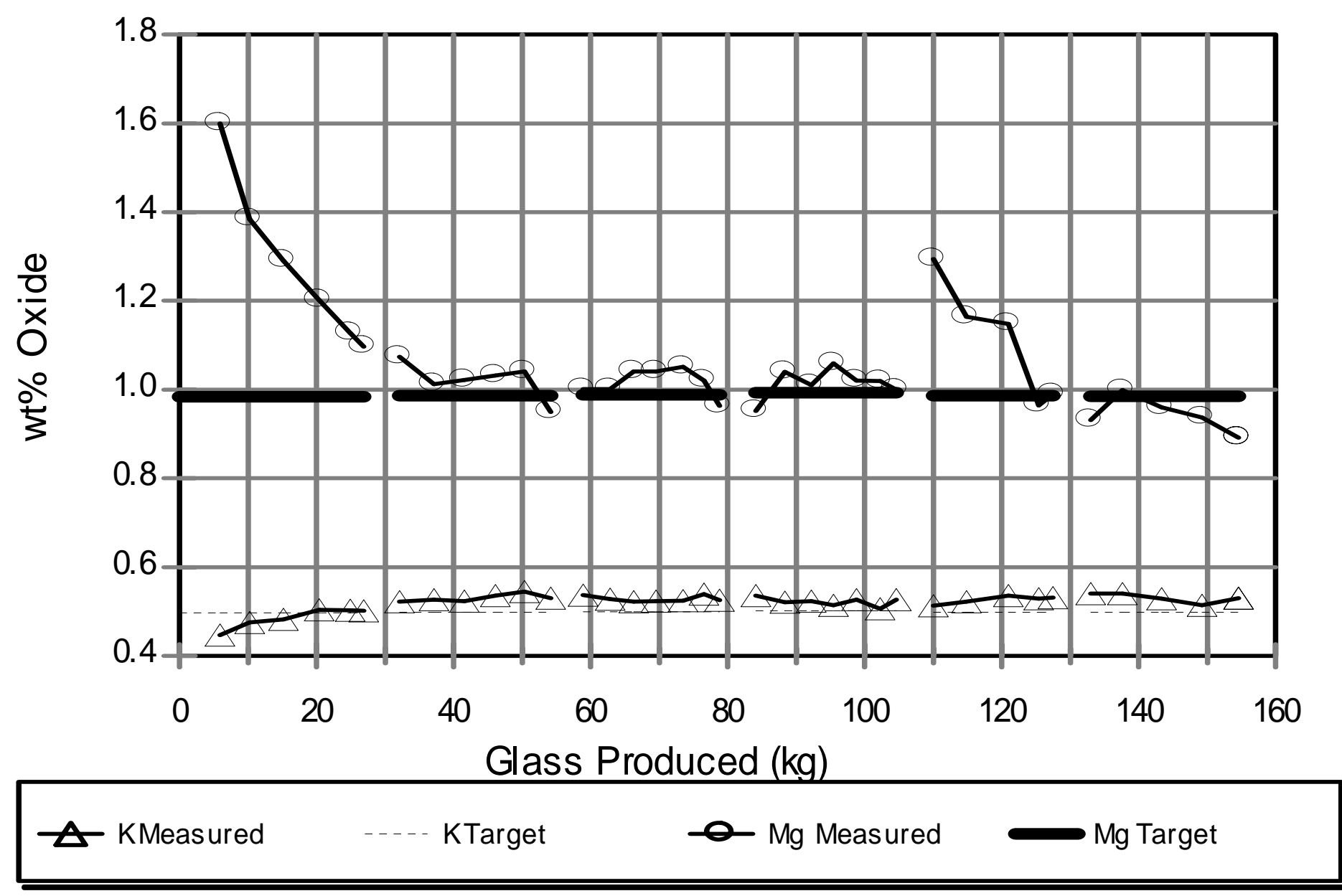

Figure 4.4.c. XRF analysis of potassium and magnesium in DM10 product glasses from Test F. Note: Other testing and therefore melt pool turnover occurred between the fourth and fifth test segment shown.

(See Table 4.2 and Section 4.1 for details of composition analysis) 


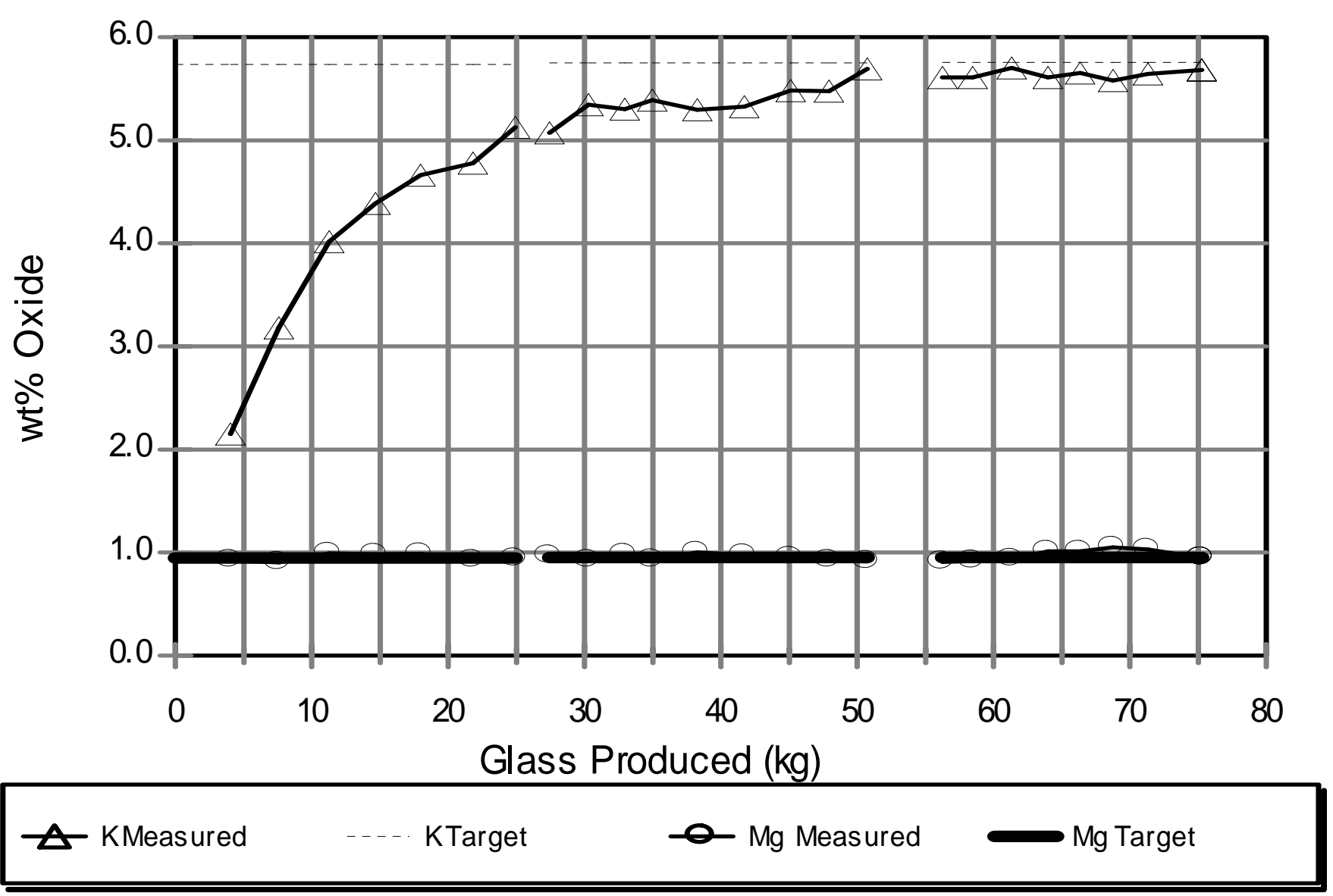

Figure 4.4.d. XRF analysis of potassium and magnesium in DM10 product glasses from Test G. (See Table 4.2 and Section 4.1 for details of composition analysis) 


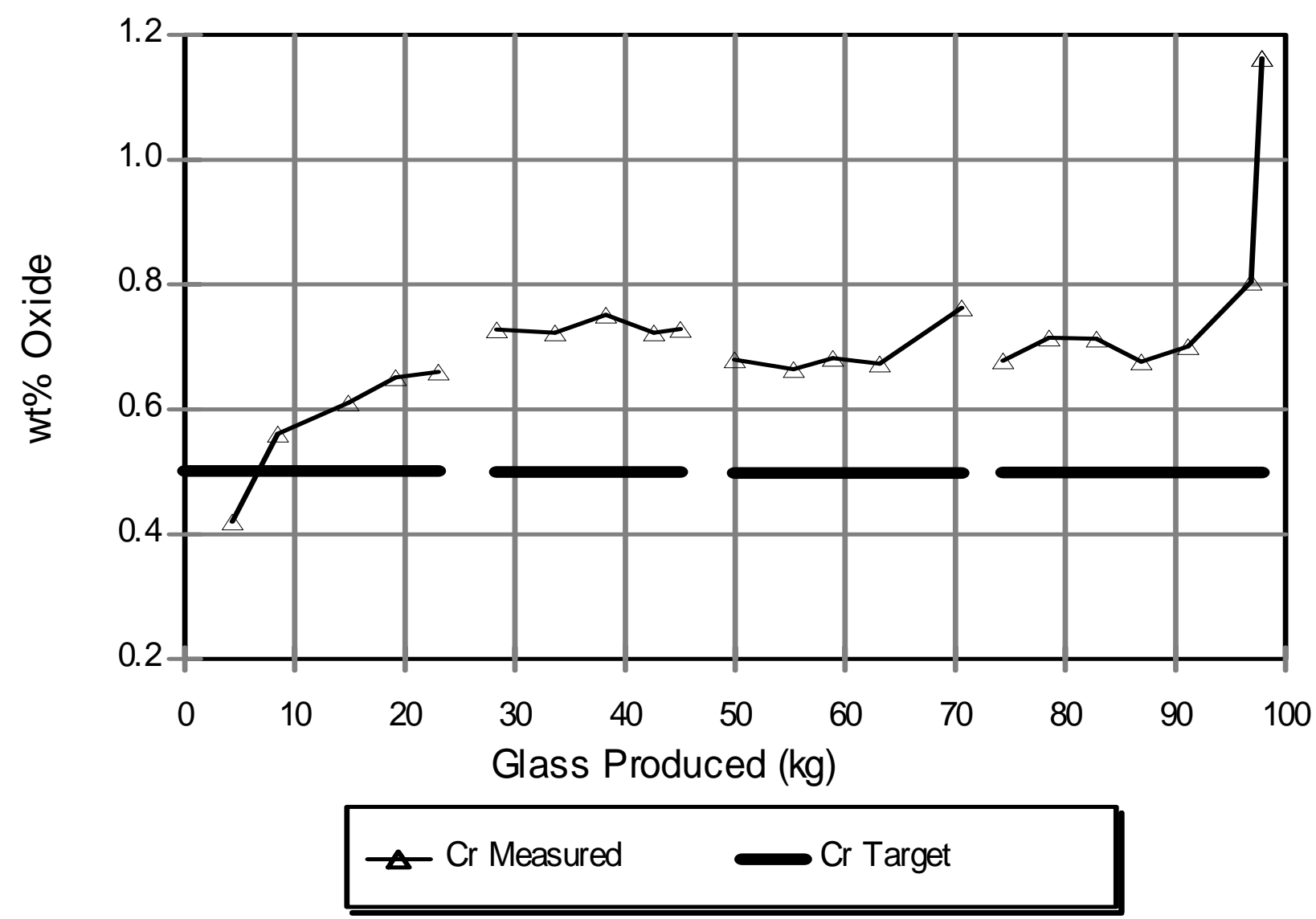

Figure 4.5.a. XRF analysis of chromium in DM10 product glasses from Test A. (See Table 4.2 and Section 4.1 for details of composition analysis) 

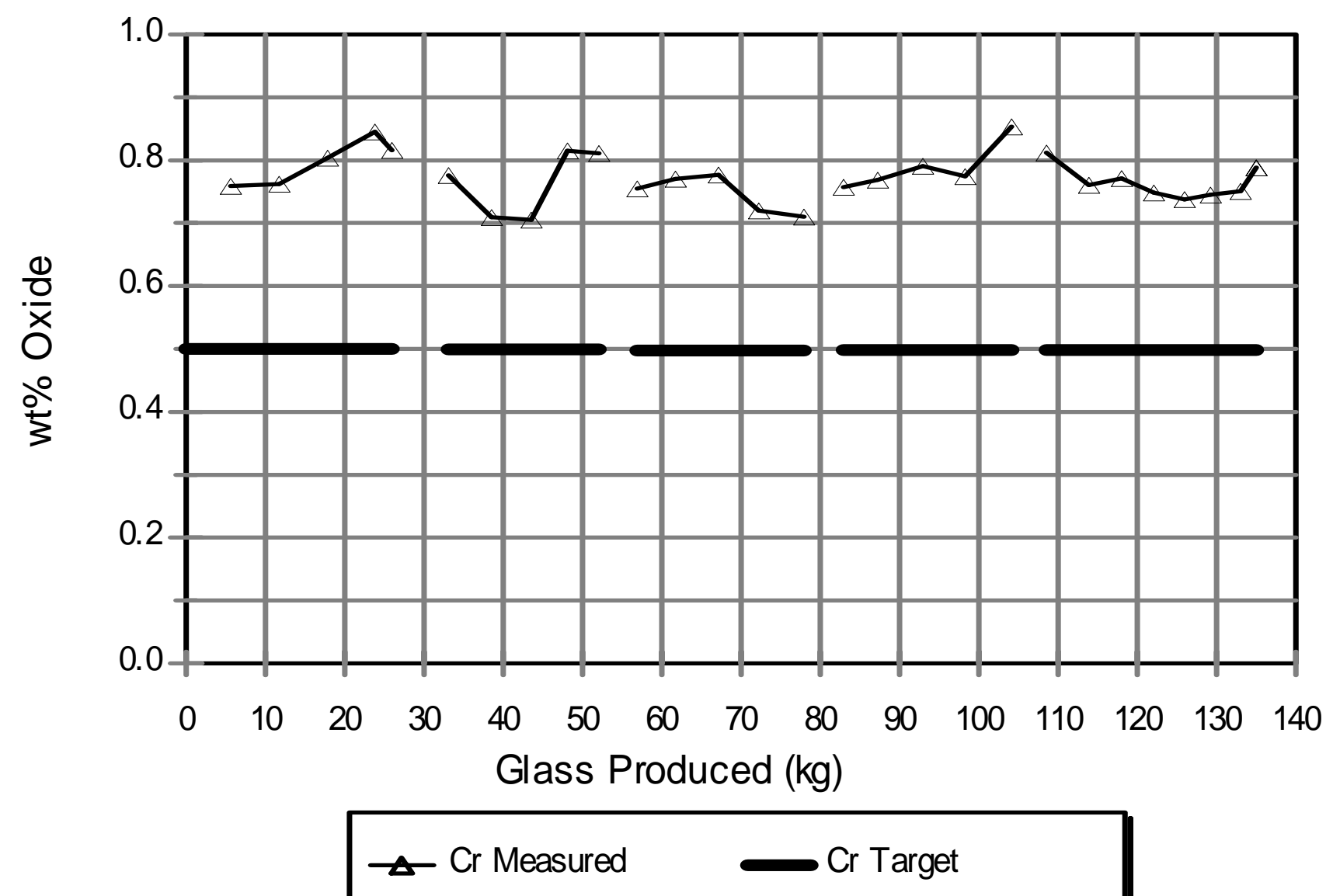

Figure 4.5.b. XRF analysis of chromium in DM10 product glasses from Test D. Note: Other testing and therefore melt pool turnover occurred between the fourth and fifth test segment shown.

(See Table 4.2 and Section 4.1 for details of composition analysis) 


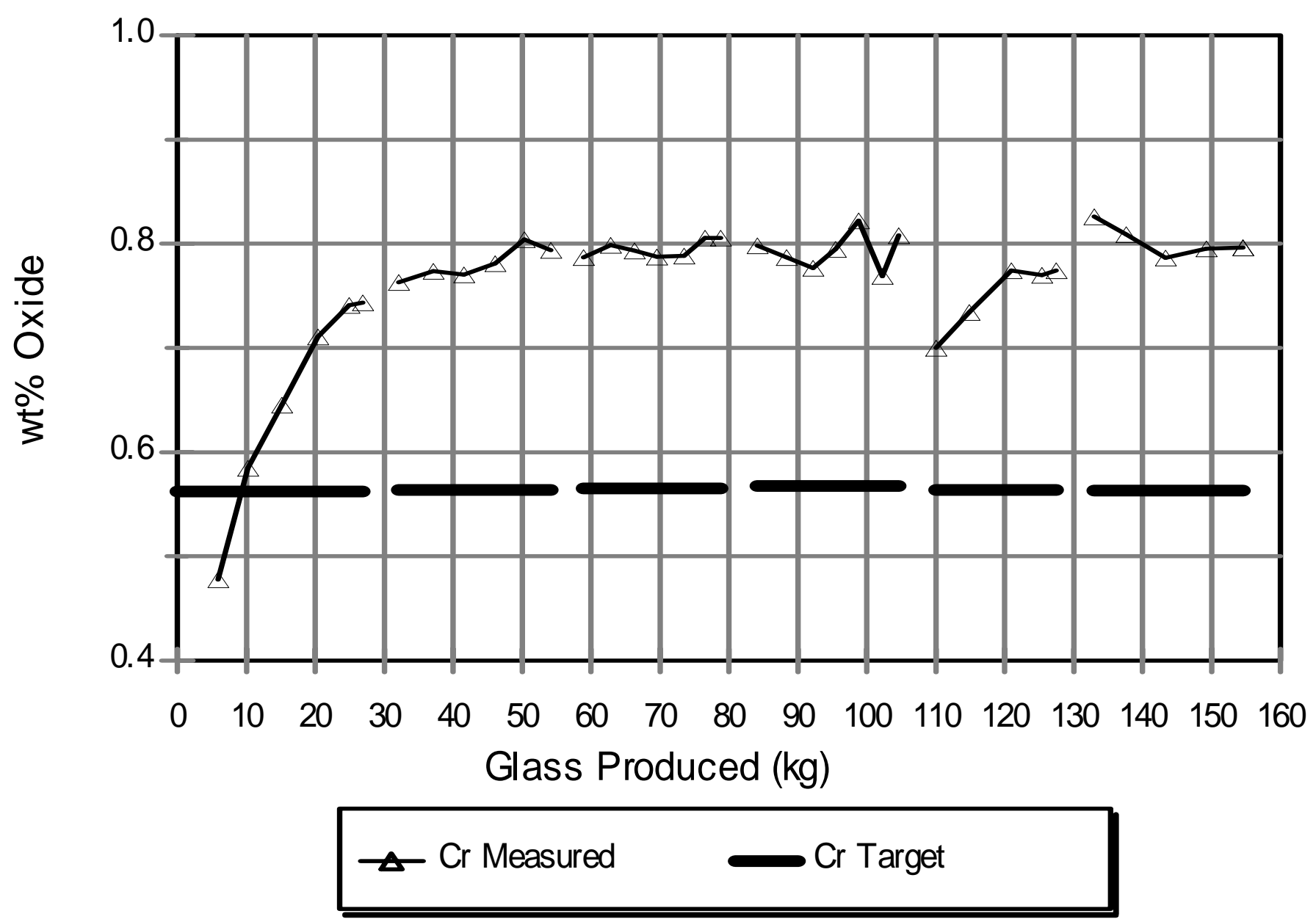

Figure 4.5.c. XRF analysis of chromium in DM10 product glasses from Test F. Note: Other testing and therefore melt pool turnover occurred between the fourth and fifth test segment shown.

(See Table 4.2 and Section 4.1 for details of composition analysis) 


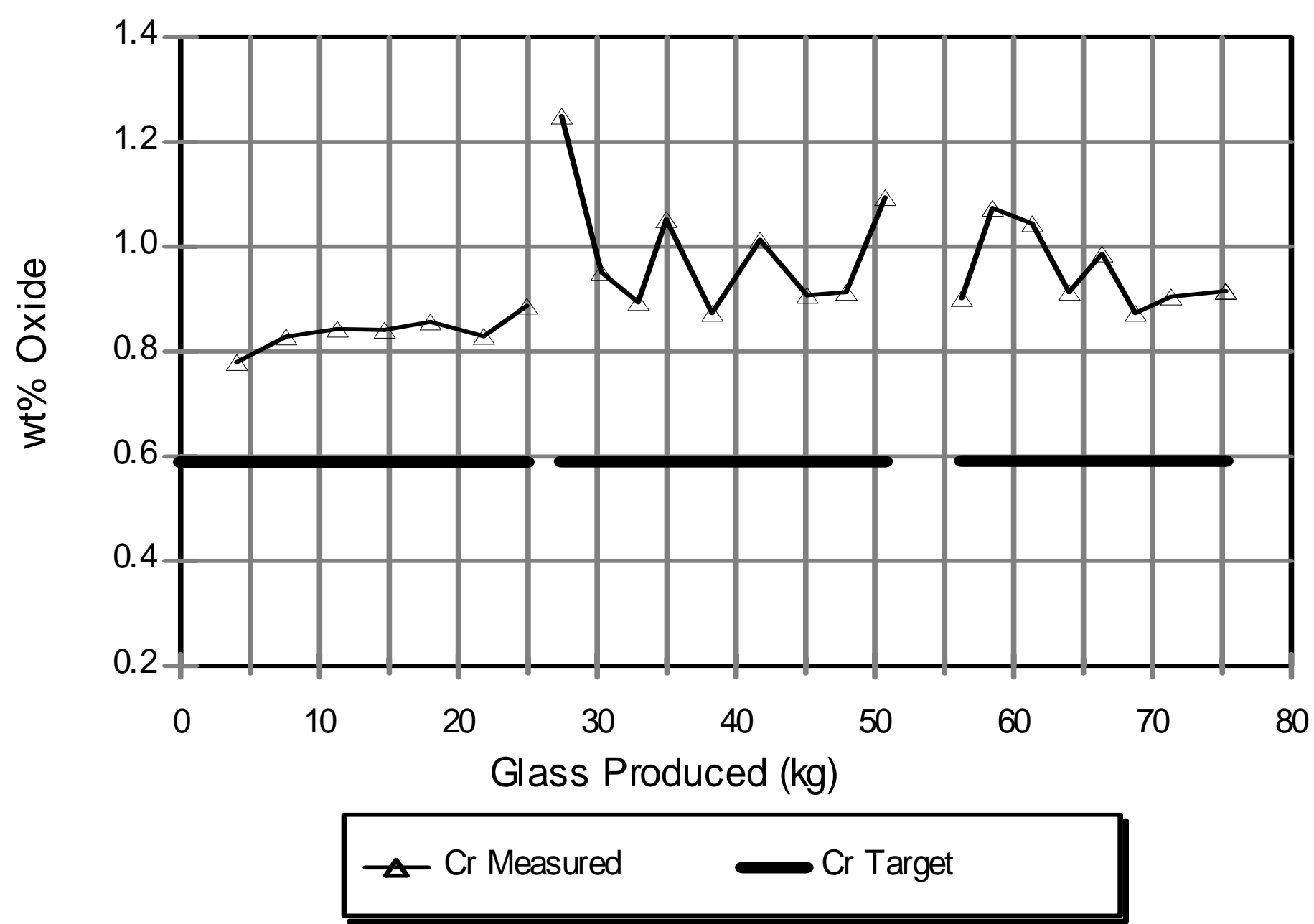

Figure 4.5.d. XRF analysis of chromium in DM10 product glasses from Test G. (See Table 4.2 and Section 4.1 for details of composition analysis) 


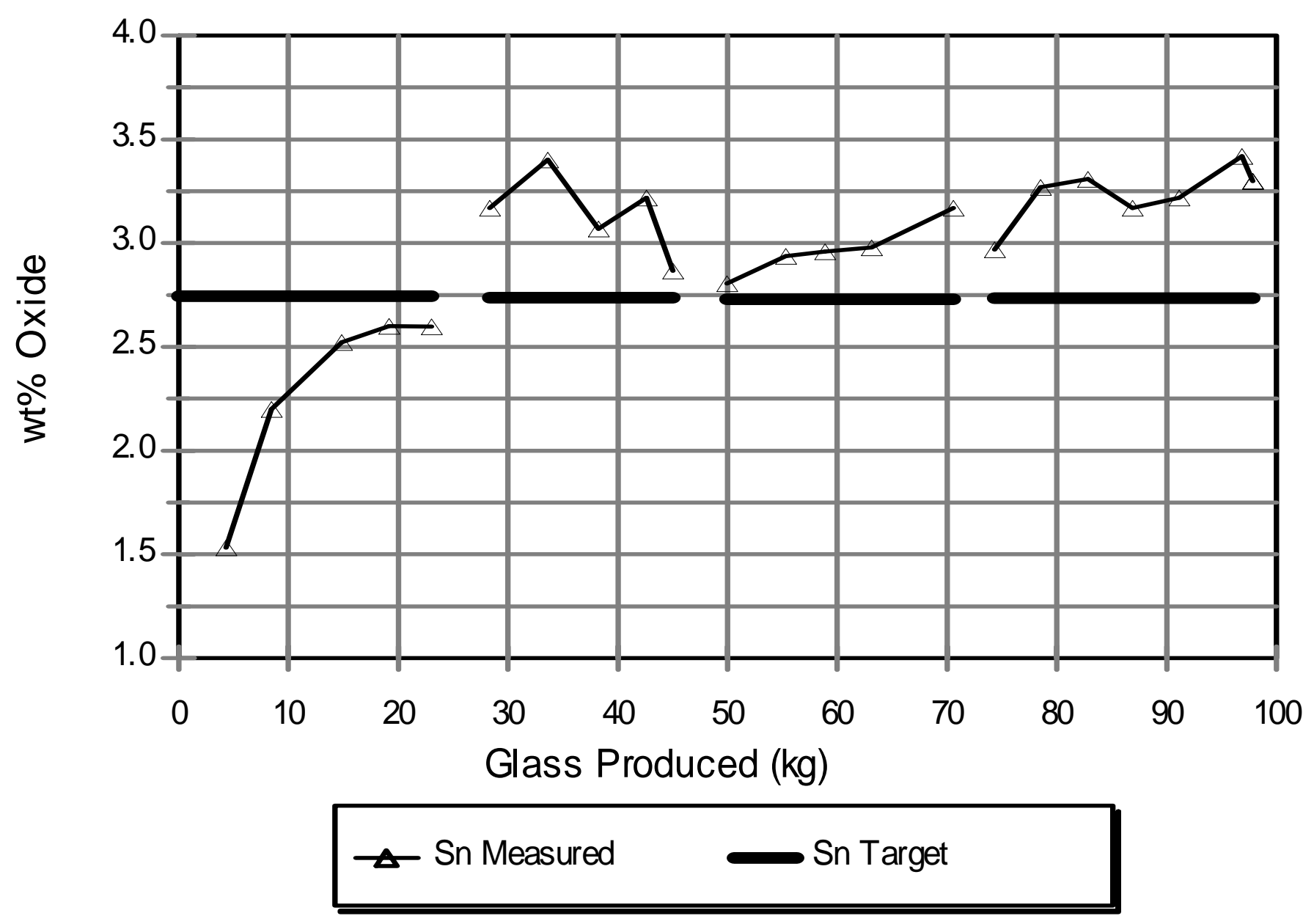

Figure 4.6.a. XRF analysis of tin in DM10 product glasses from Test A. (See Table 4.2 and Section 4.1 for details of composition analysis) 


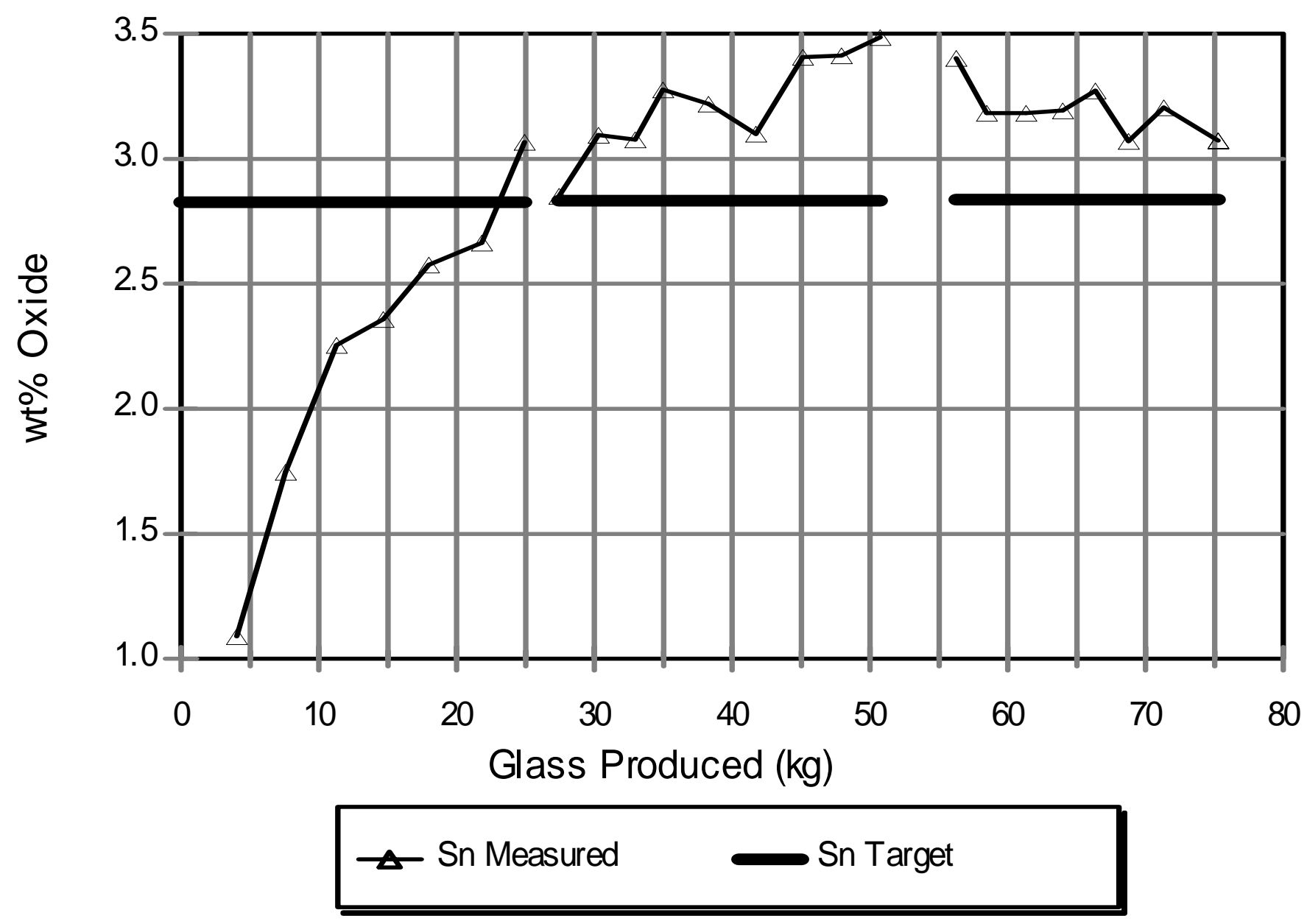

Figure 4.6.b. XRF analysis of tin in DM10 product glasses from Test G. (See Table 4.2 and Section 4.1 for details of composition analysis) 


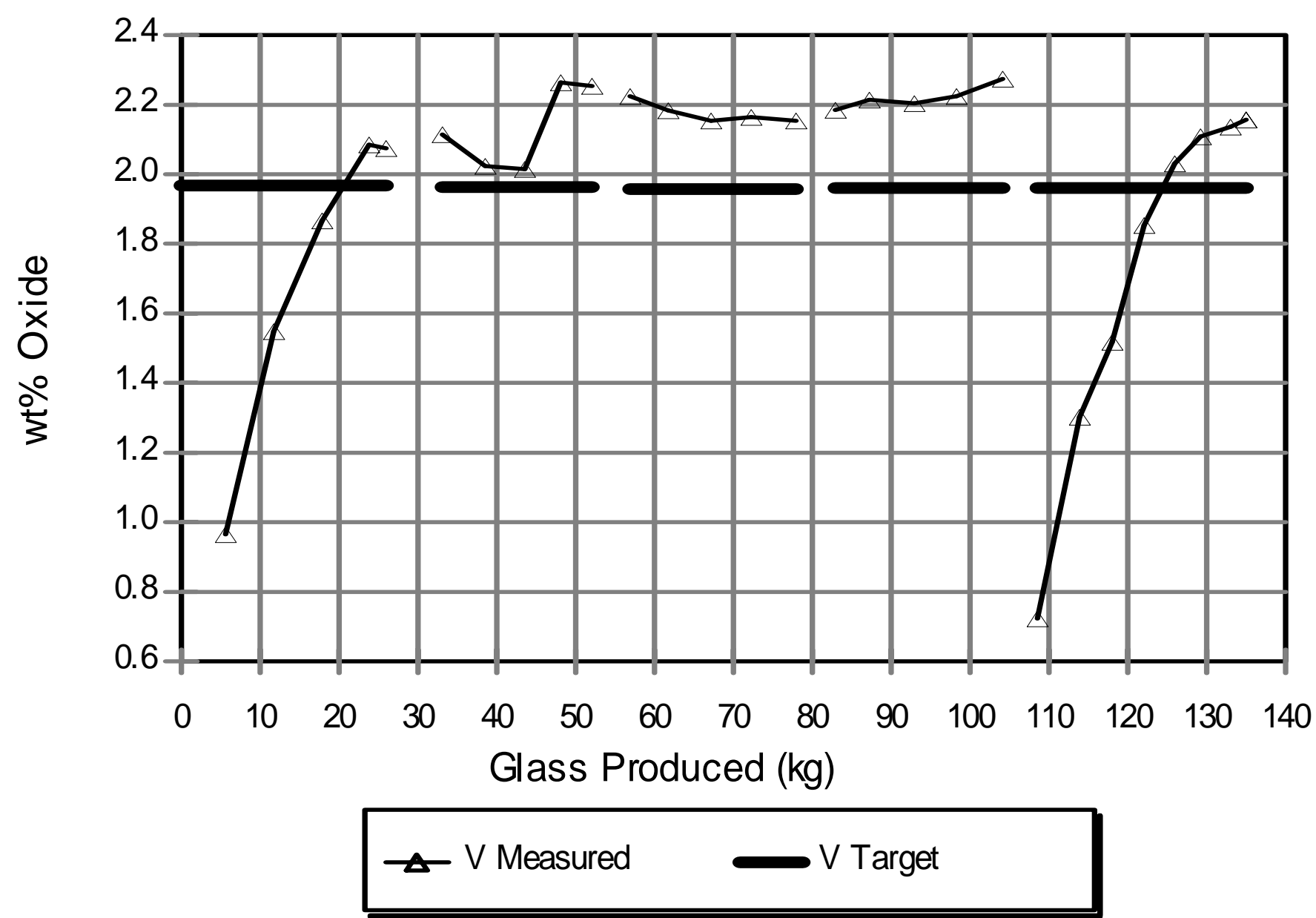

Figure 4.7.a. XRF analysis of vanadium in DM10 product glasses from Test D. Note: Other testing and therefore melt pool turnover occurred between the fourth and fifth test segment shown.

(See Table 4.2 and Section 4.1 for details of composition analysis) 

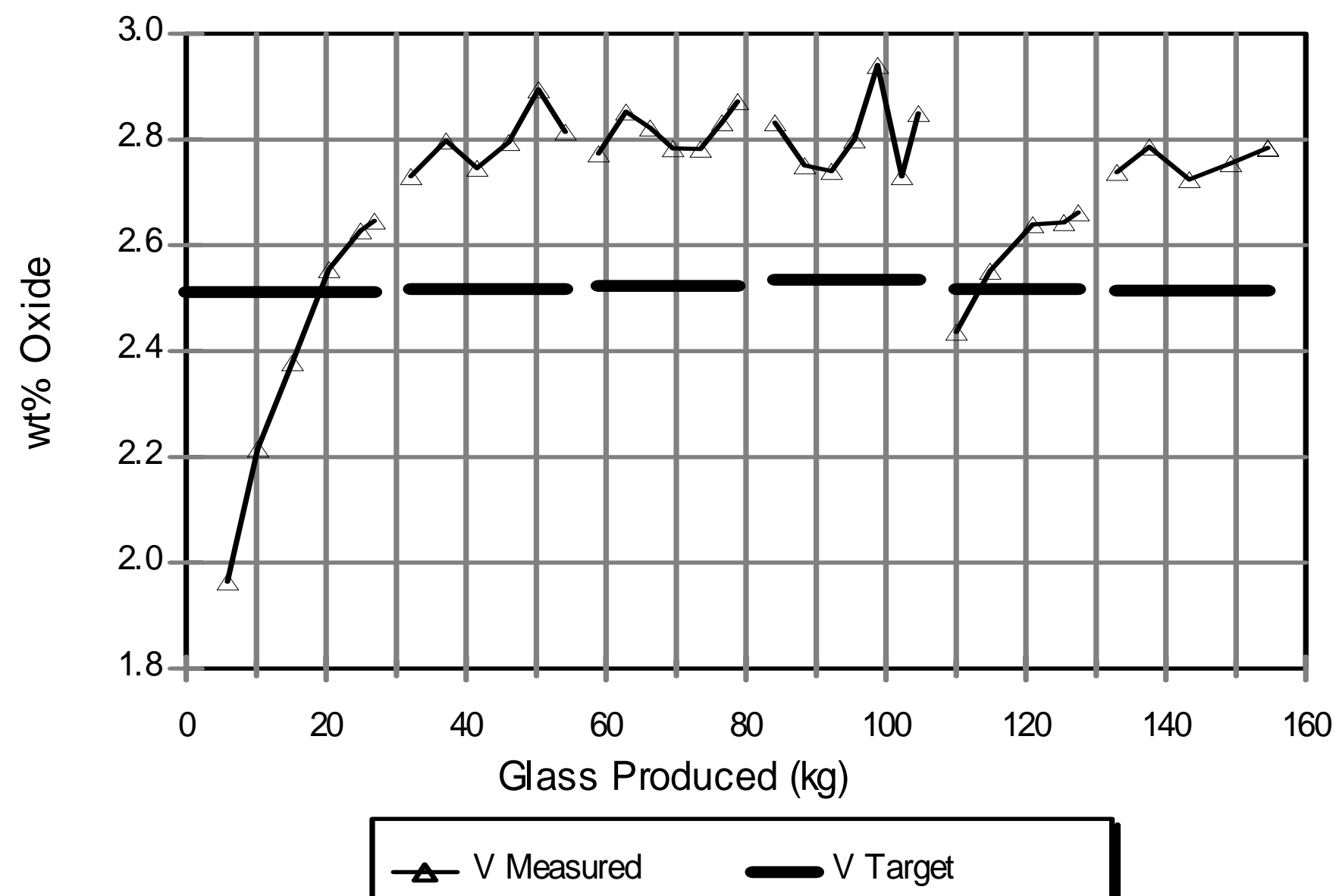

Figure 4.7.b. XRF analysis of vanadium in DM10 product glasses from Test F. Note: Other testing and therefore melt pool turnover occurred between the fourth and fifth test segment shown.

(See Table 4.2 and Section 4.1 for details of composition analysis) 


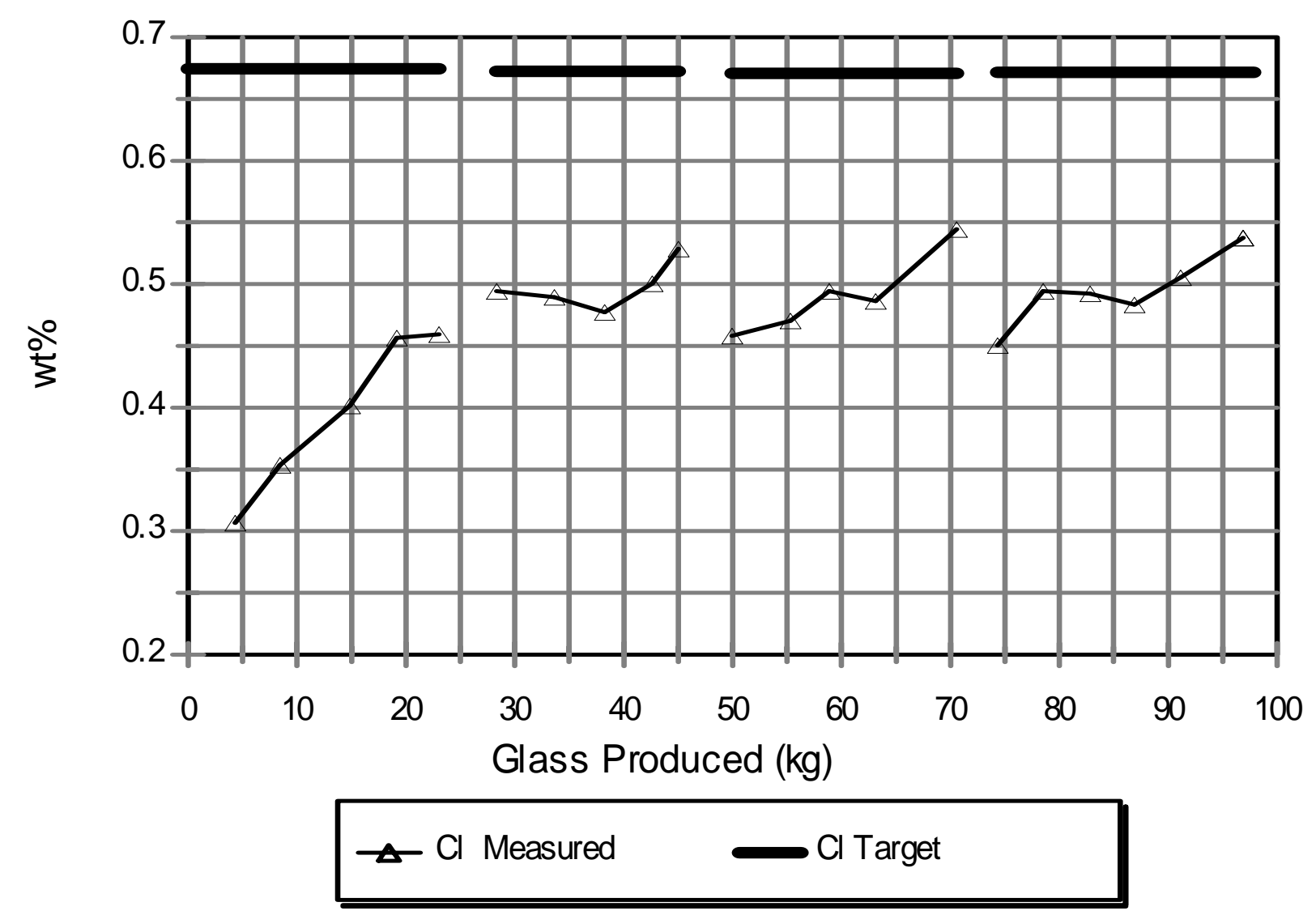

Figure 4.8.a. XRF analysis of chlorine in DM10 product glasses from Test A. (See Table 4.2 and Section 4.1 for details of composition analysis) 


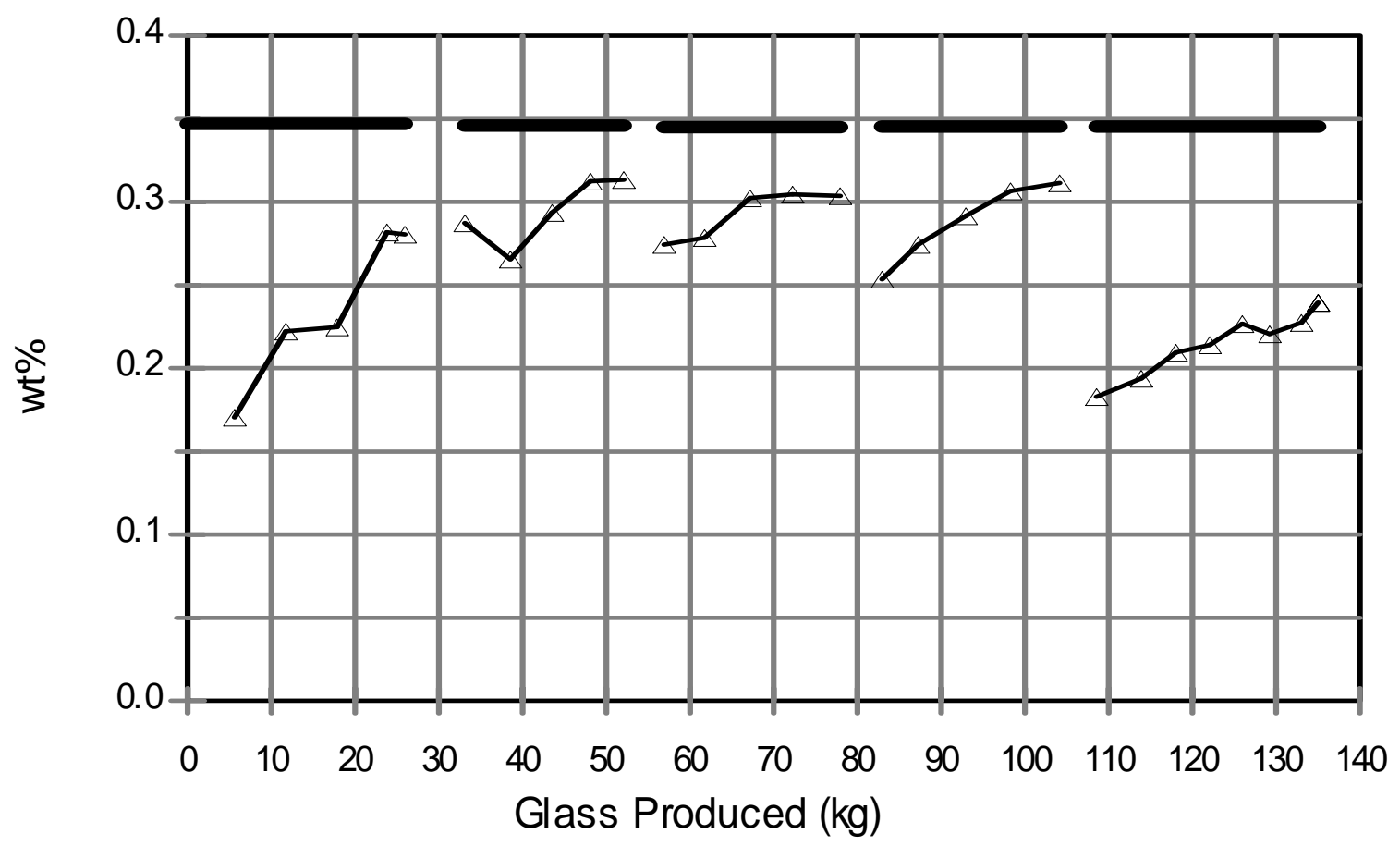

$$
\triangle \mathrm{Cl} \text { Measured } \quad \mathrm{Cl} \text { Target }
$$

Figure 4.8.b. XRF analysis of chlorine in DM10 product glasses from Test D. Note: Other testing and therefore melt pool turnover occurred between the fourth and fifth test segment shown.

(See Table 4.2 and Section 4.1 for details of composition analysis) 


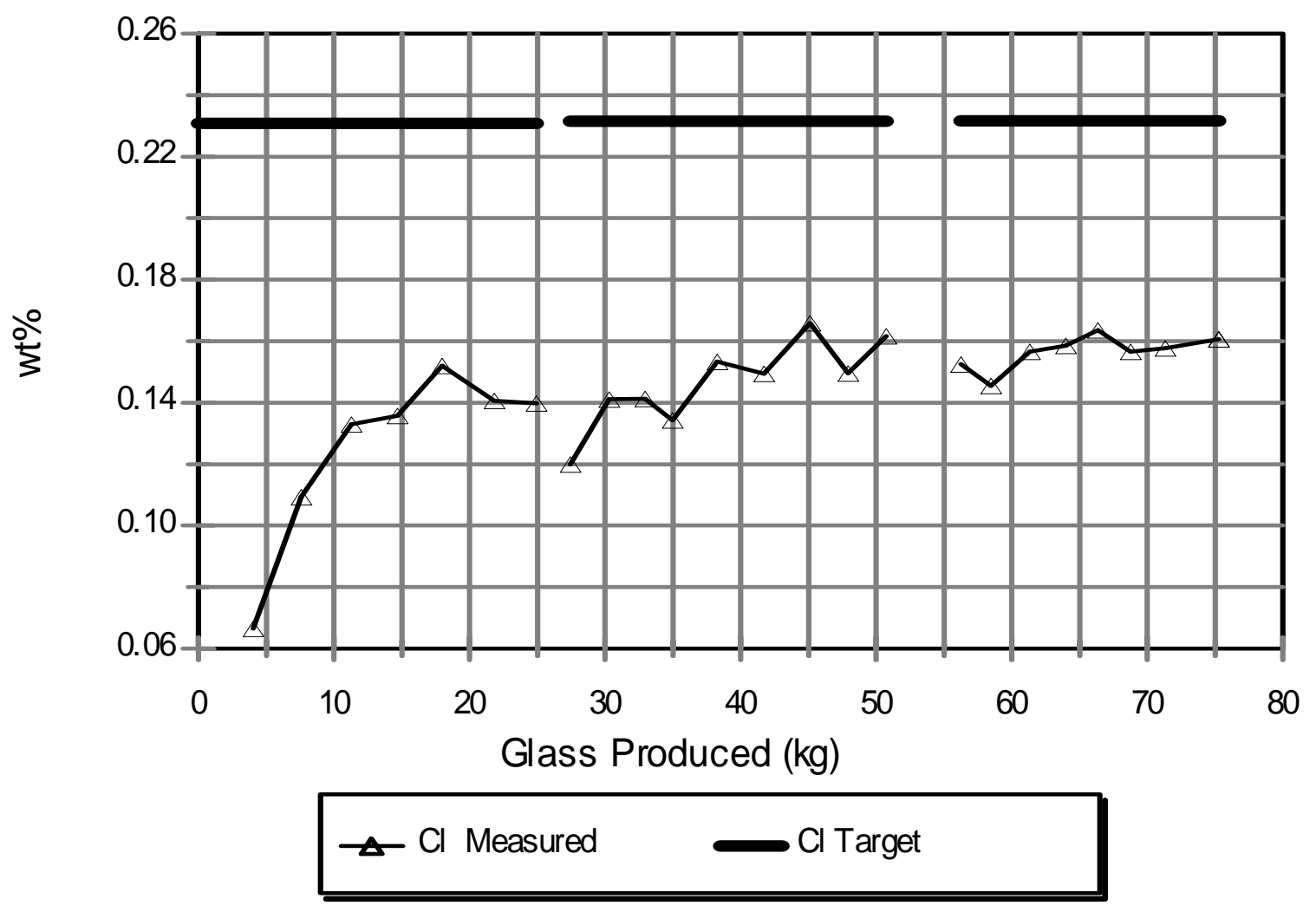

Figure 4.8.c. XRF analysis of chlorine in DM10 product glasses from Test G. (See Table 4.2 and Section 4.1 for details of composition analysis) 


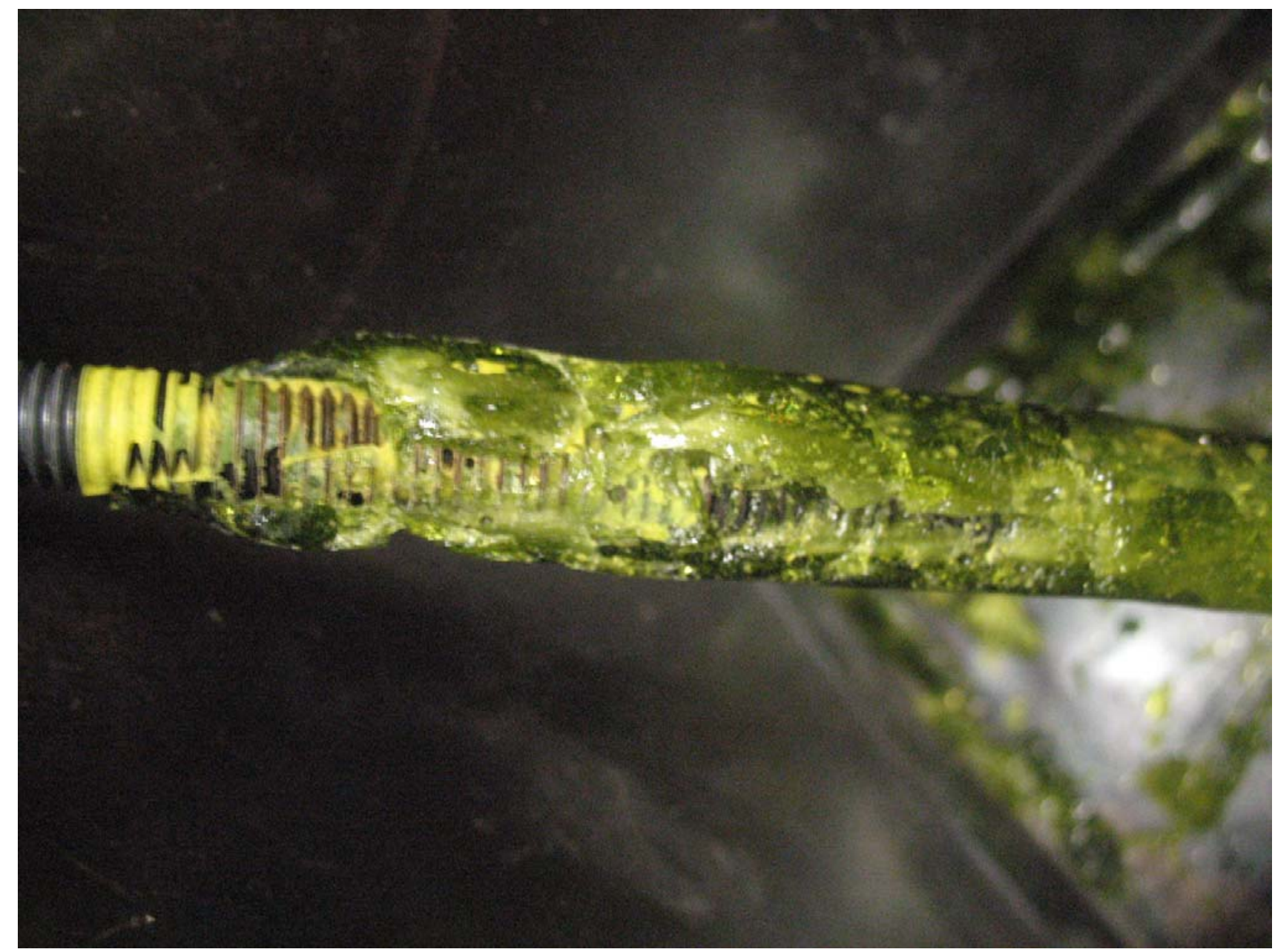

Figure 4.9. Secondary sulfur phases on dip sample Z10-D-10C from the end of Test A4. 


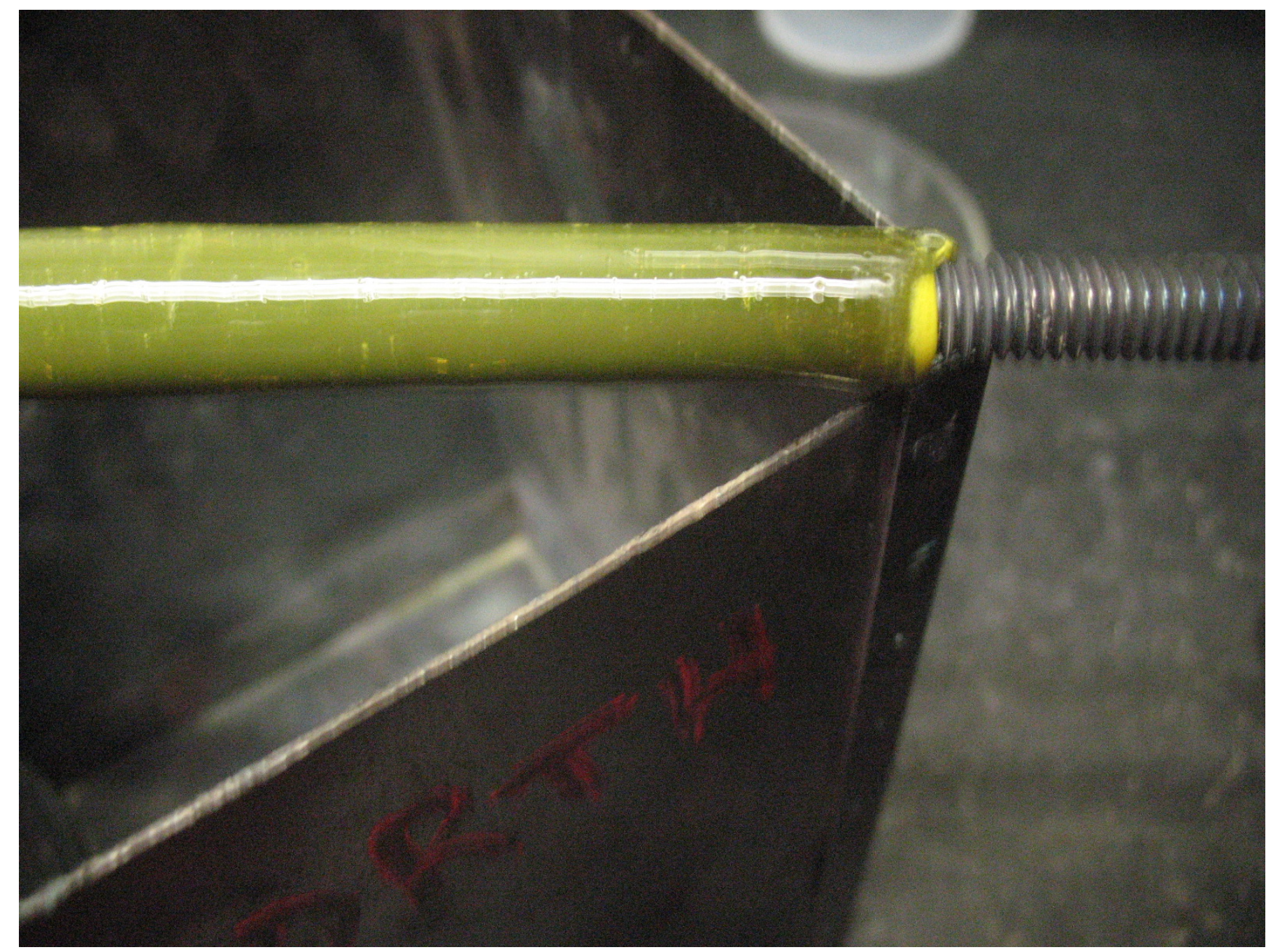

Figure 4.10. Secondary sulfur phases on dip sample Z10-D-53A from the end of Test D3 


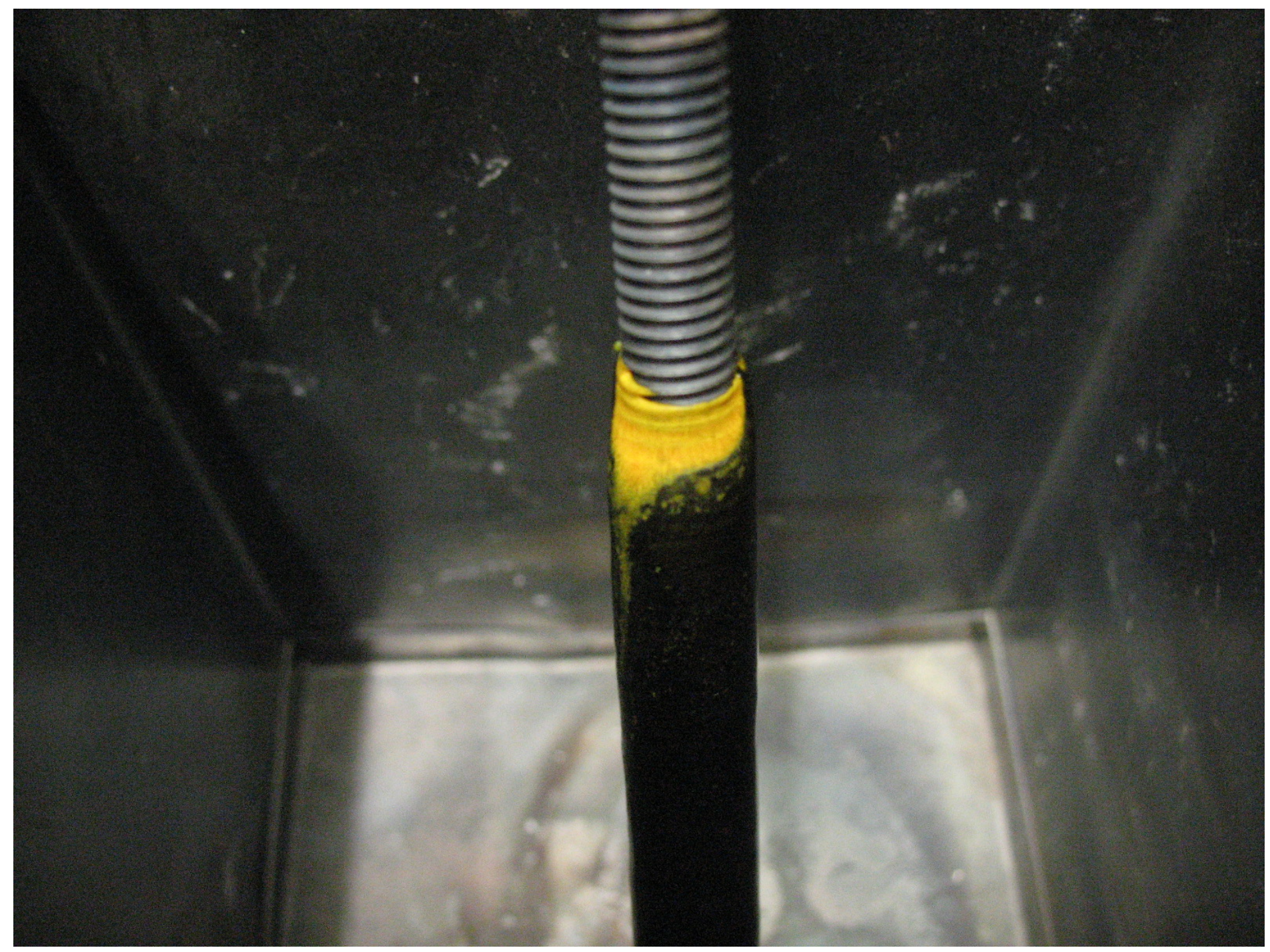

Figure 4.11. Secondary sulfur phases on dip sample Z10-D-90E from the end of Test D2. 


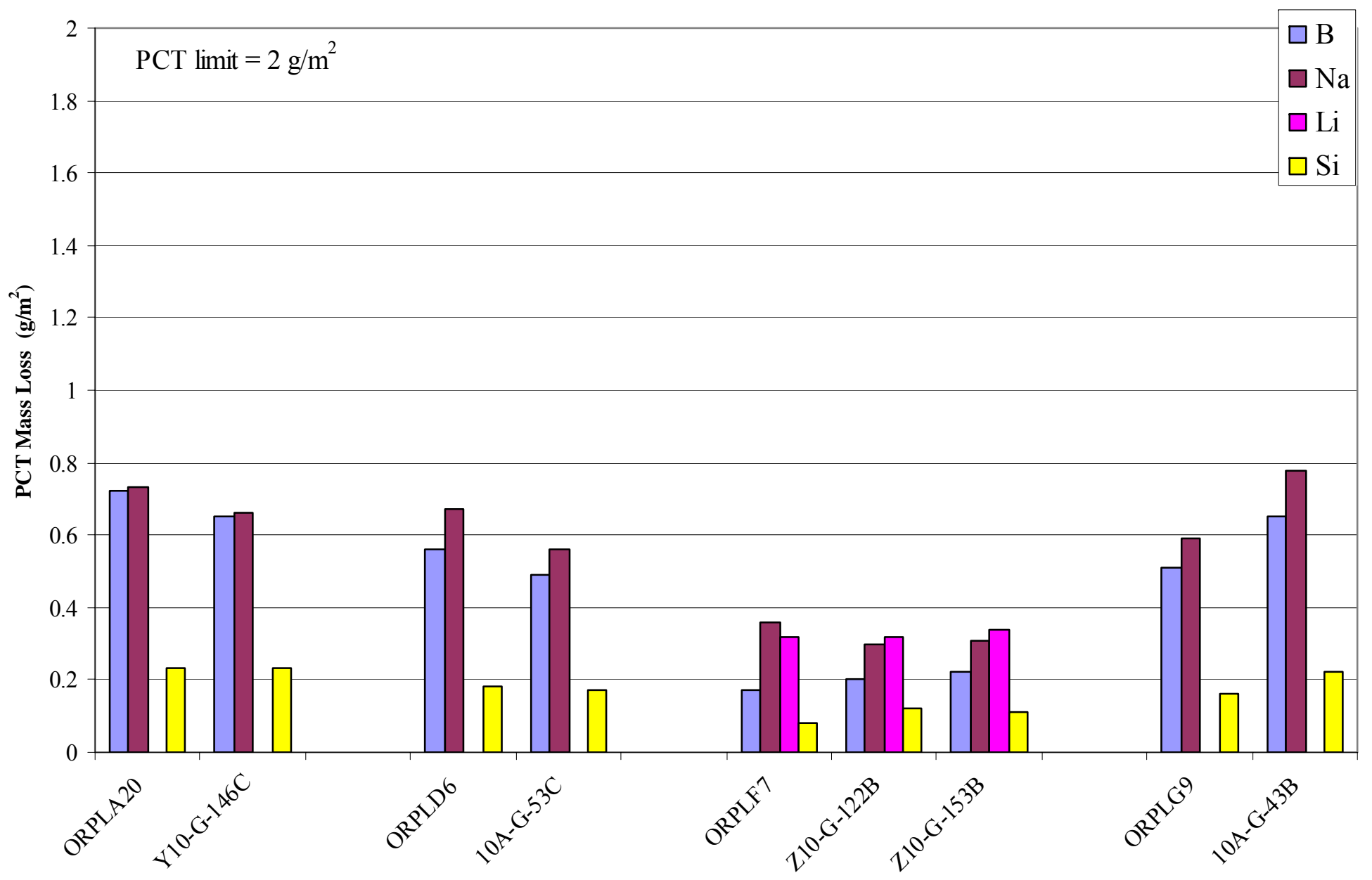

Figure 4.12. Comparison of PCT results for ORP crucible and melter glasses.

(Percent relative standard deviations (\%RSDs) of PCT measurements estimated from round robin testing are PCT-B 27, PCT-Na 21, and PCT-Si 15 [66]) 


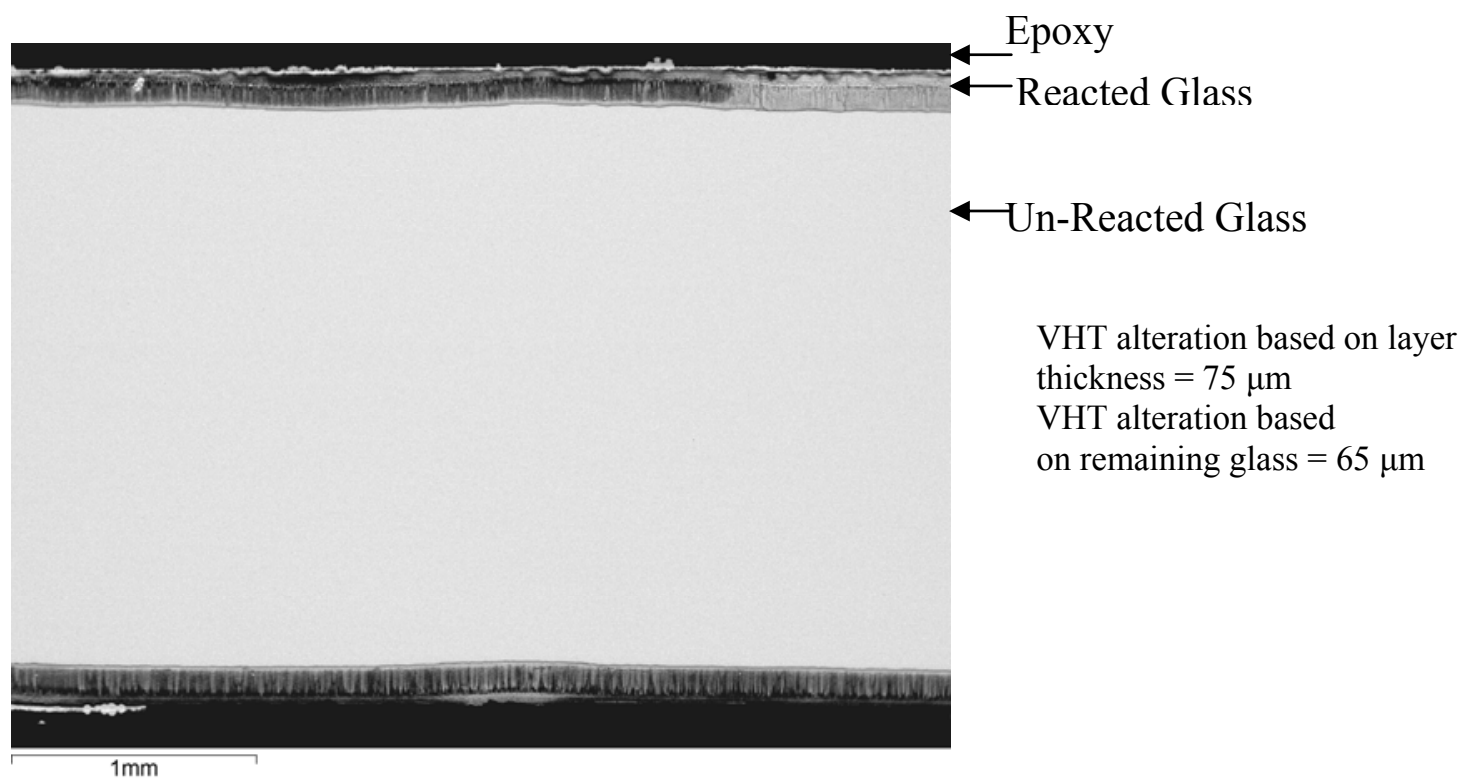

Figure 4.13 a. SEM image of cross section of crucible glass ORPLA20 after VHT.

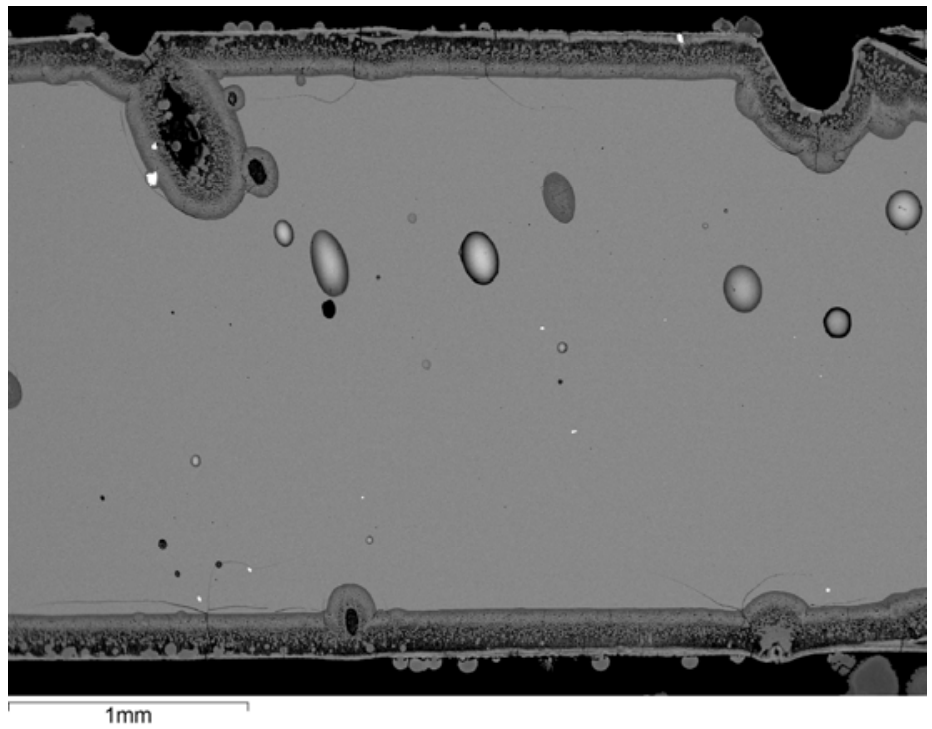

VHT alteration based on layer thickness $=190 \mu \mathrm{m}$ VHT alteration based on remaining glass $=140 \mu \mathrm{m}$

Figure 4.13 b. SEM image of cross section of DM10 melter glass Y10-G-146C after VHT.

Figure 4.13. Comparison of VHT coupons for glass formulation ORPLA20. 


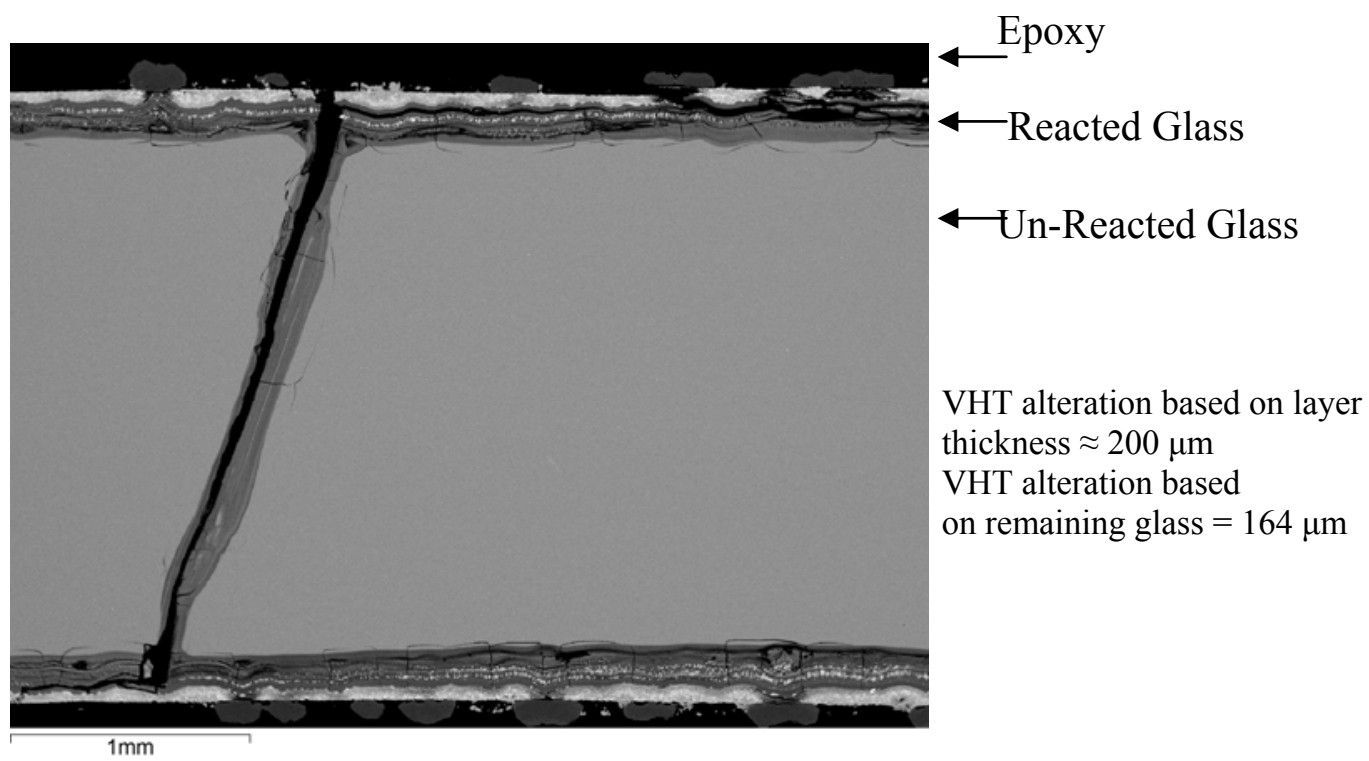

Figure 4.14 a. SEM image of cross section of crucible glass ORPLD6 after VHT.

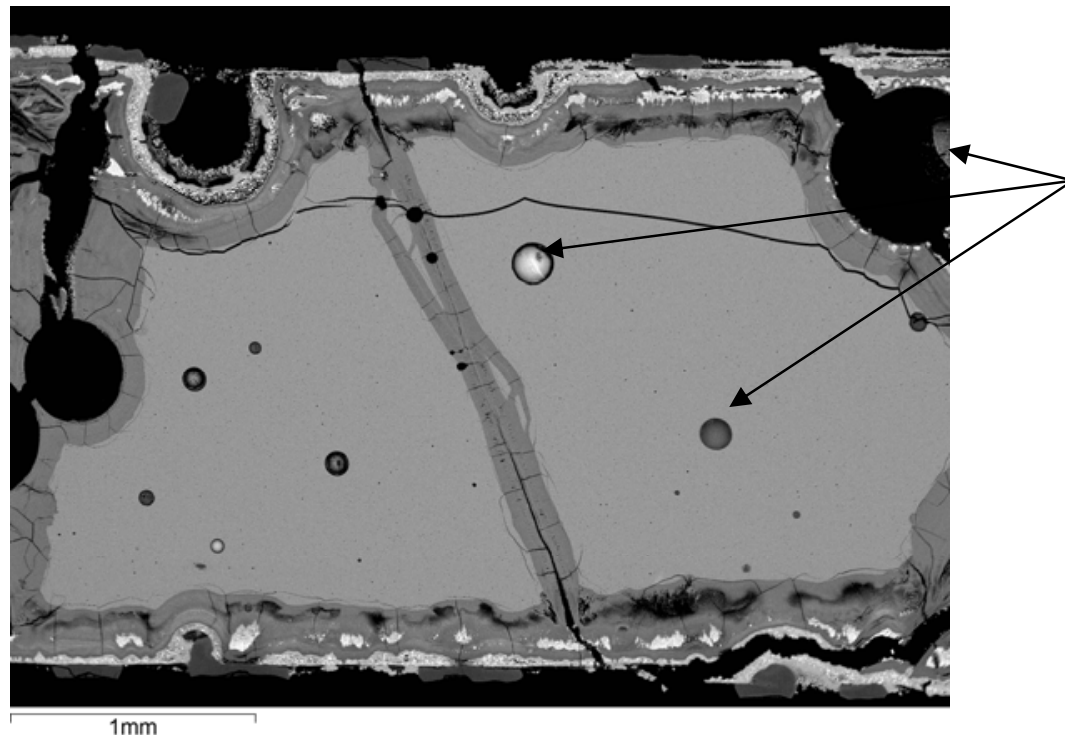

Melter glass contains bubbles and fractures

VHT alteration based on layer thickness $=300 \mu \mathrm{m}$ VHT alteration based on remaining glass $=246 \mu \mathrm{m}$

Figure 4.14 b. SEM image of cross section of DM10 melter glass 10A-G-53C after VHT.

Figure 4.14. Comparison of VHT coupons for glass formulation ORPLD6. 
Glass Formulation Development and DM10 Melter Testing with ORP LAW Glasses Final Report, VSL-09R1510-2, Rev. 0

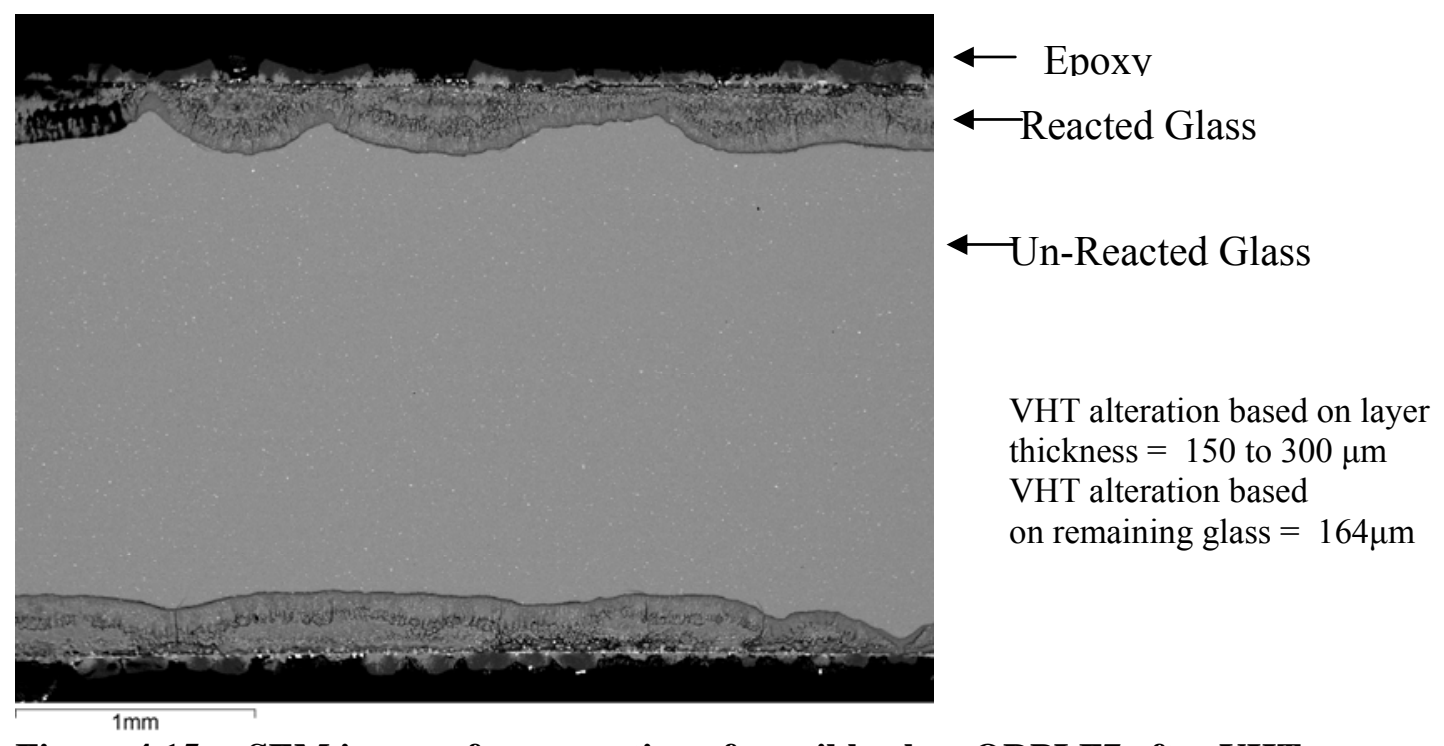

Figure 4.15 a. SEM image of cross section of crucible glass ORPLF7 after VHT.

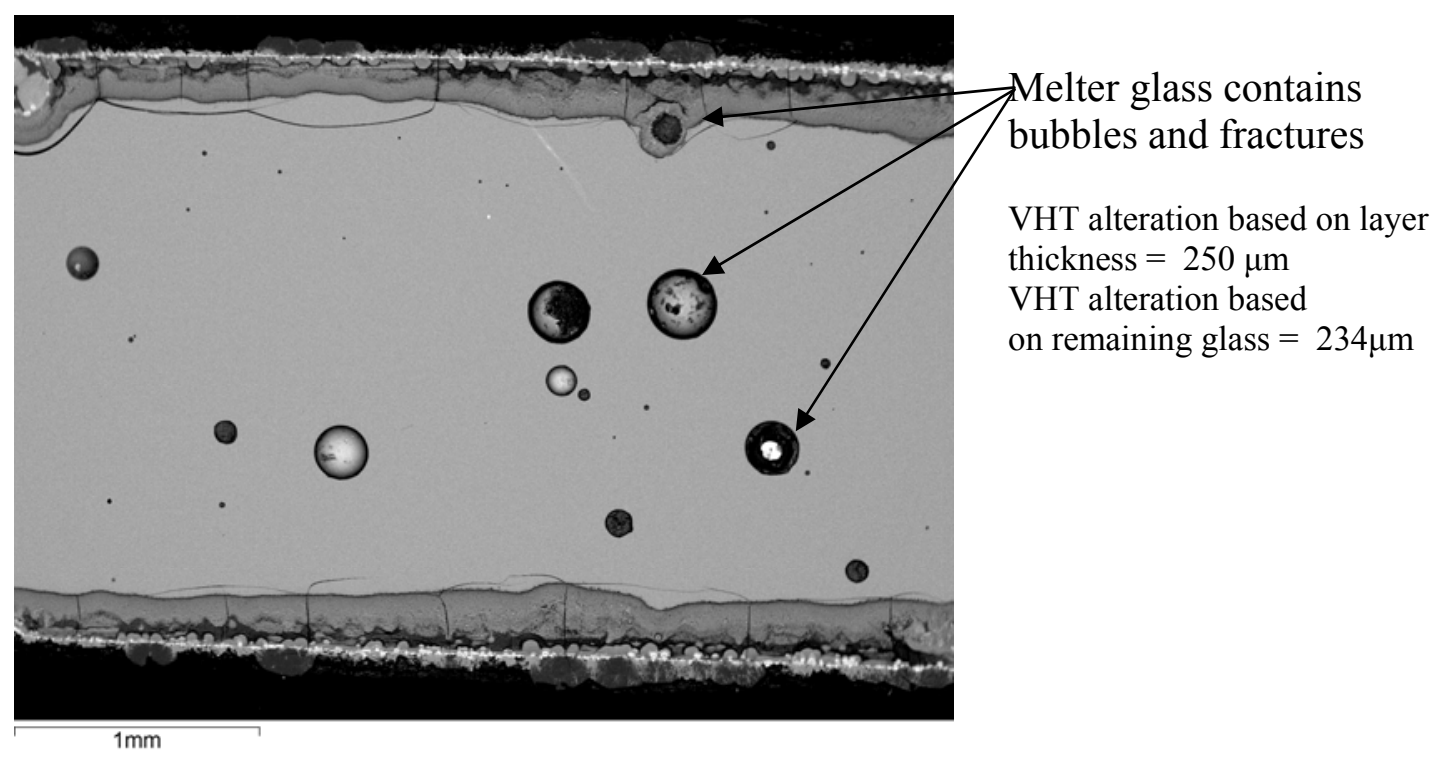

Figure 4.15 b. SEM image of cross section of DM10 melter glass Z10-G-153B after VHT.

Figure 4.15. Comparison of VHT coupons for glass formulation ORPLF7. 
The Catholic University of America Vitreous State Laboratory
Glass Formulation Development and DM10 Melter Testing with ORP LAW Glasses Final Report, VSL-09R1510-2, Rev. 0

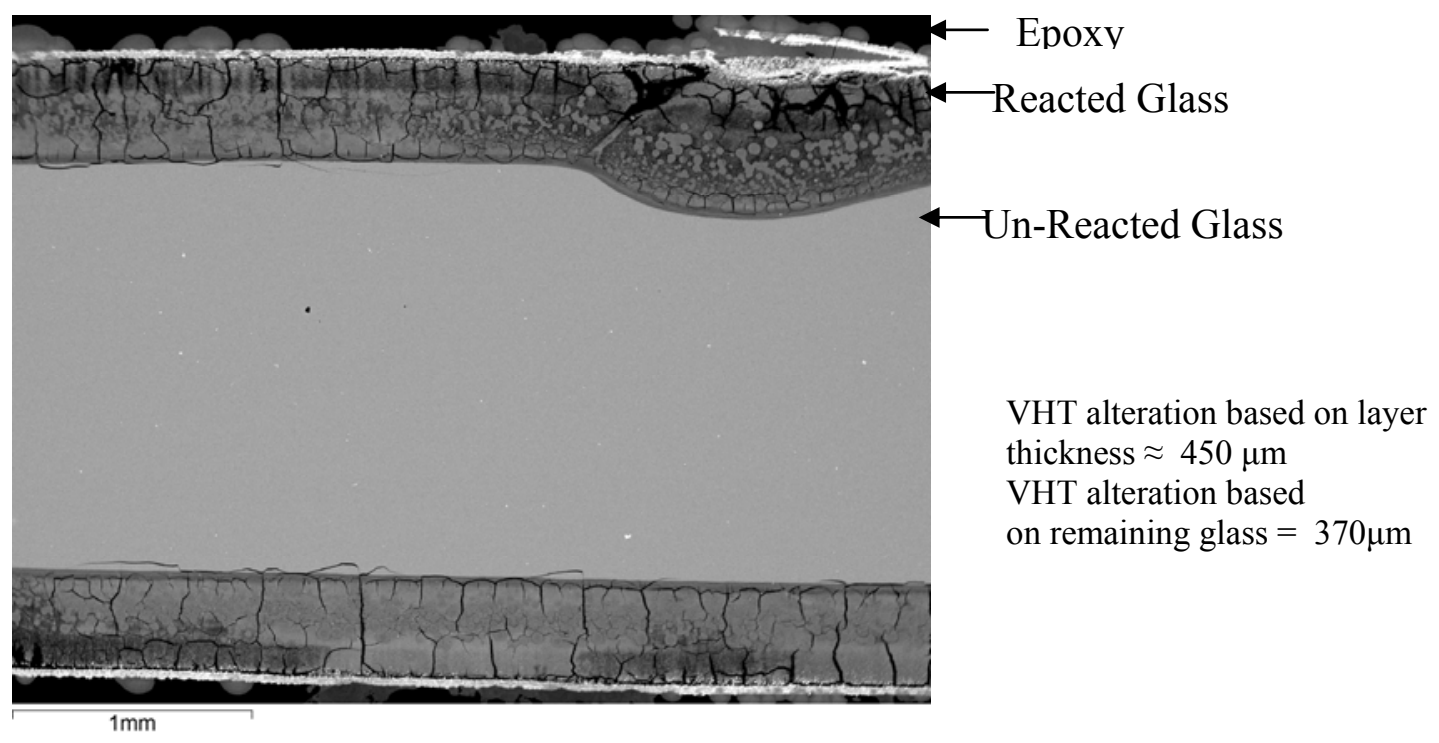

Figure 4.16 a. SEM image of cross section of crucible glass ORPLG9 after VHT.

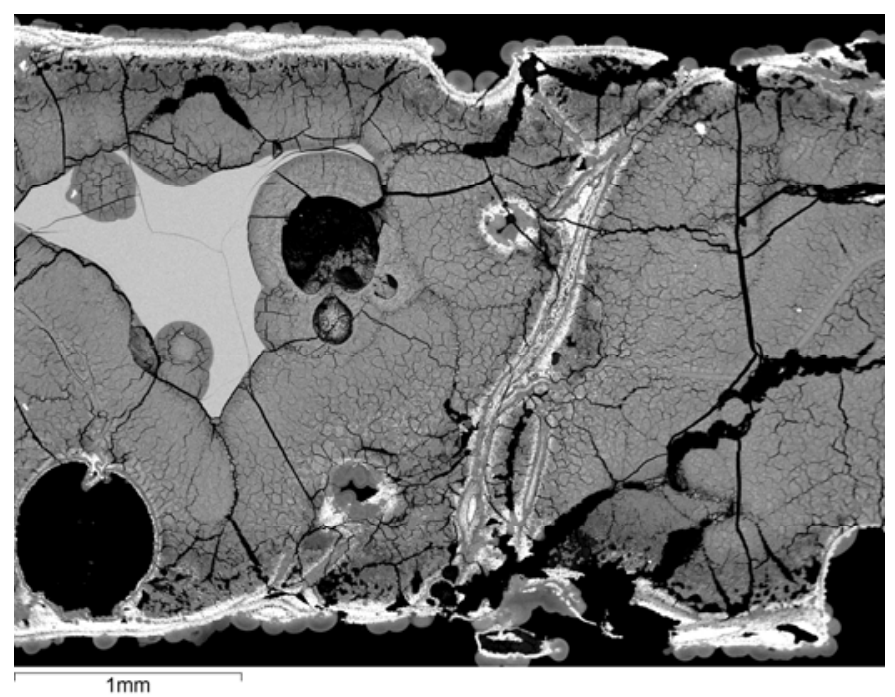

Melter glass contains bubbles and many fractures

VHT coupon fully reacted Layer thickness $\approx 1200 \mu \mathrm{m}$

Figure 4.16 b. SEM image of cross section of DM10 melter glass 10A-G-53C after VHT.

Figure 4.16. Comparison of VHT coupons for glass formulation ORPLG9. 


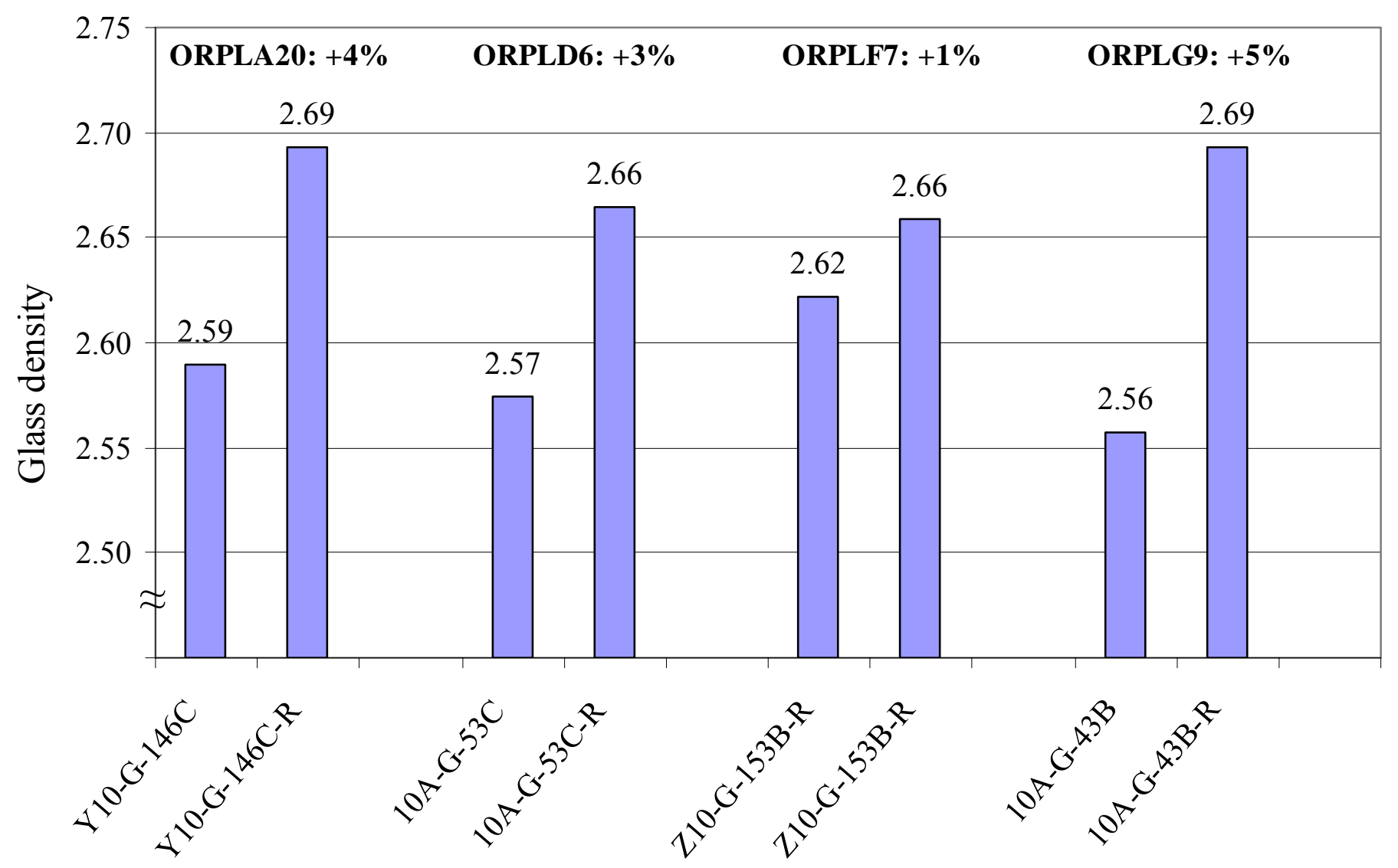

Figure 4.17. ORP LAW melter glass densities: comparison of glass as-collected from the DM10 melter and after remelting. (Reported densities are averages of three measurements with percent relative standard deviation (\%RSD) of $<0.4$ ) 


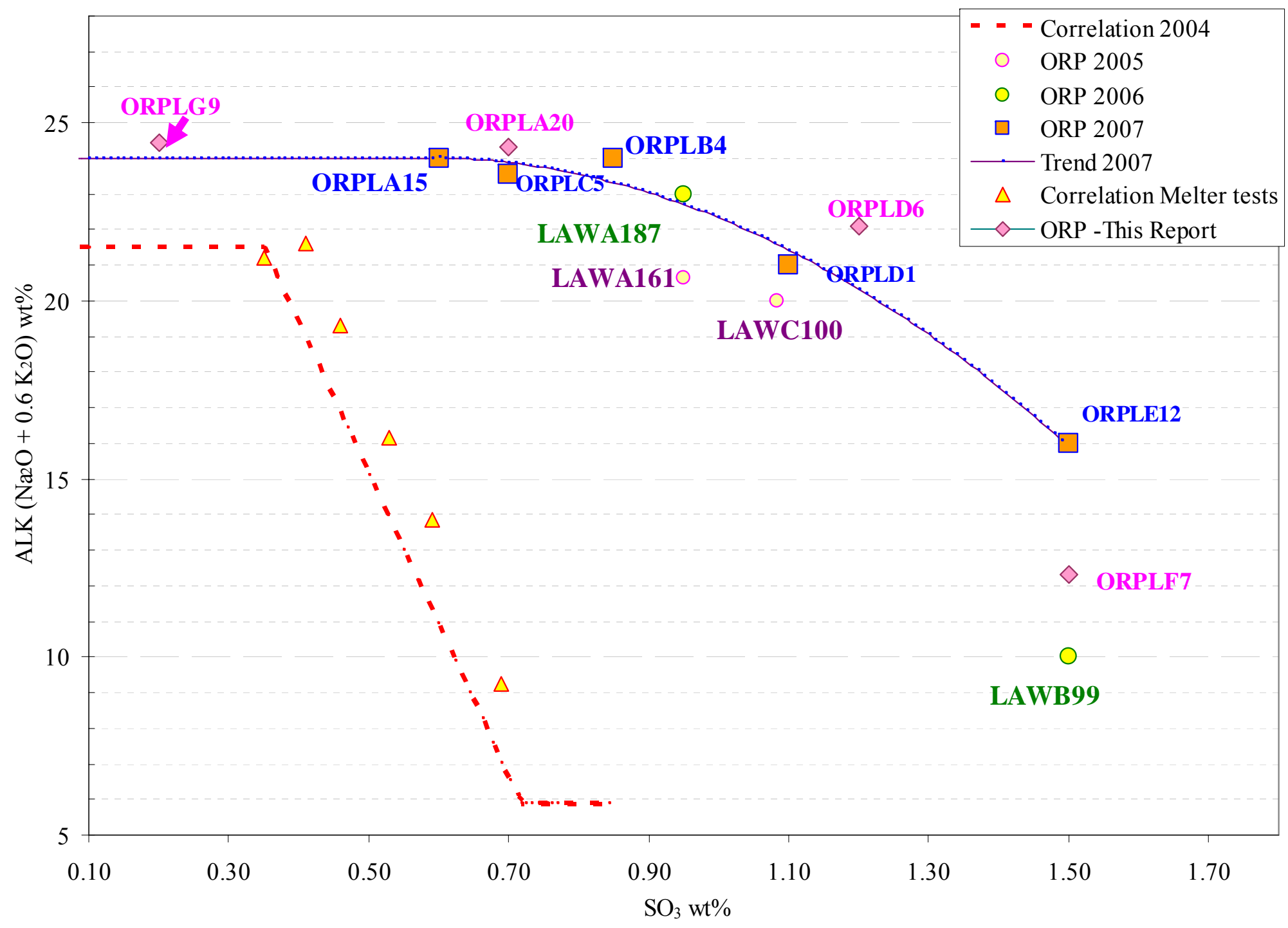

Figure 5.1. Overview of $\mathrm{Na}_{2} \mathrm{O}$ and $\mathrm{SO}_{3}$ loadings for WTP and ORP glasses. 


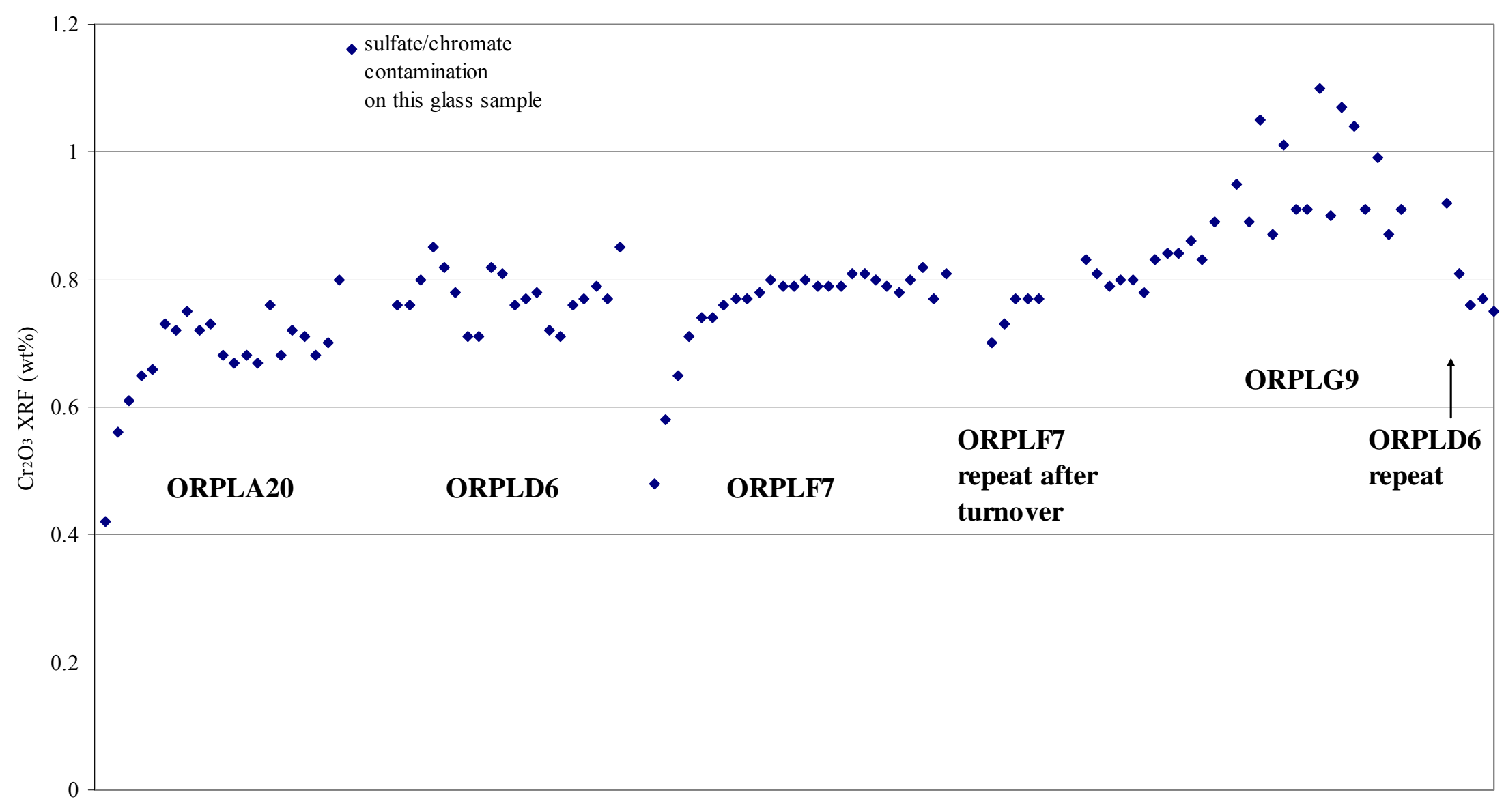

Figure 5.2 Evolution of $\mathrm{Cr}_{2} \mathrm{O}_{3}$ content (XRF wt\%) in the glasses collected from DM-10 testing. 